MARIA DE LURDES SAMPAIO • GONÇALO VILAS-BOAS (OrgS.)

\title{
Cherchez les femmes Estudos de Literatura Policial
}

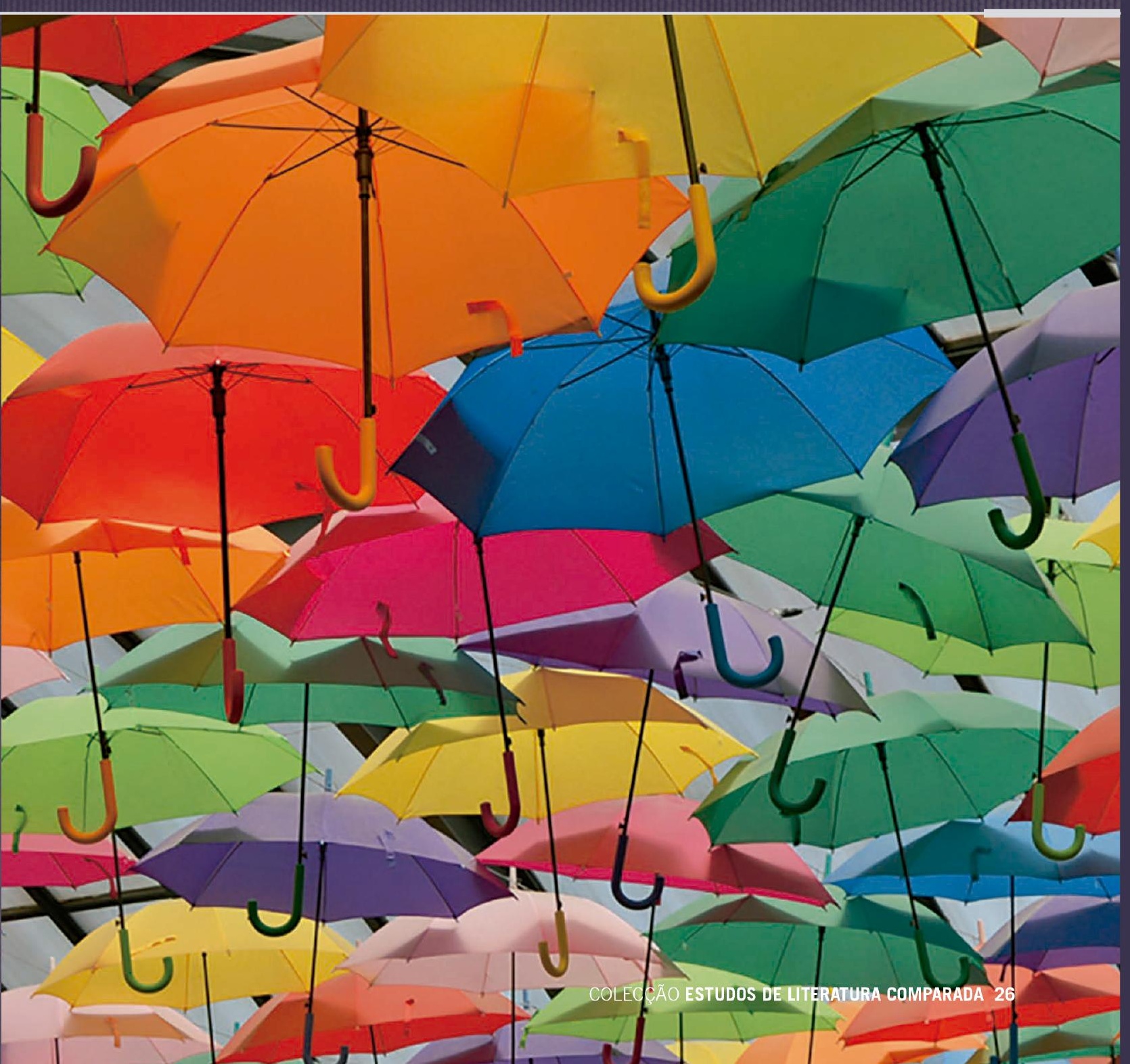


Cherchez les Femmes:

estudos de literatura policial 
Título: Cherchez les Femmes: estudos de literatura policial

Autores: Maria de Lurdes Sampaio e Gonçalo Vilas-Boas

Capa: Departamento gráfico | Edições Afrontamento

Edição: Instituto de Literatura Comparada Margarida Losa (FLUP) e Edições Afrontamento

Conceção gráfica: Departamento gráfico / Edições Afrontamento

Coleção: Estudos de Literatura Comparada, 26

N. ${ }^{\circ}$ de edição: ????

ISBN: 978-972-36-1815-0

Depósito legal: 471005/20

Execução gráfica: Rainho \& Neves, Lda./ Santa Maria da Feira

geral@rainhoeneves.pt

Distribuição: Companhia das Artes - Livros e Distribuição, Lda.

comercial@companhiadasartes.pt

(C) Autor, Edições Afrontamento e Instituto de Literatura Comparada Margarida Losa (FLUP)

Edições Afrontamento, Lda.

Rua Costa Cabral, 859, 4200-225 Porto

www.edicoesafrontamento.pt

comercial@edicoesafrontamento.pt

Instituto de Literatura Comparada Margarida Losa (FLUP)

www.ilcml.com

Esta publicação foi desenvolvida no âmbito do Instituto de Literatura Comparada, Unidade I\&D financiada por Fundos Nacionais através da FCT - Fundação para a Ciência e para a Tecnologia (UIDP/00500/2020). 


\section{Cherchez les Femmes: estudos de literatura policial}

Maria de Lurdes Sampaio e Gonçalo Vilas-Boas 



\section{Sumário}

Prefácio, Maria de Lurdes Sampaio e Gonçalo Vilas-Boas

Introdução, Gonçalo Vilas-Boas e Maria de Lurdes Sampaio

\section{I O CASO PORTUGUÊS}

No rasto das mulheres na ficção policial em Portugal: fórmulas e singularidades Maria de Lurdes Sampaio

II

\section{OUTROS QUADRANTES EUROPEUS}

A narrativa criminal escrita por mulheres em Espanha (1975-2018)

Elena Losada Soler

Herland, a rede de autoras feministas de romances de detectives em língua alemã Kirsten Reimers

A history of Swedish women crime writers - from the Golden age until the 2010s Sara Kärrholm

Autoras gregas de textos policiais

Virginia Spyratou

III

POR VÁRIOS CONTINENTES

Tana French's Crime Novels: Dublin After History 
As deslocações da visão ou a coscuvilhice do olhar alucinado: Quando o observador se move à distância

Carlos J. F. Jorge

«To play a Fool»: uma narrativa feminocêntrica por Laurie R. King

Duarte Pinheiro

Perspectivas femininas no policial suíço: Verena Wyss, Sabina Altermatt

e Petra Ivanov

Gonçalo Vilas-Boas

Uta-Maria Heim. Uma breve apresentação de uma destemida escritora experimental

Jochen Vogt

Batya Gur e os mistérios dos humanos

Maria João Falcão

Patrícia Melo e a reconfiguração do policial brasileiro

Mariana Cepeda

Détection, Damage, and Resistance: On Sara Gran's Claire DeWitt's novels

Paulo de Medeiros

Notas biobliográficas sobre os/as colaboradores/as 


\section{Prefácio}

Maria de Lurdes Sampaio e Gonçalo Vilas Boas

O volume que agora publicamos, com o título 'Cherchez les Femmes': estudos de literatura policial, é o último de uma trilogia de ensaios dedicados a suprir uma das lacunas no panorama literário português: a ausência de uma tradição de reflexão crítica sobre um género de grande popularidade em todo o mundo ao longo dos séculos XX e XXI. 0 primeiro volume desta trilogia, Crime, Detecção e Castigo. Estudos sobre literatura policial (2001), reunia os textos apresentados no colóquio promovido pelo Instituto de Literatura Comparada Margarida Losa (ILCML) no ano de 2000. O segundo volume, Ficção Policial: antologia de ensaios teórico-críticos, publicado em 2012, tinha como objetivo fundamental dar a conhecer, em tradução, ensaios canónicos de autores estrangeiros (de G. K. Chesterton a Raymond Chandler, entre muitos outros) de referência incontornável na abordagem das subespécies do género policial ou no estudo particularizante de autores e obras. Relembrávamos no «Prefácio» que o livro de Ernest Mandel, Delightful Murder. A Social History of Crime (1984), traduzido para português com o título Cadáveres Esquisitos. Uma história social do romance policial (1993) continuava a ser, na primeira década do séc. XXI, o livro mais relevante e mais conhecido em Portugal sobre literatura policial. Com a inclusão do ensaio de Priscilla L. Walton e Manina Jones, «Sim ou não? A problemática da narrativa de detecção feminina» (1999), procurámos dar conta da emergência de detetives mulheres na ficção policial e da importância que as obras policiais de autoria feminina adquiriram, um pouco por toda a parte, a partir dos anos 1980. Publicado que foi esse segundo volume, com as limitações que uma antologia e as traduções sempre implicam, tornou-se evidente que um terceiro se seguiria e que ele teria de ser exclusivamente dedicado à presença feminina na literatura policial (autoria, detetives, perspetivas).

A contrariar a anunciada morte do romance policial (e do romance em geral), o boom do policial nórdico surpreendeu leitores e estudiosos do género, habituados a associá-lo a horizontes anglo-americanos. As razões da popularidade dessa produção continuam a ser 
um tanto obscuras, mas não há dúvidas de que um excelente planeamento editorial visando o sucesso é já parte da resposta. Para lá disso, poderíamos apontar o modo como o policial explorou, nessas paragens, o cruzamento com as fórmulas da literatura de viagens (enfatizando o locus criminalis), do gótico, da literatura sensacionalista, e/ou do romance de costumes. Ao sucesso dos autores nórdicos acresce o contributo vindo da América Latina, com autores como Rubem Fonseca e Patrícia Melo (Brasil), Élmer Mendoza (i.e., a narcoliteratura vinda do México) ou ainda as brilhantes e inclassificáveis obras de um Roberto Bolano (Chile), com os seus intelectuais-detetives. E há o papel profundamente transformador, um pouco por todo o lado, de obras de autoria feminina, muitas das quais em correlação com as diferentes correntes do feminismo. Como muitos investigadores têm demonstrado (de Sally Munt a Peter Messent), as mulheres têm tido um papel decisivo na revitalização do género policial: pela criação de detetives mulheres, pela produção de um discurso invertido (no sentido foucauldiano), pelo poder de agenciamento que conferem a figuras femininas, pelo ensaio de diferentes formas de (re)negociação com convenções do género e com o público e, não menos importante, por um impressionante alargamento temático das suas obras (questões ecológicas, étnicas, questões de género), entre muitas outras razões que poderíamos elencar.

O propósito inicial de organização de um volume de ensaios que fizesse uma cartografia mínima da produção policial no feminino na Europa, com ensaios dedicados a um conjunto diversificado de países (dos «centrais» a periféricos), não pôde ser concretizado. Assim, optámos por uma antologia aberta de ensaios que preenchessem pelo menos dois requisitos: i) incidência em obras de autoria feminina e/ou em obras de escritores ou escritoras, que tivessem como protagonistas detetives mulheres; ii) incidência em obras produzidas a partir dos anos de 1980, tendo em conta que é a partir dessa altura que assistimos a uma produção significativa de romances policiais que questionam a hegemonia e as convenções das obras de autoria masculina.

O resultado é um conjunto bastante eclético de estudos, sendo a maioria dedicado a autoras singulares, pois quer as visões de conjunto quer as abordagens mais teóricas são difíceis, quando não existem estudos prévios das obras e das respetivas autoras. Há também, nestes ensaios, variações conceptuais e terminológicas ("detective fiction» vs "crime fiction», por exemplo) que têm a sua razão de ser e que têm nos próprios ensaios a sua justificação e explicação.

Como Maurizio Ascari escreveu no ensaio «From Enigmas to Emotions: The Twentieth-Century Canonization of Crime Fiction» (2013), o policial (no masculino e/ou no feminino) não pára de nos surpreender: 
Crime fiction continues to expand, thanks to an unceasing hybridization of forms whose results are unforeseeable, and those who study it can only observe - with a combination of enthusiasm and dizziness - that this literary landscape changes before we understand its rules. After all, knowing that the object of our critical inquiries is a living cultural entity amply compensates us for unsuing lack of certainties. (Ascari 2013: 17)

Estamos convictos de que os ensaios que se seguem ajudarão a compreender muitos aspetos dessa paisagem em mutação e que eles darão um contributo importante para a realização de trabalhos académicos e não académicos neste domínio.

Para finalizar, gostaríamos de deixar uma palavra especial de gratidão aos participantes neste volume pela sua disponibilidade para colaborarem na nossa iniciativa e partilharem connosco os seus saberes e leituras. E o nosso reconhecimento à Dr. ${ }^{\underline{a}}$ Lurdes Gonçalves por todo o apoio prestado na organização deste livro. 

menos afetado, sobretudo se (re)conhecer o espaço real empírico correspondente ao espaço ficcional.

Alguns detetives tornam-se comentadores cínicos da sociedade em que se inserem. Podem resolver um crime, restabelecer a ordem que foi perturbada pelo assassínio, mas o mundo do crime, e a sociedade corrupta, esses, continuam impunes. Isto é, o verdadeiro culpado, em última instância, é a sociedade, que cria as condições para que o crime possa acontecer. Como tem sido referido por alguns críticos e autores (Simenon, por exemplo), todos nós somos passíveis de nos tornarmos criminosos.

Se até agora o mundo do policial era dominado por homens, com algumas exceções como as britânicas Agatha Christie, Dorothy Sayers, ou a norte-americana Patricia Highsmith, a situação alterou-se profundamente e hoje temos várias autoras que criam mulheres detetives para resolverem o que antes era atribuído quase exclusivamente aos homens. Uma obra de referência a assinalar essa diferença é o romance de P.D. James An Unsuitable Job for a Woman, de 1972 (Trabalho Impróprio para uma Mulher). Trata-se, antes de mais, de um olhar diferente, já que o mundo do crime é o mesmo. Homens e mulheres não agem necessariamente de modo igual perante os mesmos fenómenos e não têm sempre os mesmos métodos de investigação e de liderança.

O género foi durante décadas dominado por autores masculinos, pois o ofício de detetive não era considerado apto para as mulheres por causa da ênfase nas faculdades de raciocínio ou da sua dureza e violência. As mulheres não tinham grande espaço fora do lar e não foram muitas as que, ao longo do século $\mathrm{XX}$, conquistaram lugares importantes. Com a evolução dos direitos das mulheres, a situação foi-se modificando lentamente. Note-se que o público, masculino e feminino, tinha continuado a dar preferência aos heróis masculinos. Mas foi sobretudo a partir dos anos 80 do século XX que as mulheres conquistaram lugares de relevância na deteção; primeiro, como «private eye», depois, integradas em diferentes corpos da polícia, sendo, por vezes, investidas de papéis de chefia no grupo. Este facto representou uma quebra no domínio da perspetiva masculina, surgindo diferentes subgéneros e combinatórias diversificadas: a) há um homem (dominante) e uma mulher; b) há uma mulher (dominante) e um homem; c) há uma mulher solitária; d) há duas mulheres; e) há um grupo de homens liderados por uma mulher. E aqui começam a surgir as margens, a tornarem-se visíveis romances que lidam com tabus, como os «policiais lésbicos», estes mais interessados no relacionamento entre as pessoas do que na trama pro- 
priamente dita, mas também policiais onde a detetive negra é a dominante, ou outros que tematizam questões étnicas. Deste modo, destabiliza-se o modelo tradicional, binário, surgindo novas narrativas a partir de lugares marginais, seja de género, de raça, de cultura, enfim, novos olhares, acompanhando as modificações do mundo, sempre em mudança.

Novo neste olhar feminino é a luta da mulher pelo seu reconhecimento e competência num meio tradicionalmente masculino, a sua afirmação no meio da deteção, acrescidos dos problemas decorrentes da tensão entre a profissão e a família, sobretudo quando ligados à maternidade. Assim, as mulheres detetives têm, no mínimo, dois campos pessoais de luta: no emprego e em casa.

A acompanhar esta evolução, assistimos a um crescente interesse por subgéneros onde a mulher está muito presente, quer na autoria quer no papel de personagens importantes: policiais à volta do mundo das finanças, das academias, da história, de perfis humanistas e muitos outros.

Nos ensaios reunidos neste volume pretende-se olhar para a história de algumas literaturas «de crime» (ou «policiais») e para algumas escritoras de diferentes países e zonas linguísticas, mas também de escritores onde a figuração das mulheres seja relevante. Em nenhuma zona linguística domina um subgénero. A escrita é individual, ainda que se possam traçar alguns traços distintivos entre zonas linguísticas diversas, incluindo a inserção no panorama linguístico respetivo.

A antologia 'Cherchez les Femmes: estudos de literatura policial' subdivide-se em três partes: a parte I intitula-se O CASO PORTUGUÊS. No estudo «No rasto das mulheres na ficção policial em Portugal: fórmulas e singularidades», Maria de Lurdes Sampaio procede a um inventário de escritoras que escreveram romances policiais ou «quase-policiais», e de autores masculinos que criaram detetives femininas, procurando articular uma visão panorâmica com a análise interpretativa aprofundada de algumas obras selecionadas. O extenso estudo histórico-crítico elaborado visa, assim, dar a conhecer e sistematizar um corpus de narrativas escritas por mulheres, e algumas de autoria masculina, com o objetivo de fomentar outras investigações e abordagens teóricas mais produtivas à luz de paradigmas e instrumentos concetuais contemporâneos. 
A parte II, intitulada OUTROS QUADRANTES EUROPEUS, contempla quatro ensaios de carácter mais panorâmico dedicados à Espanha, à Alemanha, à Suécia e à Grécia.

Do país vizinho apresenta-se o ensaio «A narrativa criminal por mulheres em Espanha (1975-2918)», de Elena Losada, onde se traça um panorama da narrativa criminal entre 1975 e 2018 como um fenómeno claramente pós-franquista, apesar de algumas exceções. As detetives são mulheres normais, com a dificuldade, como se vê também na escrita de outras línguas, de terem que conciliar profissão e situação familiar. A autora exemplifica com obras de várias escritoras, com destaque para as de Alicia Giménez Bartlett, com a sua comissária Petra Delgado. Elena Losada abrange, neste estudo, também a literatura escrita em catalão, basco e galego.

Kirsten Reimers traça em «Herland, a rede de autoras feministas de romances de detetives em língua alemã» uma panorâmica sobre a produção feminina de romances policiais na Alemanha, narrativas de crime e violência, nas mais diversas situações, centradas em espaços reais alemães. A autora analisa sobretudo textos de algumas autoras, como Simone Buchholz (1972-), Monika Geier (1970-), Merle Kröger (1967-) e Christine Lehmann (1958-).

Sara Kärrholm apresenta-nos em «A history of Swedish women crime writers - from the Golden age until the 2010s» um panorama do policial feminino sueco, que começou de modo relativamente lento, até ao grande salto que representou o Prémio Poloni, em 1997, contemplando somente novas escritoras de policiais. Cimentada pela divulgação do policial nórdico, as mulheres ganharam uma enorme relevância na produção sueca. Liza Marklund e Åsa Larsson foram das primeiras a terem projecção internacional, a que se seguiram autoras como Camilla Läckberg ou Mari Jungstedt e muitas outras - sem esquecer a figura de Lisbeth Salander da série Millenium iniciada por Stieg Larsson e continuada por David Lagercrantz. Não se pode definir o policial nórdico em função de um só tipo de romance, pois são muitos os subgéneros que podemos encontrar. Poderemos, contudo, dizer que muitos romances têm na base uma forte crítica social.

O policial grego tem pouca divulgação entre nós. O artigo de Virginia Spyratou, «Autoras gregas de textos policiais», dá-nos abundante informação sobre o policial grego e o seu contexto, focando obviamente escritoras. Trata-se de um fenómeno relativamente tardio, apesar de se encontrarem raízes já em 1913. Na Grécia, o policial encontrava-se ligado a edições acessíveis, quer de autoria nacional quer de traduções. Mas no século XXI dá-se uma mudança no 
I. O caso português 



\title{
No rasto das mulheres na ficção policial em Portugal: fórmulas e singularidades*
}

\author{
Maria de Lurdes Sampaio \\ Universidade do Porto - ILC
}

«Parece que no campo só há vacas, e afinal dorme uma perversidade enorme debaixo daqueles malmequeres».

Clara Pinto Correia, Adeus, Princesa (1985)

«Meu amigo, eu só sei, e isso lhe garanto aqui, que, quando a lei é obrigatória, o não cumprimento da lei é crime».

Abel Barros Baptista; Luísa Costa Gomes, O Defunto Elegante (1996)

«- Não Vasco, há sempre qualquer coisas que se pode fazer. Não ser cúmplice. Levantar a voz. Não se deixar hipnotizar ou adormecer. E passar por vários países para abrir os olhos e não os fechar nos horizontes envenenados de uma só nação. Ser de várias pátrias ajuda-nos a conservar a lucidez e a decência».

Gabriel Magalhães, Os Crimes Inocentes (2018)

É facto assente que até aos anos de 1980 a história da literatura policial em Portugal é uma parte da Literatura traduzida e da história portuguesa da recepção de obras estrangeiras. Devido a factores diversos e interseccionados, desde a Censura do regime salazarista a formas ínvias de «censura» no sistema literário

\footnotetext{
* Este artigo foi escrito no âmbito do Instituto de Literatura Comparada, Unidade I\&D financiada por Fundos Nacionais através da FCT - Fundação para a Ciência e para a Tecnologia (UIDP/00500/2020). Opto pelas designações «literatura policial»e «romance policial» (ou «policial») num sentido amplo, tendo em conta a longa tradição destas expressões em Portugal e a importância que atribuo à função de investigação (mesmo na ausência de detective). O presente estudo é o resultado de um levantamento empírico de obras associadas ao género policial (em paratextos, na diegese ou no discurso crítico) e de uma análise interpretativa dos mesmos, visando apontar pistas para futuras investigações.
} 
(o imperativo de literatura de empenhamento e a forte hierarquia entre alta e baixa literatura), não houve, durante o período do Estado Novo, produção nacional significativa de romances policiais. O fenómeno intensificado de importação e de tradução de ficção policial, desde a década de 50, a partir de horizontes anglo-americanos, a divulgação, em 1953, de fragmentos de novelas policiárias de Fernando Pessoa, a «legitimação» de hábitos de leitura do género policial, decorrente da produção de um discurso teórico-crítico por parte de figuras de autoridade como João Gaspar Simões, não conduziram à escrita de romances policiais portugueses. O género tinha o selo de «estrangeiro» e esse rótulo era uma garantia de qualidade. Não admira, pois, que quando, nos anos 1960, alguns autores portugueses decidiram escrever romance policiais, o fizessem de forma camuflada, ao abrigo de pseudónimos estrangeiros, introduzindo no mercado nacional as suas obras, implícita ou explicitamente, na qualidade de traduzidas, com personagens e cenários criminais fora de Portugal. De entre os inúmeros autores que nos 1960 escreveram romances policiais moldados no romance hardboiled, ou cruzando este modelo com o do romance de espionagem e de aventuras, sobressaem, por uma notória diferença qualitativa das suas obras, os nomes de Dick Haskins (Andrade de Albuquerque) e de Dennis McShade(Dinis Machado). A trilogia de Dinis Machado, Mão Direita do Diabo (1967), Requiem para D. Quixote (1967), Mulher e Arma com Guitarra Espanhola (1968), é particularmente rica, em virtude do imaginário cinematográfico que a povoa e das técnicas experimentadas no sentido da novelização do cinema. Nas narrativas destes e de outros autores portugueses de policiais, quer o modelo seja o dedutivo quer o norte-americano, as mulheres desempenham os papéis já fixados pelos grandes mestres do policial e, reforçados, pelo cinema: vítimas, criminosas, femmes fatales, femmes fatales/vítimas, mulher-anjo (enfermeira, secretária) e outras subvariantes. Neste quadro, o terceiro romance de Dennis McShade, Mulher e Arma com Guitarra Espanhola, é uma curiosa excepção, dada a criação de uma mulher revolucionária de origem latino-americana (Berenice), que critica, como inútil e alheio a questões sociais, o trabalho solitário do (anti)herói do autor, Peter Maynard. O terceiro romance de Dinis Machado, reflectindo já o espírito de uma década marcada por várias lutas (na Europa e na América Latina), e influências da literatura e culturas da América Latina, era uma antecipação de tempos revolucionários e do silêncio que se verificou ao longo da década de 70 no que ao policial diz respeito.

Nos anos de 1960, não encontramos nenhum romance policial de autoria feminina (com ou sem pseudónimos) e a única excepção à convenção dos pseu- 
dónimos e da «exportação» do crime para território estrangeiro é Jorge Reis, autor do romance Matai-vos uns aos Outros (1961), que levaria Óscar Lopes a considerar, em recensão à obra, o impulso renovador e revitalizador que esta obra trazia ao romance português em geral.

É preciso esperar até aos anos 1980 para que haja uma produção nacional continuada de romances policiais e é, nesse contexto, que vão surgir algumas obras de autoria feminina que jogam com as fórmulas do policial. A década de 70, com escassez de romances nacionais no mercado literário, é um período de silêncio dos detectives, mas marcado pela publicação de O que diz Molero (1977), romance transmodal de Dinis Machado, com uma estrutura policial, cuja influência na literatura contemporânea portuguesa está ainda por estudar.

Os anos 1980 são caracterizados por uma revitalização da actividade editorial na área do policial: há a reedição de clássicos do género (a obra completa de Raymond Chandler, por ex.), publicam-se novos autores estrangeiros e há a revelação de vários autores nacionais, incentivados a escrever com a instituição do Prémio Caminho de Literatura Policial em 1982 e por uma atenção crítica mais séria e aprofundada dedicada ao género. As modalidades e tendências desta ficção nacional, que, em finais do séc. XX, ambientam os crimes em Portugal, foram já mapeadas em 2001, num verbete publicado na Enciclopédia Biblos, do qual retenho um passo da síntese então feita e que servirá de mote ao estudo presente:

O romance policial apresenta-se a muitos escritores (anos 80 e 90) como uma forma que se presta à interrogação e indagação dos mistérios da sociedade portuguesa do ante e pós-25 de Abril (do tráfico de drogas a actos terroristas, dos segredos comunistas à guerra colonial). É essa tematização dos mistérios nacionais que encontramos na narrativa alegórica-fantástico-policial de José Gomes Ferreira, 0 Enigma da Árvore Enamorada. Divertimento em forma de novela quase policial (1980). Seguem-se Morte no Tejo (1982), de Artur Cortez (ou a «surpresa de um policial português», em «Posfácio» de Manuel Gusmão) e Adeus, Princesa (1985), de Clara Pinto Correia (...) considerado por Vasco Pulido Valente como «o melhor romance policial destes últimos anos». (Kayman/ Sampaio 2001, II: 318)

Muitos outros títulos figuravam no inventário então realizado, que não podia deixar de incluir dois romances com intriga policial publicados em 1982: Balada da Praia dos Cães. Dissertação sobre um Crime, de José Cardoso Pires, e O Rio Triste, de Fernando Namora. Estes romances condensam fórmulas e vectores temá- 
ticos que se encontram em grande parte dos romances policiais de finais do séc. $\mathrm{XX}$, de que destacaria: em $\mathrm{O}$ Rio Triste, a vertente metaficcional e o topos do desaparecimento, filão este riquíssimo de toda uma ficção de países com regimes ditatoriais); ii) a «Vocação» realista da investigação de Balada da Praia dos Cães e a criação, no inspector da Polícia Judiciária, Elias Santana, de um investigador verosímil. Partindo de um enigma policial, ambos os autores se concentram no passado histórico recente de Portugal e procedem a uma revisão e reinterpretação de factos do período da ditadura, estabelecendo uma «identidade» entre «a investigação policial e a procura da verdade histórica», como escreve Ana Isabel Briones, num ensaio dedicado ao estudo de Rio Triste, Square Tolstoi, Adeus, Princesa. ${ }^{1}$ Com pertinência, a autora acentua a importância que adquirem, nestas obras, o resgate do passado do esquecimento a que fora votado, o que contribui para a «catarse pessoal e colectiva» (Briones 1998: 275).

Os romances de intriga policial ou simplesmente policiais, publicados nos anos 1980 e 1990, estão em sintonia com muitas obras de ficção não policial desse período, participando no processo de «autognose nacional», que Eduardo Lourenço aponta como uma das «tendências predominantes» da ficção portuguesa de finais do século (Lourenço 1992). São disso exemplo as obras produzidas por Modesto Navarro (também Artur Cortez), criador do detective português Diplo/Artur, e de Henrique Nicolau, autor mais eclético, onde rastreamos influências quer do hardboiled americano quer de obras de Camilo Castelo Branco. Estes e outros autores situam a acção das suas obras no período do pós-revolução, predominantemente nos meios urbanos, e utilizam o policial como instrumento de reconstrução da história e de crítica e de denúncia social. Pierre-Michel Pranville, num bem fundamentado estudo dedicado a Modesto Navarro, refere-se aos romances do autor como «policiais históricos», para sublinhar o seu forte comprometimento com a História. ${ }^{2}$

A tentação do policial, de que Mafalda Ferin Cunha fala no ensaio «A tentação do policial no romance português contemporâneo» (2002) estende-se também às escritoras, levando-as a escrever, a partir dos anos 1980, alguns roman-

\footnotetext{
${ }^{1} \mathrm{Cf}$. Ana Isabel Briones, «Género e Contragénero. Tópicos do romance policial na narrativa portuguesa», Revista de Filologia Românica, 1998, n.ํㅜ 15, (pp. 267-280), p. 274.

${ }^{2}$ Cf. Pierre-Michel Pranville, Sept romans policiers portugais révélés au bain de l'Histoire, enquêtes policières et quête d'identité: La littérature policière de Modesto Navarro (1982-2002), Paris, Université Paris 3 - Sorbonne Nouvelle (Mémoire de Master 2. Littérature Portugaise), 2009. Sobre este período, veja-se também estudo de Paul Melo e Castro, «Five Cases From 130 Years of Portuguese Detective Fiction, 1870s-2000s», in Iberian Crime Fiction, Cardiff, Vosberg, N., University of Wales Press, 2011, pp. 116-144.
} 
ces policiais ou obras que, em virtude de traços temático-estruturais, activam relações genológicas com o policial. ${ }^{3}$ Por ordem cronológica, as obras e autoras recenseadas no estudo que se segue são, para os anos 1980, as seguintes: Crime no Museu de Philosophia Natural (1984), de Maria Estela Guedes, Adeus, Princesa (1985) e A Arma dos Juízes (2002), de Clara Pinto Correia, E se Tivesse a Bondade de Dizer Porquê (1986), de Clara Pinto Correia e Mário de Carvalho, Esta noite sonhei com Brueghel (1987), de Fernanda Botelho, O Pequeno Mundo (1988), de Luísa Costa Gomes, A Fenda Erótica (1988), de Hélia Correia, Matar a Imagem (1989), de Ana Teresa Pereira. Na sua globalidade, e como adiante se verá, estes romances não podem ser rotulados de policiais nem mesmo quando a etiqueta editorial cauciona esta taxinomia. É o caso dos primeiros romances de Ana Teresa Pereira, publicados na Colecção Policial Caminho, fundada em 1982, e determinante para impulsionar a escrita feminina (assim como o prémio da Revista Máxima). Já o grande romance dessa década, Adeus, Princesa, de Clara Pinto Correia, surgia na colecção «Crime Imperfeito», da Relógio d’Água, nome bem adequado à especificidade deste romance. Por outro lado, há que frisar que estamos perante experiências episódicas, sendo inexistentes as autoras de séries romanescas. Por outro lado, se há «a tentação do policial», há também fugas, dissidências e transgressões em graus variados, algumas delas já abordadas no ensaio de Ferin Cunha.

É na década de 90 que registamos uma actividade mais intensa na escrita de narrativas policiais de autoria feminina, com alguns romances a apresentarem um embrião de detective feminina. Algumas escritoras vão além de experimentações pontuais na literatura policial, mas nenhum fenómeno se pode igualar ao que se passa em Espanha. ${ }^{4}$ Nenhuma autora como Alicia Giménez Bartlett, nenhuma investigadora como Alicia Petra Delicado. Maria do Céu Carvalho, escritora acerca da qual existe pouca informação biográfica, escreve a tri-

\footnotetext{
${ }^{3}$ Antes dos anos 1980, apenas dois nomes se destacam neste historial: Maria O'Neill (1873-1938) e Maria Archer (1899-1982). Empenhada nos direitos das mulheres, Maria O’Neill é autora, entre 1909 e 1910, de Um Imitador de Sherlock Holmes (reed. 2003, Caminho), as primeiras paródias em Portugal das histórias de Conan Doyle. Vale a pena (re)ler a novela «O Botão de Ouro», onde se denuncia a frequente usurpação e apropriação da escrita feminina por parte de homens. Já Maria Archer publica, em 1946, A Morte veio de Madrugada (Coimbra Editora), um excelente romance policial e romance de costumes ambientado na Lisboa dos anos 1940.

${ }^{4}$ Cf. ensaio de Elena Losada neste volume, Elena Losada Soler y Katarzyna Paszkiewicz (eds.), Tras la pista. Narrativa criminal escrita por mujeres, Barcelona, Icaria, 2015, 245 págs., e o projecto (coord. por Elena Losada) Mujeres y novela criminal en Espana (1975-2010): autoras, figuras e poder, víctimas y criminales / MUNCE (2012-2014), exposto na plataforma https://www.ub.edu/adhuc/es/node/544 (Último acesso: 3 Jan. 2020).
} 
logia Intermediários, Lda. (1994) Feijões Contados (1995) e Macau... bye bye! (1998), em que a questão do império português é crucial. Margarida Utne publica três romances cosmopolitas e transnacionais, Morte por um Fio (1997), Comboio para Roma (1998), Terra Incógnita (2000). Para lá destes nomes, há um conjunto significativo de escritoras que escrevem romances que utilizam dispositivos do policial e que recorrem à estratégia epistemológica da detecção para abordarem temáticas muito diferenciadas. As obras e respectivas autoras são, por ordem cronológica: A Casa Eterna (1991), de Hélia Correia, Litoral: Ara Solis (1991), de Wanda Ramos, Aquário e Sagitário (1995), de Agustina Bessa-Luís, Juízo Perfeito (1995), de Julieta Monginho, Delito sem Corpo (1996), de Ana Gusmão, O Defunto Elegante (1996), de Abel Barros Baptista e Luísa Costa Gomes, e vários romances de Ana Teresa Pereira, com constantes remissões para o género policial, mas não catalogáveis como policiais.

No século XXI, a presença feminina no género é quase nula - a menos que a divulgação de obras de autoria feminina seja muito deficitária. O século abre com o romance Este é o Meu Corpo (2001), de Filipa Melo, um romance de estrutura policial que traz a medicina forense para o romanesco nacional e, em 2012 , Ana Saragoça publica Todos os Dias são Meus (red. 2018), que se estrutura a partir de uma investigação policial, recaindo o protagonismo nos depoimentos das pessoas interrogadas. ${ }^{5}$ Em 2011, surge 0 Caso do Cadáver Esquisito, que reúne homens e mulheres em torno de uma experimentação lúdica, que releva a importância dos diálogos entre os media e das obras colectivas.

É neste século que assistimos à emergência de investigadoras mulheres, mas todas elas produto de romances de autoria masculina. Assim, no mesmo ano de 2013, Pedro Garcia Rosado e Francisco José Viegas criam, respectivamente, no âmbito da Instituição policial, a inspectora-coordenadora Patrícia Ponte e a inspectora Olívia Xavier da Costa em O Colecionador de Erva e, no ano de 2018, Gabriel Magalhães, em Os Crimes Inocentes, inventa a «novel investigadora», Rosarinho do Amaral, a primeira detective amadora portuguesa, que a dado momento se refere a si própria como "private-eye». A hesitação da protagonista na selecção da designação a adoptar traduz a dificuldade de sempre na nomeação de uma profissão ou actividade inexistente em Portugal, mas projecta o problema mais premente da identidade (do indivíduo, de uma profissão) e das incertezas no mundo contemporâneo.

\footnotetext{
${ }^{5}$ Cf. entrevista à autora em https://www.delas.pt/ana-saragoca-a-autora-de-todos-os-dias-sao-meus-em-entrevista/conversa-delas/410294/(Último acesso: 14 Jan. 2020)
} 
caracterizam os inúmeros detectives do nosso imaginário: nem extraordinárias faculdades dedutivas ou abdutivas, nem emasculação, nem segurança e experiência, nem obsessão ou sequer interesse pelo crime e pela investigação. Como ele confessa ao fotógrafo que o acompanha: «- Sebastião, isto é a vida real. Não é um romance. E eu não sou um detective. Nem sequer gosto de histórias policiais» (p. 291). Estagiário num jornal sensacionalista da capital (Actualidades), cumpre uma obrigação que lhe é imposta - investigar o caso da jovem de 16 anos suspeita de matar o namorado, um mecânico alemão da Base Aérea de Beja - e, no final, depois ver a reportagem recusada, é despedido do jornalismo. Peixoto decide dedicar-se ao Direito e, à revelia de todos os finais detectivescos, o romance termina com um caso amoroso no horizonte.

Dir-se-ia que Adeus, Princesa ainda preserva um dos traços do private-eye e seus discípulos: a misoginia do investigador. A aversão pelas mulheres surge verbalizada em vários momentos do romance, culminando num passo: «Odiava-as a todas, pronto. Odeio as mulheres» (p. 145). Mas todos os actos de Peixoto denegam estas palavras e a primeira imagem que dele obtemos é a de um homem tímido, resignado, com uma paixão não correspondida por uma colega da redacção (Ana Mafalda Guerra), e que, com fidelidade canina, aceita a humilhação pública que esta lhe inflige. Esta inversão dos papéis de género, ainda que em modo humorístico, acentuará, por contraste, a situação de subalternidade das mulheres na província, e impedirá também uma polarização simplista entre homens e mulheres. Se Peixoto é o «eterno vencido» (e derrotado na vida pessoal e profissional), Ana Mafalda é, mesmo sem nada fazer, a eterna vencedora. Quase ausente, pois surge apenas no início e no epílogo da narrativa, esta é uma mulher determinada, assertiva e ambiciosa que parece não olhar aos meios para atingir os fins - pouco conforme às representações femininas da altura, na ficção e fora dela. Clara Pinto Correia poderia ter criado, com esta personagem, a primeira detective da ficção portuguesa, mas optou por não o fazer - muito provavelmente em nome do princípio da verosimilhança que rege a narrativa. Se a comunidade rural se fecha ao inquérito levado a cabo por uma dupla de homens, mais se fecharia a uma investigação conduzida por uma mulher. Por outro lado, a escolha de jornalistas-homens presta-se melhor à criação de cumplicidades no masculino e à representação de estereótipos de género e de discurso eivados de preconceitos e de violência, como na fala do chefe da polícia de Beja: «- Ó meu amigo, isso você vá por mim que eu já podia ser seu pai, elas depois dizem sempre que a gente estava tentando violá-las» (p. 51). 
No que diz respeito à estrutura narrativa, Pinto Correia preserva ainda a dualidade do policial convencional (segundo Todorov) entre história do crime (oculta ou in absentia) e a história da investigação jornalística (in praesentia), mas esta última, espécie de suplemento ou Apêndice, não nos conduz à história do crime nem à determinação do culpado. Na verdade, ela conduzir-nos-á a um «labirinto narrativo» ${ }^{6}$, enquanto desvela o fracasso ou a (quase) ausência de outras investigações possíveis: i) a investigação policial, dada rapidamente como concluída (já caso arquivado); ii) a história da investigação em falha (elipse narrativa e ideológica), aquela que poderia ter sido levada a cabo por parte de representantes da vítima (a entidade patronal, o consulado alemão, a família, etc.). O comandante da polícia dirá aos jornalistas lisboetas que o crime do alemão não pode ser imputado à jovem Maria Vitória (Mitó), mas a contrabandistas, espécie de deus ex-machina (a autoridade acata a tese do pai da jovem), que deixa intocável a comunidade. A confissão de assassinato de Mitó, bem como a quantidade de testemunhos que apontavam para uma relação passional violenta com o namorado, foram facilmente descartados, atitude esta motivada por uma espécie de instinto de sobrevivência comunitária e de ocultação do nepotismo e de tráfico de influências locais que a todos implicam. No final, todas as hipóteses de explicação do crime, longamente discutidas pelos dois jornalistas, se equivalem, ficando a história do crime em aberto; o leitor pode escolher uma das três versões expostas ou imaginar mais versões (nomeadamente a de uma morte encomendada, em nome de ancestrais códigos de honra). No final, tal como em 0 Delfim, de Cardoso Pires, não há apuramento da «verdade», mas há o desvendamento de inúmeros problemas da sociedade portuguesa de meados da década de 80: o desespero dos trabalhadores alentejanos perante o desmoronamento dos seus ideais, a falência das cooperativas, as assimetrias entre a capital e a província, o profundo desencontro geracional, conflitos entre formas tradicionais de vida e processos epidérmicos de modernização (as discotecas e as boîtes), o desalento e a falta de horizontes para os jovens do interior («Não estudam, não trabalham»; p. 45). As palavras de revolta do pai de Mitó chegam até nós:

\footnotetext{
${ }^{6}$ A expressão é de Paulo de Medeiros, no ensaio «Na entrada do labirinto: para uma abordagem teórica da narrativa de Clara Pinto Correia» (1996), pp. 59-67, que nos oferece uma leitura instigante dos romances Adeus, Princesa e de Ponto Pé de Flor a partir dos conceitos de «literatura menor» e de «desterritorialização», chamando a atenção para o que designa por «estratégias claramente anti-hegemónicas» (p. 67) da escritora.
} 
Um dia isto acaba tudo, amigo. Você há-de passar aqui e ver só terra queimada, rachadinha do sol, não hão-de ficar cá homens nem mulheres, hão-de debandar todos, um a um. Está tudo morrendo, tudo, quem quer saber agora da morte de um alemão? Ao governo que nos mata a nós não há vergonha que chegue... (p. 131; itálico meu)

Como defende Helena Kaufman (cf. 1993), em sintonia com a «nova criminologia» dos anos 1980/90, o crime individual é em Adeus, Princesa, uma manifestação do «crime social». De facto, os problemas não se situam no crime pontual e isolado, mas em «crimes» de ordem colectiva decorrentes quer de políticas centralizadas, que o pós-25 de Abril apenas mitigou, quer de ligações profundas com um passado de repressão, na origem de uma sociedade profundamente patriarcal de que as mulheres são as principais vítimas. A condição da mulher no contexto rural (um dos temas axiais do romance), o seu continuado confinamento ao espaço da casa, é denunciado por uma das vozes mais lúcidas de Adeus, Princesa:

Às vezes dá-me raiva, mas dá-me raiva por ter nascido rapariga. Eles entre homens ainda andam pelos cafés, primeiro num, depois noutro, passam-se assim tardes inteiras. Não é divertido, mas ao menos estão na rua. Nós estamos em casa. (...) Mas, se formos com eles para a cama, vão-se logo gabar para o pé dos amigos, e a fama já ninguém nos tira. Admiras-te que as moças só pensem em casar. Também não é divertido, mas sempre é uma segurança». (p. 91)

Bárbara Emília, a voz desta denúncia, Mitó, a sobrinha, a mãe desta, e todas as mulheres de Baleizão simbolizam a situação das mulheres reprimidas e submetidas a uma ordem patriarcal difícil de combater. Mitó, a suspeita do crime, é «ilibada» pelo pai e amigos, mas é condenada ao silêncio e à invisibilidade, tendo no horizonte um colégio interno de freiras - o lugar concentracionário do séc. XX homólogo do convento oitocentista. Já Bárbara Emília procura na capital a libertação de um casamento falhado e da opressão social, mas cedo a liberdade conquistada se revelará ser pura ilusão. Como se não houvesse qualquer fuga possível à fatalidade inscrita nos versos do cancioneiro alentejano, citado no romance: «Para a mulher ser infeliz / basta-lhe só ser mulher» (p. 239).

Por tudo isto, a narrativa inscreve no seu interior uma espécie de justificação do crime do homicídio do alemão, em que Mitó-agressora surge como uma espécie de heroína e justiceira, vingadora de todas as ofensas e abusos cometidas contra as mulheres (desde os castigos corporais do pai às provações de Mariana Alcoforado, com a qual pode comparar-se), mesmo que o crime não tenha pas- 
sado do pensamento à prática e tenha surgido em forma de desejo e de ameaça verbal, reportados pela voz da tia:

E mato-o. Mato-o. Eu agora mato-o e acabou-se. Não se ri mais de mim. Mato-o pela Mila que nunca será capaz de matar o Tomás, pela Bárbara que nunca matará o Augusto, pela Vi que atura o Fernando, pela minha mãe que atura o meu pai. Mato-o de uma vez por todas, mato tudo com ele. Pela Fátima e pela Adília, que ainda hoje não têm namorado porque, aqui há muitos anos, um dia fugiram de casa. (Pinto Correia 2002: 115)

Que o crime tivesse sido cometido pela jovem alentejana é um desejo que ultrapassa mesmo a questão de género, podendo equacionar-se em termos ecológicos e socio-económicos, em sintonia com uma ideologia popular do crime. É o que diz outra personagem (masculina) do romance, que lamenta a agonia da terra, destruída pela monocultura, e para quem o crime de Mitó seria sinónimo de rebelião e de reacção à letargia generalizada. A versão oficial do crime é, em certa medida, sinónimo de medo e de derrota.

Reencontramos as personagens de Joaquim Peixoto, Bárbara e Sebastião Curto no romance A Arma dos Juízes (2002), transpostos para os subúrbios da capital, a braços com problemas que parecem apontar para um corpo social decadente e doente. Peixoto tornou-se dependente de drogas, Bárbara Emília (mãe de Catarina Eufémia) consulta regularmente um psiquiatra, as relações humanas são frágeis e efémeras. O romance situa-se na mesma linha de denúncia e crítica social de Adeus, Princesa, mas deve já pouco ao modelo do policial: mais parece um diagnóstico clínico de uma sociedade enferma e de um país em estado de inércia e de indiferença. O tema de eleição é o homicídio da mulher e do filho levado a cabo por um todo-poderoso juiz. A morte fora anunciada, mas ignorada. Esboçaram-se tentativas jornalísticas de denúncia dos actos violentos do juiz, mas as reportagens são misteriosamente silenciadas, pois o agressor entrava a actuação da justiça. No final, há um quadro de grande actualidade: o juiz assassina toda a família e suicida-se de seguida.

Entre Adeus, Princesa (1985) e A Arma dos Juízes (1986), a par de outras obras, Clara Pinto Correia escreve, em parceria com Mário de Carvalho, o livro E se tivesse a Bondade de Dizer Porquê? (1986), publicado originariamente em folhetins, no Diário de Notícias, entre 13 de Outubro 1985 e 4 Maio de 1986. Trata-se de um encontro feliz e lúdico entre autores que procuram a renovação no campo romanesco (Mário de Carvalho desviava-se do cânone realista e explorava, desde 1981, 
com Contos da Sétima Esfera, a via do fantástico e a forma breve do conto) e o resultado é uma obra híbrida, um cruzamento de ficção científica com fantástico e ficção policial e algo de romance cor-de-rosa. O início da história situa-se algures na Rússia no séc. XXI (o nome de Gnoseogrado convoca todo um imaginário associado ao Estado soviético), e a acção recuará depois até aos anos 1980, numa chegada dos viajantes do tempo à arcaica cidade de Lisboa. O nonsense e o humor atravessam toda a narrativa, deixando espaço para a crítica social e para quadros de irónica profecia:

Em vinte anos, toda a Europa acertava o passo por esta capital, uma das primeiras a ascender ao estatuto de cidade-estado assim que a Nova Organização entrou em vigor. Olhem à vossa volta, e verão como tudo floresceu em Lisboa: a investigação, as letras, as artes, tudo aqui mexe e se pauta por uma exigência inconfundível de qualidade. Universidades dinâmicas, edições em catadupa, a música mais sofisticada, a política de espectáculos mais vigorosa ... é Lisboa, o paraíso da criatividade, da inteligência, da alegria. (pp. 128-129)

No Prefácio à obra, Ernesto Rodrigues refere-se-lhe como uma «nova Estrada de Sintra» e acentua um aspecto fulcral na obra: «o motivo da viagem (subsumida na fórmula da perseguição)» (p. 18). Um motivo transversal a vários romances aqui estudados, como em a Fenda Erótica, de Hélia Correia, que, aliás, mantém muitas analogias com o romance-folhetim de Clara Pinto Correia e de Mário de Carvalho.

A Fenda Erótica surgiu originalmente também em forma de folhetim, em 0 Jornal, entre 6 de Fevereiro e 18 de Setembro de 1987. A autora experimenta as fórmulas das narrativas de mistério e de aventuras, partindo do topos do desaparecimento de uma mulher, numa reescrita da fórmula mais habitual. Deste cruzamento resulta uma história rocambolesca, repleta de peripécias, que conduz o leitor, à imagem do marido-detective amador, na peugada da mulher em fuga, numa viagem vertiginosa por lugares exóticos do Norte de África e por lugares obscuros do mundo do crime. Indo ao encontro das expectativas do leitor de folhetins, não falta a clara explicação do mistério: estamos perante um caso de rejeição, por parte da mulher, do tédio, do seu modo de vida burguês e acomodado. As reflexões são esclarecedoras: «A vida chata da senhora casada com o seu par de filhos que um dia hão-de crescer e deixá-la sozinha, com o seu maridinho tão bom, tão regular, que não levanta a voz e já não tem mistério. Sente-se de algum modo emparedada viva» (p. 43). O envolvimento no crime (através do 
amante) surge como o corolário lógico de uma dupla e voluntária transgressão da «normalidade» por parte da mulher: dos valores da classe burguesa em que se integrava e das leis que regulam as acções dos indivíduos em sociedade.

No reverso de Fenda Erótica, mas convergindo na transgressão dos valores burgueses, e na existência de um casal em desencontro, está o romance de Fernanda Botelho (1926-2007), Esta Noite sonhei com Brueghel, também publicado em 1987. Trata-se de uma narrativa complexa, multiestratificada e dominada por vozes no feminino, em solilóquios e profusão de diálogos - que não mascaram o tema da incomunicabilidade - através dos quais o leitor vai inferindo a existência dos acontecimentos. A história conclui com o deslindar do mistério central e com uma espécie de retorno a um equilíbrio profunda e demoradamente perturbado. Nesta obra, a aproximação ao género policial (e poderia sê-lo também à psicanálise) é sugerida no âmbito diegético pela narradora-protagonista:

É como se tentasse resolver qualquer coisa, resolver-me a mim... eu, como nas histórias policiais, ou melhor: nas investigações das histórias policiais. Tudo tem importância, o mínimo pormenor: um gesto, um olhar, a cor de uns sapatos... Tudo pode concorrer para a solução do mistério. Cada um desses pormenores, por si só, não tem qualquer sentido transcendente, mas todos eles em bloco... E como poderei vê-los, apreciá-los em blocos se não os registar numa sequência, que, além de os conter também ao mesmo tempo os «causalize» (...) Para solucionar o mistério, o investigador pede às testemunhas que falem, falem, falem... Claro que as testemunhas escondem indícios, em ficção tem de ser assim, têm de ocultar, se não ocultarem, a história acaba logo, mal começou e já acabou. (...) estou a investigar. Exponho os factos, completo-os pela imaginação. Alguma coisa há-de sair... quero eu dizer: de concludente. Ordeno e examino os factos, na sua globalidade. (p. 163 e p. 164)

Este excerto traduz a familiaridade da autora com o género policial na clara percepção do paradigma indiciário e do princípio de causalidade que sempre nortearam o género. No papel de investigadora ocasional, a narradora entrega-se a um exercício edipiano de auto-conhecimento pela escrita de uma narrativa autobiográfica, e, através das palavras e de inferências, chegará à clarificação de mistérios privados e à determinação da «culpa» e das razões da "punição» do marido. Mulher de espírito independente, Luíza, qual moderna Penélope, não escapa à ordem falocêntrica. Reservado para a cena final, à imagem dos policiais da Golden Age, fica a reinterpretação das palavras e dos actos e o estabelecimento da verdade. Depois de especulações e incessantes interrogações, estabelece-se o 
princípio de causalidade procurado e algo de «concludente» emerge da ordenação de factos descontínuos. A indiferença e a marginalidade a que Luíza fora votada pelo marido durante doze anos (no silêncio, no desprezo, na ausência de relações sexuais) eram uma forma de punição pela sua infidelidade conjugal. A «culpa» conjuga-se aqui no feminino, não se circunscrevendo ao corpo e ao adultério; a gravidez ectópica, que denunciara o «crime» da mulher, é sentida por esta como uma falha - e nem a ironia que atravessa a sua narrativa dissipa esta culpabilização. Em aberto, para juízo dos leitores, ficará a questão da ocultação da esterilidade por parte do homem e o «julgamento» da esposa, sem que a voz desta seja ouvida.

Em 1961, Fernanda Botelho (a única mulher entrevistada) respondera a um Inquérito levado a cabo por Arnaldo Saraiva em que se questionava a legitimidade da distinção entre «Literatura Maior» e «Literatura Menor» e de outras dicotomias usuais - «romances policiais»vs. «romances-romances»; «romances policiais» e «romances cor-de-rosa», etc. - bem como a validade dos critérios utilizados nesta taxinomia. ${ }^{7}$ Na resposta a essas questões, a escritora parte de uma diferenciação dos leitores em função de factores etários e de «estádios de cultura» atingidos, e considera útil uma literatura menor «com desígnios puramente recreativos», deixando, porém, uma importante ressalva:

À literatura policial e de mistério não se aplicam, porém, tais considerações, sendo dado que, neste domínio, certas, e não raras, obras existem que, pelo seu rigor, estilo e técnica, se incluiriam de preferência numa escalão perfeitamente diferenciado da chamada «literatura menor» (...). Falando já em «rigor», «estilo»e «técnica», estabeleço já uma aproximação com a chamada Literatura, reputando inútil o acrescento «maior», sendo dado que o termo «Literatura» se basta a si mesmo. (Botelho 1973: 90)

O romance Esta Noite sonhei com Brueghel reforça a convicção expressa neste depoimento, ao incorporar uma dimensão autorreflexiva, em que a questão do policial (técnica, processo de descoberta, temática) é indissociável das questões do conhecimento (da autobiografia e da biografia), através das quais se materializa uma grande história que tem tanto de íntima (privada) quanto de política.

\footnotetext{
${ }^{7}$ Este inquérito, originariamente publicado na revista Rumo, n. .58 , Dezembro de 1961 , foi reeditado em 1973 no livro Encontros Des Encontros, Porto, Livraria Paisagem, pp. 83-91.
} 
O Pequeno Mundo (1988), de Luísa Costa Gomes, prefaciado por Abel Barros Baptista, é um romance bem conhecido, entre outros aspectos, pela sua advertência inicial e interpelação ao leitor de que a obra em causa não trata de questões sócio-políticas ou realidades nacionais, não obstante existir, em pano de fundo, um pequeno mundo provinciano. Estamos perante uma hábil narrativa pós-modernista, lúdica, que incorpora a hermenêutica da suspeita generalizada tão cara ao policial para sabotar a própria lógica narrativa do género. Através de narrativas epistolares, inscritas numa tradição literária nacional (de Camilo Castelo Branco a Eça de Queirós), os mistérios multiplicam-se, num processo de centrifugação que gera o caos e a incerteza acerca de tudo: da identidade das personagens e seus nomes, do sentido e racionalidade dos seus comportamentos, da factualidade dos actos referidos, da in/existência de crimes, em suma, da (in)verdade das histórias contadas. Nesse pequeno mundo, e reescrevendo um dito de um dos intervenientes do jogo epistolar, «as histórias (...) infinitamente se recomeçam» (p. 346), e com elas proliferam as teorias (clínicas e judiciais) e as especulações, sem que algum esclarecimento estanque a máquina narrativa e ensaística em acção. A obra não se esgota em exercícios formalistas de pastiche e de paródia, mas instiga o leitor a uma reflexão sobre a natureza da literatura, e, muito em particular, da leitura, dos modos de ler e da ética do ler.

Questões estas que serão retomadas em finais da década de 90 num outro romance epistolar, de Luísa Costa Gomes, agora em parceria com Abel Barros Baptista, e que incluímos na categoria de anti-detective novel. Trata-se de O Defunto Elegante, obra escrita a várias mãos: de Luísa Costa Gomes e de Abel Barros Baptista, mas que conta ainda com a colaboração pontual de Clara Pinto Correia e de Mário de Carvalho. A forma epistolar e a índole parodística da narrativa prestam-se, como em 0 Pequeno Mundo, a um processo narrativo diastólico exacerbado, que redunda no enfraquecimento da intriga. As derivações, ramificações, diferimento, interrupções e desconversas (termos-chave retirados do próprio texto) são constantemente sinalizados perante o leitor mais desatento, evidenciando a acentuada vertente autorreflexiva e metaficcional de O Defunto Elegante, bem como uma relação intertextual com grandes textos da literatura ocidental. Confluem nas páginas iniciais o romanesco e o ensaístico: discute-se a natureza do romance, o vedetismo dos escritores, a ânsia de visibilidade, o campo literário, o «superavit de ficção» (p. 15). X, autora de muitas epístolas, apresenta uma teoria do romance, que surge como negação do policial, pois se afirma que se pode fazer um romance sem os expedientes fáceis da «ilegalidade» ou «crime» 
e sem «histórias». «Quando muito, pode haver 'mente incriminativa', argumenta» (p. 16). Já Y, principal destinatário de X, e aspirante a romancista, elabora uma teoria do romance que parece contemplar a espécie policial tal como J. L. Borges e Umberto Eco a perspectivaram:

É o crime como metáfora da desordem introduzida na ordem, o crime como princípio da descoberta, o crime como dispositivo de organização e principalmente o crime como instrumento de delimitação da narrativa: princípio, meio e fim, entendes?, se te lembras um pouco do Aristóteles que terás lido na faculdade. (p. 21)

Num outro passo, Z escreverá: «Também li que o romance policial é genuinamente aristotélico, por ser o paradigma de uma ficção que segue as prescrições do Aristóteles sobre organização da história ou intriga, conforme se traduza a palavra grega que julgo ser mythos» (p. 24). À luz da teoria aristotélica do mythos, O Defunto Elegante não é um romance policial, mas não deixa de oferecer ao leitor muitos dos ingredientes do romance policial de enigma, que tematiza obscuros negócios imobiliários, e cuja verve cómica e satírica se apreende em sentenças do género: «Meu amigo, eu só sei, e isso lhe garanto aqui, que quando a lei é obrigatória, o não cumprimento da lei é crime» (p. 25). Tanto as personagens X como Y encarnam (voluntariamente ou não) o papel de detectives, para investigar acontecimentos «estranhos», não faltando um cadáver (o defunto elegante), cuja identidade se averigua. Instalada a suspeita generalizada e a desconfiança, tudo passa a ser «significativo» e indício de crime. Mas nem o «encadeamento de factos estranhos» consegue travar os subenredos e a proliferação de hipóteses explicativas, de sobreinterpretação, ou mesmo de interpretação paranóide. $O$ facto de os narradores serem professores universitários, treinados na análise literária (i.e., na leitura) e na reflexão teórica sobre a literatura e sobre a linguagem não é pura coincidência. Há em 0 Defunto Elegante uma clara homologia entre o papel do detective e do crítico literário, e a reiteração no texto de verbos comuns às duas actividades, como pesquisar, investigar, indagar, averiguar.

As obras de Luísa Costa Gomes ajudam-nos a perceber por que é que o policial é, por excelência, o género que mais convoca o leitor, como sustenta Marion François, no ensaio «Le lecteur, 'Pièce Maitresse de l'Appareil' Policier» (2006): «Le roman policier a été immédiatement perçu comme le livre du lecteur, e il a probablement été le premier domaine de la littérature écrite où l'on ait étudié le fonctionnement du récepteur. (...) La lecture est elle-même une démarche herméneutique» (François 2006). 
No final da década de 80, há a assinalar o aparecimento da escritora mais singular da ficção portuguesa contemporânea, referida inúmeras vezes como autora de romances policiais: Ana Teresa Pereira. Em 1989 publicou o seu primeiro romance, Matar a Imagem, imediatamente distinguido com o Prémio Caminho de Literatura Policial. Em 1990, vem a lume, na colecção Policial Caminho, Personagens, e, em 1991, na mesma colecção, A Última História (1991). De aí em diante seguem-se dezenas de títulos (cerca de 50), como se estivéssemos perante uma espécie de romance contínuo, ancorado na circularidade e na repetição, traços obsessivos da escrita da autora que Rui Magalhães já assinalava em 1999, no seu livro, O Labirinto do Medo: Ana Teresa Pereira. Nesse estudo obrigatório para qualquer investigador desta escritora, o ensaísta e filósofo dava conta das dificuldades em classificar a obra da autora, e através da exploração de dois modelos interpretativos (psicológico e simbólico), equacionava as relações dessa obra com o policial e com o fantástico (não entendido o «fantástico» apenas como «género literário») para evidenciar uma proximidade com este último e uma ligação mais frágil ao policial. Rui Magalhães argumentava que, se quase todas as histórias de Ana Teresa Pereira tinham histórias de crime («reais ou imaginários»), elas não seguiam um princípio básico do género: o da clarificação final das ambiguidades e obscuridades da história contada: «O que de policial existe aqui (...) não é pois o crime, mas o espaço mental de preparação do crime: a imaginação, a concepção do crime ou, mais simplesmente, a ideia de anulação como única saída para um conflito» (Magalhães 1999: 55; itálico meu). O ensaísta apresentava ainda uma instigante teoria que urge revisitar e desenvolver a partir de noções fecundas como, por exemplo, a de «desterritorialização»:

O policial, o caso mais evidente de negação do literário, de abandono da preocupação estilística [da dicção, diríamos]. 0 policial ou o fantástico são, sobretudo, formas de um outro poético. Também o poético é, paradoxalmente, o abandono da literatura. § A literatura imita o real. Através de efeitos retóricos específicos, é certo, mas é sempre imitação. O poético e o fantástico, pelo contrário afastam do seu lugar o objecto da representação, instituem percursos que viabilizam a suspensão dos seus efeitos ontológicos e poder. Procuram não instituir novos lugares, mas espaços de fuga. (Magalhães 1999: 35; itálico meu)

Entre 1999 e o presente, a obra de Ana Teresa Pereira suscitaria muitos e importantes estudos académicos, e todos eles apontam a idiossincrasia de uma autora, cujas relações com a tradição literária portuguesa são quase nulas - o 
que explica a surpresa do público brasileiro perante a obra Karen, (2016) vencedora do Prémio Oceanos, 2017. ${ }^{8}$ De facto, estamos perante uma obra original que poderemos incluir na categoria de transnacional ou de «world literature», não só porque o mundo de referências das histórias da autora é anglo-americano, mas também por causa dos cenários, da onomástica, da toponímia, e do uso abundante de expressões inglesas (nos paratextos, mas também no texto romanesco). Born transmedial poderia ser também o mote para a abordagem das obras de Ana Teresa Pereita, cuja materialidade (as capas, por ex.) aponta de imediato para as várias relações - de porosidade, de intersecção, de cruzamentos - que as suas narrativas entretecem com outras artes e com outros artistas. Depois do estudo de Duarte Pinheiro sobre a relação com o cinema, a investigadora italiana Gaia Bertoneri tem vindo a explorar as obras pereirianas em função do conceito de «fractal» e do paradigma do «pictorial turn».

O estudo dessa obra à luz do género policial é, sem dúvida, incontornável, ${ }^{9}$ não para a categorizar como policial, mas para evidenciar a importância deste modelo narrativo na sua produção literária e no seu imaginário. Primeiro, porque não há nenhuma escritora em Portugal que de forma tão sistemática tenha reflectido sobre o género - em entrevistas, paratextos e, de forma regular, no âmbito das próprias obras de ficção (há micro-análises de livros, comentários diversos, etc.). Das várias obras passíveis de citação, destaca-se a colectânea Histórias Policiais (2006), onde a autora oferece uma leitura revisionista e inovadora do género e das narrativas classificadas como «policiais». Histórias Policiais é, em função do primeiro texto «Os Insuspeitos», uma espécie de catálogo ou roteiro de narrativas alternativas a qualquer Western Canon, enraizadas no imaginário ocidental, mas também um guia de leitura das próprias obras de Ana Teresa Pereira. ${ }^{10}$

\footnotetext{
${ }^{8}$ A propósito deste prémio e da singularidade de Ana Teresa Pereira, cf. António Guerreiro, «A escritora que na semana passada viu o seu último livro premiado pela APE não é facilmente classificável», Expresso. Atual, n.․ 2088, 2012, 3 de Novembro. Para um melhor conhecimento das obras da autora, são indispensáveis as teses de doutoramento: de Duarte Pinheiro, apresentada em 2010, e em livro, Além Sombras: Ana Teresa Pereira, Porto, Fonte da Palavra, 2011 e de Anabela Sardo, A Audácia de ser Diferente: a Escrita Obsessiva de Ana Teresa Pereira. Tese de Doutoramento, Aveiro, Universidade de Aveiro, 2013. ${ }^{9}$ Sobre este assunto, cf. dissertação de Mestrado de Patrícia Mota Freitas, Do Escritor como Predador: Mistério e (Re)Visões na obra de Ana Teresa Pereira, Porto, Univ. do Porto, 2011.

${ }^{10}$ Sobre este livro, cf. Anabela Sardo «A Propósito do texto 'Os Insuspeitos', As paixões de Ana Teresa Pereira», in Atas/anais do XXI COLÓQUIO DA LUSOFONIA, S. Miguel-Açores, 2014, pp. 75-86, in http://bdigital.ipg.pt/dspace/bitstream/10314/2399/1/Ata\%20Cientifica_anabelasardo.pdf) e Gaia Bertoneri, «Histórias Policiais di Ana Teresa Pereira: proiezioni per uno spettatore attento», in Hora fecunda. Scritti in onore di Giancarlo Depretis, a cura di Paola Calef, Francisco Estévez, António Fournier, Torino, Nuova Trauben, 2015, pp. 573-583.( Disponível em academia.edu).
} 
Segundo, porque num plano intratextual, são constantes as referências e remissões a personagens que ou são escritores de policiais ou são leitores e espectadores de ficção policial (em diversos suportes) - mesmo nas obras de literatura infantil como em A Casa dos Penhascos (1991). E há frases-refrão repetidas e omnipresentes na totalidade da obra, como, por exemplo: «Parecia um detective» ou «Como nos romances policiais» (cf. Num Lugar Solitário). Terceiro, e acima de tudo, porque desde cedo, há na obra pereiriana a percepção de que o que se considera um género formulaico é, no fundo, uma máquina autopoiética de produzir narrativas e de contínua reinvenção de variáveis: o possível a cada instante, a permutabilidade de papéis inscrita desde o início, as versões e hipóteses explicativas como células narrativas prontas a expandirem-se e a materializarem-se em novas histórias e em media diferentes.

Nos seus diferentes suportes físicos, o policial oferece à autora um vastíssimo repertório de temas, motivos e procedimentos prontos a usar e a serem reconhecidos pelo leitor possuidor de uma cultura média. No romance Karen (2016) são referidas séries televisivas coetâneas como Lewis, Inspector Morse, Inspector George Gently, e uma personagem fala do seu fascínio por Martin Shaw, Inspector em Northumberland. Cria-se, desta forma, um efeito de quase sincronia entre o tempo da escrita e o tempo de leitura e uma proximidade extrema entre o leitor e a obra, numa réplica da proximidade e familiaridade da própria Ana Teresa Pereira com as suas obras e figuras de eleição (Henry James, Daphne du Maurier, Hitchcock). A cada momento, pede-se a cumplicidade do leitor e estimula-se a sua memória e imaginação, com links que terá de activar («como numa história de Henry James»). A distinção entre leitor e autor esbate-se, inscrevendo-se a possibilidade da reversibilidade de papéis, que os meios tecnológicos do séc. XXI asseguram aos seus utilizadores. Ou de como a leitura é, em si, um acto que convoca uma actividade intensa do leitor, entendido não como simples receptor, mas como co-autor, ainda convocando as teorias da recepção e da leitura de um H. R. Jauss ou de Wolfgang Iser, mas indo muito além delas: «Today, texts are largely imagined as scenes of reading rather than of scenes of writing; this 'readerly' view of text has been most completely elaborated through the modern hermeneutical tradition in which text is not something we make but something we interpret» (McGann 1991: 4).

No entanto, há que sublinhar que as questões epistemológicas que dominam o policial desde os seus primórdios (a justificar a importância de reflexões sobre métodos de investigação), subordinam-se, nesta escritora, a questões de 
ordem ontológica; as convenções realistas diluem-se num universo diegético volátil e de vacilação, em sintonia com muitas das produções e criaturas emergentes no âmbito das humanidades digitais do séc. XXI. Tudo em Ana Teresa Pereira é um lugar estranho e a própria noção de «crime» se dilui numa atmosfera de mistério e fantasmática, mesmo quando nos remete para lugares empíricos que facilmente reconhecemos (certas ruas de Londres, por ex.). Ou com mais rigor: tudo é simultaneamente "familiar» e "estranho», tudo é instável (a começar pelo trânsito de personagens e de textos e fragmentos de livro para livro) - e bastaria ler O Verão Selvagem dos teus Olhos e Karen, para compreender isso. Muitas das personagens desta escritora assemelham-se mais a fantasmas, sombras ou seres incorpóreos do nosso imaginário pessoal e colectivo do que a seres humanos comuns, análogos aos que povoam o universo do policial. Embora haja uma predominância de protagonistas-mulheres, que não representam os papéis de género, os jogos de espelhos criados pela autora (com duplos, desdobramentos, réplicas), esbatem as fronteiras existentes entre géneros e sexos. A apropriação do lugar, do corpo e da mente do Outro é recorrente nas suas narrativas. A obra Karen, por exemplo, (onde o despojamento coexiste com a saturação de imagens) encena, uma vez mais, o tema da usurpação de identidade, mas a questão nodal reside no polo imaginação/memória ( $I m$ Imagining... no, remembering»; p. 80), que tanto pode reenviar-nos para discussões filosóficas sobre o papel da memória na construção da identidade individual como pode reenviar-nos para um debate bioético que só não é da ordem da ficção científica, porque de grande actualidade: as memórias que podem ser implantadas nos seres humanos ou em robots, a questão da definição do humano, em suma. Olhando para a totalidade da obra da autora, o que se destaca é muito mais do que um hibridismo de géneros ou de relações intermediais e transmodais. Há na escrita de Ana Teresa Pereira como que uma pulsão para romper e anular todas as fronteiras (e não apenas genológicas), levando-nos aos debates da nossa contemporaneidade sobre a multiplicação de identidades, sobre a desrealização do real ou sobre a realidade do virtual.

Enquanto muitos autores, na década de 80, recorriam ao modelo do policial para a revitalização de uma escrita realista de crítica social, o trabalho de Ana Teresa Pereira iniciava na década de 90 um gesto radical de ruptura com uma visão essencialista de literatura e com uma concepção de literatura nacional, recorrendo, com desenvoltura e paixão, a géneros como as fairy tales, o western, o gótico, os romances de aventuras, o fantástico e o policial (toda uma tex- 
tualidade marcada por imagens culturais de rápida difusão). Há um desterramento e exílio voluntário do cânone e da grande Literatura (a que é ensinada nas instituições). Em A Casa dos Penhascos, a mãe de uma personagem afirma (e poderia ser a escritora a proferir estas irónicas palavras): «Mas o David não vai escrever policiais. Ele quer escrever livros ‘sérios', quer ganhar o Prémio Nobel» (p. 44). As consequências imediatas deste afastamento do «sistema» são paradoxais: a autora é objecto de vários ensaios de grandes críticos e de estudos académicos, tem o seu clube de fiéis leitores, e, no entanto, é ainda, para muitos leitores portugueses uma autora completamente desconhecida.

\section{Anos 1990}

A década de 90 inicia-se com a publicação de dois romances em que a demanda da identidade se reveste de contornos filosóficos e míticos: Litoral, Ara Solis, de Wanda Ramos, Prémio Literário Cidade de Almada em 1991, e A Casa Eterna, de Hélia Correia. Há entre A Casa Eterna e Litoral: Ara Solis (ambos de 1991) notórias afinidades: a demanda de raízes, o retorno de uma personagem a uma terra de «origem» (biológica, mítica e/ou cultural), a deslocação de uma geografia urbana central para zonas periféricas - uma vila na província, algures no Norte de Portugal, no primeiro caso; o Cabo Finisterra, na Galiza, no segundo. Prossegue assim um descentramento geográfico operado por Clara Pinto Correia, em Adeus, Princesa, acompanhado por um processo de introspecção e de mergulho no âmbito do privado. Outro denominador comum reside na escolha de uma mulher como protagonista na indagação de um possível crime a envolver dois homens, cuja vida e morte são, em si mesmas, fonte de mistério. Inverte-se aqui um padrão recorrente na literatura policial em geral, em que a mulher é objecto do olhar do sujeito masculino - embora as detectives-amadoras ostentem os traços obsessivos de qualquer investigador masculino. Peter Messent explica-nos esse padrão:

Feminist epistemologists have pointed to the gender polarities that deepley mark a phallocentric Western culture, which has tended to associate masculinity with the search for knowledge, and feminity with the object of this search (...). In feminist this gender binarity is undone, for it is the woman detective who assumes the role of reading signs and chasing knowledge. The ultimate authoritative Reading is now a feminist tone, privileging women's voices, offering a woman-centred 
interpretation rather than masculine readings. Knowledge is power, and the enactement of this epistemological power is at the heart of the feminist crime novel. However, the ideal of powerful knowledge is qualified in feminist detective novels which (...) posit a subjective, involved, empathetic type of knowing (diferent from the objective, distanced knowledge which is the masculine epistemological ideal). (Messent 1997: 79)

Em A Casa Eterna, a mulher-narradora procura respostas para questões que extravasam as questões criminais: o que terá levado o seu ex-amante e escritor Álvaro Roiz a regressar, velho e doente, à terra onde nascera? Como vivera os seus últimos dias? Terá tido a sua morte causas naturais ou trata-se de um homicídio? Na ausência de um inquérito policial e perante a indiferença dos seus familiares, a narradora interroga e escuta. O pretexto para o interrogatório: a escrita da biografia do escritor. Tal como em 0 Delfim, os testemunhos e as versões dos conterrâneos de Roiz multiplicam-se em narrativas que revolvem o passado e entreabrem janelas para conflitos e segredos familiares que ninguém ousa desvendar. Como nota Mafalda Ferin Cunha «todos os que falam do poeta destilam fel mas pouco contribuem para desvendar com nitidez o enigma da sua personalidade» (Cunha 2005: 283). Sobressaem, nessa paisagem de província, «o orgulho de casta, o rancor, a inveja, o desprezo, o ódio, a vingança, aqui e além o amor» (ibidem).

A Casa Eterna é um romance que procede à desmistificação do retrato idílico do mundo rural, pondo em evidência um mundo arcaico - de que é indício a onomástica e as árvores genealógicas (os Amorins, os Baiões, os Roízes) -, como que parado no tempo, e averso a condutas desviantes (o anarquismo de Roiz) ou a forasteiros como a narradora. Um mundo paralisado por medos, que tanto dizem dos efeitos duradouros da ditadura como da tradicional desconfiança das classes populares em relação às forças policiais. Como na fala de uma caseira: «Bom. Se dá garantias que isto não vai mexer com a autoridade. Acho que eu não fiz nada contra as leis, mas é que um pobre nunca sabe o que vem escrito. Já se viu multas e prisões por um aí. E se a senhora jura que os patrões não se importam (...). Pois conto. Já agora, conto tudo» (p. 29). E a reiteração: «Mas oiça, ponha aí que eu não sabia e que não tive culpa. Ponha. Ponha outra vez. Dizer a mesma coisa por repetidas vezes, ele não há outro modo para as palavras de um pobre valerem qualquer coisa» (p. 33).

Confrontada com os muitos enigmas que as perguntas da narradora levantaram, e com a desconfiança com que é recebida pela população, os mistérios 
tugal pós-25 de Abril. Na contracção territorial após a perda do Império, e cinco anos após o ingresso de Portugal na CEE, em Litoral: Ara Solis volta-se costas à Europa, numa fuga em direcção a um «Paraíso perdido», lugar mítico e matricial das terras irmanadas de Portugal e Galiza. Propõe-se uma genealogia da anamnese colectiva portuguesa que recua até aos celtas e a esse lugar de memória que é o cabo Finisterra. Mas, ironia ou sinal da utopia contida em Litoral, o Cabo Finisterra foi escolhido pela União Europeia, em 2007, como um dos elementos com um «papel essencial na história e na identidade da Europa».

A questão da identidade colectiva e as relações de Portugal com as ex-colónias (sobretudo com Angola) e com o seu passado colonial marcarão a já referida trilogia de Maria do Céu Carvalho:Intermediários, Lda. (1994), Feijões Contados (1995) e Macau...bye-bye! (1998). Os três romances situam-se na linha de continuidade dos romances policiais como romances políticos dos anos 1980, de autores como Modesto Navarro e Henrique Nicolau, revelando fortes intuitos de crítica social, mas distinguindo-se da ficção desses autores por uma ostensiva vertente didáctico-pedagógica e por uma pulsão etnográfica e antropológica, na base de uma descrição pormenorizada de tradições e costumes africanos. Nos dois primeiros romances, abundam referências à gastronomia (angolana e cabo-verdiana) e longas descrições de paisagens do sul de Angola, com nomeação de lugares e elementos icónicos. Acresce a tudo isto, longos trechos de dissertação sobre a história e geografia de Portugal, sobre a história de Angola e sobre as relações históricas entre estes dois territórios.

A demanda de identidade é, como noutros romances policiais, a força propulsora da escrita, e estas narrativas integram-se também no corpus ficcional da geração literária da guerra colonial, da descolonização e dos «retornados» (portugueses e africanos), cujo marco foi a publicação de Os Anos de Guerra (1988), de João de Melo. No primeiro romance, Intermediários, Lda. (1994), há uma cartografia exaustiva de uma nova Lisboa no rescaldo do pós-revolução. A capital portuguesa surge como um espaço de profundos contrastes, marcado por personagens inadaptadas e deslocadas (dos retornados aos ex-militares), mas também como um lugar de zonas de contacto e de partilha de experiências e de memórias e, ainda, de miscigenação e de incorporação de hábitos e costumes africanos (da gastronomia à música). Maria do Céu Carvalho é, talvez, a primeira escritora a fazer um retrato de Lisboa como cidade mestiça, multicultural, poliglota, profundamente marcada pelo encontro com África nos mais diversos planos, e como cidade formada por comunidades africanas (visíveis e invisíveis) que em Lisboa 
continuam fiéis a hábitos culinários e religiosos dos lugares de origem e que põem em circulação um léxico e sonoridades de terras africanas.

Perpassa por toda a narrativa o tema da diáspora e a ideia de que a independência política das ex-colónias não destrói as ligações históricas, comerciais e afectivas entre Portugal e África e que elas se mantêm através de vias diversificadas (por ex., na cooperação luso-africana pós-independência) e actividades ilícitas como o tráfico de diamantes e de drogas. Ao leitor caberá decidir se as memórias e a profunda nota de nostalgia de África que atravessa este romance (e o segundo) traduz ou não um tardio luso-tropicalismo.

No segundo romance, Feijões Contados (1995), a autora aprofunda o retrato de Lisboa como cidade multicultural e cosmopolita, mas desloca parte da acção para África, procedendo a um desmascaramento de formas europeias de neo-colonialismo africano e da perpetuação de crimes diversos em África. O tráfico de diamantes desencadeia todo o tipo de violência e a loucura. A África exótica da literatura colonial ressurge nesta narrativa como espaço propício à concretização de todos os sonhos e à destruição de todos os interditos. Como num romance de aventuras, há a narração de um safari na Namíbia e a descrição pormenorizada de uma orgia nocturna em plena selva africana. Feijões Contados impõe-se como uma narrativa cinematográfica, profundamente sensorial, que combina fórmulas ficcionais diversas, e que traz à memória um filme como Apocalipse Now (1979). A perversão e o horror, esses são filiados no passado nazi de um milionário alemão (Beck) a residir em Portugal.

No terceiro romance Macau...bye-bye! (1998), com ingredientes dos romances de aventuras e da literatura de viagens, a autora explora a presença portuguesa em Macau, mas traz para primeiro plano as seitas e as máfias chinesas, apresentando Macau como um lugar de criminalidade generalizada. Subjacente à multiplicação frenética de peripécias está uma mal dissimulada crítica à transferência, então em curso, da região de Macau para a China, o que aconteceria em 1999.

O fio condutor de todas as narrativas é Júlio Mendonça, ex-combatente da guerra colonial, personagem que sofre de trauma de guerra, cujo passado é evocado ao longo das histórias através de flashes alucinatórios, da memória e de monólogos e diálogos com outras personagens, o que é corroborado pela indexação, em final de narrativa, de textos pretensamente documentais: no primeiro romance, uma ficha relativa a um processo militar ocorrido em Angola, e, no segundo, fichas relativas ao seu internamento no hospital psiquiátrico Júlio de 
Matos, com diagnóstico de «alteração pós-traumática do stress de guerra». O terceiro romance não inclui qualquer ficha, pois o final da história remete para um círculo vicioso e para uma situação fora de controle: Mendonça (já com 50 anos) continua a ter surtos alucinatórios e continua a matar, sem que alguém o impeça. A vertente realista do romance é, assim, reforçada por informações pseudo-factuais e que relevam o protagonismo de Júlio Mendonça e a questão dos traumas de guerra, um dos grandes tabus da sociedade portuguesa do pós-25 de Abril. Antes de Maria do Céu Carvalho, o tema da guerra colonial e da descolonização fora aflorado ou tratado em vários romances, mas com excepção dos romances de António Lobo Antunes, nunca o tema do trauma fora explorado tão exaustivamente ou de um ângulo que evidencia a dimensão colectiva do trauma. Dir-se-ia mesmo que o romance inicial da trilogia era motivado pelo imperativo de trazer à praça pública esse assunto tabu, cinco anos antes da Lei que contemplaria uma rede de apoio aos traumatizados de guerra. ${ }^{11} \mathrm{Na}$ contracapa constava um excerto esclarecedor e que justificava também a inserção do romance numa colecção policial:

A guerra colonial, como qualquer guerra, deixou marcas indeléveis e intransponíveis. Exigir que os "guerreiros» reassumissem o seu lugar na sociedade como se nada tivesse passado é o mesmo que fingir que as pessoas ou as sociedades são imutáveis. (...) A ligação das sequelas desta guerra com o estilo «negro» policial, de uma maneira eficaz e original, é uma das razões por que a Caminho se felicita por revelar, assim, um novo autor português: Maria do Céu Carvalho.

No segundo romance, Feijões Contados (1995), a nota publicitária destacava ainda o tema do trauma dos militares («as marcas profundas não resolvidas»), a não integração na sociedade, o esquecimento a que foram votados, em detrimento de qualquer passo da intriga desse romance de aventuras, com caçadas e orgias em África, passível de aliciar um maior número de leitores. Apenas a contracapa do terceiro romance Macau...bye-bye! (1998) é omissa em relação ao trauma, antes aliciando o leitor para uma deambulação pelo espaço de Macau e para a continuidade das actividades de um herói, aí designado também como «vilão».

\footnotetext{
${ }^{11}$ É só em 2000 que se cria a «rede nacional de apoio aos militares e ex-militares portugueses portadores de perturbação psicológica crónica resultante da exposição a factores traumáticos de stress durante a vida militar», instituída pela Lei n.ำ 46/99, de 16 de Junho (pub. Diário da República n.ำ 83/2000, Série I-A de 2000-04-07).
} 
A questão do trauma é tratado de forma exaustiva por Branka Hanisch na sua dissertação de mestrado, Aspekte des portuguiesischprachigen Kriminalromans in Werk von Maria do Céu Carvalho, e apresentada à Freie Universität Berlin, no ano de 2008. Em «Considerações Finais», escreve esta investigadora:

Com os seus romances, Carvalho mexe num dos maiores temas tabu da sociedade portuguesa no que diz respeito ao trabalho sobre o passado colonial: os efeitos psíquicos a longo prazo causados aos soldados pelo stress da guerra, como se manifesta na síndrome do stress pós-traumático. (p. 95; minha tradução)

Alicerçando teoricamente o seu estudo em teorias do trauma (estudos de psiquiatras e de antropólogos), a autora detém-se na figura do ex-combatente Júlio Mendonça, procedendo a uma análise pormenorizada das diversas facetas desta personagem masculina criada por uma mulher e que fazem dele um misto de anti-herói, de vilão e de «criminoso» inimputável.

De facto, Maria do Céu Carvalho cria em Júlio Mendonça uma personagem ficcional de excepção no panorama das letras portuguesas - não apenas na «literatura policial».É uma personagem complexa, de físico atraente e com alguma erudição, que incorpora na sua composição traços do herói hardboiled norte-americano (de Marlowe a Mike Hammer) e de outros anti-heróis do imaginário cinematográfico de Hollywood (sobretudo de Travis, de Taxi Driver). Mendonça tem muito pouco de investigador, mas a sua intervenção é catalisadora de acontecimentos que levam à revelação de crimes e dos criminosos. Traumatizado, inadaptado à vida «normal», dependente da mãe e de trabalhos precários e esporádicos (acompanhamo-lo entre os 30 e os 50 anos), Mendonça sofre de crises de pânico e de amnésia, com episódios de agressividade e de violência que redundam em homicídios, que nunca lhe são atribuídos. No passado, comandante, chefe do exército, detentor de poder, movendo-se num universo masculino; no presente, desempregado, humilhado, acompanhante de mulheres ricas e poderosas, no seu trabalho temporário de «chauffeur»e «intermediário para todo o serviço», para recorrermos às suas palavras auto-depreciativas. Em suma, Mendonça é um dos grandes derrotados da ficção portuguesa contemporânea.

Inovador no romance de Maria do Céu Carvalho, Intermediários, Lda., é a abordagem do trauma a partir da voz e da perspectiva de uma mulher (a mãe de Mendonça) e do profundo impacto psicológico na sua vida quotidiana. A obra 
abre com Luísa a desabafar com uma amiga os problemas causados pela situação do filho: a cedência do seu próprio quarto, as dificuldades financeiras, o seu papel de mãe cuidadora de um filho adulto (30 anos) que a confronta, e as constantes preocupações com uma situação que a ultrapassa. Viúva, velha, cansada, a arrastar compras diariamente, vive do aluguer de quartos a estudantes, e não se conforma com uma realidade que não compreende. Em Feijões Contados, a violência psicológica de que a mãe é alvo acentua-se e só não culmina no homicídio desta, porque o seu instinto de sobrevivência a leva a abandonar a casa, antecipando-se a qualquer desfecho trágico. No último romance da trilogia, Luísa é uma ausência, mas ressurge o tema das fracturas familiares e da desestruturação geradora de violência, neste caso atribuída a outro evento da história portuguesa contemporânea que foi a transição de Macau para a China.

Há nos três romances de Maria do Céu Carvalho, uma galeria significativa de mulheres, todas elas caracterizadas pela resiliência e pela independência em relação a figuras masculinas. Há, em primeiro lugar, as turistas britânicas ricas, representadas de acordo com alguns estereótipos e que levam à desconstrução dos papéis de género. Numa sociedade que é apresentada como profundamente machista (e basta elencar os comentários dos homens e as reacções do protagonista), elas quebram um dos grandes tabus relativas aos papéis de género: desfrutam a vida com prazer e vivem a sexualidade sem complexos, tomando iniciativas atribuídas aos homens. Também as mulheres vindas de Angola evidenciam uma independência que aponta para o papel de transformação de costumes que elas trouxeram à sociedade portuguesa. E no terceiro romance, Maria do Céu Carvalho retrata em Laura uma mulher luso-chinesa, determinada e sem medo, que acompanhada por Júlio, enfrenta as seitas chinesas e reivindica um neto com nacionalidade mista, num desafio a valores tradicionais chineses relativos à família.

Muito diferente da obra de Maria do Céu Carvalho, é a trilogia quase coetânea de Margarida Utne, também publicada na coleção Policial da Caminho: A Morte por um Fio (1997), O Último Comboio para Roma (1998) e Terra Incógnita (2000). Nenhum crime se desenrola em território português e as personagens principais são norueguesas, mesmo quando a acção tem lugar fora da Noruega, o país escolhido para a estreia da autora na ficção criminal. A biografia de Utne, a par do sucesso da ficção policial nórdica nos anos 1990, explicará o privilégio dado à Noruega (onde viveu), bem como o cosmopolitismo dos seus romances. Diz-se nos livros que Margarida Ponte Ferreira (Margarida Utne) viveu em vários países, 
tendo trabalhado no Instituto Norueguês de Política Internacional, nas Nações Unidas em Genebra, em representação de Portugal junto da EU.

No primeiro romance, cujo cenário é a Noruega, estamos perante uma história de crime e suspense na linha de Ruth Rendell, inspirada num caso real, com espaço para uma investigação metódica por parte de um agente da polícia. Na segunda, deslocamo-nos do cenário da Noruega para Itália, e na terceira história, mergulhamos no cenário inóspito da Antárctida, lugar bem incomum no âmbito da ficção criminal.

Tal como na maioria das narrativas de Ruth Rendell, em A Morte por um Fio, o leitor sabe, desde o início, quem é o criminoso e acompanha, com ele, a investigação feita, não excluindo alguma simpatia pelo mesmo. É-nos apresentado como um homem vulgar, solitário, simpático na sua ligação à Natureza e nas relações de solidariedade para com os vizinhos e para com a mulher solitária com quem se cruza numa espécie de chatroom e que virá a persegui-lo. Com perfeito domínio das técnicas do suspense, e dando amplo espaço à introspecção, Margarida Utne constrói uma história densa, em que os papéis de vítima e de agressor não podem ser lidos à luz de questões de género. O homicídio é instigado e levado a cabo conjuntamente pelo homem e pela melhor amiga da vítima, que deseja vingar-se da falta de apoio da amiga numa situação de divórcio e de disputa pela guarda de um filho. Apesar de o criminoso ser capturado graças à investigação diligente e persistente de um agente da polícia, o final da história não provoca qualquer efeito de alívio no leitor. O que persiste é a ideia de um universo dominado pelo individualismo, pela solidão exacerbada pelos meios tecnológicos contemporâneos, e, sobretudo, a ideia da banalização do crime violento, que surge como forma de resolução de conflitos privados e de contratempos no quotidiano.

Bem articulada com o eixo central da narrativa criminal, surge uma narrativa de viagem, que faz do comboio o meio de transporte ideal para a projecção de imagens associadas à Noruega: a neve, os fiordes, os lagos, a pesca e lugares isolados «fora do mundo» propícios a crimes quase perfeitos. Na linha de muitos romances nórdicos, o locus criminalis adquire aqui um papel proeminente.

Nos romances posteriores, a fórmula da narrativa policial combina-se de forma ainda mais acentuada com a da narrativa de viagem, e o segundo romance, o Comboio para Roma, abre ainda espaço à temática amorosa em consonância com o local do crime. Ainda sob o signo de Ruth Rendell, mas também do de Patricia Highsmith (com o tema do duplo, da rivalidade, da chantagem), este romance 
é sobretudo na figuração da mulher que se reconhece a assinatura de Agustina, como no passo: "Ao transitar da mediania da sua infância para a opulência da casa Hamblin, fizera-o já iluminada por essa consciência vivíssima das situações, das atitudes, que existe em todas as mulheres cuja alma, antes de ser feminina, é comediante. Era actualmente o embrião duma grande dama (...)» (p. 17). Ou, neste outro trecho: «- Nada... - disse melancólica. Os homens gostam que as mulheres pareçam às vezes um tanto abstractas e incompreensíveis como um brinquedo a que se deixou de dar corda» (p. 46).

Apesar da brevidade e da linearidade da intriga, há nesta novela um estudo da complexidade das relações humanas, uma fina análise psicológica, despida de sentimentalismo e de moralismo. Não existe neste universo nenhuma representação da mulher como vítima ou inocente; nem há condenação pelo crime por ela cometido. Como em Eugénia e Silvina (1989), a criminosa mata o pai (não biológico, aqui) e fica impune. Mas a inquietação que esta obra desperta não decorre dessa impunidade; antes deriva da ideia da monstruosidade que habita em cada ser humano e que pode emergir a cada momento na luta pela sobrevivência, num paralelismo explícito com o que se passa no mundo animal. «A Natureza cria monstros onde só a monstruosidade representa defesa da própria Natureza...», diz Osmond (p. 65).

A novela Aquário e Sagitário é um excelente exemplo do modo como o recurso à estrutura rígida do policial da genteel tradition, não impede uma grande escritora como Agustina de imprimir a sua cosmovisão na história, deixando a assinatura de um estilo inconfundível, já assinalado por Carlos Quiroga em «Agustina no policial» (1999) - o que o ensaísta entende como não conformidade com a «exigência do género» (p. 102). De facto, não o é, como não o é a descrição sensualista e voluptuosa do interior da mansão ou os efeitos de chiaroscuro criados nesta novela. Mas no decurso da história do género, só os escritores medíocres do policial seguiram as Artes Poéticas de um S.S. Van Dine ou de um R. Knox, e, ao longo dos tempos, os grandes escritores de policiais (como Raymond Chandler ou Ross MacDonald, por ex.), provaram que a intriga (fiction) não é incompatível com uma escrita literária (diction).

Também o romance de Ana Nobre de Gusmão, Delito sem Corpo (1996) - com o qual obteve o prémio «Revelação» da Revista Máxima - faz das relações familiares e dos dramas pessoais de pessoas comuns a sua matéria literária. O título convoca procedimentos policiais bem familiares aos leitores e espectadores de ficção policial e é já, na sua reescrita, uma chave de leitura do romance. Inver- 
tendo a tradição do policial clássico, a morte surge apenas no desfecho da obra, estando ausente qualquer investigação criminal. Delito sem Corpo situa-se no âmbito do thriller psicológico, "policial e sentimental», segundo Helena Vasconcelos (1996: 8), sem recurso a peripécias e a elementos sensacionalistas ou extraordinários, não obstante «o medo» ser um leitmotiv de uma obra marcada por uma atmosfera de suspense, mitigado pelo humor. Transformado em voyeur, o leitor vai acompanhando a viagem (literal e simbólica) entre Portugal e os EUA, de uma mulher, cujos traços mais acentuados são a determinação e a obsessão, e que lhe permitem concretizar o plano de vingança traçado depois de um divórcio não desejado: a desestabilização da nova relação amorosa do ex-marido e a morte deste sem que nenhuma arma letal tenha sido utilizada.

Em 1996, Julieta Monginho, magistrada do Ministério Público, publica o seu primeiro romance, Juízo Perfeito, e as relações com o policial são inevitáveis, não obstante a identificação, nas primeiras páginas, do crime, da vítima, do criminoso e a enumeração dos crimes de que este é acusado pelo Ministério Público: homicídio qualificado, sequestro e porte ilegal de armas. A vítima é a esposa do homicida e a acusação traz para a ribalta o crime da violência doméstica num universo provinciano de valores patriarcais. No entanto, esta revelação inicial ao leitor não dissipa os muitos mistérios e enigmas disseminados ao longo da narrativa e que vão persistir para lá do final (nomeadamente a suspeita de traição e adultério lançada sobre a mulher assassinada). Por sua vez, o jovem juiz Carlos Duarte, protagonista do romance ${ }^{12}$ e potencial investigador do caso em toda a sua complexidade, declina o papel de detective de modo auto-depreciativo, não obstante as incongruências que capta no depoimento de um agente da GNR:

Porque não fazendo-se transportar num carro branco? (...) Por que carga de água estaria a entrar em devaneios de romance policial? Valeria a pena tirar a limpo que jornal era, de quando, se estava inteiro, em que sítio da sala estava? Que diriam os seus colegas de colectivo se interrompesse para levantar a questão? Por certo que ele andaria a ler muitos policiais, o que até nem é o caso, não é género que o empolgue. (...) E valeria a pena estar inquieto? «Duarte, o detective». Ainda por cima este epíteto pareceu-lhe de mau gosto familiar. Tentará esquecer o episódio até ao fim da sessão. (p. 52, itálico meu)

\footnotetext{
${ }^{12}$ Sobre Juízo Perfeito, escreve Mafalda Ferin Cunha: «torna-se evidente que este romance é muito mais a história de um julgamento e da evolução interior de um juiz do que a história da investigação dum homicídio» (Cunha 2002: 288).
} 
Esta negação do juiz em clarificar alguns dos enigmas da história (mesmo quando é instado a fazê-lo pela irmã da vítima) traz consigo uma metamorfose do modelo do policial. Em vez da história de outras investigações, temos a história do julgamento do crime, a qual recupera e reinventa as histórias, cronologicamente anteriores, da investigação, do crime, e da relação do casal. Com a obra Juízo Perfeito, Julieta Monginho apresenta ao leitor um «romance de tribunal» (court novel), sem tradição no panorama das letras portuguesas, que se inicia no ponto onde muitos romances policiais terminam e onde não ousam penetrar: o julgamento do criminoso (e/ou arguido) e os meandros do tribunal. Identificado que está o assassino («Quem?»), procura-se averiguar em tribunal, perante as provas e o confronto de testemunhas, se se trata de um crime agravado, premeditado ou não. ${ }^{13} \mathrm{E}$ decide-se qual a pena a aplicar ao homicida.

Trata-se, assim, de um romance inovador, com uma forte componente dramática, que põe em diálogo o discurso da Lei (e a letra em textos judiciais transcritos) e o discurso da Literatura, quase ausente na forma romanesca em Portugal. Este diálogo é capitalizado pela acentuada vertente metaficcional e autorreflexiva da narrativa, que desvela analogias hermenêuticas e pela encenação de versões e de perspectivas que o cenário de um tribunal propicia. Em cena, e de um ângulo inesperado, uma reflexão sobre o poder da linguagem e sobre o silêncio (no feminino) como forma de resistência.

Juízo Perfeito é, provavelmente, o romance do séc. XX a debruçar-se de forma mais aprofundada sobre o drama da violência doméstica em Portugal, em contexto rural, e sobre a sua minimização por parte da comunidade em geral e por parte dos juízes. Uma obra sobre o hiato entre a Lei e a sua aplicação prática, que «retrata» pela via ficcional (a partir de um lugar chamado Vila Seca) uma sociedade patriarcal, machista, atávica, análoga à descrita por Clara Pinto Correia, uma década antes, em Adeus, Princesa. Que ousa tocar no intocável, sem atitude judicativa ou moralizante: a suavidade da pena não é (apenas) atribuída ao «sistema», ou ao Código Penal, mas a juízes do sexo masculino, que têm uma atitude de cumplicidade de género para com o agressor, tal como se apreende no Acórdão transcrito que encerra o caso e nas palavras de simpatia que precedem a sua elaboração: «- Claro, coitado do homem, não vamos considerar que já tinha pensado em matar a mulher antes. Vamos dizer que decidiu matá-la nesse momento»

\footnotetext{
${ }^{13}$ Remeto para o estudo pormenorizado deste romance em «Julieta Monginho: entre o som e os silêncios» in Revista Faculdade de Letras. Línguas e Literaturas, II Série, vol. XXII, Porto, 2005, pp. 549-579. Texto originalmente apresentado no ciclo Vozes e Olhares no Feminino, Porto, Capital Europeia da Cultura 2001.
} 
(p. 180). No final, torna-se evidente que a palavra da Lei e da Justiça está ao serviço de uma sociedade falocêntrica e de valores ancestrais profundamente enraizados na sociedade portuguesa.

Importa dizer, por último, que a novidade deste romance reside também na destruição de dicotomias tradicionais, da polarização total entre um universo de valores masculinos e outro de valores femininos. Caberá a um homem (delegado do Ministério Público) fazer as alegações mais veementes (que lhe merecem dos juízes a comparação com «uma feminista das mais encarniçadas» (pp. 178-179). Veja-se um exemplo desses argumentos:

Os motivos da sua atitude há que buscá-los a uma vaga sensação de traição que na verdade não existia e só ele imaginou, e à obsessão de negar à mulher qualquer possibilidade de vida própria para além da que ele, na sua suposta autoridade, consentisse. Quis conformá-la à sua própria ideia de que uma esposa nada mais tem de desejar que a submissão ao poder do marido e matou-a por sentir que ela conseguia escapar ao seu domínio. Nos tempos de hoje, à entrada do século XXI, nada pode justificar semelhante atitude. (p. 166)

Até 1995, os romances que em Portugal foram publicados como «policiais» ficavam à porta do tribunal, em conformidade com uma longa tradição do género (quer na linha dedutiva quer na da ficção hardboiled norte-americana). Com Juízo Perfeito transpusemos essa barreira para nos confrontarmos com o engendramento de novos mistérios no espaço do tribunal a partir de jogos entre a verosimilhança e a verdade. Como se esta obra fosse uma espécie de desvelamento da utopia subjacente ao género policial: uma bem-sucedida investigação policial não significa a condenação do criminoso nem a contenção do crime.

\section{Século XXI}

O século XXI inicia-se com a publicação de uma obra invulgar no panorama literário português contemporâneo que nos leva a transpor outra fronteira - as portas do Instituto de Medicina Legal - e a colocar o cadáver bem no centro da história. Trata-se de Este é o Meu Corpo (2001), de Filipa Melo, romance de estreia da autora e já traduzido para várias línguas. Os dados para a construção de um romance policial estão lançados desde o início: o aparecimento do cadáver de uma mulher esquartejada, sem qualquer identificação, leva uma equipa de investigadores à cena do crime, ao que se segue a autópsia do cadá- 
ver detalhadamente descrita e comentada pelo médico-legista. À revelia de qualquer inquirição policial (apenas referida), e da própria autópsia, o criminoso, um homem comum, casado, revelará ao leitor alguns pormenores relativos ao homicídio não premeditado da amante (pela asfixia) e sugere o fim da relação como móbil do crime.

Embora várias vidas sejam narradas e entrelaçadas na narrativa (o caso de um recém-nascido abandonado num hospital, a história do avô da criança, o ciclo vida e morte), a maioria dos capítulos centra-se na morgue e nos actos do médico-legista, que vai gravando cada gesto, num solilóquio perturbador em que o discurso técnico (com termos e citações de manuais de Tanatologia) se entrelaça com um discurso amoroso sussurrado ao cadáver da mulher. Não há, no entanto, qualquer cedência à goticização da morte e ao horror (uma das tendências da ficção criminal contemporânea) nem a narrativa cai no tratamento sensacionalista dos actos nem no exacerbamento de emoções, como em grande parte do romance nórdico. Se algo surpreende o leitor é uma espécie de understatement (na neutralidade judicativa) e de anestesia emocional perante a violência bárbara de que a mulher foi vítima (desfiguração e arrastamento no alcatrão), dela restando, como se diz logo na abertura, sem eufemismos, «uma estranha massa de órgãos, veias, músculos e ossos» (p. 34).

O romance de Filipa Melo coaduna-se com as transformações científicas e tecnológicas da investigação criminal no séc. XX e XXI, que trazem para primeiro plano a determinação do $\mathrm{ADN}$, a medicina forense, as equipas inter-e multidisciplinares da Polícia (tão recorrentes nas séries televisivas), relegando para a esfera do utópico e do passado o mito do detective solitário em demanda da verdade. O mundo contemporâneo de Este é o meu corpo é um mundo análogo ao descrito por Patricia Cornwell, mas nele não há lugar para uma patologista como Kay Scarpetta. A médica-legista lusa que aparece no incipit da narrativa emociona-se perante a barbaridade do crime e pede a um colega que se ocupe da autópsia, pois «ainda é capaz de chorar ao olhar para um corpo torturado com especial violência» (p. 32). No entanto, a leitura do romance não fundamenta a ideia de que se trata de um ofício impróprio para mulheres; a atribuição do trabalho de autópsia a um homem serve a criação de uma narrativa complexa, que gradualmente transforma o médico-legista num duplo do assassino.

O médico-legista é um apaixonado pelo seu ofício, que se auto-apresenta como «um caçador de verdades», que decifra e interpreta os sinais de qualquer corpo, comparado este a romance policial: «Vai-nos dando pistas, ocultando 
outras, sempre mantendo o suspense» (p. 21). No seu discurso, afirma-se enfaticamente a supremacia da ciência face a outras formas de conhecimento; defende-se a supremacia da medicina forense («dos recados dos mortos» p. 22) face à actividade dos juízes (à «arbitrária justiça dos homens»; idem), apontando-se o dedo à fragilidade das provas empíricas e circunstanciais ou dos testemunhos com que os juízes trabalham. São vários os sinais de megalomania presentes no ostensivo auto-retrato que vai traçando e que revelam um indivíduo introvertido, associal, «propenso a depressões», que desde sempre teve uma atracção mórbida pelos mortos. Se dúvidas houvesse na identificação do médico-legista com o criminoso baseada na sintaxe textual (vejam-se os nexos entre os capítulos nucleares 9, 10 e 11) e do léxico comum a ambos - «Virar do avesso», «rasgar»e «penetrar», por exemplo - elas dissipar-se-iam perante declarações deste género: «Poderia ter sido eu a deixá-la neste estado. Podia ser eu o criminoso. A ideia não me sai da cabeça. Agrada-me o tremor que ela me traz às mãos. Este é um dos meus mortos. Eu pertenço a esta história» (p. 36). Por sua vez, a recorrente analogia entre o desmembramento do cadáver e a culinária culmina numa imagem de canibalismo: «No teu caso, o coração não mente. Desculpa-me a obscenidade: está tão são que eu podia jantá-lo hoje» (p. 105).

Uma das hipóteses explicativas (indo para lá da leitura positivista da supremacia da matéria e da consequente equivalência de todos os corpos - de animais e de humanos) leva-nos de volta à questão da violência e da violentação: agora legitimada, «legal», transformada num acto que tem tanto de científico como de artístico (enfatiza-se, várias vezes, a dimensão estética do corpo e da própria autópsia). Ou de herético, numa dessacralização do acto litúrgico da eucaristia. O universo de Hannibal Lecter está simultaneamente muito próximo e muito longe, pois se a degustação do corpo não passa de uma sugestão, há claramente um ego canibalesco, que se compraz num «diálogo morto» (p. 128) com cadáveres através dos quais se exorciza o medo da morte. Estamos perante um romance de duplos, de réplicas, de desdobramentos, de reflexos e, transferências várias (com referência explícita à prática da psicanálise), como já assinalou Eduardo Prado Coelho no ensaio «Aquele que fala com os Mortos» (Público, 27 Out. 2001).

Em 2011 é publicado 0 caso do Cadáver Esquisito, livro que resultou da novelização de programa prévio de rádio (Projecto Alcântara). A composição foi feita na linha do cadavre exquis surrealista. No total, o livro (que acrescenta um capítulo à narrativa na rádio) contou com textos de onze escritores e a colaboração de um gráfico. Participaram: Afonso Cruz, Jacinto Lucas Pires, Joana Bértholo, 
Luís Caminha, Miguel Castro Caldas, Ondjaki, Patrícia Portela, Paulo Condessa, Pedro Medina Ribeiro, Rita Taborda Duarte, Sandro William Junqueira e Maria João Lima no grafismo. A edição e produção (Prado) foram de Isabel Garcez, Helena Serra, Patrícia Portela e Pedro Pires. Estamos perante uma experiência que merece um estudo aprofundado, pois podemos entendê-la como um ponto de chegada (não esgotado) de caminhos abertos pela literatura policial: a desvalorização da figura romântica do autor e a importância do trabalho de parceria e de cooperação ${ }^{14}$ que as novas tecnologias e as redes sociais vieram estimular, sem que o seu valor esteja suficientemente reconhecido; a complementaridade e reversibilidade não metafórica dos papéis de escritor e de leitor; o entretenimento aliado a um experimentalismo cujo valor estético pode ser muito variável, e onde «o processo é mais importante do que o resultado».

Em 2012 , com reedição em 2018, é publicado o romance de Ana Saragoça, Todos os Dias são Meus (com prefácio de Mário de Carvalho) que se estrutura a partir da investigação policial de uma mulher morta (aparecida num elevador) por agentes da PJ, sem que alguma importância seja dada aos investigadores em si mesmos. ${ }^{15} \mathrm{~A}$ visibilidade e a atenção recaem nos moradores de um prédio, nas suas vidas quotidianas e banais, nos seus segredos, muitos deles revelados pela porteira do prédio. A localização de um crime no espaço comunitário e fechado de um prédio (de que o romance L'Assassin habite au 21, de Stanislas-André Steeman é paradigma) revela-se extremamente fecundo para um inquérito a um microcosmos de relações interpessoais em cenário urbano marcado pela solidão e incomunicabilidade.

Não obstante a forte presença das mulheres no romance policial nas duas últimas décadas do séc. XX, é só no primeiro decénio do séc. XXI, e no mesmo ano de 2013, que são criadas as primeira mulheres detectives da ficção policial em Portugal: no romance Morte com Vista para o Mar, do jornalista Pedro Garcia Rosado, e no romance Colecionador de Erva, de Francisco José Viegas. Depois de vários thrillers, desde 2004, Pedro Garcia Rosado escreve a trilogia Morte com Vista

\footnotetext{
${ }^{14} \mathrm{O}$ modo como o policial - em tradução - contribuiu para a agregação de vários artistas e de vários ofícios, catalisando vários trabalhos de parceria (desde a tradução ao grafismo) foi já objecto de tratamento na minha tese de doutoramento (em 2007), e retomado de forma mais desenvolvida, focado no estudo de antologias, em «Mystery/Detective Fiction. Anthologies in Portugal (Late 1940s-1950)», do livro The Anthology in Portugal. Translation and the Margins, publicado em co-autoria com Margarida Vale do Gato e Patricia Baubeta, London, Peter Lang, 2013, pp. 229-414.

${ }^{15}$ Ver entrevista à autora em https://www.delas.pt/ana-saragoca-a-autora-de-todos-os-dias-sao-meus-em-entrevista/conversa-delas/410294/
} 
para o Mar (2013), Morte na Arena (2013) e Morte nas Trevas (2014), uma série que tem a particularidade de apresentar duas mulheres dedicadas à investigação criminal: Patrícia Ponte, inspectora-coordenadora da Polícia Judiciária, responsável pela inquirição de crimes de morte, e, num segundo plano, a repórter criminal, Filomena Coutinho, cujo trabalho de relato de crimes põe a nu as fugas de informação da Polícia Judiciária, ao mesmo tempo que inscreve no romance a vertente de metaficcionalidade que caracteriza parte da ficção policial contemporânea. A inclusão de duas mulheres permite também ao autor tecer uma trama em que questões passionais se enredam com questões profissionais, reforçando a visão da sociedade portuguesa como um meio fechado, endogâmico, onde as relações de parentesco, de amizade e proximidade entre indivíduos e instituições, facilmente conduzem à corrupção, ao tráfico de influências e a crimes de toda a natureza.

Os romances de Garcia Rosado têm como quadro de referência os mais violentos autores da ficção hardboiled, mas contemplam também os processos de modernização da investigação policial: o ADN, o papel dos computadores, o trabalho em equipa e, o que aqui nos interessa, a integração de mulheres em equipas policiais e em lugares de chefia. Assim, em Morte com Vista para o Mar(2013), emerge no panorama literário português a primeira detective no mundo da ficção policial: Patrícia Ponte, inspectora-coordenadora da Polícia Judiciária. No entanto, no primeiro romance, há uma quase invisibilidade da mulher inspectora, podendo essa quase ausência ser atribuída ao seu lugar de chefia, situado fora da rua; o que se releva, é o lado da vida pessoal (segundo casamento, a tensão com o ex-marido). O seu papel limita-se a entregar dossiês para que o ex-marido os estude. Patrícia Ponte é apresentada como uma mulher determinada, ambiciosa, capaz de conciliar a carreira profissional com a vida familiar. Voltou a casar, tem dois filhos e está grávida. Em casa, as tarefas são repartidas e tudo parece perfeito. Mas enfrenta com relutância as autópsias e sofre de vertigens, fragilidades essas pouco compatíveis com o ofício que tem. São vários os passos em que são referidas as náuseas que a visão dos cadáveres lhe provoca, agravadas também pela sua terceira gravidez. Em Morte na Arena intersectam-se imagens da cozinha com a investigação criminal:

Patricia pensa, de repente, em frangos e perus trinchados à mesa e leva uma mão à boca, tentando reprimir a náusea que a ameaça (...). A inspectora respira fundo. Gosta do que faz e acredita numa promoção ainda antes de chegar aos quarenta anos, e já falta pouco, mas preferia não ter de lidar com cadáveres. Os crimes vio- 
lentos impressionam-na sempre mas a passagem pela Secção de Homicídios é fundamental para a sua carreira. (p. 31)

As pesquisas no terreno são levadas a cabo pela equipa que dirige, e que não parece ter problemas com a chefia no feminino, mas é ao ex-marido e ex-inspector da Polícia Judiciária, Gabriel Ponte, que se deve grande parte do sucesso das suas investigações. A dificuldade em este acatar ordens da ex-esposa parece dever-se mais ao seu carácter indomável e de insubordinação (que o conduziu à reforma) do que propriamente a uma qualquer atitude machista. Os actos heróicos da inspectora (como quando salva o ex-marido nas catacumbas de Lisboa, em Morte na Arena) não são suficientes para retirar o protagonismo a Gabriel Ponte - pelo menos a nível editorial. Aliás, os dois últimos romances têm como subtítulo «As Investigações de Gabriel Ponte» e a etiqueta: «Aviso Cenas Chocantes». O enquadramento legal criado desde o início é assim destruído nesta colaboração ilegal, mas aparentemente pacífica e necessária, entre as instituições e um membro já fora da instituição a quem nada é vedado. O esbatimento do papel da investigadora tanto pode ser atribuído à ideia da ineficácia e limitações legais das instituições como à própria gravidez. Mas é essa gravidez (i.e., o corpo da mulher como limitação) que servirá de expediente para a sua eliminação do terceiro romance, Morte nas Trevas. Patrícia Ponte não é mais do que um nome, com referência pontual (ao parto, por ex.), passando a jornalista Filomena Coutinho a ter mais destaque, mas como adjuvante de Gabriel Ponte, sempre a braços com crimes horrendos, transversais a todos os sectores da sociedade portuguesa (incluindo altos magistrados), e agora também com a perseguição de um inspector da Polícia Judiciária.

Um mês depois da publicação de Morte com Vista para o Mar, é publicado O Colecionador de Erva (2013), de Francisco José Viegas, que amplia e renova a equipa de detectives liderada pelo inspector Jaime Ramos. Assim, a «família» do mais famoso inspector português passa a incluir duas mulheres detectives: Dulce dos Santos e Olívia (Maria Olívia Xavier da Costa), a inspectora da polícia que vai adquirir maior protagonismo nesta obra. Dulce dos Santos é apenas um esboço embrionário de detective, sem maturação. Mas, embora desfocado, o retrato combina traços dos estereótipos femininos com facetas que apontam para a superação desses mesmos estereótipos: Dulce é uma mulher triste, apagada, maternal, cuidadora da família, mas que a dado momento opta pelo seu trabalho e autonomia, obrigando-se, por motivos deontológicos (a dependên- 
cia do irmão da droga), a abandonar a sua terra de origem (o Alentejo) para se manter na instituição policial (muda para o Porto).

Já Olívia, uma minhota de cabelos loiros, é uma personagem mais complexa, que cedo desafia os papéis de género e que tem direito a uma biografia mais completa:

fora guarda-florestal aos dezanove anos, mãe aos vinte, licenciada em direito aos vinte e seis num curso noturno e inspetora da polícia desde os vinte e oito, depois de um divórcio tumultuoso aos vinte e de um ferimento no ombro esquerdo (a bala entrou pelo ombro e furou a omoplata) há dois anos, digamos aos trinte e oito. (p. 30)

Há uma dívida explícita para com Lisbeth Salander e há signos inconfundíveis dessa filiação: a moto, o capacete, o blusão de cabedal, os cigarros, a bissexualidade. A indumentária indicia a liberdade e a dívida para com uma mitologia norte-americana: «vestia como se estivesse sempre pronta para conduzir uma moto imaginária pela estrada do litoral, recortada frente à luz do mar como uma figura de papel de lustro, numa espécie provinciana de Easy Rider» (p. 34). Como Salander, preza a autonomia, a independência e a liberdade; daí a recusa da segurança de um trabalho de funcionária pública, com oito horas diárias, numa secção de apoio jurídico e a opção pela investigação no terreno. Através de Olívia, Viegas introduz o tema da violência doméstica no casamento, mas reescreve, com uma nota humorística, as narrativas habituais de violência e de vitimização da mulher: alta e musculada, Olívia defende-se do ex-marido a murros e pontapés, sem necessidade de recorrer a qualquer arma, o que merece de Jaime Ramos o seguinte comentário: «Tu bateste-lhe com dignidade. Usaste os punhos e o pé. Ele não vai apresentar queixa. Seria uma vergonha para a tribo» (p. 33). Talvez por causa da sua vida pessoal, Olívia surge no livro de contos $A$ Poeira que cai sobre a Terra e Outras Histórias de Jaime Ramos (2016) descrita como «inspetora especializada em crimes sexuais, perseguição a tarados, retratos psicológicos, maridos traídos ou violentos, mulheres perseguidas»(Viegas 2016: 26). Sobre o seu papel materno, fica no ar a ideia de que declinou o papel tradicional de mãe protectora, deixando o filho crescer no meio dos pescadores e a cometer pequenas infracções, entendendo-as como parte de um processo de aprendizagem. Apesar do discreto respeito do chefe (a quem chama de «Professor»), Olivia desempenha o papel de adjuvante e assistente, não tendo qualquer papel de proeminência: Ramos não lhe permite participar nos inquéritos principais, 
tugal contemporâneo: o desemprego, a falta de horizontes para os jovens, o poder concentrado na capital, as assimetrias entre Lisboa e o resto do país, a burocracia, as mesquinhas rivalidades laborais, a rigidez nas relações hierárquicas, a tirania dos títulos académicos, a alienação de certos intelectuais, e, sobretudo, uma relação com a História que é da ordem do deslumbramento, sem atitude crítica.

A grande novidade de Crimes Inocentes reside na criação de uma detective mulher, que descobre, no decurso da história, a sua vocação detectivesca, decidindo tornar-se uma profissional. Rosarinho é retratada como uma jovem luso-belga, filha de emigrantes portugueses em Bruxelas, e que, contra a corrente da emigração do período da Troika e do pós-Troika, deixa a Bélgica e os pais e procura trabalho em Portugal, depois de ter concluído o curso de História. A ligação a Bruxelas activa de imediato uma relação com Poirot que se cruza com a inspiração em Lisbeth Salander. Tal como o detective belga, pragueja em francês e utiliza muitos bordões nessa língua. Leitora de policiais, Rosarinho não dispensa o seu andróide e os recursos da Internet, mas são as suas células cinzentas e o seu distanciamento crítico em relação a Portugal que lhe permitem levar a cabo, com sucesso, uma investigação em que a polícia fracassa. O grande mérito de Rosarinho consiste na capacidade de conciliar uma visão microcóspica da realidade com a visão telescópica, i.e., panorâmica e contextual do mundo à sua volta.

Gabriel Magalhães cunha para ela uma designação inovadora, ao referir-se-lhe como «novel investigadora» (p. 312), sublinhando deste modo a novidade da sua criatura e acentuando o paralelismo entre a investigação criminal e a investigação histórica. Para um maior efeito de verosimilhança, na atmosfera de farsa criada, em vários momentos se refere a licenciatura de Rosarinho e o mestrado sobre criminologia no Estado Novo.

Num desafio a estereótipos de género, Rosarinho é uma jovem pragmática, orientada para a solução de problemas concretos, e as suas qualidades salientam-se no contraste com as do namorado, um investigador pós-Doc., dedicado ao estudo sobre a literatura decadentista e contaminado pelo seu objecto de estudo. Vasco é uma personagem alienada da realidade em seu redor, e, quando não faz «investigação científica», dedica-se aos trabalhos domésticos e a cuidar de uma cadela.

Em Prefácio à sua Aventura Inquietante (1959), José Rodrigues Miguéis criticava os preconceitos da sociedade portuguesa em relação a formas literárias hedonistas e argumentava que um divertimento também poderia ser sério. Estas 
palavras aplicam-se com toda a propriedade ao romance de Gabriel Magalhães. Através da protagonista de Crimes Inocentes, uma historiadora com uma visão anti-heróica de Portugal e da sua História, o autor traz para o universo de ficção importantes problemas do mundo contemporâneo, desde o exacerbar dos nacionalismos por toda a parte ao imperativo de os portugueses procederem a uma revisão da sua História, numa invectiva ao abandono de leituras parciais e monolíticas. É pela sua voz que surge a crítica porventura mais negativista da expansão portuguesa na ficção portuguesa, tanto mais que expressa em termos claros, sem filtros:

- E atenção: nós, portugueses - dizia ela - com a nossa mania dos brandos costumes, fizemos tanto mal como os outros. Levámos seis milhões de escravos das costas de África para o Brasil. Seis milhões! Arrepia pensar que, se tivermos em conta este número, empatamos com a Alemanha do holocausto, que matou seis milhões de judeus. (p. 371)

Não se revendo nos feitos lusitanos, Rosarinho é uma voz crítica arrojada que veicula uma visão do mundo hostil a qualquer forma de nacionalismo e patriotismo, deixando no ar questões incómodas: «Já imaginaram quantas pessoas morreram na Primeira Guerra Mundial arrastadas pelo magnetismo maldito das bandeiras?» (p. 370). Cidadã do mundo, bilingue, criando pontes entre o país semiperiférico onde escolheu viver e a capital política da Europa, onde permanecem os pais, Rosarinho relembra e amplia a lição pessoana: «Ser de várias pátrias ajuda-nos a conservar a lucidez e a decência»(p. 374).

Há assim uma apologia da identidade dupla e plural de muitos cidadãos do mundo do século XXI. A questão da identidade atravessa toda uma narrativa de ambições totalizantes que abrange um arco temporal vastíssimo da história de Portugal (da expansão portuguesa passando pela ditadura do Estado Novo e conduzindo-nos até ao presente) e que, situando a acção na capital, abrange igualmente a geografia do interior de Portugal - ou pela mímica dos sotaques e idiossincrasias de personagens a viver em Lisboa (mas migrantes de diversas regiões de Portugal) ou pela narrativa de uma delirante viagem à Covilhã.

Se Rosarinho do Amaral continua ou não a sua atividade de detective não sabemos. Mas sabemos que neste romance de Gabriel Gonçalves, ela é uma voz de denúncia de problemas mundiais, cuja visão não se circunscreve ao espaço de Portugal. Questionando a noção de crime, Rosarinho deixa um repto para que vejamos para lá das fronteiras nacionais: 
- São os Estados. Os países. Sim, os países, as nações. Essa coisa a que chamamos pátrias: o maior assassino que existe». E continua a discorrer sobre a história da humanidade (...). E, quando se aplica a pena de morte, uma nação que tenha essa lei pode fazê-lo sem qualquer consequência. (...) Lapida-se uma mulher adúltera num país árabe, enterra-se a desgraçada no chão e arruma-se com a pobre mulher às pedradas, sepultando-a por baixo de calhaus. Não é crime. Tudo legal. (p. 370)

A formação universitária de Rosarinho em História investe de alguma verosimilhança as suas dissertações e a crítica revisionista que faz da História de Portugal, mas Rosarinho do Amaral, como detective amadora, é uma criatura anacrónica, relativamente às tendências da ficção policial de finais do séc. XX e XXI. Como se disse, a partir de meados do séc. XX, a forma dominante da ficção policial é o que em Inglaterra responde pela designação de «police procedural» ou de «police novel». Ou seja, o tipo de narrativa com equipas de agentes da polícia, que investigam seguindo protocolos, e se apoiam na tecnologia da detecção, desde as ciências forenses a outros meios científicos.

Sendo irrealista e utópica, esta imagem de uma jovem oradora empenhada em abalar imagens sedimentadas e ficções colectivas, não deixa de projectar a imagem de uma «novel» mulher, com protagonismo na defesa de um mundo mais justo, sem preconceitos e sem fronteiras. Uma projecção menos utópica do que pareceria, tendo em conta a mobilização de milhares de pessoas (jovens e não jovens) por parte de uma activista como Greta Thunberg.

\section{Considerações finais}

No ensaio referido em Prefácio, «From Enigmas to Emotions: the Twentieth-Century Canonization of Crime Fiction» (2013), Maurizio Ascari sustenta a tese de que bem no cerne do policial contemporâneo encontramos emoções não enigmas intelectualizados. Para Ascari, esta é, definitivamente, a Era do Thriller («The Age of the Thriller») e a literatura escandinava é um exemplo paradigmático desta orientação da ficção policial/criminal. Como o autor argumenta, as emoções têm sido sistematicamente exploradas nestes horizontes geográficos em obras quer de autoria masculina quer feminina, pela tematização de traumas, de crimes sexuais, de histórias horrendas de extrema violência exercidas sobre as mulheres e sobre grupos sociais vulneráveis, havendo ainda, em muitos autores, a articulação entre máfias do presente e crimes e criminosos nazis. A 
tudo isto poderíamos acrescentar o facto de muitas personagens nestas narrativas serem crianças ou jovens expostas a grande sofrimento, o que exponencia a ansiedade do leitor. Este tipo de narrativas, que vai ao encontro do espírito dos tempos - uma era de emoções -, não se circunscreve aos romances nórdicos; encontramo-las no chamado narco-policial (de romances de Elder Mendoza) ou nos romances hiperrealistas de um autor como Rubem Fonseca.

Sendo difícil discordar a priori da abordagem de Ascari do policial contemporâneo, que vem complementar outras teses sobre a importância que a vida privada do/a detective passou a ter (em processo introversivo) nas narrativas policiais, ou sobre a exaustiva exploração de jogos metanarrativos, e, sobretudo, sobre a ideia de policial como reduto de uma literatura realista de crítica social, é com alguma surpresa que verificamos a quase inoperância da tese de Ascari, quando nos debruçamos sobre as obras de autoria feminina atrás estudadas tomando em devida conta que a maioria se situa num limiar, reticente a rótulos taxinómicos. A aplicarmos a teoria de Ascari, teríamos de nos voltar para romances de autoria masculina, elegendo, de entre as a obras abordadas, os thrillers de Pedro Garcia Rosado (e outras não abordadas, como os romances em português de Robert Wilson, a explorar de forma sensacionalista, crimes sexuais). Nenhum romance de autoria feminina parece desencadear fortes reacções somáticas nos leitores, nem eles interpelam directamente as suas emoções.

Feita a descrição e interpretação individual das obras recenseadas, resta-nos apresentar algumas conclusões, que serão, obviamente, passíveis de revisão mediante um estudo comparativo de grande fôlego com obras de autoria masculina dos finais do séc. XX e XXI (comparação que se fez, sempre que possível, mas não textualizada). De forma sumária e sistematizada, são estes os traços mais relevantes do corpus ficcional estudado de autoria feminina (as obras de autoria masculina contempladas contêm já conclusões mais definitivas):

- Tendência forte para a desconstrução da estrutura do policial, com a equação do impulso para investigar, frustrando, de seguida, as expectativas dos leitores - o que explica, em parte, a quase ausência de serialidade romanesca (predominam as autoras de romance único);

- Jogos de metaficcionalidade mais frequentes do que nos romances de autoria masculina de finais do séc. XX e XXI (O Pequeno Mundo e O Defunto Elegante são o expoente máxima dessa prática e Adeus, Princesa é a grande excepção a esta tendência pós-moderna). Há nas obras de autoria masculina fórmulas mais realistas e mesmo hiperrealistas; 
- Forte cepticismo epistemológico, que se traduz em ironia, humor negro e desconfiança em relação à própria linguagem;

- Apesar de formas embrionárias, ausência de detectives femininas ou masculinas criadas por escritoras - o que decorre, entre outras explicações possíveis, do cepticismo e dos jogos de metaficcionalidade suprarreferidos. (Na escrita de policiais de autores masculinos, mais condicionados pelo princípio da verosimilhança, há a criação de vários tipos de detective, privilegiando-se as profissões de jornalista e de polícia);

- Descentramento geográfico da capital portuguesa, com narrativas que tendem ao regionalismo e outras ao cosmopolitismo;

- Redução da escala de observação e do objecto efabulado, que se traduz num interesse acentuado pela esfera familiar e do privado, com relevo para crimes de violência doméstica; mais do que a violência aliada à corrupção política, a instituições e a empresas, as obras estudadas privilegiam as ligações familiares e os dramas pessoais;

- Desinteresse pela descrição da violência em si mesma e por matéria sensacionalista, mesmo quando se trata de crimes de sangue. Nalguns casos, como vimos (Adeus Princesa, Casa Eterna, Esta Noite sonhei com Brueghel, Litoral: Ara Solis) a existência de crime (a força propulsora da indagação) nem sequer se confirma;

- Contenção e sobriedade no tratamento da morte (mesmo quando o cadáver é dissecado «em directo» perante os leitores, como em Este é o meu Corpo);

- Articulada com a vertente metanarrativa de muitas obras, a atribuição de uma maior importância ao papel do leitor e à sua interacção com o texto, em sintonia com as múltiplas possibilidades a explorar do mundo digital;

- Por último, há que salientar os trabalhos de parceria na produção literária, com a consequente dessacralização da figura do Autor. Neste domínio, é de relevar a colaboração de Mário de Carvalho em vários projectos e também de Abel Barros Baptista. Nalguns pontos, os trabalhos colectivos produzidos afirmam-se contra a literatura «elevada», em textos que reinventam espécies como o folhetim oitocentista, numa zona de contra-cultura que desafia conceitos e teorias românticas vigentes no panorama literário português.

Talvez o corpus literário aqui apresentado fique muito aquém do que realmente existe e que muitas obras "policiais» de autoria feminina não tenham merecido até agora a atenção da crítica (nem jornalística nem académica); talvez se situem num plano de invisibilidade e de anomia que este estudo não conse- 
guiu redimir. Mas, ficam, decerto, em aberto muitos caminhos para futuras e mais produtivas investigações, com a necessária actualização bibliográfica.

\section{Obras seleccionadas}

BAPTISTA, Abel Barros; GOMES, Luísa, Costa (1996), o Defunto Elegante, Lisboa, Relógio d’Água.

BESSA-LUÍS, Agustina (1995), Aquário e Sagitário, Porto, Livraria Civilização Editora. BOTELHO, Fernanda (1987), Esta Noite sonhei com Brueghel, Lisboa, Contexto.

CARVALHO, Maria do Céu (1994), Intermediários, Lda., Lisboa, Caminho. (1995), Feijões Contados, Lisboa, Caminho. (1998) Macau... bye, bye!, Lisboa, Caminho.

CARVALHO, Mário de; CORREIA, Clara Pinto (1986), E se tivesse a Bondade de me Dizer Porquê, Lisboa, Relógio d’Água.

CORREIA, Clara Pinto (1988), Adeus, Princesa [1985], 3.ㄹ ed., Lisboa, Relógio d'Água.

CORREIA, Hélia (1991), A Casa Eterna, Lisboa, Relógio d’Água. (1988), A Fenda Erótica, Lisboa, O Jornal.

CRUZ, Afonso et alii (2011/2018), 0 Caso do Cadáver Esquisito, Editorial Prado.

GOMES, Luísa Costa (2002), o Pequeno Mundo [1988], Lisboa, Assírio \& Alvim.

GUEDES, Maria Estela (1984), Crime no Museu de Philosophia Natural, Porto, Guimarães \& Eds. GUSMÃO, Ana Nobre de (1996), Delito sem Corpo, Lisboa, Editorial Presença.

MAGALHÃES, Gabriel (2018), Os Crimes Inocentes, Lisboa, Planeta.

MELO, Filipa (2001), Este é o Meu Corpo, Lisboa, Sextante.

MONGINHO, Julieta (1999), Juízo Perfeito (1996), 3.ㄹ ed., Lisboa, Dom Quixote.

PEREIRA, Ana Teresa (1989), Matar a Imagem, Lisboa, Caminho. (2016), Karen, Lisboa, Relógio d’Água.

RAMOS, Wanda (1991), Litoral: Ara Solis, Lisboa, Caminho.

REIS, Jorge (1961), Matai-vos uns aos Outros, Lisboa, Prelo.

ROSADO, Pedro Garcia (2013), Morte com Vista sobre o Mar, Amadora, Topseller. (2013), Morte na Arena. As investigações de Gabriel Ponte, Amadora, Topseller. (2014), Morte nas Trevas. As investigações de Gabriel Ponte, Amadora, Topseller.

SARAGOÇA, Ana (2018), Todos os dias são Meus [2012], Planeta.

UTNE, Margarida (1997), Morte por um Fio, Lisboa, Caminho. (1998), Comboio para Roma, Lisboa, Caminho. (2000), Terra Incógnita, Lisboa, Caminho.

VIEGAS, Francisco José(1989), Crime em Ponta Delgada, Lisboa, Publicações Europa-América. (2013), o Colecionador de Erva, Porto, Porto Editora. 
(2016) A Poeira que Cai sobre a Terra e outras histórias de Jaime Ramos, Porto, Porto Editora. (2019), A Luz de Pequim, Porto, Porto Editora.

\section{Bibliografia teórico-crítica seleccionada}

ASCARI, Maurizio (2013), «From Enigmas to Emotions: The Twentieth-Century Canonization of Crime Fiction», in Clues: A Journal of Detection (McFarland \& Company), Fall, 2013, Vol. 31, Issue 2, pp. 9-19.

BARBEITA, Magda (2013), Uma imagem é uma imagem é uma imagem: as narrativas de demanda de Francisco José Viegas, Dissertação de Mestrado, Porto, Univ. do Porto. In https:|/repositorio-aberto.up.pt/handle/10216/72302

BERTONERI, Gaia (2015), «Histórias Policiais di Ana Teresa Pereira: proiezioni per uno spettatore attento», in Hora fecunda. Scritti in onore di Giancarlo Depretis, a cura di Paola Calef, Francisco Estévez, António Fournier, Torino, Nuova Trauben, pp. 573-583. Disponível em academia.edu. https://www.academia.edu/31862855

BRIONES, Ana Isabel (1998), «Género e Contragénero. Tópicos do romance policial na narrativa portuguesa dos anos oitenta como via de reflexão histórica», in Revista de Filologia Românica, n.․15, pp. 267-280.

CASTRO, Paul Melo e (2011), «Five Cases From 130 Years of Portuguese Detective Fiction, 1870s-2000s», in Iberian Crime Fiction, Cardiff, University of Wales Press, Vosberg, N., pp. 116-144.

COELHO, Eduardo Prado (2001), «Aquele que fala com os mortos», Publico, 27 Out. 2001, in https://www.publico.pt/2001/10/27/jornal/aquele-que-fala-com-os-mortos-163459

CUNHA, Mafalda Ferin (2002), «A tentação do policial no romance português contemporâneo», in Revista Colóquio/Letras, n.ํㅜ161/162, Jul. 2002, pp. 275-294.

DUSLEAG, Elisabeth (2011), Gesellschaftskritik in portugiesischen Kriminaltexten. Clara Pinto Correia Adeus, Princesa als Anti-detektivroman «Verfasserin, angestrebter akademischer GradMagistra der Philosophie (Mag.phil.) Romanistik Portugiesisch, Universität Wien. In https://core.ac.uk/download/pdf/11595624.pdf

ERDMANN, Eva (2009), «Nationality International: Detective Fiction in the late Twentieth Century», in Investigating Identities. Questions of Identity in Contemporary International Crime Fiction, ed. by Marieke Krajenbrink and Kate M. Quinn, Amsterdan/New York, Rodopi, pp. 11-26.

FEIJÓ, José Elias Torres (1995), «Litoral. ‘Ara Solis’ de Wanda Ramos: Um regresso às raízes, in Actas do 4. . Congresso da Associação Internacional de Lusitanistas, Lisboa-Porto-Coimbra: Universidade de Hamburgo/Lidel, pp. 447-458. Disponível em http://www.academia.edu/4124518/

FRANÇOIS, Marion (2006), «Le lecteur, pièce maitresse de l'appareil policier», in Cahiers 
ican Association of Teachers of Spanish and Portuguese, Durham, University of New Hampshire, SS. 59-68.

MENDONÇA, Mariana Cepeda (2017), Fogo-fátuo? Mulheres detetives na ficção policial brasileira, Dissertação de Mestrado, Porto, Univ. do Porto, in https:|/repositorio-berto.up.pt/ bitstream/10216/109345/2/235023.pdf

MESSENT, Peter (ed.) (1997), Criminal Proceedings: The Contemporary american Crime Novel, London and Chicago, Pluto Press.

PINHEIRO, Duarte (2011), Além Sombras: Ana Teresa Pereira, Porto, Fonte da Palavra. (2011) «TRILHOS DE UMA IDENTIDADE ITALIANA NO ROMANCE POLICIAL PORTUGUÊS CONTEMPORÂNEO«, Universidade de Salerno, in Anuário de Literatura, ISSNe: 2175-7917, vol. 16, n. 2, p. 128-144. file://C:/Users/MLS/Downloads/20070-70216-1-PB.pdf

PLAIN, Gil (2001), Twentieth-Century Crime Fiction. Gender. Sexuality and the Body, Edinburgh, Edinburgh University Press.

PRANVILLE, Pierre-Michel (2009), Sept romans policiers portugais révélés au bain de l'Histoire, enquêtes policières et quête d'identité: La littérature policière de Modesto Navarro (1982-2002), Paris, Université Paris 3 - Sorbonne Nouvelle (Mémoire de Master 2. Littérature Portugaise).

QUIROGA, Carlos (1999), «Agustina no Policial», in Agustina (1948-1998). Bodas escritas de oiro, Porto, Univ. Fernando Pessoa, pp. 89-101.

SAMPAIO, Maria de Lurdes Morgado (2007), História Crítica do Género Policial em Portugal (1870-1970): Transfusões e Transferências, vol. 1 e vol. 2 (Anexos) (tese de doutoramento), Porto, Faculdade de Letras da Univ. do Porto.

(2009), «Millenium Trilogy: an eye for an eye and the utopia of order in modern waste lands», CROSS-CULTURAL COMMUNICATION, Vol. 7, n.․․ 2, pp. 73-81.

SARAIVA, Arnaldo (1973), «Inquérito sobre Literatura Maior e Literatura Menor» (1961), in Encontros Des Encontros, Porto, Livraria Paisagem, pp. 8391 [Publicado anteriormente em Rumo, n. ํ 58, Dez. 1961].

SARDO, Anabela (2013), A Audácia de ser Diferente: a Escrita Obsessiva de Ana Teresa Pereira. Tese de Doutoramento, Aveiro, Universidade de Aveiro. (2014), «A Propósito do texto ‘Os Insuspeitos’, As paixões de Ana Teresa Pereira», in Atas/anais do XXI COLÓQUIO DA LUSOFONIA, S. Miguel-Açores, pp. 75-86. In http:// bdigital.ipg.pt/dspace/bitstream/10314/2399/1/Ata\%20Cientifica_anabelasardo.pdf SPANOS, William (1972), «The Detective and the Boundary: some Notes on The Post-Modern Literary Imagination», in Boundary, 2, 1, Fall, pp. 147-168.

SWANSON, Philip (2009), «The Detective and the Disappeared: Memory, Forgetting and Other Confusions in Juan José Saer's La Pesquisa», in Investigating Identities. Questions of Identity in Contemporary International Crime Fiction, pp. 277-294.

VASCONCELOS, Helena (1996), «Delito sem Corpo, de Ana Nobre de Gusmão», Entrevista à autora, in Leituras \& Sons, Público, 2 Março, p. 8. 
II. Outros quadrantes europeus 



\section{A narrativa criminal escrita por mulheres em Espanha (1975-2018)*}

Elena Losada Soler

Universidad de Barcelona

\section{1. $O$ «boom» da ficção criminal em Espanha ${ }^{1}$}

O começo do novo milénio em Espanha foi marcado literariamente pela eclosão de um «boom» sem precedentes da ficção criminal, um auge que transformou um género literário (subgénero?) tradicionalmente associado à cultura popular numa ferramenta de interpretação da realidade social, que tem acompanhado o impacto da crise económica dos últimos anos ao ponto de poder ser chamada a «ficção da crise».

Por volta de 2005 o lugar de honra das montras de best sellers das livrarias, até então ocupado pela ficção histórica, passou a ser dominado por um outro género literário, a literatura criminal, fundamentalmente romances. Narrativa norte-americana e inglesa, como de costume, também os novos nomes franceses, mas, sobretudo, ficção escandinava: Henning Mankell, Stieg Larsson e o islandês Arnaldur Indridason, entre outros, abriram o caminho para um desfile interminável de autores nórdicos. A análise dos fatores deste sucesso e a sua possível influência na ficção criminal espanhola não foi ainda completada, mas é absolutamente imprescindível.

A estes crimes vindos do Norte juntaram-se rapidamente outros autores culturalmente mais próximos, como o italiano Andrea Camilleri, cujo comissário Montalbano é uma homenagem ao escritor Manuel Vázquez Montalbán, ou

\footnotetext{
* Este texto faz parte dos resultados do projeto «Víctimas y agresoras. Representaciones de la violencia en la narrativa criminal escrita por mujeres (VANACEM).) FEM 2014-55057» e do Grup de Recerca Consolidat «GRC-Creació i pensament de les dones (2014 SGR 44)».

${ }^{1}$ Usamos o termo «criminal» em lugar do mais habitual «policial» por ser mais abrangente. Nem todos estes textos são de procedimento policial ou têm um polícia como protagonista, todos eles porém narram um crime e a sua investigação.
} 
Petros Markaris, excepcional cronista da crise grega dos últimos anos. O menosprezado subgénero transformou-se numa forma de narrativa em torno da qual se articulou uma parte importante da literatura popular. A «fórmula criminal» tornou-se fronteiriça com outros géneros: romance de terror, em alguns excelentes textos de Fred Vargas, por exemplo; romance urbano na narrativa brasileira de Patrícia Melo e Ana Paula Maia, romance histórico com os detetives vitorianos de Anne Perry ou a soror Fidelma medieval de Peter Tremayne, etc. Este grande sucesso comercial e crítico foi acompanhado quase de imediato pela emergência de uma nova geração de narradores espanhóis a praticarem um género já «dignificado» e em condições socioculturais bem diferentes das que tiveram os seus predecessores dos anos 70 e 80.

\section{Os inícios da ficção criminal em Espanha e um mistério: onde estão as autoras?}

É importante salientar que não se pode falar realmente em ficção criminal em Espanha até à morte de Franco (1975). Trata-se de um fenómeno diretamente ligado à Transición e ao fim da censura. Teria sido impensável, inaceitável pelo regime franquista, uma narrativa da realidade parecida com a do noir norte-americano. Na Espanha arcaica da ditadura militar-católica, não podia existir essa fratura da ordem, essa desobediência, que é sempre um crime. Também não seria possível imaginar uma figura literária positiva e verosímil de polícia como a que representou em França o comissário Maigret, de Simenon. Durante os quarenta anos da ditadura, a literatura criminal foi apenas um subgénero de romance popular, escrito de maneira industrial e publicado em coleções de capas coloridas e papel barato por autores sob pseudónimos anglo-saxónicos e com histórias ambientadas em espaços de "perdição», alheios, e por isso aceitáveis, como as grandes cidades norte-americanas. E entre esses «operários» da ficção criminal houve também mulheres, como María Fernanda Cano Caparrós, que, nos anos 60, publicava romances sob o nome, muito adequado, de Mary Francis Colt.

Exceções a esta situação foram o romance El inocente (1953), de Mario Lacruz, e muito especialmente, os romances de Francisco García Pavón, nos anos 60, de ambientação rural (Tomelloso, La Mancha) e com um investigador-filósofo, Manuel González «Plinio», como protagonista, nos antípodas de Philip Marlowe. Os romances tratavam de crimes rurais, pré-modernos e também arcaicos, que a cen- 
sura tolerou. Será preciso esperar até 1975 e pela construção de uma outra Espanha para encontrar realmente literatura criminal, como frisa José E. Colmeiro:

La aparición de la novela policíaca negra en España coincide esencialmente con estos años de transición en el sentido más amplio (transición al régimen democrático, a la economía posindustrial, a la recuperación de las autonomías, a la incorporación a la Europa comunitaria) y de crisis social (problemas del desempleo, de la droga, del aumento de la criminalidad y la inseguridad ciudadana). (Colmeiro 1994: 222)

Neste primeiro surto da ficção criminal moderna, muito marcada pelo noir e fortemente social, não faltaram nomes de mulher. Como de costume, porém, ficaram num segundo plano ou foram diretamente invisibilizadas. $O$ facto de ver como, quarenta anos depois, no auge do «boom» se repetia a desatenção às autoras, levou-nos a iniciar uma linha de pesquisa, através de dois projetos do Ministerio de Educación, ${ }^{2}$ para catalogar e analisar a partir de uma perspetiva de género (gender) esse corpus literário, que parecia ser mínimo. Oito anos depois, a nossa base de dados, www.ub.edu/munce recolhe mais de 70 autoras e 170 títulos. A autoria feminina na ficção criminal já não pode ser considerada marginal. E neste auge atual do género encontramos muitos nomes de mulher, como já acontecera na literatura britânica e americana, onde Sue Grafton ou Sara Paretsky, herdeiras de Patricia Highsmith, são figuras consagradas. Obviamente, as escritoras de narrativa criminal espanhola não constituem um bloco homogéneo, não escrevem todas a partir de um prisma feminista; o arco ideológico delas, entre a esquerda radical e militantemente feminista de Cristina Fallarás e o catolicismo próximo da Opus Dei de Reyes Calderón, é absolutamente díspar, também não usam a mesma estética literária, nem têm a mesma qualidade, mas entre todas constroem um tecido de texturas diversas.

\section{As mulheres reencontradas}

Quando em 1979 Lourdes Ortiz publicou Picadura mortal iniciou (embora esse fosse o seu único romance neste género) o caminho do romance criminal

\footnotetext{
${ }^{2}$ «Mujeres y novela criminal en España (1975-2010): autoras, figuras de poder, víctimas y criminales». (MUNCE), FEM2011-22870, 01/01/2012-31/12/2014 e «Víctimas y agresoras. Representaciones de la violencia en la narrativa criminal escrita por mujeres». (VANACEM) FEM2014-55057-p, 01/01/2015$31 / 12 / 2018$.
} 
De hecho, pese a mi brillante formación como abogada y mis estudios policiales en la Academia, nunca se me habían encargado casos de relumbrón. Estaba considerada «una intelectual», además era mujer y sólo me faltaba la etnia negra o gitana para completar el cuadro de marginalidad. (Giménez-Bartlett 2010: 11)

Petra Delicado, os seus conflitos com o comissário-chefe e a sua relação com o seu subalterno Fermín Garzón, homem mais velho e tradicional, que evolui de um desconforto mútuo a uma sincera amizade, marcará de maneira incontornável futuras protagonistas de outras autoras. Petra, porém, é uma personagem de uma certa ambiguidade, como apontou Shelley Godsland:

Inspector Petra Delicado - like other Spanish women - exists within a post-feminist economy, and that this siting proves eminently problematic because many concerns of earlier feminist movements have not been resolved even though post-feminism has evolved as the contemporary modus operandi and modus vivendi, so to speak. Petra is undoubtedly an ambiguous figure. A woman who appears to enjoy social, sexual, financial, and some professional autonomy, but whose positioning within the police force and whose own perspective on many gender issues appear to render many of those autonomies of questionable authenticity. (Godsland 2007: 40)

Ao contrário do feminismo à Simone de Beauvoir de Lònia Guiu, a detetive dos romances de Maria Antónia Oliver, enraizada no pensamento do movimento feminista espanhol dos anos 70, Petra Delicado aponta, como pioneira, traços dos pós-feminismos que apareceram em Espanha nos anos 90. Lónia Guiu é detetive e não polícia, porque, na esteira do «feminismo da diferença» italiano dos anos 80, não quer participar do mal intrínseco de uma organização patriarcal como o corpo de polícia, não usa armas e explicita nas tramas que investiga (habitualmente ataques contra mulheres) e na sua linguagem esse feminismo. Petra, pelo contrário, é inequivocamente polícia, escolhe ser polícia e participa, embora com essas contradições que Godsland aponta, do "mal do amo». Assim foi como Amelia Valcárcel, um dos grandes nomes do «feminismo da paridade», definiu, provocadoramente, a estrutura patriarcal:

De esta forma sólo queda una vía abierta al par universalidad-igualdad: que las mujeres hagan suyo el actual código de los varones, por cierto, casi completamente señalable en la cuestión de los contenidos. universalicemos definitivamente, contribuyamos al bien haciendo el mal. si no los podemos hacer tan buenos, hagámo- 
nos nosotras tan malas (...) pero no a cualquier mal, no desde la perspectiva de aquel pequeño mal que se te reconoce (...) realiza por el contrario el verdadero mal, el mal del amo. (...) no reclamamos entonces nuestro mal, el mal por el que se nos ha definido y no queremos tampoco el bien que se nos imputa, sino exactamente vuestro mal. este es un discurso moral feminista verdaderamente universal en el que no se pretende mostrar la excelencia, sino reclamar el derecho a no ser excelente. Como vuestro logos moral desde siempre ha funcionado. (Valcárcel 1994: 164-165)

Este é um problema que recorre, de maneira consciente ou inconsciente, em grande parte da ficção criminal escrita por mulheres, especialmente no caso daquelas autoras mais diretamente ligadas ao pensamento feminista. A questão é de uma falsa simplicidade: uma mulher polícia, militar, juiz, é uma mulher empoderada ou uma mulher que participa de um mal estrutural, o patriarcado? A representação simbólica deste dilema é a pistola, e a legitimidade da utilização ou não desse símbolo fálico. Embora estas personagens investigadoras, que, é preciso salientá-lo, precisam de justificar muito mais do que os seus colegas masculinos as causas pelas quais decidiram integrar-se nos corpos de segurança do Estado, começam por ter alguma relutância no uso da arma, todas acabam por se habituar a ela, por integrá-la no seu trabalho e na sua vida diária, quer a usem, quer não. Shelley Gosdsland mostra a progressiva adaptação de Petra Delicado à pistola:

Petra is unable to use her gun because she has left the weapon in her bag in their police car. By the most recent novel, however, she has become used to carrying her fire arm with her at all times, and it makes many - and brutal- appearances within Un barco cargado de arroz. (Godsland 2007: 55)

Trata-se de uma representação simbólica da adoção por parte da mulher da violência masculina ou, pelo contrário, de um progressivo empoderamento? A questão fica em aberto.

\section{O século XXI}

Já no século XXI a cartografia da ficção criminal escrita por mulheres alargou-se até se tornar quase incontrolável. Dada a impossibilidade, e a inutili- 
dade, de fazer uma lista exaustiva de nomes e de obras, ${ }^{7}$ limitar-me-ei àquelas que têm tido um eco maior, de público ou de crítica, e que têm uma produção consolidada.

Dada a diversidade cultural e linguística de Espanha é importante lembrar e salientar que cada uma dessas línguas e culturas tem produzido o seu corpus de ficção criminal de maneira e em quantidade proporcional e coerente com as respectivas situações sociolinguísticas e a composição do seu público potencial, facto que afeta substancialmente o número e a penetração social desses textos. Obviamente, a maior parte do corpus está em espanhol, embora a ficção criminal catalã tenha sido pioneira, muito importante e com um grande sucesso popular. A produção galega e basca é muito mais reduzida, embora também mostre uma tendência timidamente ascendente.

Do ponto de vista da qualidade literária e também da consolidação da sua carreira, posso salientar entre as escritoras em espanhol, embora consciente de que outros nomes relevantes ficam de fora, os nomes de Berna González Harbour, Marta Sanz, Rosa Ribas, Cristina Fallarás e Empar Fernández.

Em 2012, Berna González Harbour (n. 1965), jornalista de profissão, ${ }^{8}$ deu início ao seu percurso literário com Verano en rojo, um romance que seria a estreia da sua protagonista, a comissária María Ruiz, uma das figuras de mulher polícia mais interessantes do panorama atual. Este seria o primeiro volume de uma série que conta hoje com três títulos: o mencionado Verano en rojo, Margen de error (2014) e Las lágrimas de Claire Jones (2017). Nestes três romances, González Harbour desenvolveu um painel de temas relevantes na sociedade espanhola de começos do século XXI: a pedofilia no seio da Igreja Católica, a máfia empresarial em tempos de crise e a corrupção policial.

Marta Sanz (n.1967), filóloga, ensaísta e professora, tem uma das escritas mais cuidadas e elaboradas do catálogo de escritoras espanholas contemporâneas, uma escrita perpassada por uma vontade de literariedade que é um verdadeiro programa estético e ético. Na sua já vasta obra encontramos apenas dois

\footnotetext{
${ }^{7}$ Mesmo consciente disso não posso deixar de mencionar algumas destas escritoras, para além das que serão depois referidas com mais pormenor: Susana Hernández, Mercedes Castro, Maruja Torres, Graziella Moreno, Susana Martín Gijón, Adelaida García Morales, Susana Rodríguez Lezaun, María Oruña, Esperança Camps, Elena Torres Girbau, Isabel Franc, Anna Grau, Montse Sanjuan, Laura Peñalver ou Ángela Vallvey.

${ }^{8}$ Referirei a data de nascimento e a profissão inicial destas autoras por serem dados significativos que permitem enquadrá-las numa geração e numa formação prévia. O olhar delas sobre o mundo e a sua maneira de confrontar a tarefa literária tem muito a ver com esse ponto de partida.
} 
romances criminais: Black, black, black (2010) e Un buen detective no se casa jamás (2012), ambos cheios de narrativa inteligente e formalmente ricos e originais. Embora o protagonista - o peculiar Arturo Zarco - seja masculino, estes romances constituem um verdadeiro repertório de personagens femininas a lutarem contra a sociedade e as suas visíveis e invisíveis violências.

Depois da sua defesa de tese de doutoramento em Filologia, Rosa Ribas (n. 1963) foi viver para a Alemanha. A partir de Frankfurt construiu uma série de quatro romances (Entre dos aguas, 2007, Con anuncio, 2009, En caída libre, 2011 e Si no, lo matamos, 2016) protagonizados pela «komissärin» Cornelia Weber-Tejedor, filha de uma emigrante espanhola e de um operário alemão. A duplicação do significado do nome (ambos significam «tecedor») e a construção desta personagem bicultural, bilingue, e mulher num contexto adverso como é a Brigada de Homicídios, permite ao leitor ir além do entretenimento da intriga, que é muito, e refletir sobre diversas formas de discriminação e de marginalização. Paralelamente, tem publicado, em colaboração com Sabine Hofmann, uma trilogia protagonizada pela jornalista Ana Martí e ambientada na Barcelona dos anos 50: Don de lenguas, 2013; El gran frío, 2014 e Azul marino, 2016. Os três romances constituem um fresco histórico-social do franquismo que ultrapassa em muito o conceito de «subgénero» narrativo habitualmente atribuído à ficção criminal.

Cristina Fallarás (n. 1968), jornalista, é a voz mais radical desta lista. Militantemente feminista mesmo antes do ressurgir atual do movimento, a sua escrita, fortemente emocional, potente e elaborada, tem a sua máxima expressão no romance Las niñas perdidas (2011), de cuja leitura não se sai indemne. O romance narra uma trama selvagem, que toca todos aqueles temas proibidos pelo politically correct. O tom da escrita é um constante grito, uma interpelação violenta ao leitor, e esta raiva serve para desenvolver, com uma perspetiva insólita, um dos temas recorrentes na ficção criminal de autoria feminina: a maternidade. Uma grávida atípica, a detetive protagonista, deverá investigar o assassinato de duas meninas que a instituição que deveria proteger a infância retirou da custódia de uma mãe «oficialmente» incapaz. O que é ser uma mãe capaz? Qual o acrescido risco para uma menina numa sociedade que se tornou brutal? São talvez perguntas sem resposta.

Empar Fernández (n. 1962), professora, começou o seu caminho na ficção criminal com uma trilogia escrita em colaboração com Pablo Borrell Goytisolo e um protagonista masculino, o comissário Santiago Escalona. Nos últimos anos, já a sós, publicou três romances (Sin causa aparente, 2011; La mujer que no bajo del 
avión 2014; La última llamada, 2015) que constituem a crónica mais precisa que a literatura, criminal ou não, tem feito sobre os efeitos da crise económica na sociedade. Romances do quotidiano, do aparentemente simples, às vezes ficção criminal quase sem crime, como em La mujer que no bajo del avión. A sua escrita severa e realista, que alguns críticos consideram nos limites do noir com o romance urbano, tem gerado uma nova «etiqueta» muito interessante para a classificação da moderna ficção criminal: já não é noir, é «cinzento-asfalto».

No que diz respeito à literatura criminal em catalão, a segunda em termos de produção, é preciso salientar o caso de Carme Riera (n.1948), autora canónica, académica da Real Academia de la Lengua, que, já com uma longa bagagem como romancista, decidiu em 2011 iniciar-se no género com Natura quase morta, um romance inspirado num facto real que combina o criminal com outro subgénero narrativo muito pouco frequentado em Espanha: o romance de campus. Por outro lado, Carolina Solé (n. 1966), com os seus romances Ulls de gel (2013) e El vincle perfecte (2016) provou que a ficção criminal, fora dos limites do noir, é viável num espaço rural.

Outras autoras encontraram também um espaço e sucesso no público e na crítica. Entre elas Margarida Aritzeta e Teresa Solana. Margarida Aritzeta (n.1953), professora de universidade, participou em 1983 num interessante projeto de escrita coletiva: Ofélia Dracs, uma imaginária autora, que era o nome de guerra comum de um coletivo de mais de quinze autores que se propuseram escrever em catalão, naquela altura uma língua fragilizada por quarenta anos de ditadura e carente de um corpus significativo de literatura popular, ${ }^{9}$ um corpus novo de literatura de "género», ou seja, erótica, de mistério, criminal, de terror, de ficção científica etc., que ocultava a identidade dos seus autores, «em conluio» nesse projeto literário-cultural, sob esse peculiar pseudónimo. Depois de alguns anos mais virada para a literatura infanto-juvenil, Aritzeta voltou ao género criminal para adultos com uma série protagonizada pela inspetora da polícia autónoma catalã, Mina Fuster (L'amant xinés, 2015; Els fils de l'aranya, 2016 e Rapsòdia per a um mort, 2018), uma mulher ao mesmo tempo dura e vulnerável às suas próprias contradições e vítima de uma mãe, que Pierre Lacan descre-

\footnotetext{
${ }^{9}$ As literaturas minoritárias e com percursos políticos complexos costumam apresentar esta situação. A necessidade de se manter como literatura canónica faz com que todos os esforços se concentrem na criação de «alta literatura». Talvez por isso, a literatura catalã, e ainda mais a galega e a basca, tiveram dificuldades em construir esse corpus de «subgéneros», que as literaturas centrais já tinham no século XIX.
} 
veria como «devastadora». Teresa Solana (n.1962), filósofa e tradutora, tem desenvolvido desde 2006 uma das carreiras mais regulares da ficção criminal escrita por mulheres, com seis romances e dois livros de contos. Os romances agrupam-se em duas séries. A primeira, protagonizada pelos intencionadamente inverosímeis detetives gémeos, Eduard e Borja («Pep») ${ }^{10}$ Martínez, apresenta tramas cómicas, quase paródicas, muito ligadas à realidade social e cultural de Barcelona, num tom que, às vezes, faz lembrar a tradição picaresca. Conta até ao momento com quatro quatro romances: Un crim imperfecte, 2006; Drecera al Paradís, 2007; L' hora zen, 2011 e Campanades de boda, 2016. A outra série, de tom mais grave e realista, é protagonizada pela subinspectora dos Mossos d'Esquadra (policía catalã) Norma Forester e tem até agora dois títulos: Negres tempestes, 2010 e La casa de les papallones, 2014. O nome da protagonista é significativo: o apelido inglês Forester (que escrito «Foraster» tem o mesmo significado em catalão) era o do bisavô dela, um anarquista idealista que fez parte das Brigadas Internacionais e foi fuzilado pelos franquistas. O nome Norma deve-o ao lado feminino da família, quatro gerações de mulheres da alta burguesia catalã que tem como característica a escolha de nomes de heroínas de ópera: ${ }^{11}$ Senta, Mimí, Norma e Violeta. Tramas realistas, ligadas a problemas atuais, como os conflitos com a memória histórica mal resolvida do franquismo ou o movimento «okupa», caracterizam estes romances.

O panorama basco apresenta características especiais, particularmente no que diz respeito à língua e à difusão destes romances. No contexto espanhol, consideramos literatura catalã, embora não seja uma questão pacífica, unicamente a produção escrita nesta língua. No caso basco, porém, dadas as condições sociolinguísticas ${ }^{12}$ da comunidade, o conceito é mais abrangente e inclui, também de maneira discutida e discutível, a obra de autores bascos em espanhol. Habitualmente estas obras, independentemente da língua em que foram escritas, são traduzidas para a outra língua e convivem nas livrarias nas duas versões. Uma exceção interessante é o caso de Itxaro Borda (n. 1959), autora em língua basca

\footnotetext{
${ }^{10}$ «Borja» (Francisco de Borja) é um nome vinculado no imaginário espanhol à classe alta ou a uma classe média que a tenta imitar. Habitualmente é usado para gags cómicos caracterizando personagens que tentam parecer o que não são. Ressalvando grandes distâncias, o equivalente em português poderia ser o par Bernardo e Zeca. Pep, ao contrário é o diminutivo catalão, popular e rural, para José. As contradições deste «Pep» que tenta ser um «Borja» resultam de uma comicidade muito eficaz. ${ }^{11}$ Um piscar de olhos à tradição operística da burguesia catalã.

${ }^{12}$ Ao contrário do que acontece na Catalunha, uma parte da população basca não fala nem lê em basco.
} 
mas nascida no País Basco francês (Iparralde, em basco) e de nacionalidade francesa, cuja pioneira obra de ficção criminal $^{13}$ não foi traduzida nem para francês nem para espanhol. Itxaro Borda criou uma personagem - Amaia Ezpeldoi que é uma detetive rural, lésbica e queer (Lasarte 2015: 147), capaz de investigar com o mesmo interesse uma morte misteriosa, um crime ecológico ou o roubo de uma vaca. Como assinala Gema Lasarte, os romances de Borda apresentam «(...) un retrato de los conflitos más importantes de la sociedad vasca (la situación política, del país, el euskera, la insumisión, la industrialización)»(Lasarte 2015: 148).

Itxaro Borda abriu o caminho para novos nomes de ficção criminal, hoje já em número relevante, autoras de romances ambientados no País Basco em qualquer das duas línguas, e entre as que destacam Amaia Manzisidor e Elena Fernández. Amaia Manzisidor (n. 1957), engenheira técnica mecânica e professora, é autora de dois romances (Bilbao Expediente 406, 2014 e Urdaibai Sangriento, 2017) protagonizados pela dupla mais habitual da ficção criminal escrita por mulheres, uma figura investigadora feminina com um alto cargo e um subalterno masculino, neste caso a comissária Julieta Laborda e o seu ajudante Pepe Dueñas. Elena Fernández (n. 1965) é autora de Cerezas amargas (2016), um romance fronteiriço com a ficção histórica e com duas tramas paralelas, uma a decorrer no tempo atual e outra no século XVIII, ambas com a violência de género como traço comum.

Nos últimos anos, dois dos nomes mais relevantes do género, pelo seu sucesso popular e número de vendas em toda Espanha, são as autoras bascas Dolores Redondo e Eva García Sáenz de Urturi.

Dolores Redondo (n. 1969), chefe de cozinha com estudos de Direito, é autora do grande best seller dos últimos anos: a Trilogía del Baztán ${ }^{14}$, formada por El guardián invisible. 2012:15 Legado en los huesos, 2013 e Ofrenda a la tormenta, 2014. Remotamente baseada num truculento sucesso real e nos limites do género de terror, a trilogia protagonizada pela inspetora Amaia Salazar, da polícia foral de Navarra, em luta interna com a sua terrível mãe-ogro, usa de maneira muito efetiva os

\footnotetext{
${ }^{13} \mathrm{Um}$ conjunto de cinco romances não traduzido, pelo facto de que Borda não usa o euskera comum, mas o seu dialeto, o sulentino. Os títulos são: Bakean ützi arte (Hasta que nos dejen em paz, 194, Bizi nizano munduan (Mientras viva, 1996), Amorezko pena baño (Más que uma pena de amor, 1996), Jagi hadi plazara (Sal al exterior, 2007) e Boga-boga (2012).

${ }^{14}$ O Baztán é um belíssimo vale no norte de Navarra, zona vasco falante, fronteiriça com o País Basco.

${ }^{15} \mathrm{O}$ sucesso deste romance propiciou uma adaptação cinematográfica com o mesmo título, dirigida por Fernando González Molina e estreada em 2011.
} 
cioso romance, nos últimos anos cabe acrescentar o trabalho de mais duas autoras: María Acosta Díaz (n.1959), jornalista e professora, autora de dois romances juvenis de mistério: 0 enigma dos nove sepulcros e Patacas e máis patacas: 0 misterio da Casa Grande e Sabela Muñiz (n.1993), autora de A porta da Europa (2013), um romance que trata o problema do narcotráfico das Rías Baixas, que marcou a sociedade galega nos anos 80 e 90 e que conta já com abundante tratamento ficcional.

\section{Conclusões}

Como vemos, pois, a ficção criminal de autoria feminina em Espanha não é um fenómeno marginal nem estranho. Insere-se em boa proporção e de maneira natural no «boom» dos últimos anos e apresenta aos leitores uma cartografia relevante das mudanças sociais nos estereótipos de género e das variações ocorridas nos últimos anos nas relações entre mulher e poder. Uma evolução visível na linguagem das personagens, que varia entre a reprodução desses estereótipos e a subversão. Estes romances, em resumo, oferecem representações de figuras de poder femininas, mulheres empoderadas e com agência. Estas novas investigadoras participam da estrutura do poder patriarcal, e, ao criar estas figuras femininas, dotadas do "poder do amo» e da sua simbologia - a lei e a pistola as autoras criaram também novas masculinidades, vindo alterar assim, profundamente, as convenções da literatura criminal como género literário e também os estereótipos do género sexual.

Da mão destas autoras, e, para além dessas representações de mulheres fortes e de homens em transição de modelo, apareceram também novas maneiras de representar crimes sociais como os maus-tratos ou o tráfico de mulheres (El hombre del corazón negro, de Ángela Vallvey, por exemplo). Encontramos diferenças também na representação de novas figuras femininas de criminal, que nestes romances matam às vezes ${ }^{16}$ por motivos (ou de maneiras) não ligadas à imagem tradicional do crime feminino, com veneno, ou induzindo um homem

\footnotetext{
${ }^{16}$ Embora seja relevante a aparição destas novas representações da mulher criminal é preciso frisar que é extremamente minoritário. Neste aspeto, a tradição é tenaz e, mesmo quando se trata de um romance de autoria feminina, as mulheres criminosas continuam presas do convencionalismo: matam por ciúmes, para herdar o dinheiro de um familiar, para proteger os filhos. Crimes, enfim, do âmbito doméstico. O mundo de Héstia, deusa do lar, que foi durante séculos o mundo das mulheres, ainda tem muito peso.
} 
a cometer o crime dela. E talvez seja esta reflexão sobre a violência e o mal das mulheres, feita fora dos parâmetros da tradição patriarcal, um dos elementos mais perturbadores destes textos.

Novos temas, novas personagens, nova linguagem (embora algumas autoras continuem fiéis aos estereótipos) para narrar de um ponto de vista diferente, e com grande sucesso de público e de crítica, os eternos crimes e a patética humana.

\section{Bibliografia}

BUTLER, Judith (2006), Vida precária, Buenos Aires, Paidós [2004].

CAVARERO, Adriana (2009), Horrorismo. nombrando la violencia contemporánea, Barcelona, Anthropos Editorialetropolitana [2007].

COLMEIRO, José F. (1994), La novela policiaca española. Teoría e historia crítica, Barcelona, Anthropos.

GIMÉNEZ BARTLETT, Alicia (2010), Ritos de muer, Barcelona, Planeta (Booket) [1996].

GODSLAND, Shelley (2007), Killing Carmens. Women's Crime fiction from Spain, Cardiff, University of Wales Press.

LAMA, María Jesús (2015), "La parodia de la figura tradicional del detective en la novela negra de Laura Caveiro», in Losada, Elena e Paszkiewicz, Katarzyna (eds.), Tras la pista. Narrativa criminal escrita por mujeres, Barcelona, Icaria (Mujeres y Culturas), pp. 161-182.

LASARTE, Gema (2015), «La novela criminal vasca y el lesbianismo: Amaia Ezpeldoi, detective queer», in Losada, Elena e Paszkiewicz, Katarzynba (eds.), Tras la pista. Narrativa criminal escrita por mujeres, Barcelona, Icaria (Mujeres y Culturas), pp. 147-160.

PASZKIEWICZ, Katarzyna (2015), «Autoridad especular, autoridad lingüística: Petra Delicado en la pantalla televisiva», in Losada, Elena e Paszkiewicz, Katarzyna (eds.), Tras la pista. Narrativa criminal escrita por mujeres, Barcelona, Icaria (Mujeres y Culturas), pp. 219-240.

VALCÁRCELL, Amelia (1994), Sexo y filosofía. Sobre «mujer» $y$ «poder», Barcelon, Editorial Anthropos. 


\section{Herland, a rede de autoras feministas de romances de detectives em língua alemã}

Kirsten Reimers

Univ. Hamburgo

Logo entre os primeiros autores de literatura policial se encontram não apenas escritoras no espaço anglo-americano mas também no de expressão alemã. Exemplos precoces são Auguste Groner, autora de novelas e romances policiais em fins do séc. XIX; ${ }^{1}$ Gabriele von Schlippenbach, cuja produção escrita data da mesma época ${ }^{2}$ ou ainda Hermynia zur Mühlen ${ }^{3}$ que, a partir dos anos 20 do século passado, também escreveu, entre outras coisas, romances policiais. Groner, em particular, tal como von Schlippenbach, recorreram geralmente a um pseudónimo masculino.

Na Alemanha, é a partir de 1980 que surgem romances policiais explicitamente feministas, predominando, de início, as traduções do inglês. ${ }^{4}$ Nestes romances apareciam, pela primeira vez, no centro da acção, detectives profissionais do sexo feminino que actuavam de forma tão segura de si e competente como os seus contrapontos masculinos. Entre as primeiras autoras traduzidas contam-se, por exemplo, a britânica Liza Cody, na realidade Liza Nassim, tal como a norte-americana Sara Paretsky que foi igualmente co-fundadora da rede femi-

\footnotetext{
${ }^{1}$ Ver, por ex., Armin Arnold/Josef Schmidt (1978), Reclams Kriminalromanführer, Stuttgart, Reclam, p. 182.

${ }^{2}$ Ver, por ex., ibidem, p. 306.

${ }^{3}$ Ver, por ex., a biografia e a bibliografia da autora no projecto «Transdisziplinäre Konstellationen in der österreichischen Literatur, Kunst und Kultur der Zwischenkriegszeit», coordenado por Primus-Heinz Kucher da Universidade de Klagenfurt; online em https://itkult1920er.aau.at/litkult-lexikon/zur-muehlen-hermynia/; último acesso a 30.04.2019.

${ }^{4}$ Em relação ao romance policial feminista no espaço anglo-americano ver, por ex., Maureen T. Reddy (1988), Sisters in Crime: Feminism and the Crime Novel, Londres/Nova Iorque, Continuum; Gabriele Dietze (1997), Hardboiled Women. Geschlechterkrieg im amerikanischen Kriminalroman, Hamburgo, Europäische Verlagsanstalt. Em relação ao "policial de mulheres», ou seja, romance policial feminista de expressão alemã ver, por ex., Nicola Barfoot (2007), Frauenkrimi/polar féminin. Generic Expectations an die Reception of Recent French and German Crime Novels by Women, Frankfurt/Main, Peter Lang.
} 
nista de romancistas policiais «Sisters in Crime». O primeiro romance policial de Cody, Dupe, surgiu, em versão original, em 1980, sendo a tradução alemã publicada em 1986 com o título Video-Piraten. ${ }^{5}$ Indemnity Only, o primeiro romance policial de Paretsky, apareceu em versão original em 1982 e, em versão alemã, em 1986, com o título Schadenersatz. ${ }^{6}$ Estes romances policiais tiveram grande sucesso no espaço de expressão alemã. Numa fase seguinte, as autoras de língua alemã começaram também a dar protagonismo a personagens do sexo feminino com consciência do seu valor. Entre as primeiras autoras feministas de romances policiais encontram-se, por exemplo, Pieke Biermann e Doris Gercke. O primeiro romance policial de Biermann, Potsdamer Ableben [Morte em Potsdam] surgiu em 1987; ${ }^{7}$ a estreia de Gercke neste género deu-se em 1988 com a publicação de Weinschröter, du mußt hängen [Carreteiro de Vinho, a Forca espera-te]. ${ }^{8} \mathrm{E}$ em 1988, a editora Argument, de Hamburgo, lançou Ariadne, a primeira colecção alemã de romances policiais feministas.

Nos anos que se seguiram, veio uma verdadeira vaga de literatura policial feminista que atingiu inclusivamente os grandes grupos editoriais. Assim, a partir de 1992, a editora ECON, antes sedeada em Düsseldorf, começou formalmente a publicar romances policiais no feminino. Na colecção «A mulher na sociedade» da Fischer Verlag, em Frankfurt, foram - a par de outros géneros igualmente publicados romances policiais. Na segunda metade da década de 90 , a vaga voltou a refluir, tal como o movimento feminista, no seu conjunto, foi perdendo peso durante esses anos.

No entanto, desde finais da primeira década do séc. XXI, registou-se um reacender do movimento feminista na Alemanha, que se fez também sentir na literatura e no âmbito do romance policial. Exemplar é o caso de Herland, uma rede de autoras feministas de romances policiais no espaço de expressão alemã.

Como nome, a rede adoptou o título do romance Herland da escritora norte-americana Charlotte Perkins Gilman, um clássico da moderna literatura utópica e, simultaneamente, um exemplo precoce de utopia feminista. Descreve uma sociedade que cortou laços com o mundo exterior e é constituída exclusivamente por mulheres (a reprodução efectua-se por partenogénese); estas vivem numa ordem social ideal sem conflitos, brutalidade ou repressão. O romance

\footnotetext{
${ }^{5}$ Liza Cody (1986), Video-Piraten, Frankfurt/Berlim, Ullstein.

${ }^{6}$ Sara Paretsky (1986), Schadenersatz, Munique, Piper.

${ }^{7}$ Pieke Biermann (1987), Potsdamer Ableben, Berlim, Rotbuch.

${ }^{8}$ Doris Gercke (1988), Weinschröter, du mußt hängen, Hamburgo, Verlag am Galgenberg.
} 
viu a luz do dia nos EUA em 1915. ${ }^{9}$ Exactamente 100 anos depois, no Verão de 2015, é criada a rede Herland.

A iniciativa ficou a dever-se a Else Laudan, editora da já mencionada Argument Verlag. Segundo declaração da própria Else Laudan, desde 2011/2012 já andava a pensar numa associação de escritoras feministas de romances policiais. A partir de 2013, essa reflexão assumiu contornos mais definidos que desembocaram na fundação de Herland em 2015. ${ }^{10}$ A rede define-se, na sua homepage, como associação de «mulheres que desenvolvem a sua actividade em diversos locais da produção de livros de literatura policial. Assumimo-nos como politicamente empenhadas, feministas, ateias, fugidiças, contra a direita, anticapitalistas, antipatriarcais e bem sucedidas». ${ }^{11}$ Das fundadoras faziam parte, além de Else Laudan, a já mencionada escritora Doris Gercke, assim como as autoras de romances policiais Anne Goldmann, Anne Kuhlmeyer, Christine Lehmann, Merle Kröger, Zoë Beck e Monika Geier. Entretanto, a rede expandiu-se a cerca de 20 associadas na Alemanha e na Áustria. As mulheres procedem de várias gerações, têm uma escrita muito diversificada e apresentam biografias extremamente diversas. O que têm em comum é a afinidade com o romance de detectives, embora a definição deste, nas palavras de Else Laudan, seja muito abrangente e bastante fluida. Trata-se essencialmente de narrativas de crime e violência que podem assumir qualquer formato - desde o whodunit, passando pelo roman noir, até à narrativa auto-ficcional.

O denominador comum às associadas desta rede é a convicção de que a literatura de suspense representa o formato actual da narrativa contemporânea com uma dimensão política. Não é apenas entretenimento, mas narrativa sobre a sociedade. Como explana Anne Goldmann:

A história de detectives, o romance de policial, de suspense, o thriller entra, ligeiro, em cena logo à primeira vista. Quer entreter, agarrar, criar suspense por meio de histórias que prendem a leitora e o leitor atraindo-os para mundos estranhos ou tematizando a sensação de ameaça ao seu pequeno mundo, ou ainda manipulando medos e fascínio pelo assim chamado mal, pela complexidade que se pode ocultar por detrás da fachada polida de cada ser humano.

\footnotetext{
${ }^{9}$ Edição alemã: Charlotte Perkins Gilman (1980), Herland, Reinbek/Hamburgo, Rowohlt.

${ }^{10}$ Entrevista a Else Laudan a 10.04.2019 em Hamburgo. Todas as declarações ulteriores da autora, directas ou indirectas, são provenientes deste diálogo.

${ }^{11}$ https://herlandnews.com/; último acesso a 30.04.2019.
} 


\section{Simone Buchholz}

A autora, nascida em Hanau em 1972, concluiu o curso de Jornalismo na Henri-Nannen-Schule e trabalhou cerca de década e meia em regime freelance e contratada por diversas revistas e jornais. Hoje, vive como autora independente em Hamburgo. A par de livros infantis e juvenis, livros técnicos para adultos em forma de narrativa, contos, e novelas policiais S.B. escreveu, até ao momento presente, nove romances policiais.

No centro dos seus romances policiais, encontra-se a procuradora Chastity Riley, cujo pai era um oficial americano de serviço em Hessen. Assim se explica o invulgar nome próprio. Os romances têm lugar em Hamburgo-St. Pauli, o bairro de diversão junto ao porto, à volta da famosa Reeperbahn. A perspectiva é a da protagonista que narra na $1 . \stackrel{a}{\text { pessoa. }}$

Os romances iniciais tinham, desde logo, uma composição bastante convencional. Revolverherz [Coração de Revólver], o primeiro deles, foi publicado em 2008. Trata de um assassino em série que mata dançarinas do bairro de prostitutas e as escalpa. Knastpralinen [Bombons da choça], de 2010, aborda a violência contra as mulheres. Com Schwedenbitter [Amargo de Ervas Suecas], de 2011, a autora aventura-se, pela primeira vez, no terreno do crime organizado. Neste romance, entre outras coisas, a acção gira em torno da especulação imobiliária em Hamburgo. Estes três primeiros romances policiais são, quanto à estrutura e à temática, muito diversos. Nas palavras da própria Simone Buchholz, com estes primeiros romances, a autora tentou descobrir como gostaria de abordar o género e que tipo de de romances policiais gostaria de escrever. ${ }^{17}$

Os romances que se seguiram concentram-se mais intensamente em temas de relevância social. Assim, Eisnattern [Víboras de Gelo], de 2012, aborda a questão dos jovens negligenciados pela sociedade do bem-estar e a violência contra os sem-abrigo. Bullenpeitsche [Chicote da Bófia], de 2013, tematiza a criminalidade re-organizada e a teia que envolve a economia, a política e o crime nas malhas dos negócios do imobiliário e da corrupção. Com o sexto romance policial Blaue Nacht [Noite Azul], de 2016, Simone Buchholz atingiu o cume da popularidade. Os romances anteriores tinham sido publicados pela editora de Munique, Droemer Knaur, que investe de forma mais intensa no sector do entretenimento.

\footnotetext{
${ }^{17}$ Entrevista a Simone Buchholz a 17.06.2017; todas as declarações ulteriores da autora, directas ou indirectas, são provenientes deste diálogo.
} 
Desde Blaue Nacht, a sua obra passou para a Suhrkamp Verlag, editora conhecida pelas suas publicações de literatura moderna e exigente. Esta mudança, aliada à crescente maturidade literária da escritora e a uma postura cada vez mais acentuada como feminista e autora politicamente motivada, ${ }^{18}$ levaram a uma maior divulgação do romance, quer junto da crítica, quer do público. Blaue Nacht esteve durante vários meses na KrimiZeit Besten-List ${ }^{19}$ e, em dois deles, ocupou o primeiro lugar. Foi galardoado com o Deutscher Krimi Preis 2017 (2. ํㅡㅁ lugar na categoria «Nacional») e com o Cologne Crime Award 2016. Em 2018, a versão inglesa do livro (com o título Blue Night) é publicada pela Orenda Books London. O romance versa o tráfico de droga a nível internacional, regressando às malhas tecidas pela economia, a política e o crime, onde, mais uma vez, está envolvida a criminalidade organizada.

No Verão de 2017, é publicado Beton Rouge [Betão Vermelho], o sétimo romance. À primeira vista parecia tratar-se aqui de uma história de vingança do foro privado que, no entanto, devido ao seu encaixe em factos actuais, possui dimensões de crítica social. Os temas aqui abordados são o egoísmo social e o abandono pela sociedade de bem-estar, assim como a desenfreada maximização do lucro à custa dos mais fracos. O romance Mexicoring [Anel do México], publicado em 2018, debruça-se principalmente sobre os clãs criminosos e a autodeterminação feminina.

A figura central dos romances é, como já mencionado, a procuradora Chastity Riley. Em muitos aspectos, parece-se com os «duros» dos policiais norte-americanos na tradição de Raymond Chandler e de Dashiell Hammett: ela fuma e bebe demais, não tem papas na língua, mas é dada à melancolia e à depressão e tem um grande medo de ligações, em particular de relações amorosas. Porém, em contraste com os heróis dos romances de «duros», Chastity Riley não está isolada; pelo contrário, dispõe de um animado círculo de amigos e colegas. Daí que os romances de Buchholz não se limitem à temática do crime, mas também valorizem a amizade.

Um papel igualmente importante é desempenhado pela cidade de Hamburgo, nomeadamente o bairro de St. Pauli. Este bairro é tão fundamental para

\footnotetext{
${ }^{18}$ Ver a entrevista a Simone Buchholz «Wir brauchen keine Armee lieber Frauen», Main-Echo.de, 19.04.2019; https://www.main-echo.de/ueberregional/kultur/kultur-index/kultur/prio1/ art495432,6679493; último acesso a 30.04.2019.

${ }^{19}$ Desde Janeiro de 2017, «Lista dos melhores romances policiais»: trata-se de uma prestigiada lista das melhores obras do género que é organizada mensalmente por especialistas de ambos os sexos, devidamente identificados.
} 
os romances que quase se pode encará-lo como uma personagem autónoma com uma multiplicidade de rostos e facetas. Dele fazem parte como tema sempre presente, o tempo, as gaivotas, o asfalto, as zonas industriais, o porto e os seus guindastes. Assim ganha forma, não um retrato realista da cidade ou do bairro, mas um espaço ideal de nostalgia, por vezes excessivamente sobrecarregado.

St. Pauli é, juntamente com o porto, também um elemento decisivo na construção narrativa dos romances de Simone Buchholz, pelo menos dos mais recentes. O porto é o flanco exposto da cidade, através do qual o perigo e a ameaça, isto é, a criminalidade, se infiltra. Chastity Riley, as suas colegas e os seus colegas polícias fazem frente ao crime e procuram impedi-lo, o que muitas vezes só funciona em termos limitados, de modo que quando os livros chegam ao fim, nem tudo está bem, nem o o crime acabou de uma vez por todas, nem a criminalidade organizada foi definitivamente expulsa da cidade. Simone Buchholz escreve, portanto, policiais da grande metrópole que, na sua estrutura, fazem lembrar os romances do far-west norte-americano.

A criminalidade organizada assume nestes romances um papel cada vez mais relevante. Para Buchholz, o objectivo é mostrar que esta não existe num lugar longe de tudo e de todos, mas que também afecta o dia-a-dia de cidadãos perfeitamente normais. Buchholz parte das circunstâncias reais em Hamburgo, sem escrever um roman-à-clef. Também os mecanismos de funcionamento no interior dos clãs e das ligas masculinas, tal como os medos que produzem, despertam o interesse da autora. Um exemplo actual desse interesse é o romance de Buchholz, Mexikoring.

Com o passar dos anos, os romances policiais de Buchholz foram-se tornando cada vez mais políticos e feministas. Isto acontece, embora implicitamente, em relação às personagens multifacetadas e no plano da acção. Os romances são escritos num registo próximo da oralidade. Buchholz aposta nos diálogos e na acção; passagens com mera função moderadora ou narrativa são bastante raras. O tom é, sobretudo, lacónico, embora também caloroso. Apesar de toda a melancolia que perpassa pelos seus livros, os acontecimentos são, ao mesmo tempo, narrados com a ligeireza de um humor seco. 


\section{Monika Geier}

A autora, nascida em Ludwigshafen em 1970, trabalhou durante muito tempo como arquitecta. Hoje vive como autora independente no Palatinado. Como escritora de romances policiais, Monika Geier estreou-se em 1999 com Wie könnt ihr schlafen [Como é que vocês podem dormir?], publicado na já mencionada colecção de policiais feminista, Ariadne. Este romance foi galardoado em 2000 com o prémio «Marlowe» da Associação-Raymond-Chandler (Alemanha). Até hoje, Geier publicou oito romances policiais: sete deles, com a inspectora judiciária como protagonista e um outro acerca do historiador Richard Romanoff. Os romances são construídos como whodunits clássicos, mas vão, contudo, muito além disso, quer em termos de conteúdo, quer de estrutura.

Nos romances que giram à volta da inspectora, regra geral acontece pelo menos um assassinato e, à primeira vista, os móbeis residem na esfera privada: em Wie könnt ihr schlafen (1999) aborda a questão da violação e correspondente represália; em Neapel sehen [Ver Nápoles], de 2001, o tema é o comportamento abusivo e a defesa contra ele, assim como a desilusão amorosa; Stein sei ewig [Pedra, sê eterna], de 2003, centra-se em aspectos financeiros; Schwarzwild [Caça grossa], de 2007, foca o tema do ciúme; Die Herzen aller Mädchen [Os corações de todas as raparigas], de 2009, debruça-se sobre o roubo de um manuscrito de Ovídio e as práticas fraudulentas em matéria de seguros; Die Hex ist tot [A bruxa morreu], de 2013, expõe problemas de família e, em Alles so hell da vorn [Tudo tão claro ali adiante], de 2017, a prostituição forçada de crianças. Também Müllers Morde [Os assassinatos de Müller], de 2011, com o historiador Ronanoff a assumir a narração, se integra neste conjunto, tanto mais que, à primeira vista, são móbeis financeiros que conduzem aos delitos de homicídio.

Por detrás dos crimes há, contudo, muito mais do que a esfera privada, uma vez que os casos demonstram ser muito mais complexos do que é perceptível num primeiro instante. As criminosas e os criminosos de Monika Geier nunca são monstros ou psicopatas doentes, mas pessoas absolutamente normais que vivem no centro da sociedade e que, num momento da sua vida, decidem resolver os seus problemas com recurso a práticas delinquentes, como seja, olhar para o lado, negar, ou silenciar, favorecendo assim um acto criminoso. As circunstâncias de vida em que as personagens se encontram, desempenham um papel crucial. É frequente encontrarem-se sob uma qualquer forma de pressão, embora isto apenas explique e nunca desculpabilize os crimes. 
Monika Geier apresenta, assim, os delitos, acerca dos quais escreve, como uma decisão individual num contexto social específico. E deste modo consegue expor as relações recíprocas entre a sociedade, o indivíduo e a prática do crime.

Os romances policiais situam a acção num Palatinado fictício. As povoações vizinhas são normalmente designadas pelos seus nomes reais - por exemplo Ludwigshafen, Pirmasens, Mannheim; contudo, os palcos do crime são mera invenção. Há lugares factuais que podem servir de modelo, mas não são identificáveis, porque o que interessa a Monika Geier nunca é um simples realismo fotográfico. Daí que seja inútil procurar na sua obra realidades locais reconhecíveis. Mesmo praças, ruas ou edifícios de cidades designadas pelo seu nome real, possuem uma dimensão de estranheza. Nas palavras da própria Monika Geier, os seus romances desenrolam-se num «universo paralelo». ${ }^{20}$ Por esta razão, além de outras, estes romances não se integram de todo na categoria da chamada literatura policial regional: são muito mais complexos, com muito mais planos de significado e muito maiores ambições.

O objectivo primeiro dos policiais de Geier concentra-se nas personagens e no desenho destas. Usando escassas palavras, a autora consegue criar caracteres complexos e vivos, que funcionam para além da sua circunstância social e local. Monika Geier é uma observadora arguta das singularidades humanas e é exactamente isso que distingue os seus romances, povoados por personagens muitas vezes bizarras, que, apesar da sua bizarria, nunca resvalam para a estridência. Todos os romances são perpassados por uma mistura original de exorbitância e senso comum que, de forma incisiva, capta a realidade.

Um exemplo disso são as personagens principais: Bettina Boll é inspectora da Polícia Judiciária no K11 de Ludwigshafen, o departamento de crimes capitais. Desde que tem a seu cargo os filhos da irmã morta, a inspectora trabalha a tempo parcial - provavelmente como única investigadora de ficção no âmbito do romance policial de expressão alemã. Boll é desenhada como ligeiramente caótica: sempre um pouco atrasada, sempre um pouco desorganizada, sempre um pouco descontraída demais na maneira de vestir. Em compensação, possui um talento de observação muito apurado e uma inteligência combinatória. Boll raramente se enfronha nos detalhes, mas mantém a perspectiva da totalidade. Deste modo, consegue identificar estruturas e espaços, no interior dos quais ocor-

\footnotetext{
${ }^{20}$ Entrevista a Monika Geier de 16.06.2017; todas as declarações ulteriores da autora são provenientes deste diálogo.
} 
rem os crimes. Bettina Boll é descrita com uma pessoa de penetrante racionalidade, dispondo, ao mesmo tempo, de uma capacidade de espanto que raia o infantil, graças à qual não aceita nada como adquirido e tudo escrutina. Por isso, para quem está do lado de fora, às vezes ela dá impressão de ser um tanto ingénua; porém, o que pode ser mal-entendido como candura, é uma grande sede de conhecimento despida de preconceitos. O que em Boll é lido como intuição, é o resultado de uma combinação racional do que foi visto e ouvido com um pensamento não convencional e o recurso analítico a experiências vividas.

Monica Geier não se deixa intimidar pela complexidade: os seus romances policiais reflectem a fascinação da arquitecta pelos espaços e estruturas: organizados em vários planos, concebidos em filigrana, de construção elegante banhada em luz e um rigor convincente, a que tudo o resto se subordina. Por conseguinte, a vida privada das personagens principais só tem uma função quando faz avançar, ou recuar, as investigações relativas a um caso. Por exemplo, isto nunca acontece quando a falta de jeito põe em perigo um membro da família. Tudo o que é narrado contribui para a acção e serve de suporte à sua estrutura complexa.

Parte integrante deste contexto é também a descrição do sexismo quotidiano que a personagem de Bettina Boll enfrenta numa profissão dominada por homens. Quando o chefe, em tom incisivo, a trata por «Böllchen», a inspectora reage a estas e a outras humilhações, ou ao ignorar completo da sua pessoa, com uma resposta pronta e uma clara demarcação, sem disso dar conhecimento público. Também isto constitui um dos pontos fortes de Monika Geier: ela integra o sexismo subterrâneo, ou mesmo ostensivo, que existe dentro da polícia e da sociedade, tal como as reacções que suscita, numa forma de agir casualmente discreta e, por isso mesmo, mais certeira. Nada é aqui narrado a martelo, mas também nada é minimizado.

É assim que Monika Geier consegue a fusão de aspectos que parecem contrários: as suas personagens são tão extravagantes quanto terra-a-terra e, apesar de a acção ser complexa - nenhum romance permite que o seu tema seja descrito em poucas palavras, visto que por detrás dos casos descritos se abrem espaços e ligações em várias camadas que, pouco a pouco, vão sendo iluminados - para além de todo o entrelaçamento, mantém-se lógica e coesa; a cena dos crimes descritos é situada localmente, sem se ancorar de modo forçado na região e o modo narrativo é simultaneamente sereno e incisivo. Isto é tornado possível pelo estilo de escrita de Geier. Monika Geier narra com extrema segurança estilística, um humor negro e seco e uma ironia muito inteligente e refinada que, por vezes, de 
intrometem, se aferram aos casos e não abrem mão deles. Ao longo dos quatro romances, Merle Kröger afasta-se cada vez mais da forma do policial de investigação e expande as suas fronteiras.

Cut! é caracterizado por uma linguagem simples, fortemente gráfica. Cenas curtas e rápidas mudanças de perspectiva sublinham a montagem cinematográfica do livro. Isto é reforçado por oito cenas musicais que quebram o texto e evocam as produções de Bollywood. Também a nível do conteúdo se faz sentir esse reflexo: a procura do pai biológico da personagem principal leva-nos até Londres e Bombaim. Nesse processo, tem parte activa a chamada «Legião da Índia Livre», também denominada Legião Indiana, co-fundada em 1941 por Subhash Chandra Bose, antigo companheiro de luta e, por fim, adversário de Ghandi. Esta liga de combatentes, constituída por soldados de origem indiana que, na Segunda Grande Guerra, lutaram ao lado de Hitler contra a Inglaterra e, simultaneamente, contra Ghandi, recebia ordens das Waffen-SS alemãs. Além disso, as questões de identidade e origem também assumem um papel relevante.

Kyai! tem pontos de contacto com Cut! e entrelaça eficazmente um largo espectro de temas e personagens. Entre outras coisas, o romance versa a participação de tropas mercenárias privadas ou semi-privadas, e do exército alemão, em conflitos bélicos à escala mundial, aprofundando a questão da privatização da guerra.

Grenzfall ocupa-se de um caso real e ficciona-o, tornando-o exemplar: no Verão de 1992, junto à fronteira germano-polaca, dois indivíduos de etnia cigana são mortos a tiro ao tentar entrar clandestinamente na República Federal da Alemanha. Se se trata de um acidente de caça, como afirmam os dois agentes do crime, é algo que não pode ser provado e os dois atiradores ficam impunes no processo. Isto não são actos isolados. No Verão de 1992 houve vários crimes com motivações racistas no norte e no leste da Alemanha. Deste modo, a autora estabelece um arco temporal que vai dos começos da República de Berlim até ao presente. Ela atribui as causas dos atentados xenófobos não apenas aos indivíduos particulares, mas lança luz sobre os contextos tanto nacionais como internacionais, a disparidade de condições de vida na Europa, os efeitos dos desequilíbrios económicos em diversos estados europeus, a disposição violenta de alguns indivíduos tal como o medo do estrangeiro, e como tudo isto é calculisticamente instrumentalizado pelos partidos de extrema-direita para a conquista do poder. E é assim que Grenzfall expõe a promiscuidade entre as grandes estruturas e os esquemas mentais dos indivíduos. 
O ponto de partida para o quarto romance de Merle Kröger, Havarie foi o Mediterrâneo como zona fronteiriça e a questão das fronteiras «verticais», ou seja, segundo a autora, ${ }^{21}$ fronteiras cuja transposição isenta de riscos depende da capacidade financeira e da nacionalidade inscrita no passaporte. Havarie está estruturado de uma forma muito mais contida do que a dos livros anteriores. O estilo é bastante lacónico, muitas frases foram reduzidas ao essencial, os acontecimentos concentram-se em 48 horas. A acção: no Mediterrâneo cruzam-se os caminhos de quatro embarcações: um cruzeiro de luxo, um bote de borracha acidentado com refugiados da Argélia, um velho cargueiro de contentores arvorando o pavilhão ucraniano e um navio espanhol de socorro a náufragos. Os acontecimentos são narrados de múltiplas perspectivas, em cenas curtas, com cortes abruptos. Todas as personagens se encontram lado a lado, com o mesmo estatuto, ninguém assume uma posição destacada e por isso não existe qualquer protagonista. Com um número restrito de traços expressivos, as personagens são desenhadas contra o seu pano de fundo e situadas no respectivo contexto social, político e histórico. Cada uma encarna uma visão geopolítica que não está forçosamente associada à situação actual: do conflito na Ucrânia, passando pela guerra da Argélia; do conflito na Irlanda do Norte, passando pelo regime terrorista na Síria e o Holocausto, até ao afundamento do «Wilhelm Gustloff» ao largo da costa da Pomerânia - cada personagem viveu a experiência da violência, de crimes contra a humanidade, da guerra e da fuga e, é claro, das mais diversas perspectivas: como agente, como vítima, como seguidor oportunista. Ninguém está isento de culpa, ninguém é simplesmente bom ou mau, mas ninguém é sujeito ao pelourinho. A culpa não reside só nas personagens: tal como já acontecia nos romances anteriores, Merle Kröger cruza acções individuais com condicionalismos estruturais. Dão-se ainda duas mortes, mas não se faz qualquer averiguação sobre o caso. Claramente mais central é a questão de apurar que tipo de violência resulta da colisão entre mundos, estruturas, esperanças e constrangimentos diversos. Havarie é assim um notável thriller político, que apesar de toda a ficção, funciona como documentário e torna perceptíveis contextos extremamente complexos de economia e política, assim como os seus efeitos em estruturas abstractas e pessoas concretas.

\footnotetext{
${ }^{21}$ Entrevista a Merle Kröger de 28.06.2017; todas as declarações ulteriores da autora são provenientes deste diálogo.
} 
Os romances de Merle Kröger partem de factos e ocorrências que se enraizam no real e articulam a reavaliação histórica, a vivência individual e a análise política com elementos do romance policial e do thriller. A autora tem uma visão apurada das fracturas sociais e a sua narrativa, fruto de cuidadosa investigação e dotada de plausibilidade, tem um grande sentido da dramaturgia e do suspense.

A violência, enquanto tema dos romances de Merle Kröger, é muito mais um fenómeno estrutural do que individual. O que lhe interessa são os efeitos do capitalismo globalizado, que desabam sobre a vida dos indivíduos. É verdade que o capitalismo globalizado dá muitas oportunidades ao indivíduo mas, segundo a autora, o preço que tem de pagar por isso é muito elevado.

\section{Christine Lehmann}

Doutorada em ciências literárias, escreve romances policiais desde os anos 90 do século passado e é das mais prestigiadas autoras deste género literário no espaço de língua alemã. A par de histórias de detectives, a sua produção inclui ainda literatura juvenil, romances de amor, livros técnicos, peças radiofónicas, peças de teatro, glosas, ensaios e colaborações em inúmeras antologias. Preside à Verband deutscher Schriftsteller/innen (Associação de Escritores/as Alemães/ãs), na secção de Baden-Württemberg, foi durante muito tempo redactora de informação na SWR (Rádiodifusão da Alemanha do Sudoeste) e é hoje vereadora municipal em Stuttgart, onde também reside.

O primeiro romance policial de Christine Lehmann, Kynopolis, foi publicado em 1994. Só posteriormente criou a personagem de série, Lisa Nerz, que continua activa até hoje e se conta entre as protagonistas mais insólitas da literatura policial de expressão alemã. Lisa Nerz, a narradora dos romances, que utiliza a 1. ․ pessoa gramatical, é repórter, segura de si na sua maneira de agir, independente, recalcitrante e desabrida. É construída em contraposição aos estereótipos correntes das protagonistas do género policial: não é bonita, tem o rosto marcado por cicatrizes e é rica, logo, independente em termos financeiros. A sua personagem não cabe em nenhum molde pré-estabelecido: Lisa Nerz é bissexual e recusa tanto o papel feminino como o masculino. Nos romances, usa fatos de saia e casaco ou roupas de couro, às vezes mini-saia e botas de cano alto e depois, novamente saia e blazer. De acordo com a ocasião, investigação ou disposição do momento, comporta-se como mulher ou como homem e brinca com estes papéis. 
nista Argument Verlag, na qual foram também reeditados, depois de revistos, os três primeiros romances, de modo que a sua obra completa de literatura policial se encontra reunida nesta colecção.

Vergeltung am Degerloch [Retaliação em Degerloch], de 2006, sendo uma reedição de Der Masochist, onde Lisa Nerz faz a primeira entrada em cena, trata de um assassino em série que mata mulheres. Inspira-se num caso real e, segundo a autora, explica a obstinação de Lisa Nerz: esta deveria ser construída de modo a não só escapar ao assassino como, de certa maneira, a servir-lhe de empecilho. Em Gaisburger Schlachhof [Matadouro de Gaisburg], de 2006, reedição de Training mit der Tod, o tema determinante é a constituição do próprio corpo: desde o treino fitness até à mudança de sexo, o que está em causa são também problemas de identidade. Pferdekuss é reeditado em 2008 com o mesmo título da edição de 1999 e gira à volta de questões de reprodução e de herança, ou seja, de transmissão hereditária a que estão associados o poder, a brutalidade e a violência. Harte Schule [Escola Dura] de 2005, aborda o tema do abuso e do uso. Höhlenangst [Medo de cavernas], de 2005 é o único romance policial de Christine Lehmann que não acolhe uma dimensão ostensiva de política social. Bem diferente é Allmachtsdackel [O Cão do Todo-Poderoso], de 2007, até agora o maior êxito editorial da autora. O romance passa-se no meio pietista de Baden-Württemberg e, a par do fanatismo, questiona sobretudo temas ligados ao matriarcado em contraposição ao patriarcado, perspectivando uma Natureza organizada de modo muito menos patriarcal do que se admitiu por longo tempo. Em Nachtkrater, [Cratera Nocturna], de 2008, a autora e a protagonista deixam a Terra para fazer pesquisas numa estação espacial na Lua. Todos os romances de Christine Lehmann apresentam elementos de cunho fantástico e de ficção científica, mas em Nachtkrater é onde isso se torna mais visível. Muito mais terrestre é o romance policial Mit Teufelsg'walt [Com Violência Infernal], de 2009. Lança um olhar impiedoso sobre as relações de poder e violência no seio das famílias e das instituições de acolhimento com peso político. Identifica uma lacuna na lei que confia crianças e jovens a serviços de tutoria de menores.

Malefizkrott [Sapo Maléfico], de 2010, aborda o caso real da escritora Helene Hegemann, cujo livro, largamente discutido nas páginas literárias dos jornais demonstrou ser um plágio e é uma incursão amigavelmente trocista e recheada de alusões à indústria livreira de expressão alemã que levanta questões relativas à comunicação social. Em Totensteige [Escada dos Mortos], de 2012, os acontecimentos giram, à primeira vista, em torno da parapsicologia. Contudo, o tema 
estruturante deste thriller é o poder e o abuso de poder dos mídia na construção de realidades. O romance Die Affen von Cannstatt [Os Macacos de Cannstatt], de 2013, quebra o formato da série: Lisa Nerz é aqui apenas uma figura marginal, tendo como protagonista uma mulher que responsabiliza a repórter pela sua prisão preventiva, uma vez que estando ela inocente, aquela lhe assacou a prática de um assassínio. O cerne da questão é, novamente, o tema do matriarcado, reflectido, entre outros aspectos, nas relações de poder presentes na cadeia para mulheres e na vida social dos bonobos. Allesfresser [Omnívoros], de 2016, partindo da controvérsia para definir o regime alimentar correcto, confronta convicções quanto ao que deve ser a conduta correcta e assim aborda os temas do fanatismo e do extremismo. Die zweite Welt [O Segundo Mundo], de 2019, concentra-se na misoginia e no ódio a tudo o que é estrangeiro e novo, dois aspectos actualmente em efervescência na sociedade alemã.

Para Christine Lehmann, os romances não são tanto uma oportunidade para dilucidar um determinado tema ou sequer criar uma tendência. No cerne da sua obra estão temáticas sócio-políticas. O que vai ser posto à prova é o modo como as pessoas convivem umas com as outras, como se relacionam entre si, o que é condenado e o que não é. Analisado e questionado sem preconceitos. Neste processo, Lehmann viola conscientemente as regras (da compostura, do consenso social etc.) para levar aos limites as suas leitoras e os seus leitores. O que acontece regularmente, por exemplo, em questões de sexualidade: praticamente todos os romances com Lisa Nerz contêm cenas de sexo relativamente desenfreadas. A intenção da autora é dar voz a uma realidade na nossa esfera sexual que não corresponde à imagem ou às expectativas habituais. Mas sobre isso normalmente não se fala. Por essa razão, a personagem de Lisa Nerz não se deixa encaixar numa definição, por exemplo da sua sexualidade. Em quase todos os romances ela tem um caso com uma mulher e frequentes vezes também com um homem. Para a escritora, o que está aqui em jogo não é provocar, mas mostrar que, no âmbito sexual, as pessoas têm muitas facetas e as preferências podem mudar. O objectivo é dar voz a uma realidade que se desvia dos modelos inculcados, possibilitando a sua narração.

O princípio de ser diferente do esperado e dispor de um espectro de formas de conduta, preferências e orientações aplica-se igualmente à própria estrutura dos romances policiais. Também neste ponto Christine Lehmann está constantemente a quebrar as regras. Há sempre ecos de conhecidas marcas de género. Muitos romances jogam com elementos do whodunit, do locked-room-mystery, do 
thriller - frequentemente ao mesmo tempo e no mesmo texto - para livremente iludir as expectativas, romper os esquemas conhecidos e recompô-los de forma radicalmente nova.

Só num ponto é que Christine Lehmann é estrita: no modo de lidar com a violência e os mortos. Segundo a escritora, a maioria dos assassínios na vida real ocorre por ambição de domínio e de controlo. E isto reflecte-se nos seus romances: os criminosos ou as criminosas que Christine Lehmann descreve pretendem, por meio dum crime, influenciar relações e situações em proveito próprio, ou seja, resolver um conflito para organizar as condições existentes a fim de as terem sob o seu controlo. Daí que o homicídio seja um problema de dominação. Christine Lehmann explica que em todos os romances policiais tem em conta as estruturas de poder e os sistemas de dominação e, sempre que possível, desmascara-os como absurdos e brutais. Matar é, para a autora, uma coisa muito séria. Não sente qualquer empatia pelos assassinos ou pelo crime em si e é por isso que, nos seus romances, os descreve com a objectividade e o mínimo de voyeurismo possíveis. Nos policiais de Lehmann, o crime não tem em si nada de macabro, nem nele existe seja o que for de lúdico, o matar pelo gosto de matar, o assassínio como uma das belas-artes, ou coisa parecida. Daí que, nos seus livros, o conflito que conduz ao crime tem de ser estruturado de molde a forçosamente escalar em violência. Na opinião de Lehmann, girando o romance policial à volta da violência, ela pode, na qualidade de escritora, focar o efeito devastador dessa violência.

Enquanto personagem, Lisa Nerz é, por conseguinte, uma experiência que, no plano sexual, comunicacional e em vários outros planos, põe em jogo o que acontece quando as expectativas sociais não são realizadas, antes desfeitas.

\section{Transformação Cultural da Sociedade}

Apesar de toda a diversidade, há um denominador comum a todos os romances das autoras apresentadas: a naturalidade com que figuras femininas, conscientes de si, agem por conta própria. Sobre essa naturalidade, há ainda nos seus romances descrições de mundos vividos por mulheres, que muitas vezes o género silencia. Nenhuma das personagens principais das autoras apresentadas anda à procura de parceiros no amor para se sentir realizada ou aceite. Elas actuam como profissionais responsáveis. Acresce que nenhuma das figuras é 
representada como particularmente «forte», todas têm fraquezas e pontos fracos. O que também impressiona é que, em sítio nenhum se enfatiza o facto de se tratar de «figuras femininas fortes». Em princípio, todas as autoras deixam as suas personagens femininas agir simplesmente como seres humanos - e é aqui que se manifesta a transformação cultural almejada pela rede Herland: a igualdade de género entre homens e mulheres tornada absolutamente natural em todos os sectores da sociedade.

Tradução de Maria Antónia Amarante 


\section{A history of Swedish women crime writers - from the Golden age until the 2010s}

Sara Kärrholm

(Univ. Lund, Suécia)

The history of women crime writers in Sweden is a story that starts slowly but that works up its pace over time, especially since the turn of the new Millennium. The breakthrough for women crime writers in Sweden has happened in different phases that can be described as varying in significance and volume. The first happened in the years 1945-1960, a period that has been called the first Golden age when it comes to the production of Swedish crime novels. ${ }^{1}$ At this point, a handful of important women writers made their debut. A second phase took place almost half a decade later, in the late 1990s. This time the volume and impact were greater than before, and more long-lasting. ${ }^{2}$ The continuing wave of new women writers during the 2010s can be seen as a third phase, if you will, or as a prolonged phenomenon to the second. It is also possible to divide the women writers of the latest two decades into generations: the writers appearing around the Millennium, and the writers debuting around the 2010s and later. ${ }^{3}$

\footnotetext{
${ }^{1}$ Sara Kärrholm, Konsten att lägga pussel. Deckaren och besvärjandet av ondskan i folkhemmet. folkhemmet (eng. title: The Art of Doing a Jig-Saw Puzzle. The Detective Novel and the Conjuring Up of Evil in the Swedish Welfare State). Brutus Östlings bokförlag Symposion, Stockholm/Stehag 2005.

${ }^{2}$ For a description of the breakthrough and impact of women writers during this phase, see Karl Berglund, Deckarboomen under lupp. Statistiska perspektiv på svensk kriminallitteratur 1977-2010, Avdelningen för litteratursociologi, Uppsala universitet 2012 and Kerstin Bergman and Sara Kärrholm, Kriminallitteratur. Utveckling, genrer, perspektiv, Studentlitteratur, Lund 2011, pp. 45 and 193.

${ }^{3}$ Kerstin Bergman talks of «the 'daughters' of the Marklund generation» and mentions women writers debuting around 2006 and later in Swedish Crime Fiction. The Making of Nordic Noir, Mimesis International, s. 81. Since then, more women writers have had their debut around the 2010 s and later. It is difficult to know the best way to exactly address the different "waves» during these two latest decades, given that the boundaries are blurry between the different generations.
} 
There have, however, been deviations from this picture since the production of some of the most important female writers in the genre, such as Maj Sjöwall (in the joint authorship with Per Wahlöö) and Kerstin Ekman, has not exactly followed, but rather fallen in between, the patterns of these phases. Ekman started writing crime novels during the last years of the first Golden age but took a long break and came back to the genre before the second phase. Sjöwall and Wahlöö wrote their novels during the 1960s and 1970s, when the Swedish crime production in total was at a general low.

In this article, I will outline this development and trace how women writers have influenced the Swedish crime genre. I will identify patterns as well as point to singularities when it comes to these authors development of motifs, settings and characters in the genre and discuss the impact of the women writers on the genre as a whole. When it comes to the development during the latest two decades, I have decided to address them under two general headings - «The women crime writers at the turn of the Millennium» and «Women crime writers in the 2010s». Under the first, I address what might be called the «Marklund generation», and under the second, I approach the authorships that are best described as belonging to a newer generation of the 2010s. ${ }^{4}$

\section{«The Golden age»}

During the so-called Golden age for Swedish crime fiction, around the years 1945-1960, most of the novels were Swedish versions of the English and American brands of clue-puzzle whodunits. Some writers, such as Stieg Trenter, could also show influences from the American hard-boiled tradition, but only when it came to more superficial ingredients such as milieus and the use of a classic femme fatale-character (Kärrholm 2005, chap. 2: 95-148). The Golden age was the first period when the home production and sales of crime novels really took off. Male authors dominated the genre but there were also some significant women writers, such as Kjerstin Göransson-Ljungman, Maria Lang (pseudonym for Dagmar Lange), Helena Poloni (pseudonym for Ingegerd Stadener), Kerstin Ekman, Inga Thelander, Loulou Forsell and Elisabet Kågerman. I will address some of them more thoroughly in the following.

\footnotetext{
${ }^{4}$ See note 3 .
} 
The esteemed Swedish author, Kerstin Ekman, also made her debut as a crime writer during the late 1950s with the novel 30 meter mord (approx. 30 meters of murder, 1959), a very traditional whodunit, and she wrote several more during the 1960s. After the first three crime novels, Ekman's interest was more and more vested towards the psychological motifs and the impact of the environment on people's mindset, making her books depart from the whodunit tradition of the 1950s. In the novel Pukehornet (the name of a Swedish medieval horn), she wrote a novel that can be described as an anti-crime novel, with the terminology of Stefano Tani. ${ }^{11}$ After a significant time of turning to other kinds of writing (some of them with ingredients from the crime genre, but not clear cut crime novels), she returned to the crime genre with Händelser vid vatten, (Blackwater), in 1993, and Mordets praktik (approx. The practice of murder), in 2009. Händelser vid vatten has had a huge influence and gained international reputation. In Händelser vid vatten, Ekman uses the crime novel to give deep portraits of Swedish society in a Northern rural landscape. Mordets praktik is an intertextual comment on Swedish author Hjalmar Söderberg's novel Doktor Glas, written in 1905. Just like with Händelser vid vatten, in Mordets praktik, Ekman uses the crime narrative in an exploratory way. ${ }^{12}$ Her other literary production and the «literariness» of her crime novels have sometimes raised debates about genre distinctions, in a way that resembles the discussions about Thelander's novels (Persson 2002, chap. 4: 180-242).

\section{The women crime writers at the turn of the millennium}

1997 was a decisive year for the Swedish crime genre because of an initiative started by the crime literature magazine Jury together with the Swedish publishing house Ordfront. They wanted to inspire and promote women crime

bokförlag Symposion, Stockholm/Stehag, 2009, pp. 235-247, «Inga Thelander», www.skbl.se/sv/artikel/IngaThelander, Svenskt kvinnobiografiskt lexikon (article by Sara Kärrholm), achieved 2018-11-20. ${ }^{11}$ This according to Magnus Persson, who analyses Ekman's crime novels in his book Kampen om högt och lågt. Studier I den sena nittonhundratalsromanens förhållande till masskulturen och moderniteten, Brutus Östling bokförlag Symposion, Stockholm/Stehag 2002, p. 207. See also AnnSofi Andersdotter, Det mörka våldet. Spåren av en subjektprocess $i$ Kerstin Ekmans författarskap, Brutus Östlings bokförlag Symposion, Stockholm/Stehag 2005.

${ }^{12}$ Emma Tornborg, «Jämtland. Kroppens, politikens och minnets naturlandskap - Kerstin Ekman», in Kerstin Bergman (ed.), Deckarnas svenska landskap. Från Skåne till Lappland, Makadam, Göteborg/ Stockholm 2014, 185-193, p. 185. 
writers through the installation of a literary award and the launch of a crime writer's course for women. The Poloni-prize was to be awarded to the best woman crime writer of 1998 and the founders had the expressed ambition to promote women writers but also female protagonists in the Swedish crime genre. In the announcement of the prize, journalist and crime critic Johan Wopenka mentioned the recent success of Norwegian woman writers as a source of inspiration. If they can do it in Norway, the argument went, than why not here in Sweden? (Wopenka 1997: 13-17).

At this point in time, there was a clear lack of notable Swedish women crime writers. Accept for Maj Sjöwall, who wrote together with her spouse Per Wahlöö, a few women had made names for themselves since the days of Helena Poloni and Maria Lang. The genre had become more and more male dominated, with Henning Mankell being the most notable of them all. Other male crime writers who were successful during the 1980s and 1990s were Jan Guillou, Jan Mårtensson and Leif G. W. Persson.

The initiative of Jury and Ordkonst was successful in several ways, although it is difficult to say to what degree it was directly responsible for the following «boom» of women crime writers. Liza Marklund, the Swedish journalist who won the first Poloni-prize for her crime debut Sprängaren (The Bomber), quickly became a role model for new women in the genre. The writing course was also a success in the sense that many of the participants became popular crime writers in the following years, among them Camilla Läckberg. This paved way for the new wave of women crime writers at the early years of the 2000s. The Poloni-prize was awarded to three more writers in the years after Marklund's prize: to Aino Trosell, Åsa Nilsonne and Eva-Marie Liffner, and was then cancelled, since the promoting of women writers in the genre was no longer deemed necessary (Bergman 2014a: 71). According to Wopenka, more than eighty women made their debut as crime writers in Sweden during the years 1998-2007 (Wopenka 2009: 7; Bergman 2014: 71-72). These years can thus clearly be said to mark a decisive breakthrough for women in the genre. As will be shown under the next heading, the development did not stop then and there.

Liza Marklund's extensive background as a journalist at a daily newspaper and the tabloids Expressen and Aftonbladet, as well as Swedish television (Tv4), has served as a good starting point for writing about current debates and politics in her crime novels about the investigative reporter and amateur detective Annika Bengtzon. Marklund’s first crime novel, Sprängaren (The Bomber), por- 
trays women working in male dominated work places through three different characters: the detective, the victim and the murderer. All of them are in different ways struggling with patriarchal structures and individuals, both men and women, who harass them because they feel threatened by them. Bengtzon, working at a tabloid paper, is struggling with making ends meet with her career and family life, while being discouraged by her co-workers, although her boss is understanding and supportive. The following novels in the series, Studio sex (Exposed, 1999) and Paradiset (Paradise, 2000), tells the background story about Bengtzon's past, leading up to the point that starts in the beginning of Sprängaren. These stories tell Bengtzon's personal history of violence in a former relationship. Men's violence against and sexual abuse of women as well as the structural problems of patriarchal patterns in society has been at the core of Marklund's writing, both as a novelist and as a journalist. She also wrote the novel Gömda (Hidden, 1995) and later Asyl (Asylum, 2004), based on a true story about a woman's escape from an abusive husband.

The novels about Bengtzon centres on her struggle to advance as a woman in her workplace, where she assumes more and more responsibility, while her family life becomes more and more complicated. Bengtzon is portrayed as a person with just as many flaws as benefits, which makes her a complicated character and sometimes somewhat problematic from a feminist approach. Marklund has herself pointed out that it was her intentional choice to allow Bengtzon to be a human being rather than first and foremost a woman. Bengtzon is not to be read as a feminist role model, but the stories about her highlight some of the unreasonable expectations that are put on women working in a man's world (Kärrholm 2011: 135). It is the stories and their themes, often focusing on men's violence against women, but also on how women help to undermine other women in a patriarchal culture, that represent Marklund's feminist ideology (Kärrholm 2011; Stougaard-Nielsen 2017: 174).

Marklund introduced some of the features that would become characteristic for the women writers as a group, but she also differed from the rest in many ways. Her focus on a female protagonist with a family life and love relationships that influences her detective work was repeated by many of the followers. Marklund, however, also involves social critique and politics in her work to an extent that has not been seen in many of the other's.

One of the most important writers of the «Marklund-generation» is Åsa Larsson. Larsson's crime novels are set at the Northern tip of Sweden, Lapland, 
and the nature there plays a great part in her stories where the lawyer, Rebecka Martinsson, solves crime together with the policewoman Anna-Maria Mella. At the end of the first novel, Solstorm (Sunstorm), Rebecka finds herself forced to kill three male offenders. The psychological crisis that this trauma causes for her, haunts her through the different investigations in the subsequent development of the series, where Rebecka's mental health is often described as unstable.

Rebecka was raised in Lapland, but later moved to the capital, Stockholm, in order to pursue a career within a successful law firm. The contrast betweeen her youth in the north of Sweden and her adult life in Stockholm is a recurrent motif in the novels. The crisis brought forward by the traumatic murder cases Rebecka gets involved in eventually transcends into an existential crisis, where Rebecka feels the need to choose between the old and the new, to return to the landscape and people of her past or to continue and pursue her career as a big city lawyer in Stockholm.

In all the novels by Larsson, there is a hint that the reason for Rebecka to leave her hometown is also partly the reason for the murders occurring there. The role of the church is crucial here, as well as the narrow-mindedness of the inhabitants when in contact with something strange and different. It is also a matter of traditions reproducing a system of abuse against women and focused in containing the feminine sexuality in many ways. Leaving her past behind is thus linked to losing her religious faith for Rebecka, who tries to get back to a feeling of faith through the experience of the Northern nature (Kärrholm 2014: 217-224).

The great abundance of animals and the very present Northern landscape in Larsson's novels tells us that the humans are not inhabiting this part of the world alone. Their psychological motifs for acting in certain ways are accompanied and sometimes counterfeited by the actions and intentions of nature and of animal beings. The connection between humans and animals and between humans and nature opens up new dimensions that are sometimes described as almost magical. In the fourth novel of the series, Till dess din vrede upphör (Until thy Wrath be Past, 2008) this function is symbolically carried out by crows, who react to the presence of the spirit of a murdered teenage girl.

One of the most successful woman writers outside of Sweden, specifically in Spain and France, has been Camilla Läckberg. Her crime series about the biographer Erica Falck and her husband, the policeman Patrik Hedström, are placed in the beautiful Swedish coast town Fjällbacka, where a special brand of crime 
tourism has developed in the wake of Läckberg's success (Sjöholm 2011: 87-120). The first novel in the series, Isprinsessan (Ice Princess) from 2003, involves the story about how Erica returns to her childhood small town to find her childhood friend is killed and placed frozen in the bathtub of an empty house. In most of Läckberg's novels, the story unfolds into parallel stories, one in the present and another from the past, whose paths converge at the end of the investigation. The past is often revealed to hide some key to the development of the murder plot or to the identity of the murderer, as is for example the case in Stenhuggaren (The Stonecutter, 2005) and Tyskungen (The Hidden Child, 2007), where the murders are connected to events in the 1920s (Stenhuggaren) and the 1940s (Tyskungen). Even if the stories are written as police procedurals, involving a group of police officers investigating the case, they are perhaps best described as cosy whodunits, where the hidden pasts and motifs of people in a small town ridden with social intrigues and mistrust play a central part. The private life of the couple Erica and Patrik also plays a central role in the novels, that follows their marriage closely. Läckberg has also been described as a master of developing interesting side characters, introducing more layers to each of them for every new title in the series (Carlsson 2009: 151).

Cosy crime is also the best way to describe the two different crime series written and placed on the Swedish island Gotland by the writers Mari Jungstedt and Anna Jansson. Jansson's series about the policewoman Maria Wern, starting with Stum sitter guden (approx. Silent Sits the God), in 2000, have resulted in a long running tv-show and she has also created a spin-off series for young readers about Maria’s son, Emil Wern, as a child detective (Kärrholm 2016: 1-24). Maria Wern's marriage and later divorce from an abusive husband take central part in the series. Jansson's own background as a nurse has inspired several of the murder plots that often invoke ethical dilemmas in sick care (Fredriksson 2009: 90-91). She also uses the landscape and folklore of Gotland as means for inspiration as well as for creating atmosphere. Both Jungstedt and Jansson also make use of the geographical fact that Gotland is an island that can be isolated from steady land in order to create locked room-mysteries. In Jansson's Främmande fågel (Strange bird), from 2006, for instance, Gotland turns into an area inflicted with the bird flu and has to stay in quarantine, forbidding people to leave the island and people from the outside to get there. The novel seemed almost prophetic at the time of its publication, since it coincided with an actual incident involving the bird flu in Sweden (Tornborg 2014: 64). 
Jungstedt's protagonists are the crime solving duo, the investigator and head of the Visby crime force, Anders Knutas, and the TV-reporter, Johan Berg. The fact that Jungstedt is a woman writing about two male protagonists makes her stand out as unusual among her peers (Bergman 2009: 107). Knutas is happily married, but Berg starts off as single. His romantic and sometimes stormy relationship with Emma, who he meets in the first novel, Den du inte ser (Unseen), from 2003, forms the background to the whole series (idem: 99). Like Jansson, Jungstedt places a lot of emphasis on Gotland in her crime novels, often as a cozy setting and the murders often take place in summertime.

Just as Jungstedt and Jansson, Helene Tursten and Åsa Nilsonne write police procedurals but their novels are placed in the two big cities Gothenburg (Tursten) and Stockholm (Nilsonne). Both work with female protagonists who are police women. In Tursten's novels, starting with Den krossade tanghästen (Detective Inspector Huss), in 1998, Irene Huss is described as a tough police woman who - like Marklund's Annika Bengtzon - balances work with her everyday life as a mom of teenage twins. The focus on the everyday is very present in the series, making the effect of recognition and identification important (Wedding 2009: 220). Her murder plots are also firmly connected to the everyday recognizable societal problems in big cities.

In Nilsonne's novel, starting with Tunnare än blod (approx. Thinner than blood), written as early as in 1991, detective Monika Pedersen struggles more with her inner self and her life expectations, since there are no children or a husband to consider. Pedersen's personal crisis is sometimes described as a parallell to the situations of other women in the stories, making her personal situation reflect general disappointments for women in different parts of Swedish society (Kärrholm 2009b: 184-198). This strategy, to use the personal to raise consciousness about patriarchal structures in Swedish society, she shares with Liza Marklund.

Karin Alvtegen and Inger Frimansson depart from the police procedural tradition and write psychological thrillers. Both are distinguished writers in the genre. Alvtegen has written many one-word titles, starting (in the Swedish version) with an «S»: Skuld (Sacrifice, 1998), Saknad (Missing, 2000), Svek (Betrayal, 2003), Skam (Shame, 2005), and Skugga (Shadow, 2007). All of them can be described as investigations into the dark corners of the human psyche and involve protagonists who are dealing with inner emotional storms of different kinds, but mostly concerning uncontrollable feelings of shame (Peterson 2009: 34). Frimansson's 
started a new series of two novels - Lotus blues (Lotus blues, 2014) and Mios blues (Mio's blues, 2015) - that takes her authorship into a new direction. The male protagonist, the attorney Martin Benner, as well as the hard-boiled style of these noir-thrillers makes them stand out among contemporary crime novels written by women authors. Ohlsson also wrote a psychological thriller, Sjuka själar (Sick souls), in 2016, and a number of successful children's books within the mystery genre (Kärrholm 2016: 1-24).

Among the more explicitly feminist writers is Katarina Wennstam, whose crime fiction often concern men's sexual abuse and exertions of power over women. Her first trilogy, Smuts (Dirt, 2007), Dödergök (Omen of death, 2008) and Alfahannen (The alpha male, 2010) features the district attorney Madeleine Edwards as main detective. The novels use the murder plots to discuss problematic views of women and sexuality in contemporary Swedish society. With Svikaren (The quitter), Wennstam started a new series in 2012, featuring investigator Charlotta Lugn and the attorney Shirin Sundin. Wennstam has written several factual books on feminine sexuality and shame as a crime journalist and the same themes are often at the heart of the murder investigations in her crime novels (see Bergman 2014a: 84).

One of the most successful of the new women writers of this second wave is Viveca Sten, who places her cozy crime-novels on the island Sandhamn, in the Stockholm archipelago. Her series about detective Thomas Andreasson and district attorney Nora Linde, starting with I de lugnaste vatten (Still waters, 2008), has so far stretched over ten titles and has been adapted into a TV-series, Morden $i$ Sandhamn (The Sandhamn murders), in 2010. The stories often play with the contrast between the very idyllic setting and the dark and twisted murder plots. Sten has a career as a General Counsel and is fluent in many languages, which has helped in the introduction of her crime novels to many other countries. ${ }^{14}$

Another noteworthy writer is Sofie Sarenbrant. Her debut was with the book Vecka 36 (Week 36, 2010), about the disappearance of a pregnant woman, but her most popular books are the series about the detective Emma Sköld, starting with Vila i frid (Rest in peace, 2012). In Sarenbrant's novels the concept for each book plays a great importance. In Vila i frid the murder occurs at a popular spa resort, in Andra andningen (approx. The second coming, 2013), a marathon through Stockholm sets the background to the murder, and in Visning pågår (Killer deal,

\footnotetext{
${ }^{14}$ Viveca Sten's homepage: https://www.vivecasten.se/viveca, achieved 2018-12-11.
} 
2014), a person is killed in a house that has just been showed to potential buyers. The fifth novel about Emma, Tiggaren (The beggar, 2016), involves a serial killer targeting beggars in central Stockholm. Alongside the murder plots, the life and the, at times, dramatic love life of Emma is explored and developed throughout the series. In 2017, Sarenbrant temporarily paused the series and introduced the first part of a planned trilogy with Bakom din rygg (Behind your back).

Among the more prominent writers of recent years is Kristina Appelqvist who writes crime novels in an academic setting, Västgöta university, which is a fictional representation of Skövde university. Her first series, starting with Den svarta löparen (approx. The black runner, 2009), has the university principal and medieval historian, Emma Lundgren, solving crimes together with the police detective Filip Alexandersson. She has also written the series about another academic, literary scholar Helena Waller, starting with Minns mig som en ängel (approx. Remember me as an angel) in 2014, set in the same fictional universe as the other series. Appelqvist's novels can be described as feelgood-whodunits in the tradition of Agatha Christie and Dorothy Sayers, where the rural setting around Skövde plays a central part (see Bergman 2014b: 71-78).

Malin Persson Giolito, a Swedish attorney working for the European Union Commission in Bruxelles, recently had a major breakthrough as crime writer with the procedure drama, Störst av allt (Quicksand), in 2016. The novel received several literary awards, has been sold to many different countries and been adapted into a Netflix original tv-series. ${ }^{15}$ A reason for the great success of this novel is that it tells the story of a school shooting interestingly from the perspective of a suspect teenage girl. While the reader follows the investigation's unfolding through her eyes, she also shares more and more of the information that only she knows about. This narrative technique works to build a great deal of suspense and curiosity. Persson Giolito started writing crime novels with Dubbla slag (approx. Double beats) in 2008 and is the daughter of the well-known Swedish criminologist and crime writer Leif G. W. Persson.

Another interesting name among the newcomers to the genre is Sara Lövestam. Her debut crime novel, Sanning med modifikation (approx. Truth with modification, 2015) introduces the unlikely protagonist and amateur sleuth, Kouplan. Kouplan is a paperless immigrant, living on the streets, and constantly terrified

\footnotetext{
${ }_{15}$ «Malin Persson Giolito», author information at the homepage for Wahlström \& Widstrand. https://www.wwd.se/forfattare/45770/malin-persson-giolito/. Achieved 2018-11-30.
} 
to be discovered by Swedish police and deported from the country. During his investigations into different strange mysteries (it rarely happens to be an actual murder), he also discovers new parts of the Swedish language, which fascinates him. The novels also involve trans-identity in interesting ways and the personal development of the character is a mystery of its own that deepens with every book in the series. The books are written with a slow pace and humour, paying a lot of detail to language and style. Lövestam's background as a Swedish teacher has inspired her work and also resulted in several popular books on language and grammar. ${ }^{16}$

Jenny Rogneby and Emelie Schepp both write about women detectives that depart from the norms set by former women writers. In Rogneby's debut, Leona - tärningen är kastad (Leona - the die is cast, 2014), a young girl is manipulated by criminals to commit a robbery and the inspector at the Stockholm city police, Leona Lindberg, is far from innocent herself. The moral dubiousness of her as a character is used as one of the key ingredients to giving the audience a thrilling read. Emelie Schepp started her series about district attorney Jana Berzelius with the self-published novel Märkta för livet (Marked for life, 2013) Like Rogneby’s Leona, Jana is a complicated character who walks a thin line between good and evil in her approach to her work. Schepp has been intensely engaged in promoting her own novels through giving interviews and in social media, which has resulted in a vast readership and several reader's choice awards. ${ }^{17}$

\section{Concluding remarks}

The Swedish tradition of crime writing has mostly been described as a tradition departing and drawing inspiration mainly from the work of Maj Sjöwall and Per Wahlöö, whose decalogy The Story of a Crime (1965-1975) has had a tremendous influence on writers both in and outside of Sweden. In Sjöwall and Wahlöö's footsteps, writers such as Henning Mankell, Stieg Larsson and Arne Dahl have continued to use the genre to express a leftist critique of the Swedish welfare state, often from the perspective of decaying masculine ideals (Tapper 2011). This tradition, associated with high ambitions and ideology, has mainly been described as a masculine tradition and represented by male authors (ibidem).

\footnotetext{
${ }^{16}$ Sara Lövestam's homepage: https://saralovestam.se/about/, achieved 2018-12-14.

${ }^{17}$ Emelie Schepp's homepage: https://www.emelieschepp.se/nyheter, achieved 2018-12-14.
} 
Karl Berglund has recently pointed out that male and female authors are handled and viewed very differently on the Swedish book market. In his study of how crime novels are packaged through sales texts and other marketing material he concludes that there are vast differences in how male and female authors are presented to their readers and which associations they are tied up with. He describes that there are two segments in the marketing of Swedish crime novels in the 2000s: "one masculine that mainly focus on social engagement, literary quality, professionalism and male role models; and one feminine that mainly highlights women role models, everyday realism and ingredients that are seen as personal and private, but not political (even if they could of course be interpreted that way)» (Berglund 2016: 174; my translation). On the Swedish book market, there has been a tendency to treat women crime writers as a group while male writers have been treated as individual writers to a higher extent (see Kärrholm 2009c: 467-484).

The long list of women crime writers that has been brought up in this article suggests that the image of the feminine tradition in Sweden, brought to the light by Berglund, is not entirely accurate. Even if some women writers are inspired by other women writers and there is a discernible pattern among women writers that has its focus on female protagonists working the life puzzle while solving murders, there is also room for great variation among these writers, who very well deserve to be talked of as individual authorships. Alvtegen's authorship, for instance, shares little in common with Marklund's, and Lövestam's fiction has little or nothing in common with Appelqvist's or Persson Giolito's. As mentioned, in the great abundance of Swedish crime fiction on the contemporary scene, it has become more and more important to stand out (even if not all writers succeed in doing this) (Berglund 2017: 34).

And, even if some of the women writers have been accused for cementing gender stereotypes rather than questioning them, this is certainly not true for all of them. ${ }^{18}$ As suggested by Berglund's quote, the women authors often use a personal and private perspective precisely in order to say something political, in accordance with the well-known device in Swedish women's literature «the personal is political». ${ }^{19}$ It is not only Liza Marklund that has appropriated this

\footnotetext{
${ }^{18}$ This critique has for instance been formulated by Kerstin Bergman in Bergman 2014a, p. 77.

${ }^{19}$ See for example Cristine Sarrimo, När det personliga blev politiskt. 1970-talets kvinnliga bekännelse och självbiografi, Brutus Östlings bokförlag Symposion, Stockholm/Stehag 2000. See also Sara Kärrholm, «Den kvinnliga detektivens kropp», in Finsk tidskrift No. 3-4 2013, pp. 43-55.
} 
device, but also writers such as Åsa Larsson, Åsa Nilsonne, Katarina Wennstam, Tove Alsterdal, Karin Alvtegen, Inga Thelander, Aino Trosell, and Sara Lövestam, to mention a few. These authors use the crime genre to direct a feminist critique against patriarchal societal structures. In this sense, Stieg Larsson, can be said to have become famous for expressing a political agenda that was already - albeit in other versions - present in the feminine tradition of Swedish crime writing. ${ }^{20}$ In fact, it can be deceiving to divide the genre into a masculine and a feminine tradition, just as deceiving as it would be to describe all the women writers as either feminists or traditionalists. Berglund has pointed out that maybe «the women crime writers have become such an important part of the commercial top sheet of the genre that they are no longer seen as deviating from the the genre's centre» (Berglund 2016: 95). The women writers have grown so many in numbers that their impact is most likely to increase while hopefully, the overall stereotypical means of treating women writers by critics and others will become out of date. In the future history writing of the Swedish crime literary tradition, the women writers deserve a more dedicated and prominent place than what they have been allotted so far.

\section{Works Cited}

ALVTEGEN, Karin (1998), Skuld, Legenda/Natur och kultur, Stockholm. (2000), Saknad, Legenda/Natur och kultur, Stockholm. (2003), Svek, Natur och kultur, Stockholm. (2005), Skam, Natur och kultur, Stockholm. (2007), Skugga, Natur och kultur, Stockholm.

ANDERSDOTTER, AnnSofi (2005), Det mörka våldet. Spåren av en subjektprocess $i$ Kerstin Ekmans författarskap, Brutus Östlings bokförlag Symposion, Stockholm/Stehag. APPELQVIST, Kristina (2009), Den svarta löparen, Alfabeta, Stockholm. (2014), Minns mig som en ängel, Piratförlaget, Stockholm.

BERGLUND, Karl (2012), Deckarboomen under lupp. Statistiska perspektiv på svensk kriminallitteratur 1977-2010, Avdelningen för litteratursociologi, Uppsala universitet, Uppsala, diss.

\footnotetext{
${ }^{20}$ Kerstin Bergman has claimed that Lisbeth Salander is not as unique as character as she might at first seem to an audience outside of Sweden. Bergman compares Salander to other «sisters» in Swedish crime fiction in Kerstin Bergman, «Lisbeth Salander and her Swedish Crime Fiction 'Sisters'», in Donna King and Carrie Lee Smith (eds.), Men Who Hate Women and Women Who Kick Their Asses, Vanderbilt University Press, Nashville 2012, pp. 135-144.
} 
(2014), "A turn to the rights. The advent and impact of Swedish literary agents», in Jon Helgason, Sara Kärrholm, and Ann Steiner (eds.), Hype. Bestsellers and Literary Culture, Nordic Academic Press, Lund, 67-87.

(2016), Mordförpackningar. Omslag, titlar och kringmaterial till svenska pocketdeckare 19982011, Avdelningen för litteratursociologi, Uppsala universitet, Uppsala, diss. (2017), Mordens marknad. Litteratursociologiska studier i det tidiga 2000-talets svenska kriminallitteratur, Uppsala universitet, Litteraturvetenskapliga institutionen, Uppsala, diss.

BERGMAN, Kerstin (2009), «Isolerad idyll och svart barndom. Mari Jungstedt», in 13 svenska deckardamer, BTJ Förlag, Lund: 96-111.

, together with Sara Kärrholm (2011), Kriminallitteratur. Utveckling, genrer, perspektiv, Studentlitteratur, Lund.

(2014a), Swedish Crime Fiction. The Making of Nordic Noir, Mimesis international, Italy. (2014b), «Västergötland. Kyrkornas landskap - Kristina Appelqvist», in Kerstin Bergman (ed.), Deckarnas svenska landskap. Från Skåne till Lappland, Makadam, Göteborg/ Stockholm: 71-78.

(2014c), «Dalarna: Arbetarminnenas landskap - Aino Trosell», in Kerstin Bergman (ed.), Deckarnas svenska landskap. Från Skåne till Lappland, Makadam, Göteborg/Stockholm: 147-154.

(2012), «Lisbeth Salander and her Swedish Crime Fiction 'Sisters'», in Donna King and Carrie Lee Smith (eds.), Men Who Hate Women and Women Who Kick Their Asses, Vanderbilt University Press, Nashville, 135-144.

CARLSSON, Marie (2009), «Fjällbackas finest. Camilla Läckberg», in 13 svenska deckardamer, BTJ Förlag, Lund: 147-167.

«Dagmar Maria Lange (Maria Lang)», www.skbl.se/sv/artikel/DagmarMariaLangeMariaLang, Svenskt kvinnobiografiskt lexikon (article by Sara Kärrholm), achieved 201811-20.

EKMAN, Kerstin (årtal?), 30 meter mord, Bonnier, Stockholm. (1967) Pukehornet, Bonnier, Stockholm. (1993), Händelser vid vatten, Bonnier, Stockholm. (2009), Mordets praktik, Bonnier, Stockholm.

Emelie Schepp's homepage: https://www.emelieschepp.se/nyheter, achieved 2018-12-14. ERIKSSON, Bengt (2009), «De små, små detaljerna. Karin Wahlberg», in 13 svenska deckardamer, BTJ Förlag, Lund: 238-260.

FORSHAW, Barry (2012), Death in a cold climate. A guide to Scandinavian crime fiction, Palgrave Macmillan, Basingstoke.

FREDRIKSSON, Karl G. (2009), «Kriminalromaner med klang av Ferlin. Anna Jansson», in 13 svenska deckardamer, BTJ Förlag, Lund: 77-95.

FREDRIKSSON, Lilian (2009), «Samtidsskildrare med underifrånperspektiv. Aino Trosell», in 13 svenska deckardamer, BTJ Förlag, Lund: 199-218. 
GÖRANSSON-LJUNGMAN, Kjerstin (1939), Tjugosju sekundmeter, snö, Bonnier, Stockholm. «Inga Thelander», www.skbl.se/sv/artikel/IngaThelander, Svenskt kvinnobiografiskt lexikon (article by Sara Kärrholm), achieved 2018-11-20. «Ingegerd Gurli Stadener», www.skbl.se/sv/artikel/IngegerdStadener, Svenskt kvinnobiografiskt lexikon (article by Sara Kärrholm), achieved 2018-11-20.

JANSSON, Anna (2000), Stum sitter guden, Prisma, Stockholm. (2006), Främmande fågel, Prisma, Stockholm.

JUNGSTEDT, Mari (2003), Den du inte ser, Bonnier, Stockholm. «Kjerstin Gertrud Elisabet Göransson-Ljungman», www.skbl.se/sv/artikel/KjerstinGoranssonLjungman, Svenskt kvinnobiografiskt lexikon (article by Sara Kärrholm), achieved 2018-11-20.

KÄRRHOLM, Sara (2005), Konsten att lägga pussel. Deckaren och besvärjandet av ondskan i folkhemmet. Brutus Östlings Bokförlag Symposion, Stockholm/Stehag. (2009a), «Den misslyckade deckarförfattaren. Genreförväntningarnas betydelse för värderingen av Inga Thelanders författarskap», in Anders Mortensen (ed.), Litteraturens värden, Brutus Östlings Bokförlag Symposion, Stockholm/Stehag: 235-247. (2009b), «Kvinna på gränsen till nervsammanbrott. Åsa Nilsonne», in 13 svenska deckardamer, BTJ Förlag, Lund: 184-198.

(2009c), «Mediernas betydelse för skapandet av två "deckardrottningars" varumärken», in NORLIT 2009: Codex and Code, Aesthetics. Language and Politics in an Age of Digital Media, Stockholm, August 6-9, 2009, 467-484. (2011), «Swedish Queens of Crime: the Art of Self-Promotion and the Notion of Feminine Agency - Liza Marklund and Camilla Läckberg», in Andrew Nestingen and Paula Arcas (eds.), Scandinavian Crime Fiction, University of Wales Press, Cardiff: 131-147. (2013), «Den kvinnliga detektivens kropp», in Finsk tidskrift, No. 3-4 2013, 43-55. (2014), «Lappland: Den vilda naturens helande kraft - Åsa Larsson», in Kerstin Bergman (ed.), Deckarnas svenska landskap. Från Skåne till Lappland, Makadam, Göteborg/ Stockholm: 217-224.

(2016), «Spänningslitteratur för barn och vuxna. När målgrupper och genrer korsas i verkens paratexter», in Barnboken. Journal of Children's Literature Research, Vol. 39 2016: 1-24.

LANG, Maria (Dagmar Lange) (1949), Mördaren ljuger inte ensam, Norstedts, Stockholm.

LANGE, Dagmar (Maria Lang) (1985), Vem är du? Dagmar Lange eller Maria Lang, Norstedts, Stockholm.

LARSSON, Åsa (2003), Solstorm, Bonnier, Stockholm. (2008), Till dess din vrede upphör, Bonnier, Stockholm.

LUNDGREN, Lena and Lisbet Wikner (2014), Maria Lang. Vår första deckardrottning, Ordalaget bokförlag, Bromma.

LÄCKBERG, Camilla (2003), Isprinsessan, Warne, Sävedalen. 
(2005), Stenhuggaren, Forum, Stockholm. (2007), Tyskungen, Forum, Stockholm.

LÖVESTAM, Sara (2015), Sanning med modifikation, Piratförlaget, Stockholm. "Malin Persson Giolito», author information at the homepage for publishing house Wahlström \& Widstrand. www.wwd.se/forfattare/45770/malin-persson-giolito/, achieved 2018-11-30.

MARKLUND, Liza (1998), Sprängaren, Ordupplaget, Stockholm. co-authored with Maria Eriksson (1995), Gömda, Bonnier Alba, Stockholm. co-authored with Maria Eriksson (2004), Asyl, Piratförlaget, Stockholm.

MATZ, Kerstin (1997a), «Högklassig underhållning - skriven i den lättaste satiriska ton», in Jury 1997:2, 16-20. (1997b), «Den Rosenbladska mordhistorien!», in Jury 1997:2: 21-23.

NEIJ, Maria (2009), «Att titta ner i det svarta hålet. Inger Frimansson», in 13 svenska deckardamer, BTJ Förlag, Lund: 61-76.

NILSONNE, Åsa (1991), Tunnare än blod, Trevi, Stockholm.

OHLSSON, Kristina (2009), Askungar, Piratförlaget, Stockholm. (2010), Tusenskönor, Piratförlaget, Stockholm. (2014), Lotus blues, Piratförlaget, Stockholm. (2015), Mios blues, Piratförlaget, Stockholm. (2016), Sjuka själar, Piratförlaget, Stockholm.

PERSSON, Magnus (2002), Kampen om högt och lågt. Studier i den sena nittonhundratalsromanens förhållande till masskulturen och moderniteten, Brutus Östlings Bokförlag Symposion, Stockholm/Stehag.

PETERSON, Marie (2009), «Hålla huvudet kallt. Karin Alvtegen», in 13 svenska deckardamer, BTJ Förlag, Lund: 31-46.

PERSSON GIOLITO, Malin (2008), Dubbla slag, Piratförlaget, Stockholm. (2016), Störst av allt, Wahlström \& Widstrand, Stockholm.

POLONI, Helena (Ingegerd Stadener, 1956), Mord i barm, Stockholm.

ROGNEBY, Jenny (2014), Leona - tärningen är kastad, Wahlström \& Widstrand, Stockholm. Sara Lövestam's homepage: https://saralovestam.se/about/, achieved 2018-12-14.

SARENBRANT, Sofie (2010), Vecka 36, Damm, Malmö. (2012), Vila i frid, Damm, Malmö. (2013), Andra andningen, Damm, Stockholm. (2014), Visning pågår, Damm, Stockholm. (2016), Tiggaren, Bookmark, Stockholm. (2017), Bakom din rygg, Bookmark, Stockholm.

SARRIMO, Cristine (2000), När det personliga blev politiskt. 1970-talets kvinnliga bekännelse och självbiografi, Brutus Östlings bokförlag Symposion, Stockholm/Stehag.

SCHEPP, Emelie (2013), Märkta för livet, En \& Ett, Stavsjö. 
SJÖHOLM, Carina (2011), Litterära resor. Turism i spåren efter böcker, filmer och författare, Makadam, Göteborg/Stockholm.

STEN, Viveca (2008), I de lugnaste vatten, Forum, Stockholm.

STOUGAARD-NIELSEN, Jakob (2017), Scandinavian Crime Fiction, Bloomsbury, London.

SÖDERLUND, Maria (1997), «För het på gröten? Maria Lang och sexualiteten», in Jury 1997:4: 12-17.

TAPPER, Michael (2011), Snuten i skymningslandet. Svenska polisberättelser i roman och film 19652010, Nordic Academic Press, Lund diss.

THELANDER, Inga (årtal?), Blues för en blond dam, Ljus, Stockholm. (1959), Eldfågeln, Norstedts, Stockholm.

TORNBORG, Emma (2014), «Jämtland: Kroppens, politikens och minnets naturlandskap - Kerstin Ekman», in Kerstin Bergman (ed.), Deckarnas svenska landskap. Från Skåne till Lappland, Makadam, Göteborg/Stockholm.

TORNBORG, Katarina (2014), «Gotland: Den traditionstyngda och lockande ön - Anna Jansson», in Kerstin Bergman (ed.), Deckarnas svenska landskap. Från Skåne till Lappland, Makadam, Göteborg/Stockholm: 61-70.

TROSELL, Aino (1999), Ytspänning, Prisma, Stockholm.

TURSTEN, Helene (1998), Den krossade tanghästen, Anamma, Göteborg.

WEDDING, Gunilla (2009), «När tonårsmamman blev deckarhjälte. Helene Tursten», in 13 svenska deckardamer, BTJ Förlag, Lund: 219-237.

WENNSTAM, Katarina (2007), Smuts, Bonnier, Stockholm. (2008), Dödergök, Bonnier, Stockholm. (2010), Alfahannen, Bonnier, Stockholm. (2012), Svikaren, Bonnier, Stockholm.

Viveca Sten's homepage: https://www.vivecasten.se/viveca, achieved 2018-12-11.

WOPENKA, Johan (1997), «Ge oss en deckardam - skapad av en kvinna», Jury No. 3, 13-17. (2009), «Kvinnlig deckarhistoria, från 1800-talets mitt till 1900-talets slut», in 13 svenska deckardamer, BTJ Förlag, Lund: 7-30. 



\section{Autoras gregas de textos policiais}

Virginia Spyratou

Univ. Atenas

\section{Introdução}

A literatura policial da Grécia, à semelhança da de outros países, desenvolveu-se como uma árvore que vai dando frutos: autores, autoras, tendências, formas narrativas. As temáticas, as edições e o gosto dos leitores vão evoluindo à medida que a árvore cresce, alta e frondosa. Neste texto iremos apresentar a história das autoras de textos policiais, cujas obras constituem uma parte importante da história da literatura grega. A apresentação será organizada de acordo com três fases cronológicas, entre 1913 e 2017, ${ }^{1}$ tornando-se, desta forma, evidente quais os contextos que promoveram ou que, pelo contrário, atrasaram o desenvolvimento da literatura policial na Grécia.

É indiscutível que, nos últimos anos, este género literário se tornou extremamente apreciado pelo público, o que decorre não apenas do número de edições e dos números e factos relativos ao mercado livreiro, mas também da fundação, em 2010, do Clube Grego de Autores Policiais (ELSAL), bem como do lançamento, em 2016, da revista CLM (The Crimes and Letters Magazine), de vida infelizmente curta - foram pulicados apenas três fascículos, sendo a revista suspensa em 2018. Os editores da CLM criaram, então, em 2018, a revista POLAR com artigos e entrevistas sobre teoria da literatura policial. Há ainda a registar clubes de leitura, um pouco por todo o país, assim como bloggers que se ocupam exclusivamente de romances policiais. São ainda publicados em revistas literárias e jornais numerosos artigos sobre literatura policial, quer nacional quer estran-

\footnotetext{
${ }^{1}$ Segundo as categorias de Filippos Filippou na sua história da literatura policial na Grécia. (Filippou 2018).
} 
geira, e escrevem-se artigos científicos sobre o mesmo assunto. Prova desta alteração e da valorização da literatura policial é o facto de, nos últimos anos, se terem publicado livros e ensaios sobre Giannis Maris, repórter e autor, que foi o maior representante do género na Grécia entre 1953 e a sua morte em 1979, quando até há pouco tempo, era quase humilhante admitir em círculos intelectuais que se liam os seus livros (Kaisidou 2018). De assinalar é também que os investigadores Elisabeth Kotzia e Vaggelis Chatzivassiliou tenham incluído nas suas histórias da literatura um capítulo dedicado à literatura policial - até agora, nunca numa história da literatura grega se tinha mencionado a literatura policial (Filippou 2018b: 351). Finalmente, em 2018, foi, ainda, publicada a história da literatura policial grega, de Filippos Filippou.

Apesar de tudo, não pode esquecer-se que a bibliografia crítica sobre autores policiais é, ainda, muito limitada e que é especialmente difícil encontrar tais obras, não só em livrarias, porque muitas estão esgotadas, mas também nas bibliotecas, pelo que queremos deixar aqui um agradecimento muito especial aos seguintes escritores: Vassilis Danellis, presidente da ELSAL, pelo apoio que nos deu, Filippos Filippou pela partilha de informação importante e à escritora Hilda Papadimitriou, que, de bom grado e de forma muito interessante, respondeu às nossas perguntas.

\section{O início (1938-1981)}

A história dos romances policiais na Grécia está estreitamente ligada ao mundo das revistas. Trata-se de cadernos baratos de impressão fraca, mas muito apreciados pelo público, e que faziam parte da pulp fiction grega - a ideia para a sua organização veio do estrangeiro. Em 1935, Apostolos Maganaris e o editor Michalis Saliveros publicaram a revista Mascara com traduções de novelas estrangeiras, a que se juntaram outras revistas do mesmo tipo e com nomes sonantes como Aranha, Ass, Sphinx, Segredo, Mão Negra, Charada, e o seu sucesso foi irrefutável.

No início, traduziam-se histórias policiais estrangeiras famosas e desta forma se apresentaram ao público grego heróis como Sherlock Holmes e Hercule Poirot, cujas aventuras foram sendo alargadas, enriquecidas e reescritas por autores e autoras gregos. As temáticas e o estilo destes textos revelavam-se, assim, sob influência de Agatha Christie, Peter Cheney, Ian Fleming e de Georges Simenon. 
Nesta primeira fase da literatura policial na Grécia, mulheres como Georgia Deligianni, Irini Kalkani e Kalliopi Sfaellou também escreveram na Máscara (Filippou 2018b: 65). Na verdade, eram principalmente mulheres quem traduzia as histórias para as revistas (Fillipaios 2017).

A tradutora de histórias policiais mais ativa foi Tasso Kavvadia (1921-2010), atriz, jornalista, produtora de rádio e tradutora, mas foi Eleni Vlachou (19111955), editora, jornalista e, muito mais tarde, também, política, a primeira a escrever um romance policial, com o título 0 segredo da vida de Petros Verinis, que foi editado em 1938, em 38 episódios, no jornal Kathimerini. Filippou (Idem: 44) defende que este é o primeiro policial a ser escrito na Grécia, dado que o texto O crime de Psychiko (2014) de Pavlos Nirvanas (1866-1937), que era considerado o primeiro policial, é na verdade uma paródia. O romance, influenciado pela tradição literária de Agatha Christie, gira à volta dos segredos de uma família da grande burguesia em Psychiko, bairro rico de Atenas, depois do envenenamento do patriarca Petros Verinis.

Nos anos 50, depois do fim da Guerra Civil grega que sucedeu à Segunda Guerra Mundial, a Grécia caraterizava-se, primeiro, por um conservadorismo etnocêntrico que, enquanto ideologia política, influenciava a vida quotidiana e, segundo, pela aceitação do estilo de vida ocidental e das suas formas de entretenimento. Em especial a cultura americana teve uma grande influência em áreas como a literatura, as revistas, a música e o cinema. O resultado foi um cada vez maior número de romances policiais traduzidos ao longo dos anos 50 e, sobretudo, ao longo dos anos 60. Surgiram novas casas editoras, que, debatendo-se, embora, com graves problemas financeiros, anunciavam nos seus catálogos romances policiais (Fillipaios 2017), e eram cada vez mais os autores e autoras a escreverem histórias policiais com tramas interessantes, ainda que de ambições literárias diminutas (Tonnet 2014).

É Athina Kakouri (1928-) quem estabelece a ponte entre o ontem e o hoje na literatura policial de mulheres na Grécia. Nascida em Patras, viveu em Atenas durante a segunda Guerra Mundial e depois da guerra trabalhou quer em agências marítimas, quer como repórter no jornal Tachydromos; escreveu textos para programas de rádio e traduziu obras literárias e históricas. Mais tarde, estabeleceu-se em Viena, onde estudou história moderna, vindo a revelar-se como escritora em 1950, com a publicação de uma série de folhetins sobre uma viagem ao Médio Oriente. Ao mesmo tempo, traduzia do inglês e do francês, romances e livros científicos de história para as casas editoras Papyros e Pechlivanidis. Em 1959 
literatura da metrópole, de ritmo acelerado. Os autores e autoras desse período apresentam ao leitor situações e condições que conheciam na sua vida quotidiana (Kontopidou 2009: 56). Até esta altura, as histórias policiais eram publicadas em revistas ou em edições muito baratas, que se podiam comprar nos quiosques. Agora, editoras como a Pechlivanidis, a Galaxias, a Lychnari e a Papyros Press tentam dignificar o romance policial: melhora a qualidade das edições, e os policiais, abandonada a classificação de literatura menor, passam a poder comprar-se em livrarias de renome.

Registam-se neste período três alterações de relevo: primeiro, a literatura policial é considerada como literatura simultaneamente popular e séria. Segundo, os heróis e a trama dos romances policiais gregos subtraem-se à influência dos Estados Unidos, da Inglaterra ou da França, adaptando-se a sua conceção, os heróis, o estilo e a linguagem mais à realidade grega. Um terceiro ponto a referir é o facto de antes dos anos 90 a maior parte dos autores policiais - tanto homens como mulheres - serem repórteres que publicavam artigos simples e medianos para o público em geral, enquanto a nova geração se rege por uma estética literariamente mais ambiciosa (Tonnet 2014).

Na segunda fase, são um total de oito as autoras que escrevem histórias policiais. No início do nosso século, Athina Kakouri dá à estampa uma coletânea de contos com o título Crime da moda (2003), Titina Danelli publica em 1981, em conjunto com o conhecido escritor Manos Kontoleon, o romance Um mais um é igual a tantos quantos tu quiseres, no qual surgem o detetive privado Kostas Vasiliou e a jornalista Eugenia Eugenikou, que virá a protagonizar, também, livros posteriores de Danelli. O romance começa com o homicídio de um ministro, tecendo-se alguns comentários políticos com alusões à ditadura grega.

A escritora Neni Efthimiadi (1946-2008) está representada com cinco publicações: em 1983 publica Dias sem ruído, em que os heróis se envolvem em questões de tráfico de armas e ataques terroristas. Seguem-se, em 1988, o romance A cor do futuro, em 1990, o volume Morte suave e, em 1993, o romance Os cidadãos do silêncio, que constitui um diálogo divertido e ao mesmo tempo subversivo entre cidadãos e terroristas. No ano 2000, foi publicado o romance Os aventureiros, que versa, também ele, sobre organizações terroristas e ataques bombistas, ainda que o estilo não seja o dos policiais clássicos (Filippou 2018b: 326).

Chrysa Spyropoulou (1957-) é, também ela, presença assídua na cena da literatura policial. Edita, em 1998, Nevoeiro no lago, cujos heróis são o polícia Iliou e a sua ajudante, a menina Georgiou. Trata-se da história de um desaparecimento 
que, apesar de começar como um texto policial, se revela, no fim, um relato de problemas psicológicos. Em 2000 é dado à estampa o seu segundo romance, com o título Mascaras na sombra (2000).

Myrto Tapanli publica dois livros: o conto Correspondências, no ano de 1994, e, em 2000, o romance Pralinas de Bruxelas, cuja ação gira à volta de um autor policial que confunde realidade e ficção.

Por sua vez, Marlena Politopoulou (1950-) publica em 1999 o livro O Senhor Marios arrependeu-se tarde, tendo como protagonista uma figura peculiar: o arquiteto e retratista forense Pavlos G., que trabalha com o polícia Periklis Jiantzoglou, cujas investigações psicológicas se mostram algo duvidosas (Tonnet 2014). A história desenvolve-se na ilha de Andros, onde intelectuais vivem lado a lado com novos ricos e lavradores.

Em 1999, surge o romance 0 segredo das rochas, de Popi Magoula-Gaitanou e, em 2000, o livro de Maria Chatzibajanteri O tempora, o mores ou o que viu a gata branca.

\section{O boom (2001-2017)}

A tendência para uma literatura realista e de cariz social que marcou a segunda fase continua presente, também, na terceira. Os autores encontram inspiração para os seus temas nas notícias, na imprensa, na vida dura do povo, em atividades ilegais das celebridades. Os heróis e heroínas são apreciados pela autenticidade do seu carácter e por se assemelharem a pessoas reais. É também relevante a constatação de que existe uma mudança no que diz respeito ao crime. Este já não é próprio do marginal que foi injustiçado na esfera pessoal ou social. O crime deixa o âmbito do privado, e prende-se agora com diferentes aspetos sociais e políticos (Kontopidou 2009: 72) e muitos dos melhores textos policiais apontam para importantes temas sócio-históricos. Neste contexto, as referências a circunstâncias históricas constituem, frequentemente, crítica social.

A terceira fase caracteriza-se, antes do mais, por uma explosão, já que são cerca de oitenta as autoras que publicam ao longo destes anos. Há ainda dois outros fenómenos dignos de nota: primeiro, o aparecimento de literatura policial infantil e juvenil e, segundo, a publicação de coleções de histórias policiais que integram obras de um grande número de autoras conhecidas.

Hilda Papadimitriou, uma das mais populares autoras policiais dos últimos anos, afirma a propósito do grande acréscimo de literatura policial regis- 
tado na Grécia desde 2001 que o público passou a apreciar este género graças ao trabalho sistemático de muitas casas editoras, como Agra, Polis, Metechmio e Kedros. Depois da explosão do romance noir escandinavo, era a altura perfeita para os autores gregos escreverem e publicarem policiais, dado que a procura era enorme. Tiveram, também, um papel importante as séries policiais da televisão, muito populares na Grécia. ${ }^{2}$

O registo que se segue não é exaustivo; limitámo-nos às autoras com presença assídua no mundo dos policiais e àquelas cujas obras podem ser consideradas inovadoras ou de interesse especial: Athina Kakouri publica, em 2001, a coletânea de contos A cabeça cortada e o romance Os jardins do diabo; Chrysa Spyropoulou, em 2004, o romance Um jogo inocente, que se ocupa da ligação entre homicídio e redes sociais e, dois anos depois, Sem rastro, romance que tem como tema os resíduos radioativos. Em 2009, é dado à estampa o policial Kamio, de Ioanna Tobrou (1953-), em que têm um papel-chave o estado psicológico dos heróis assim como as suas histórias traumáticas.

Quanto a Christiana Sourvinou-Inwood (1945-2007), ela combina as histórias policiais com o romance histórico: Um homicídio muito clássico é publicado em 2003, sob o pseudónimo de Christiana Elfwood. A história desenrola-se na Antiguidade, em Esparta e Brauro [Vravrona], na terra sagrada da deusa Artemisa. O romance, bem estruturado, descreve de forma vibrante a vida na Grécia antiga. A autora estudou em Atenas e em Oxford e lecionou arqueologia, literatura antiga, religião e mitologia gregas, tendo publicado vários livros e artigos sobre diferentes aspetos da cultura da Antiguidade. Por sua vez, Mimi Filippidi-Theochari refere-se nos seus romances Águas calmas (2009) e 0 atentado (2016) à mais recente história da Grécia dos anos entre as guerras gregas (1923-1940).

Em 2002, Afroditi Koukoutsaki (1950-), professora de sociologia na Universidade Panteion, publica Os equilibristas. No final dos anos 70, um grupo de estudantes gregos busca em Roma a sua identidade política, no contexto da esquerda extraparlamentar. Passados vinte anos, voltam a encontrar-se em Atenas, a propósito de uma morte que ninguém sabe se foi resultado de um assassinato ou suicídio. Tentam desvendar o mistério da morte e tornam-se ao mesmo tempo investigadores e investigados da sua própria verdade.

Em 2003 é editado o romance policial Assunto de família, de Kaiti Piperopoulou, cuja heroína, Erika, pertenceu no passado ao grupo terrorista Baader-

\footnotetext{
${ }^{2}$ Hilda Papadimitriou respondeu eletronicamente às nossas perguntas em Julho de 2018.
} 
-Meinhof. É de referir, também, o livro de Efi Nikoloudi Playing Possum, uma comédia policial vinda a lume em 2015.

Em 2007, surge o romance Gutter, de Dorina Papaliou, que nasceu em Atenas, estudou história e antropologia social em Inglaterra e escreveu também livros infantis, além de outro romance. A palavra inglesa «gutter» é não só utilizada pelos ilustradores de banda desenhada para designar o espaço em branco entre dois desenhos, como significa também sarjeta, ou o mundo do crime e dos criminosos. O romance desenvolve-se neste contexto de uma forma muito interessante, dado que a autora integra estes dois campos semânticos de forma relacional na ação. O herói é um aluno do último ano do ensino secundário que quer ser ilustrador profissional de banda desenhada. Os seus desenhos ajudam a desvendar o crime de uma empresa farmacêutica, que levava a cabo experiências sem autorização das suas cobaias humanas, toxicodependentes sem ligação às suas famílias. Assim, quando as experiências corriam mal e os levavam à morte, esta não era investigada. Por um acaso, o ilustrador estava presente quando o irmão de uma das vítimas é raptado e desenhou-o, tanto a ele como aos criminosos. Apesar do risco que corre, está determinado a desvendar o mistério.

Uma autora que já antes de 2001 se dedicava à escrita de policiais é Titina Danelli. Nascida em Atenas, estudou Românicas em Nápoles e Roma e também, tradução. Trabalhou como jornalista em diversas revistas e jornais e colabora, desde 1985, no jornal de esquerda Rizospastis, tendo escrito numerosos guiões para programas de televisão e dobrado múltiplos filmes. Nas suas obras, articula política e uma boa história policial, criando uma literatura de matriz sociopolítica livre de estereótipos fáceis. Os seus enredos baseiam-se em relações complicadas entre vítimas e criminosos, em manifestações de poder de orientação oposta, que exigem ocultação ou esclarecimento e em que a moral, a política e a história têm um papel determinante.

No livro de Danelli 0 jogo do juiz, editado em 2002, o comandante geral da polícia Aggelos Vlachos e a jornalista Eugenia Eugenikou encontram-se na aldeia idílica Milies de Pilion. É noite de Natal e, na mesma aldeia, o reformado Michalis Oikonomou recebe os amigos: o grande empresário Petros Sarris, a mulher Anna, e a bela Eleni Petridi, sua antiga amante, bem como o conhecido ator Ilias Galatis. Para passar o tempo, jogam o «jogo do juiz», um jogo de sociedade, no qual alguém é supostamente assassinado e o juiz tenta, então, descobrir o assassino. Neste caso, o homicídio acontece de verdade. O livro revela-se escrito de forma magistral e a narrativa brilhante contribui para uma leitura muito agra- 
dável. Um ano depois, Danelli publica o romance Ipso facto em conjunto com Thanasis Balodimas e, em 2004, A quarta mulher. Em ambos os textos aparecem os mesmos protagonistas famosos, o comandante geral da polícia Aggelos Vlachos e a jornalista Eugenia Eugenikou. No primeiro romance, os dois juntam forças para esclarecer o homicídio de uma pianista mundialmente conhecida, que abalou Atenas. No segundo, investigam o crime misterioso que a relação do «grandioso homenzinho» Leon com a sua quarta mulher esconde. Em 2007, Danelli publica em colaboração com Thanasis Paparigas o romance 0 major, uma história passada na Atenas dos anos 80, que trata um jogo de corrupção e poder no contexto da Guerra Fria.

O livro Os quatro tacos de golf é publicado em 2009. O espaço literário é, neste caso, Atenas, e tanto as altas esferas da polícia grega como a polícia secreta britânica estão envolvidas na história. Um agente secreto britânico segue a pista do homicídio de uma pessoa da sua família. O seu caminho da Namíbia para a Grécia cruza-se com o do general Vlachos e da jornalista Eugenia Eugenikou. A nível cronológico, a história passa-se em dezembro de 2008 e baseia-se num facto verídico, ocorrido na Grécia no ano anterior ao da publicação do livro. A 6 de dezembro de 2008, Alexandros Grigoropoulos, de quinze anos, foi morto por um agente da polícia, facto que chocou não só Atenas, mas toda a Grécia. Ao assassinato seguiram-se motins que se estenderam por vários dias. Este acontecimento real foi ligeiramente alterado no livro: o rapaz é mais velho e não morre, antes se encontra no hospital, ferido com gravidade. Os motins que se seguiram ao acontecimento real, assim como a crítica feroz à polícia são parte integrante do romance. Os agentes policiais no livro envergonham-se da sua atuação, muitos até da própria profissão. Também nesta obra a narração é sublime. Vlachos e Eugenikou são mortos no fim do livro, às mãos do mesmo assassino que fora responsável pelas provocações em Atenas, constituindo a própria morte dos protagonistas, em si mesma, pela sua forma inusitada, uma inovação.

Nascida em Atenas em 1955, Elena Akrita colaborou como jornalista na revista Tachydromos e no jornal To Vima, Ethnos, Ta Ne e em vários programas de rádio, tendo-se tornado conhecida e apreciada especialmente devido aos seus folhetins e livros, dos quais os últimos dois são romances policiais. Em 2015, publica Homicídio cinco estrelas, que trata o assassínio de um rico proprietário de hotéis, e, em 2017, o romance 0 mistério do edifício azul, que tem como cenário o famoso prédio azul em Exarchia, um espaço da cena underground de Atenas. Note- 
-se que o edifício azul foi construído pelo arquiteto Kyriakos Panajiotakos em 1932-1933 e é um dos mais antigos e bonitos prédios de Atenas.

No caso da obra Homicídio cinco estrelas trata-se de um policial clássico: o rico empresário do ramo turístico Yiannos Aslanoglou organiza, como todos os anos no mesmo dia, uma festa de Natal em sua casa, em Filothei, uma zona rica de Atenas, durante a qual, nesse ano, é encontrado morto no seu quarto, por trás de uma porta fechada à chave por dentro. A sua filha e a amiga, a jornalista Elsinori Chatzi, tentam descobrir se se tratou de um homicídio, de um acidente ou de um problema de saúde. Durante o processo vêm a descobrir-se segredos da melhor sociedade, mentiras, heranças e chantagens, que a jovem repórter Elsinori Chatzi desvenda no final com a ajuda de Andreas, o motorista da família. A linguagem da narrativa é simples, quase próxima da oralidade, como a de um guião. A trama assemelha-se, igualmente, à de um filme e é trabalhada de forma tão perfeita que nenhuma questão fica em aberto, tanto no que toca à relação entre as personagens como no que respeita às causas das suas ações.

No seu segundo caso policial, 0 mistério do edifício azul, a repórter Elsinori Chatzi tem já uma vida profissional bem melhor, devido ao sucesso que alcançou ao desvendar o homicídio de Aslanoglou (no primeiro policial de Akrita). Tem, agora, uma relação erótica com Andreas, e de novo precisará da sua ajuda para desvendar mais dois assassínios. Muito embora Elsinori desempenhe um papel mais destacado e Andreas ocupe um lugar secundário, a trama tem muitas parecenças com a do primeiro livro: Elsinori investiga a vida de um político famoso para estabelecer uma ligação entre um homicídio ocorrido nos anos 70 e o homicídio presente, enquanto uma casa em Kifissia, outra zona rica de Atenas, é relacionada com o decadente edifício azul do centro da cidade

A ligação à história recente da Grécia é evidente. O primeiro homicídio ocorre em 1973 na Escola Politécnica, no dia em que o regime ditatorial mandou os tanques avançar sobre os estudantes. Há, também, referências à crise económica grega no presente, à mudança de governo de 2015, aos motins dos grupos anarquistas em Exarchia. No segundo livro, a narrativa tem um carácter menos folhetinesco, apesar de a perspetiva ser, ainda, próxima da de um produtor cinematográfico. Estes elementos narrativos dos seus livros têm, talvez, a sua origem na influência mútua entre livros e séries de televisão, amplamente disseminadas nos últimos anos.

Eri Ritsou (1955-) nasceu em Vathi, na ilha de Samos. É filha de Garyfalia Georgiadou e do conhecido poeta Yiannis Ritsos. Estudou Anglística e trabalhou 
no Banco Nacional da Grécia e escreveu livros infantis e dois romances antes de publicar os seus dois textos policiais: 0 morto foi assassinado, de 2016, cuja protagonista, a agente da polícia Maria Georgiou, também aparece no seu segundo policial, publicado em 2017, com o título Há algo pendurado lá em cima. A ação é interessante, embora sem grandes surpresas, o ritmo é acelerado, os heróis têm medos e preocupações pessoais. O lugar da ação é, em ambos os casos, a ilha de Samos: o leitor entra, assim, em contacto com a sociedade da ilha, com a mentalidade dos seus habitantes, as leis não escritas, o pequeno mundo da ilha, o aborrecimento, a bisbilhotice.

No primeiro livro, 0 morto foi assassinado, a jovem polícia Maria Georgiou volta, por razões pessoais, à ilha onde tinha nascido, e onde tem um mistério para resolver, cuja complexidade se adensa gradualmente. Na floresta é descoberto o cadáver de um homem que esconde num dos bolsos um bilhete dizendo «Assim morrem os traidores» e no outro bolso a impressão de um email, onde se pode ler «Se não apareceres, mato-me»: no peito foi-lhe talhada uma cruz gamada. Maria Georgiou investiga o crime com ajuda masculina, mas não sob orientação masculina, e decide conscientemente não levar o culpado a tribunal, e isto por razões políticas. A vítima era um fascista, que abusava sexualmente de alunas da escola, e o culpado um médico prestável, para quem o fascismo é a fonte de todos os males. Apesar de o romance não encontrar uma solução tradicional, há uma outra forma de catarse: não pelo castigo do culpado, mas antes por, do ponto de vista do médico (e também da agente Geogiou), ter sido feita justiça aos mortos do passado que tinham sido eliminados por causa da sua ideologia de esquerda.

No segundo livro de Ritsou, Há algo pendurado lá em cima, a agente da polícia Maria Georgiou ocupa-se de um caso complicado. O cadáver de uma mulher está pendurado num poste telefónico na ilha de Samos. Embora os primeiros indícios apontem para que se trata de suicídio, a agente decide continuar a investigar. Há poucas pistas que possam ser seguidas, muitos suspeitos, e Georgiou percebe que também ela está pessoalmente envolvida na história. Depois de desvendado o assassínio, a agente decide, como mãe solteira, mudar de carreira e tornar-se jurista. Os livros têm ambos conotações políticas, comentários sobre a crise social e económica na Grécia e sobre o drama dos migrantes, e também comentários azedos ao governo grego pós 2015.

Segue-se Marlena Politopoulou (1950), originária de Atenas, em cuja universidade estudou ciência política, tendo trabalhado ao longo de vinte anos como 
jornalista em revistas e na rádio, lecionado na faculdade de comunicação e mass media da universidade de Atenas e na universidade Pantheion, e publicado novelas e romances.

Em 1999 vem a lume o seu primeiro policial, com o título O Senhor Marios arrependeu-se tarde e, em 2005, Doze deuses, três homicídios. No romance policial A memória de Polaroid, publicado no ano 2009, é tematizada a guerra civil grega do final dos anos de 1940. Também o romance A Penélope dos comboios, de 2015, se passa em tempos difíceis: durante a guerra civil e depois, nos anos 50 e 60, quando os gregos emigram para o estrangeiro de forma massiva.

O Senhor Marios arrependeu-se tarde reúne todos os elementos de um bom policial. O local do crime é «fechado», trata-se da ilha Andros, e esta confere à história o verdeiro mistério: mar agreste, ruas estreitas, o monte na noite de lua cheia. As pessoas envolvidas na história não são apenas camponeses, mas também poetas e pensadores que fundaram em Andros uma pequena comunidade. Têm em comum o facto de viverem numa pequena aldeia com vista sobre o mar Egeu, cheia de ciprestes e limoeiros. Um cenário idílico, que esconde grandes segredos e antagonismos nas relações humanas. O ilustrador Paul G. e o agente da polícia Yiatzoglou seguem as pistas do Senhor Marios, que foi encontrado morto junto a uma nascente empedrada, de fato e chapéu de feltro, e ficam a saber de muitos segredos sobre as relações entre os moradores: desvendá-los lança uma nova luz sobre o presente e sobre o passado.

O livro Doze deuses, três homicídios é, também, um policial clássico. O agente da polícia Periklis Yiatzoglou, um agente de recorte estereotipado e o seu amigo, detetive e ilustrador forense Paul G. (Georgoulas) trabalham em conjunto para desvendar o assassínio de uma jornalista num salão de beleza em Loutraki, uma pequena cidade perto de Atenas. Uma ação interessante, personagens realistas, surpresas e ritmo acelerado dominam um policial cuja solução é encontrada no templo Heraion, erigido em honra da deusa Hera e situado em Loutraki. O ilustrador policial que desvenda os crimes é um homem arrebatado, para quem o trabalho se sobrepõe à vida pessoal.

No seu livro A Penélope dos comboios, Politopoulou liga o drama dos migrantes na Grécia de hoje ao drama dos migrantes gregos na Alemanha dos anos 60. Também desta vez o comissário Yiatzoglou trabalha com Paul G.. Este é filho de um conhecido agente da polícia que ao morrer lhe deixou uma mala cheia de casos por resolver, que o filho tenta agora desvendar. Na verdade, Paul G. é, como ele próprio diz, um arquiteto com «genes de detetive», e, após vários anos como 
Ao grupo de colaboradores de Nikolopoulos pertence, também, uma mulher simpática e dinâmica que, mais tarde, se tornará mãe solteira e que assume o lugar de Nikolopoulos depois do afastamento deste. Ainda que nos três livros a sua presença não seja central, é importante que ela tenha um lugar na narrativa. No último livro, entra para o grupo um homossexual, que apresenta o seu marido ao grupo e é bem-recebido por todos e aceite como um igual.

A ação dos romances é rápida, fluida, interessante, trabalhada de forma brilhante. A narração é notável e é acompanhada por música: são referidos versos conhecidos, assim como canções, tanto gregas como estrangeiras, que a maior parte dos leitores já alguma vez cantou. As personagens são sensíveis, românticas, apaixonadas, muitas vezes sem uma saída possível. Vivem num mundo onde a música não é uma questão secundária, um acompanhamento das suas atividades, é, antes, um elemento nuclear das suas vidas. Passam o tempo em lojas de discos de vinil, em concertos, bares e estações de rádio. E matam ou são mortas por causa da sua paixão pela música. Os livros têm uma estreita ligação com a sociedade grega e a crise económica é abordada, sobretudo no terceiro livro. Todos estes elementos conferem aos textos de Papadimitriou uma visão inovadora num espaço literário que pode ser ainda muito conservador.

Em conversa connosco, ${ }^{3}$ a escritora admitiu nunca, nem em criança, ter considerado a literatura policial como inferior. Escolheu os policiais de forma consciente, não só porque a ideologia de esquerda através de Antonio Gramci, Bertolt Brecht e Borges lhe deram argumentos para tal, mas, também, por estar fascinada pela estrutura rígida dos policiais, assim como pelo caminho que o detetive e/ou o herói tem a percorrer para desvendar o crime e reestabelecer a moral. Justiça e moral são, para a autora, os elementos mais importantes da civilização humana e a catarse, que se segue ao desvendar do mistério, dá-lhe a ilusão de repor a ordem no nosso mundo caótico.

\section{Epílogo}

Neste epílogo iremos analisar se é lícito afirmar-se que a obra das autoras policiais da Grécia apresenta características comuns tais que lhe permitam estabelecer-se como uma categoria do romance negro mediterrânico. Thanasis Minas

\footnotetext{
${ }^{3}$ Hilda Papadimitriou respondeu eletronicamente às nossas perguntas em Julho de 2018.
} 
(Minas 2016) refere que o conceito de «romance policial mediterrânico» foi introduzido na Grécia por volta de 2007, por escritores como Petros Markaris. O objetivo era a distinção entre a escrita literária das narrativas do Sul e os thrillers escandinavos (por exemplo de Jo Nesbø), tendo em vista evidenciar as dimensões sociais dos romances do Sul. No entanto, Minas não fala de uma escola do romance negro mediterrânico em oposição aos romances escandinavos, que, esses sim, formam uma escola, mas antes com um sentido pejorativo. $O$ autor defende que, com exceção de Henning Mankell e Gunnar Staalesen, os romances escandinavos se parecem muito uns com os outros: têm características estandardizadas, como a ausência de dimensão literária, o ritmo muito acelerado, a narrativa e a trama de forma simples que se assemelham a sitcoms televisivas.

No espaço mediterrânico, Minas não encontra, contudo, nem um estilo uniforme nem técnicas narrativas comuns que possam considerar-se canonizadas. O que existe são temas próximos, que têm a sua origem em experiências históricas paralelas. Os topoi temáticos são, em muitos casos, comuns: guerra civil, período de transição entre a ditadura e a democracia, emigração e imigração, questões de identidade cultural, as desigualdades socias intensas. Todavia, a forma como são desenvolvidos estes temas é diferente, ainda que se trate de escritores do mesmo país. Por isso mesmo, Minas utiliza o conceito de «romance negro mediterrânico» apenas no contexto da heterogeneidade, da diversidade e da polifonia.

Vassilis Danellis e Yiannis Ragos, editores da coleção com o título BalkaNoir (Danellis/Ragos 2018a), em que são apresentados ao público grego escritores dos países balcânicos, defendem, no mesmo sentido, que as obras dos escritores balcânicos não seguem nem uma unidade narrativa e nem uma forma fixa. Daí não se poder falar de uma escola do romance negro balcânico (Danellis/Ragos 2018b: 25).

Filippos Filippou (Filippou 2018a) vai mais longe:é de opinião que o romance policial europeu é baseado na obra de Jean-Patrick Manchette, que em França é designado como «neo-polar». Através do policial, Manchette descreveu histórica e socialmente a lei e a ordem num determinado momento temporal e histórico. A literatura policial devia servir, neste sentido, para denunciar a corrupção policial, bem como os motivos sociais que levam as pessoas a cometer crimes.

Filippou considera que este ramo do romance negro foi preferido por escritores nos países mediterrânicos e que se desenvolveu fora do enquadramento dos romances americanos hard-boiled (Hammet, Chandler) ou de mistérios 
whodunit(Doyle, Christie), não tendo nada a ver com os policiais dos países escandinavos, em que os crimes são cometidos por doentes mentais (Jo Nesbø, Camilla Läckberg). A designação «romance negro mediterrânico» têm causas típicas, que estão relacionadas com os países onde se podem encontrar estes romances (França, Espanha, Itália, Grécia e Turquia). Os autores interessam-se mais pelas condições sociais em que os crimes são cometidos e menos pelos criminosos. Não é por acaso que a literatura policial mediterrânica é escrita, em muitos casos, por autores de esquerda. Tem algo em comum com a literatura policial americana de James Elroy e com a latino-americana de Paco Ignacio Taibo II, por exemplo.

Segundo Filippou, o grande êxito dos policiais prende-se, assim, com o facto de estes terem ocupado o lugar da literatura de intervenção social, hoje menos em voga. Também as temáticas tratadas corroboram esta teoria: globalização, escândalos económicos, migração, racismo, corrupção do estado, poluição, relações de poder e crime organizado, história. Na opinião de Filippou, o policial mediterrânico moderno utiliza o mistério, o drama, a agonia, e também a paixão para estimular a consciência do leitor e abrir brechas na sua indiferença.

Os autores de textos policiais gregos, tanto homens como mulheres, são, neste sentido, influenciados pelo romance negro mediterrânico, visto que nas suas obras as condições sociais e políticas, têm, muitas vezes, um papel central. Depois da ditadura, ou seja, depois de 1973, os intelectuais gregos foram influenciados pela cultura francesa do Maio de 68 e têm, por isso, grande apreço pelos policiais franceses. De qualquer forma, é importante a grande ligação entre realidade e história gregas. A maior parte dos livros não são escritos num vazio espácio-temporal, têm, antes, bases, âncoras e raízes nos contextos gregos, tanto no que concerne às personagens como ao recorte da narrativa. A Segunda Guerra Mundial e a Guerra Civil grega são temas frequentes, já que enquanto passado coletivo influenciam a realidade grega atual, assim como a ditadura grega (19671973), o terrorismo, a crise económica e as alterações políticas dos últimos anos.

Em algumas obras (como em A Frequência da morte, de Papadimitriou ou em Os quatro tacos de golf, de Danelli) é comum a polícia não ser glorificada, antes ser duramente criticada. Os heróis de Papadimitriou e Ritsou abandonam, no final, a sua carreira policial e, em Danelli, o mundo da polícia é turvo e traiçoeiro. A receita não parece ser a dos policiais hard-boiled, mas antes aquilo a que os anglo-saxónicos chamam humanistic crime fiction (Papadimitriou 2018: 18). É de referir que, em alguns caso,s existe a tentativa de evitar modelos sexistas e clichés racistas, mas apenas algumas autoras têm a coragem de fazer uma des- 
construção total. Kaisidou (Kaisidou 2014) nota no seu artigo sobre literatura policial na Grécia, o qual não se limita a referir autoras mulheres: «(...) there is an absence of alternative detection, namely the use of a culturally non-conforming character in the position of the detective, which could subvert the normative role of the white, heterosexual male investigator».

Pode, talvez, argumentar-se que o romance policial, na sua rigidez formal, não permite desconstruções. Apesar disso, a quebra dos estereótipos existe desde os anos 80, quando Sara Paretsky, Sue Grafton ou Patricia Cornwell criaram heroínas que eram detetives e tinham características pouco convencionais: eram separadas, solteiras, oriundas de zonas problemáticas, tinham ligações ao mundo da anti-cultura, eram focadas na sua carreira (Papadimitriou 2018: 18).

Acresce ainda que, se o romance policial funcionar como espelho da sociedade que descreve, então não deve ser um espelho deformador, de maneira que os heróis não sejam caricaturas no que toca ao género ou ao estatuto social. O pós-moderno tem, de qualquer forma, em si, os conceitos de fluido, do eu em constante mudança, das múltiplas formas de determinação sexual, o distanciamento irónico face à estabilidade e à imutabilidade (Giannaki 2018: 20).

Na verdade, algumas autoras gregas como Papadimitriou, Ritsou, Akrita e Danelli utilizam mulheres como personagens importantes ou protagonistas na resolução dos casos, ou, também, homossexuais que gozam na polícia de uma posição idêntica à de colegas heterossexuais (em A Frequência da morte de Papadimitriou). Reconhece-se, assim, uma tentativa de quebrar estereótipos, ainda que, em outros casos, como em Spyropoulou, Kakouri ou Politopoulou, não se identifique nenhum corte com o mundo marcadamente masculino do romance negro. Sobretudo em Spyropoulou e Kakouri, os heróis tornam-se, muitas vezes, servidores da trama, o que intensifica estereótipos sociais e de género.

Também em Politopoulou, que tem uma temática social, a imagem da mulher é desvalorizada, pela apresentação que dela é feita pelo herói Paul G. Na sua perspetiva, as mulheres são artigos decorativos, que lhe embelezam a vida momentaneamente e que são postas de parte quando precisa de trabalhar. No livro Doze deuses, três homicídios o primeiro assassínio encerra, desde logo, algo de degradante para as mulheres, já que se trata de uma jornalista que é morta enquanto se encontrava dentro de uma das «máquinas de beleza». Da mesma forma, a agente policial Iro Mitilinaiou, que ajuda os dois protagonistas, limita-se ao papel da ajudante, apesar de ser sobre-qualificada. Acresce ainda que, correspondendo ao estereótipo, tem medo da condução demasiadamente rápida de 
Paul G. Este continua a agir de forma sexista no policial A Penélope dos comboios. Por exemplo, quando se fere na perna, todos os dias aparecem as suas antigas amantes para tratar dele e para o satisfazer sexualmente.

A escritora Miranda Vatikioti chama a atenção para uma outra questão importante: partindo-se do princípio de que que a literatura policial é, muitas vezes, uma ferramenta fiável de análises sociológicas, então devemos perguntar-nos se as representações de género são um retrato da realidade social, uma previsão de futuro ou, pelo contrário, a imagem de um desejo. De facto, os gays ou trans representados em policiais modernos gregos estão de tal forma livres de estereótipos que quase não são reconhecíveis (Vatikioti 2018: 23). O colega gay de Nikolopoulos, no livro de Papadimitriou, não tem qualquer outra característica para além do seu género, não é perseguido por estereótipos, como se a posição dos homossexuais dentro da instituição profundamente patriarcal que é a polícia grega fosse totalmente equitativa e a ausência de discriminação já fosse uma realidade.

Também no que se refere ao estilo dos autores policiais gregos, é muito difícil estabelecer semelhanças. Naturalmente que vai longe o tempo em que uma forma narrativa mediana ou mesmo má era suficiente para escrever um romance policial: pode dizer-se que os livros das autoras são eficientes em termos linguísticos e literários, dependendo naturalmente do dom de cada uma delas. De qualquer forma, é digna de análise a hipótese de trabalho que sustenta que neste momento é mais provável que qualquer quebra das normas, qualquer alteração na forma estereotipado dos policiais na Grécia provenha de uma autora mulher.

Tradução de Benedita Soares

\section{Bibliografia}

\section{Textos literários}

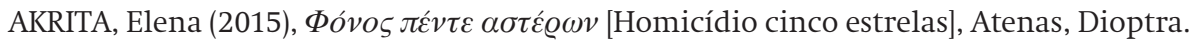

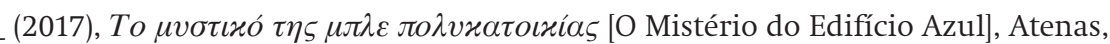
Dioptra.

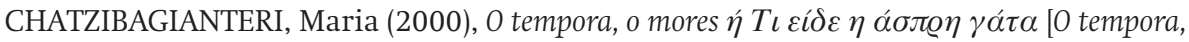
o mores ou o que viu a gata branca], Atenas, Odysseas.

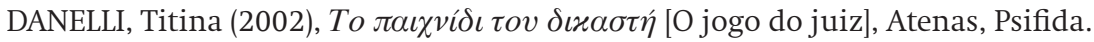




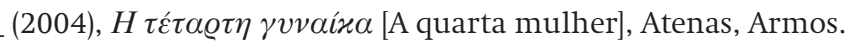

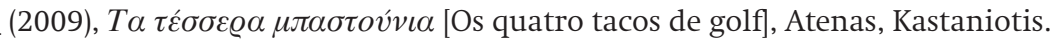

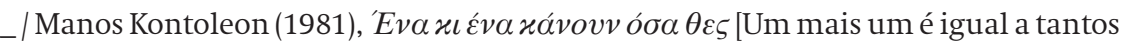
quantos tu quiseres], Atenas, Kastaniotis

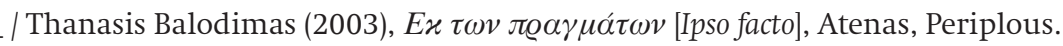

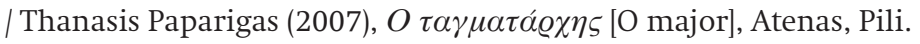

DANELLIS, Vassilis / Yiannis Ragkos (Hg.) (2018a), BalkaNoir, Atenas, Kastaniotis.

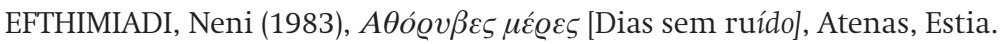

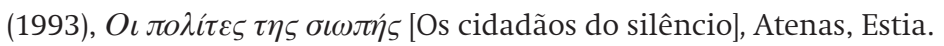

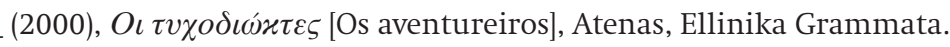

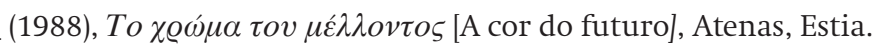

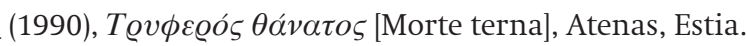

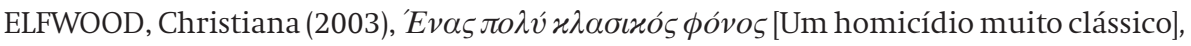
Trans. El. Kapetanaki, Atenas, Livanis.

FILIPPIDI, Mimi (2009), 'H

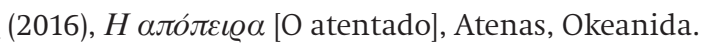

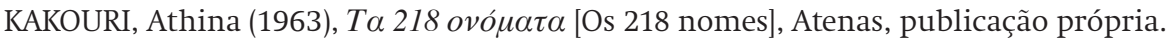

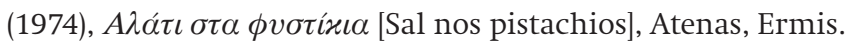
(2001a), $H \varkappa о \mu \mu \varepsilon ́ v \eta \varkappa \varepsilon \phi \alpha \lambda \eta ́$ [A cabeça cortada], Atenas, Estia.

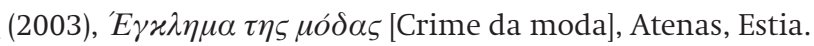

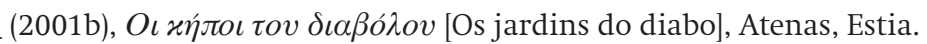

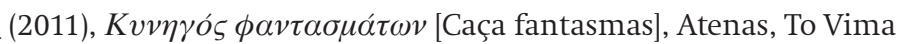

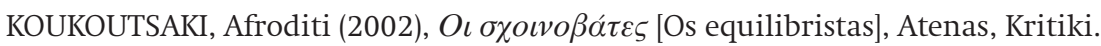

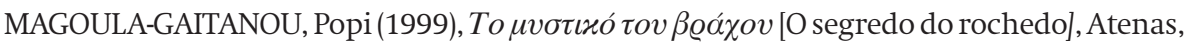
Agyra.

NIKOLOUDI, Efi (2015), Playing Possum, Atenas, Kyfanda.

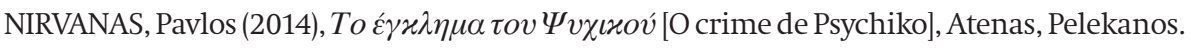

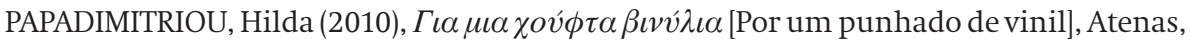
Metechmio.

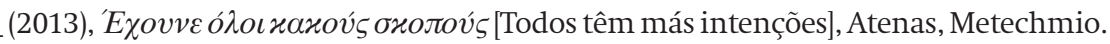

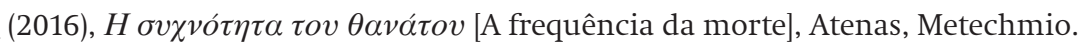

PAPALIOU, Dorina (2007), Гxá $\varepsilon \varrho$ [Gutter], Atenas, Kedros.

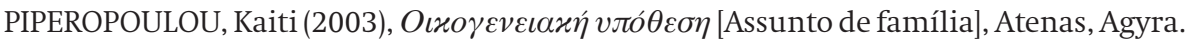

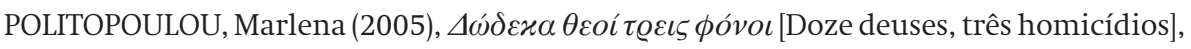
Atenas, Kedros.

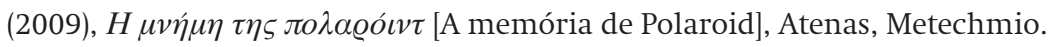

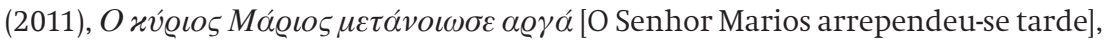
Atenas, Metechmio.

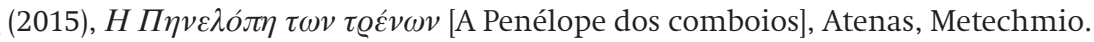




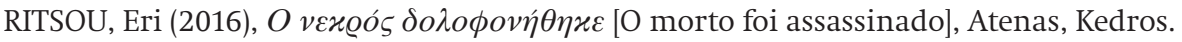

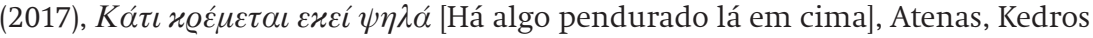

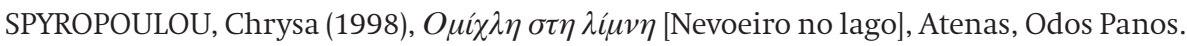

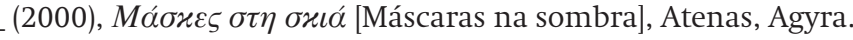

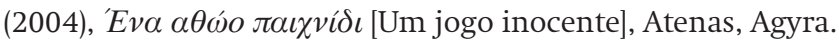
(2006), $\Delta i \chi \omega \varsigma$ í $v \eta$ [Sem rasto], Atenas, Kedros.

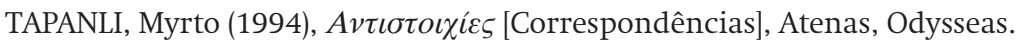

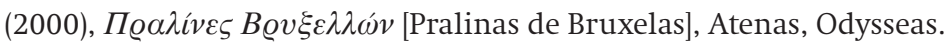

TOBROU, Ioanna (2009), Kauixo [Kamiko], Atenas, Estia.

\section{Bibliografia crítica}

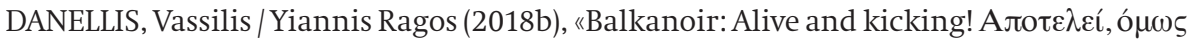

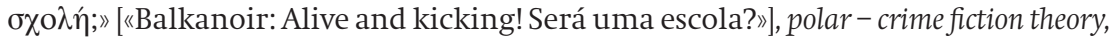
Bd. 1, Atenas, S.25-28.

FILIPPAIOS, Nikos (2017), The Beginnings of Crime Fiction in Greece: From the Late 19th Century to the 1940s, http://database.popular-roots.eu/exhibits/show/crime-fiction-in-greece

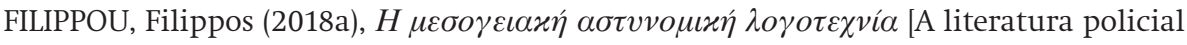
mediterrânica], https://diastixo.gr/arthra/9277-mesogeiaki-astunomiki-logotexnia.

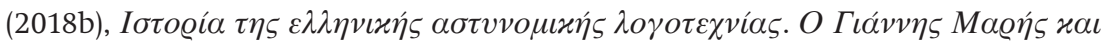

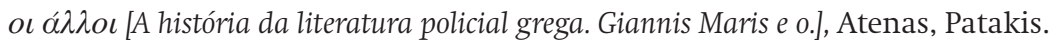

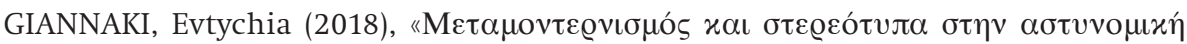
$\alpha \phi \eta ́ \gamma \eta \sigma \eta »[$ [Pós modernismo e estereótipos na narrativa policial»], polar - crime fiction theory, Bd. 1, Atenas, S.20-21.

KAISIDOU, Vassiliki (2018), Behind crime and depravity. Moral ambiguity and social constructions of evil in contemporary Greek detective fiction, in e-revista anthropino, http:// anthropino.gr

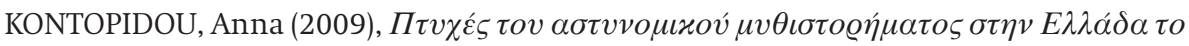

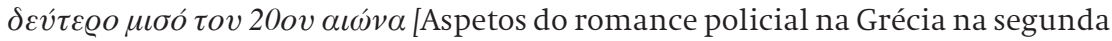
metade do século XX], trabalho de mestrado, Faculdade de Filosofia da Universidade Aristóteles de Tesalonica, especialização em filologia Grega, Atenas.

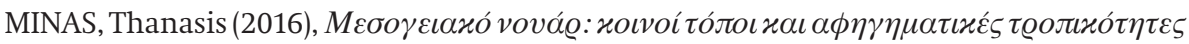
[Romance negro mediterrânico: topoi comuns e topoi narrativos], https://eglima. wordpress.com/2016/09/10/minas/

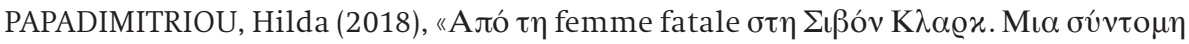

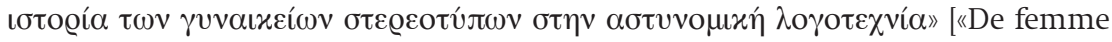
fatale a Sivon Clark. Uma breve história dos estereótipos femininos na literatura policial»], polar - crime fiction theory, Vol. 1, Atenas, pp. 17-19. 


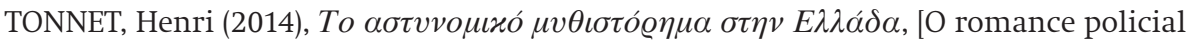

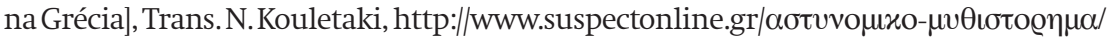

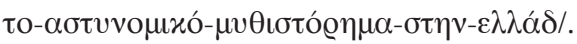

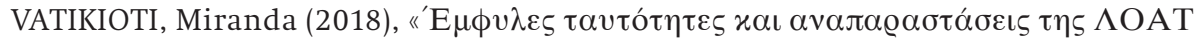

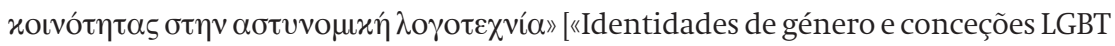
na literatura policial»], polar - crime fiction theory, Vol. 1, Atenas, pp. 22-24. 

III. Por vários continentes 



\section{Tana French's Crime Novels: Dublin After History}

Adriana Bebiano

Faculty of Letters and Center for Social Studies

University of Coimbra

Thank God that's over and done with. Time to forget the past and move on to mobile phones and shopping malls and selfesteem.

Kerry Hardie

\section{The Strange Case of the Emerald Noir}

The notorious popularity of crime fiction, in its multiple subgenres, has led to a steadfast if slow recognition in critical discourse. Yet, this is a matter of fierce debate: in academic contexts it is still deemed to be simple entertainment with no aesthetic value to speak of; as such, academia resists its legitimation as literature. Ireland is a case in point.

Irish noir, however, has enjoyed such a boost in recent years that the genre cannot be ignored by academia and what's happening in the field is worthy of note. The received knowledge speaks of a weakness, or even an absence of crime fiction, ${ }^{1}$ in a country of copious literary production, a position that can be found summarized in Ingrid Black's assertion: «the odd literary maverick aside, it had never been a particularly popular native form» (Black 2011: 14). ${ }^{2}$ As it is starting to become evident from emerging critical work, this view is highly debatable.

\footnotetext{
${ }^{1}$ For the purpose of this essay I shall not be discussing the other possible denominations of the genre in its multiple variations and shall be using «crime fiction» as an umbrella term.

${ }^{2}$ «Ingrid Black» is the pseudonym of Eilis O'Hanlon and Ian McConnel, a husband-and-wife writing team.
} 
It cannot be denied that an explosion of the genre took place in the $1990 \mathrm{~s}$ when, out of «The North», a body of serious crime novels used the Troubles as matter for a fictional reckoning with history. Indeed, the context provided ample material for treatment in this mode. Back in the 1990s I was reading OfWee Sweetie Mice and Men (1996), by Colin Bateman, Eureka Street (1996), by Robert McLiam Wilson and Eoin McNamee's Ressurection Men (1994). ${ }^{3}$ Meanwhile, in the Republic, back then no novels of this kind were getting critical attention.

When using a strict codification of the genre, Peter Tremayne ${ }^{4}$ is frequently mentioned as the precursor of crime fiction in the Republic. Absolution by Murder, the first Sister Fidelma historical mystery, came out in 1994 and Tremayne has thirty novels to his name up to the present. The series offers no doubt as to its genealogical classification and it has generated a legion of fans, gathered around the «International Sister Fidelma Society», which meets every two years, thus bearing witness to the popularity of historical crime fiction as a subgenre. ${ }^{5}$

If Tremayne's Fidelma does not raise problems as far as genealogical classification goes, "genre» is still to a wide degree a way of reading. As is often the case when a particular genre comes into fashion, an archeological critical work comes up with a plethora of forerunners, and there's plenty of those to be found in Irish literature. This archeology has come up with - for instance - Brehan Behan's The Scarperer (1963), or, even prior, Liam O'Flaherty's The Informer (1925). It should be understood, however, that only now are these novels read as crime fiction: the genealogical tag emerges from the ways of reading far more than from the novels' narrative strategies, for genres are hybrid and their readings are determined by the context. Take the Scarperer: it is a picaresque narrative; yet, picaresque is not in fashion, and the novel does let itself be read as crime;

\footnotetext{
${ }^{3}$ Bateman's novels are satires characterized by gallows humour. He has kept writing in a similar vein; Belfast Confidential (2005) is probably the better-known novel of the Dan Starkey series. McLiam Wilson - a brilliant writer - on the other hand, has moved to journalism and published no novels since 1996, much to my regret. Much the same could be said of another astounding northern Irish writer, Ronnan Bennet, whose dark novels include politically-related crime, and who has published no novels since Zugzwang (2006). McNamee went on to write other novels based on «true crime», namely his «Blue Trilogy»: The Blue Tango (2001), Orchid Blue (2010), and Blue Is the Night (2014).

${ }^{4}$ Pseudonym of Peter Berresford Ellis, an historian and specialist on Celtic Culture. Born in England of an Irish father, the action of his novels take place in 7th century Ireland and his inclusion in the corpus of Irish Literature is not an issue.

${ }^{5}$ For a discussion of the historical fiction subgenre, as well as the issue of genre hybridity, see Bebiano, 2001.
} 
able how the grammar of the genre is thus erased. If, as it seems, a cross-pollination between public popularity and academic legitimation is happening, both processes have different timings: scholarly work lags far behind popular acclaim. Or, in other words, the popularity does not entail immediate critical visibility (see, for instance, Johnsen 2014: 132-133).

In the recently published Irish Crime Fiction (2018), Brian Cliff points out the scarcity of critical work on the genre, despite its popular success signified in the big hit of the Irish Crime Fiction Festival, at Trinity College, Dublin, five years earlier, and a brain-child of Cliff's. Back in November 2013 attendance was free - circumstances have changed since then. «Murder One. Ireland's International Crime Writing Festival» (cf. http://www.murderone.ie/about-murder-one) took place in November 2018, and the ticket sale for the 2019 edition is soon to open. This event is part of the wider phenomenon of Literary Festivals which have taken root just about everywhere and are thick on the ground in both Ireland and Great Britain: crowds pay up front to see and listen to their favourite authors, in readings and interviews, and quite often events are «sold out» well in advance. In this particular field, the precursor is the «International Sister Fidelma Society Conference», whose $7^{\text {th }}$ edition took place in Cashel in September 2019 (http://www.sisterfidelma.com/main.htm). Up north, «NOIRELAND. International Crime Fiction Festival, Belfast» is having its $2^{\text {nd }}$ edition in March 2019 (https://www.noireland.com/), at the Europa Hotel. ${ }^{8}$ That Ireland has room for these many crime fiction festivals is in itself food for thought - and for the possible perception of the existence of «two Irelands», as far as crime fiction goes. Noireland is the brainchild of David Torrans, who established the «No Alibis» Bookshop, in Belfast, back in 1997. ${ }^{9}$ These phenomena are, however, quite recent in historical terms, and the discourse of scarce production in the Republic in the last century is still very much in place, and true up to some point; as always, there's an attempt to explain the phenomenon.

\footnotetext{
${ }^{8}$ The Europa Hotel is famous for being «the most bombed hotel in the world» (36 attacks during the Troubles). I should add that the North is banking on its violent past and «war tourism» is going strong.

${ }^{9}$ The resilience of this Belfast bookstore exclusively dedicated to crime fiction deserves to be noted and it has contributed to the vitality of the genre in the North. On the other hand, «Murder Ink,» famous bookstore in Dawson Street, Dublin, closed down in 2010, another victim of the migration of fiction to big companies - and, one should add, to digital support. The bookstore «No Alibis» is the setting of Colin Bateman's Mystery Man (2009), a crime fiction comedy which is also a homage to David Torrans.
} 
In an article published in The Irish Times, on the $21^{\text {st }}$ November 2009, cultural critic Fintan O'Toole argued that such scarcity was due to the absence of great urban spaces and of an economical situation friendly to this kind of fiction. Thus, the Celtic Tiger of the $1990 \mathrm{~s},{ }^{10}$ with its economic boom and correlated increase in gang-related crime, would explain the emergence of the genre. O'Toole's argument is quite seductive; yet, as a cultural journalist, he's not obliged to sustain his argument as academics are supposed to - and I find it difficult to sustain it. After all, crime stories are not dependent on urban spaces or, indeed, the actual existence of organized crime. O'Toole comes up with yet another explanation, again very seductive: due to the smallness of the communities, including Dublin, until the second half of the $20^{\text {th }}$ century, anonymity - a supposed requirement for the mystery - was impossible: everyone knew everyone else and everything that was happening (cf. O’Toole 2011). Again, this is not sustainable, given that quite a lot of crime fiction is set in small communities, Andrea Carter's contemporary mysteries, set in Inishowen, being a case in point (see Carter 2018). I would also add that provincial Dublin of the 1950s has provided Benjamin Black - aka John Banville - with plenty of material for his Quirke series. ${ }^{11}$

Underlying O'Toole's argument is the idea that crime fiction is necessarily born of the material conditions of the community - as if crime fiction were not fabulation, but a kind of document, obliged to the same veracity one requires of the social sciences. O'Toole unwittingly forgets that even realist fiction is, first and foremost, fiction. I would argue that it is fiction which produces more fiction: mimesis happens between texts and is not dependent on social reality for its existence. One needs not to go further than the «whodunnit» of the English country house or small community to see the frailty of the argument. Or take the «Nordic Noir»: now very much in fashion and having contributed to the boom of the «Emerald Noir», it certainly did not arise out of the urban problems

\footnotetext{
${ }^{10}$ The term «Celtic Tiger» was first coined by the economist Kevin Gardiner, in 1994, when comparing Ireland's economic boom to the «Asian Tigers» economies. It has since gained currency in all fields.

${ }^{11}$ Black's Quirke is a ruthless reckoning with de Valera's Ireland and a string of (true) crimes commited by Church and State. Particularly poignant are Christine Falls (2006), which addresses abortion and the adoption-ring, controled by the Catholic Church, of children born out of wedlock; and Holy Orders (2013), featuring the sexual abuses visited upon institutionalized children by men of the cloth. Unsurprisingly, the crimes of the Church also feature in quite a few novels by other authors, such as Jo Spain's With Our Blessing (2015) and Claire McGowan, The Lost (2013).
} 
of Oslo, Stockholm or Copenhagen. Long before it took off this century, much due to the global success of Stieg Larson's Millenium trilogy (2005-2007) (see Bergman, 2014), Maj Sjöwall and Per Wahlöö had written the now famous Martin Beck's series, starting with Roseanna, first published in $1965 .{ }^{12}$

On the other hand, one of the possible partial explanations for the relative scarcity of crime fiction in Ireland until the 1990s might be the cultural isolation of the country up until the 1970s, under the strict citizen's control and invigilation by a rather conservative state in cohorts with the Catholic Church. ${ }^{13}$ The list of prohibited publications in the «Censorship of Publications Act» of 1929 addresses the expected issues - «indecent or obscene or (...) advocated the unnatural prevention of conception or the procurement of abortion or miscarriage or the use of any method, treatment or appliance for the purpose of such prevention or such procurement» - but also publications which «devoted an unduly large proportion of space to the publication of matter relating to crime». This, of course, covered crime fiction magazines, mostly from the United States of America, easily affordable and instrumental for the propagation of the genre. ${ }^{14}$

It's highly possible that the «scarcity» discourse results from the absence of legitimation - and that's where the universities have a role to play. The first university course on crime fiction was created precisely by Ian Campbell Ross, in the School of English, at Trinity, in 1990, in the face of the hostility of the Department (Meier and Ross 2014: 11). ${ }^{15}$ Almost three decades later, critical studies are still thin in the field, as Cliff claimed as recently as 2018. It's worth to take a look at what's happening.

From an overview of recent essays covering crime, two trends emerge: there's plenty on true crime but far less on fiction; there's little critical discourse, as

\footnotetext{
${ }^{12}$ Published in Portuguese translations by Caminho, in the 1990s.

${ }^{13}$ Article 44.1. of the Irish Republic's Constitution of 1937 stated in no uncertain terms: «The State recognizes the special position of the Holy Catholic Apostolic Roman Church as the guardian of the Faith professed by the great majority of citizens». This section was deleted by the Fifth Amendment of The Constitution Act 1972, following a referendum.

${ }^{14}$ See list in «Censorship of Publications Acts, 1929 to 1967 Register of Prohibited Publications», available in the Republic of Ireland's Ministry of Justice website: http://www.justice.ie/en/JELR/Register\%20of\%20Prohibited\%20Publications\%202012.pdf/Files/Register\%20of\%20Prohibited\%20Publications\%202012.pdf (Access: December 2018).

${ }^{15}$ As an undergraduate of Anglo-American Studies, at the University of Coimbra, Portugal, I took a course in crime fiction as early as the academic year 1981-1982. In November 2000, Gonçalo VilasBoas and Maria de Lurdes Sampaio hosted the «Encontro de Literatura Policial» at the University of Oporto, to the best of my knowledge, the first academic event in the field to take place in Portugal.
} 
compared to fans' or authors testimonials. Looking at The Sister Fidelma Mysteries. Essays on the Historical Novels of Peter Tremayne, edited by Edward J. Kielley and Robert David Wooten in 2012, for instance, one finds that there's plenty of essays written by amateurs while literary criticism is absent. On the other hand, Down These Green Streets: Irish Crime Writing in the 21st Century (2011), edited by Declan Burke, includes two very useful critical essays. Apart from these, however, the volume includes only interviews and personal narratives by authors - mostly men - on the process of writing, as well as short-stories. I find also significant that Niamh O'Connor, crime reporter, author of true crime reports and also crime novelist, for this volume has chosen to write about true crimes. ${ }^{16}$ Burke may well be right when he writes, in his introduction to the volume: «for the most part Irish crime writers are more celebrated outside of Ireland than they are at home» (2011:10). In 2014, the journal Éire-Ireland had a special issue dedicated to «Irish Crime Scene since 1921». Of its nine essays only three address fiction - one of which only partially - while most deal with law, history and crime journalism, covering petty criminality, sexual crimes and the political violence in the context of the Troubles. This can be taken as yet another evidence of the frailty of the critical work.

Along with the occasional essay, The Contemporary Irish Detective Novel, a collection edited by Elizabeth Manion, as well as Brian Cliff's 2018 monograph, Irish Crime Fiction, may well indicate that the tide is turning in academia - possibly riding the Nordic Noir market phenomenon. The word is that it was Val McDermid, awarded Scottish author, who coined the expression «Emerald Noir», ${ }^{17}$ a variation of the now very popular «Nordic Noir,» of which I am also a fan. It is a brand that sells, yet I would tend to agree with Declan Burke's caution, back in 2014: “'Emerald Noir' is unlikely to ever rival 'Nordic Noir' as a global phenomenon (...)». ${ }^{18}$ Four years later, his reading is still to be disproved.

\footnotetext{
${ }^{16}$ O'Connor's detective, DI Jo Birmingham, a divorced mother of two, gives material for a good discussion of feminist rewriting of characters - (cf. O'Connor 2010) - not the aim of this essay.

${ }^{17}$ McDermid came up with «Celtic Crime», «Hibernian Homicide» and «Emerald Noir»; the last one stuck, perhaps due to the «Nordic Noir» resonance. See McDermid in interview to Gerard O'Donovan for The Telegraph, in 8th March 2011: https://www.telegraph.co.uk/culture/tvandradio/8368248/ Val-McDermid-why-Irish-crime-fiction-is-all-the-rage.html (Access: January 2019).

${ }^{18}$ In https://www.independent.ie/entertainment/books/book-reviews/emerald-noirs-genrebending-take-on-the-crime-novel-30726270.html. (Acess: December 2018). The comparison has now entered the lingo: Johnsen is a case in point, putting it in terms of «one route to an international influence» (2014:139).
} 
If not in the critical work, a glimpse in bookshops or crime festivals' programmes prove the prolixity and variety of contemporary Irish crime. Anyone familiar with Irish literature - and, indeed, with Irish literary criticism - will acknowledge that there is an excess of identity-focused writing, and it seems that discussion on crime is no exception. In her interview with Tana French, Claire Coughlan claims:

The explosion of crime fiction in Ireland in recent years has coincided with a new appraisal of what it means to be Irish, which in turn has seen the genre occupy a more central position on the Irish literary spectrum. (Coughlan 2011: 341)

Could it be that this obsession with Irishness is yet little more than a way of reading? As Black puts it hilariously, «in Ireland [...] national traits are cultivated the way some countries grow rhubarb» (Black 2011: 12), and goes on to praise the new writing coming out because «freed from the tyranny of authenticity» (idem: 15).

In such cases a view from the outside might be helpful. In the «Foreword» to Down These Green Streets, American bestseller crime novelist Michael Connelly states: "But then I started reading the stories and the essays and I came to realize there is a universal language in the crime story. What Tana French does in Dublin I try to do in Los Angeles. (...) We're all in this together and there is only the language of storytelling» (Connelly 2011: 12). This statement makes perfect sense: if novelists use "the matter of Ireland» for their stories, that does not make «Irishness» the issue. Again, looking from the outside, I find Irishness problematized only in a few stories set in the North and which deal with the history of the Troubles and its aftermath - Brian McGilloway's Benedict Devlin and Lucy Black series would be a case in point. Apart from a few exceptions, even when documenting the changes in Irish contemporary society - north and south of the border - crime fiction has moved beyond the obsession with identity to focus on issues that pertain to all humans anywhere, such as how to survive poverty and personal loss.

One could make a case for «class» as a central issue in recent crime fiction. While the rural poor and the urban middle-class occupy the heart of $20^{\text {th }}$ century Irish fiction, it could be claimed that the contemporary urban working-class has his writer in Roddy Doyle, most famously in his Barrytown Trilogy, three novels adapted into movies that had great impact in the 1990s: The Commitments 
(1987, film 1991); The Snapper (1990, film 1993); The Van (1991, film 1996). However, this trilogy is a pastoral, ${ }^{19}$ given that even if the characters have fierce fights, it's still a family connected by love and a sense of loyalty to the clan. Furthermore, the Rabbittes, a working-class family from Dublin, are «great crack», as the Irish idiom goes. There's no such romance in Tana French's portrait of Dublin's working class.

\section{Cherchez la femme: Irish Women Crime Writing}

The last decades have seen a strong international movement in self-conscious feminist criticism which has both promoted contemporary women's writing as well as reclaimed writing by women of the past, thus reconfiguring national literature canons. I won't be going into this here: the specialized literature is abundant. Suffice it to say that this movement is very strong in Irish Literature. Crime fiction, understood as a male genre, particularly in the hardboiled American tradition, has been addressed from a feminist perspective, which includes the reclaiming of women writers for the canon as well as critical work on novels understood to comprise feminist rewritings of the tradition (see Peach 2006; Munt 2005). It is my perception, however, that in Ireland crime fiction written by women has largely been kept in a ghetto.

Irish feminist rewriting of the canon has its stronger and symbolical referent in the publication of The Field Day Anthology of Irish Literature, Vols 4 \& 5: Women's Writings and Traditions (2002). Two thick volumes which were more than a decade in the making, they sought to redress women's absence in the literary canon, only too apparent in the previous (also thick) three volumes of The Field Day Anthology of Irish Literature, a huge project coordinated by Seamus Deane (see Bourke 2002; and Deane 1990). Crime fiction, however, is excluded from this extensive work with the ambition of being all-inclusive. Furthermore, as scholars well know, apart from providing useful cartographies for different fields, anthologies are powerful tools to promote literary work: one quite often firstly comes across an author in an anthology - not to speak of the fact that they are quite useful for teaching and, thus, assured promotion of authors. On the other

\footnotetext{
${ }^{19}$ It must be said, however, that Doyle's latter novels The Woman Who Walked into Doors (1996) and Paula Spencer (2006), are far darker and deconstruct the romance of the working class.
} 
hand, critical surveys are also useful for teaching and also powerful tools: they set what is to be remembered and what forgotten. Having said this, it should be noted that crime fiction is absent from A History of Irish Women's Literature, edited by Heather Ingman and Clíona Ó Gallchoir as recently as 2018.

Or almost absent. In fact, Susan Cahill's essay for this volume, significantly titled «Celtic Tiger Fiction,» includes a section under the symptomatic head «Chick Lit and Crime Fiction» (Cahill 2018: 437-439). The coupling is noteworthy because, if crime fiction is on probably the way out of being labeled «trash,» certainly not the same can be said of «Chick Lit». ${ }^{20}$ Also of note is the title of the immediately following section in Cahill's essay, «Aesthetic Creation». The critic thus opposes - perhaps unwittingly - the trashy subgenres to literature "proper», showing how legitimation is a long way off. Cahill puts in a good word for Tana French (cf. p. 438), by linking her with recognized «serious» authors such as Anne Enright and Éilis Ní Dhuíbhne; it should be noted, however, that this is written by way of a critical essay by Shirley Peterson, which goes to show the importance of critical work done from within the field by recognized scholars (cf. Peterson 2016). ${ }^{21}$

It goes without saying that writing by women authors is not necessarily «feminist» - nor does it need to be. Yet, there is quite a number of women writing crime fiction who need to be made visible but do not need greater scrutiny than male writers. The list is long, comprising both excellent and indifferent novels sprouting in response to a growing market. Without aiming at being exhaustive I would name Andrea Carter, Arlene Hunt, Catriona King, Claire McGowan, Gemma O’Connor, Jane Casey, Jo Spain, Kelly Creighton, Liz Nugent, Niamh O'Connor and Tana French. A visit to sites concerning the genre does provide far more names; yet, as expected, not everyone riding the wave provides sufficient pleasure in the reading and it is the responsibility of critical work to value good writing. One of the arguments for discrediting crime fiction is that it is just «formula writing,» providing for the modest pleasure of «reading for plot». Simple repetition may satisfy most readers; however, the legitimation of the genre as literature requires looking beyond it. Repetition makes for boring reading - and literature, even «entertainment literature» is not in the business

\footnotetext{
${ }^{20}$ One of the many crime fiction subgenres now exant migt be called «Crime chick lit», Sinéad Crowley's D S Claire Boyle series being an example. See Crowley 2014.

${ }^{21}$ It must be said that Peterson (2016) also reads French's work as emerging out of the post-Celtic Tiger, a reading which I find rather limiting.
} 
of boring; "good writing» - that elusive category - must be driven by character and work on language as well as plot. If formula books are defined by plot, what makes a "genre book» literature is the development of character. I would claim that it is also what makes it transnational, in the sense that it is a representation of the human in all its complexities, even if the material social circumstances of the characters are diverse and linked to a specific time and place.

Labeling a novel as «feminist» is also an ambiguous issue. Johnsen's claim that «[Gemma] O'Connor's feminism is notably absent from French's work» (Johnsen 2014: 126-127) is highly arguable. I take as «feminist» the figuration of characters and of power relations that question gender stereotypes and provide positive role models for women, that is, «feminist» in the sense that they reconfigure femininity and masculinity. Thus, Claire McGowan's Detective Paula Maguire is an example of feminist rewriting of characters. Paula has a set of behaviours that might be characterized as «male»: a single 30-year-old woman with no children, who left her hometown in the borders for Dublin and then London, traumatized by the Troubles, the disappearance of her mother and a love story gone wrong, Paula is no «lady». One might even say that she behaves «disgracefully»: she can't cook or keep her fridge stocked, she drinks pints of Guinness with the lads and does not fear physical confrontations. Last but not least - and because the codes of sexual behaviour are still the rule of thumb to distinguish the male and the female of the species - when she has one-night stands, she can't wait for the man to be gone in the morning with no necessity of small talk or of feeding him breakfast, a typical male character behaviour. ${ }^{22}$ This simple gender inversion of characters can be found in feminist rewritings across genres $^{23}$ and it is recognizably «feminist» in the sense that it reconfigures women. It has a long tradition in crime fiction: Sara Paretsky's Chicago private eye V.I. Warshawski has been doing the rounds since 1982 (see Paretsky 1982). In this sense, Tana French's novels are feminist; they are, however, far more concerned with problematizing the human in general - our fears and desires, hopes and despairs, the daily concerns that happen to be set in Dublin but could also be called our own in another place.

\footnotetext{
${ }^{22}$ See, for instance, The Lost (2010), the first book in the series.

${ }^{23}$ Feminist rewriting of fairy-tales would be a case in point. See Bebiano 2013.
} 
demons to live with. Antoinette Conway longs for her unknown father; Frank Mackey's perfect bourgeois life hides a past in a working class neighbourhood and a violent father; Cassie Madox is perhaps the darker and most elusive subject - not by accident, she works Undercover -, and her secret is yet to be disclosed.

The (fictional) Dublin Murder Squad is the elite of the Garda Síochána - the Republic of Ireland's police corps - only surpassed in status by the Undercover Unit. Throughout the six novels, the group of men and women that comprise the squad is fairly stable, with the occasional rookie coming in and the occasional drop-out unable to sustain the pressure - Richie Curran, in Broken Harbour, is a case in point. What I find remarkable is that to be accepted in the Murder Squad is presented as the ambition of every garda, signifying social promotion and an escape from the city's council estates, a strategy that places class and social mobility issues as the axis of the novels.

Antoinette, Moran and Mackey hail from «the wrong side of the river»North Dublin - and police work grants an escape from the council houses; yet they represent different attitudes towards class and the social structure. The differences are seen at its best in The Secret Place, involving the murder of a sixteen-year old boy at St. Colm, an upper-class school for boys, and its neighbor and correspondent for girls, St. Kilda. The case is assigned to Steve Moran - the narrator - and Antoinette Conway. On arriving at St Kilda for the first time, Moran's thoughts tell us of the class difference, but also of his ambivalence and longing to belong:

Maybe I should have hated it. Community-school me, classes in run-down prefabs; keep your coat on when the heating went every winter, arrange the geography posters to cover the mould patches, dare each other to touch the dead rat in the jacks. Maybe I should have looked at that school and wanted to take a shite in the portico. It was beautiful. I love beautiful; always have. I never saw why I should hate what I wish I had. Love it harder. Work your way closer. Clasp your hands around it tighter. Till you find a way to make it yours. «Look at that», said Conway. Leaning back in her seat, eyes narrow. "This is the only time I'm sorry I'm a cop. When I see a shitpile like this and I can't petrol-bomb it to fuck». (French 2014: 35)

theory as well as postcolonial theory, Shirley Peterson reads all of French's novels as «trauma narratives»: «These police procedurals illustrate how the detective genre can express, through both subject and narrative method, the destabilizing influence of trauma on both individual and communal levels» (108). To my mind, this reading is contrieved, and is an example of the influence of postcolonial criticism in contemporary Irish literary studies. 
Where Moran sees beauty and something to aspire to, Conway sees the other side, the enemy, something she not only does not wish to access herself but wishes to "petrol-bomb it to fuck». Language is significant here: foul language is a common device to characterize working class people, and one which French uses; it's also part of the conventional «police talk». However, neither Moran nor Mackey make use of it, thus distancing themselves from their class or origin; on the other hand, Conway uses it frequently, claiming and asserting her roots. In The Secret Place, it's also part of the gender role inversion, her toughness contrasting with Steve Moran's mildness and politeness, in the line of the feminist rewriting of characters.

If there's a dimension of social realism in French's novels, it's in the way class and social mobility is portrayed. In this process, access to education has replaced the possession of land - central to $20^{\text {th }}$ century Irish fiction - as the main asset for ambitious young people, with the «Leaving Cert» as the threshold and the symbolical first goal to be achieved. In The Trespasser, where we find that Antoinette is the mixed-race daughter of a single mother who chars for a living, we are told:

That lasted till I was twelve and got detention for something, and got an earful from my ma about how she wasn't having me end up like her, with no Leaving Cert and no hope of anything but minimum-wage. (French 2016: 1)

While Conway's voice comes out as a ranting, in The Secret Place Steve Moran, her partner, tells a very similar story as an achievement, something to be proud of:

Two years behind me, in training. Got out of uniform one year behind. Made Murder the same time I made Cold Cases. Cold Cases is good. Very bleeding good for a guy like me: working-class Dub, first in my family to go for a Leaving Cert instead of an apprenticeship. (French 2014: 14)

Also noteworthy is that «the other side» of the class divide is signified by the posh schools for teenagers, but also by Trinity College, which comes up in the PhD students inhabiting the Big House in The Likeness, as well as in the geography referred to by Mackey in Faithful Place, set in The Liberties, a self-conscious working-class area with its own ethos: «it's a ten-minute walk from Trinity Col- 
lege and the snazzy shopping on Grafton Street, but back in my day, we didn’t go to Trinity and the Trinity types didn't come up our way» (French 2010: 19).

Education is represented as the only chance for social mobility, but it comes at a price, as exemplified in Frank Mackey's case. It's a rather common story: the sacrifice of the older siblings so that the younger could get a chance, as explained by Shay, Frank's older brother:

What makes you any smarter? Just because me and Carmel were out of school the second we turned sixteen? Did you think that was because we were too thick to stay?' Shay was leaning forward, hands clenched on the edge of the table, and there was a patchy fever-red flush coming up on his cheekbones. «It was so we'd be putting our wages on the table when Da wasn't. So you could eat. So the three of you could buy your schoolbooks and your little uniforms and get your Leaving Certs». «(...) 'Without me, you wouldn't be a cop today. You'd be nothing. You thought I was just mouthing off when I said I'd die for family? I damn near did it. I lost my education. I gave up every chance I had'». (idem: 139)

The working-class ethos implies «to die for family», even when family kills (and it does). Family dynamics and the complexity of feelings between siblings, as well as between parents and children are an important feature in all novels, setting them in an uncertain geography: it may be Dublin, but one quite often forgets it's Dublin; it could be anywhere where people breed, and love seems never to be enough to go around.

«Crime» comes in many forms. Arlene Hunt's novels, for instance, focus on contemporary criminal phenomena, such as human trafficking, fictionalized in Undertow (2008). In this kind of novels «bad guys» are set apart from «normal» people and crime can be identified and fought, if not eradicated. In Tana French, it is the «normal» people who commit crimes, both petty crime and the gross killings at the center of the plots. The Liberties are no strangers to crime, as Frank Mackey makes clear:

Cops like me are the reason why you never get posted where you're from. If you want to get technical, everyone I grew up with was probably a petty criminal, one way or another, not out of badness but because that was how people got by. Half the Place was on the dole and all of them did nixers, specially when the beginning of the school year was coming up and the kids needed books and uniforms. (idem: 34$)$ 
Working class neighbourhoods have a history of resistance to the state and law, as clearly expressed when neighbours gather for a drink under different pretexts: «the crowd settled down, gradually, and started swapping police-brutality stories and discussing whether Mr Daly could sue» (idem: 94). Swapping stories is another important feature in these novels, where certainties are few and open to be disproved by another voice, sometimes in another novel further down. Knowing that all characters lie, and that the quest for knowledge is bound to be a failure, all we're left with are the stories, in their multiplicity, as the lucid voice of Antoinette Conway tells us towards the end of The Trespasser:

Another story. None of the rest were true straight through, not one. Victims, witnesses, killers, Ds, all frantically spinning stories to keep the world the way they want it, dragging them over our heads, stuffing them down our throats (...). (French 2016: 454)

«Another story» has replaced «history», in this and other novels. Stories help us making sense of our lives - and it must suffice.

\section{Works Cited}

BATEMAN, Colin (2009), Mystery Man. London: Headline. Kindle. (2005), Belfast Confidential. London: Headline.

BEBIANO, Adriana (2013), «Para uma pedagogia política e lúdica: reescritas 8 feministas de contos de fadas», in Ana Luís (org.), Ensino do Inglês: contributos para uma prática multidisciplinar, 145-175.

(2001), «Um híbrido feliz: o policial histórico», in Sampaio, Maria de Lurdes/ Gonçalo Vilas-Boas (eds.), Crime, detecção, castigo: estudos sobre literatura policial. Porto: Granito, 153-165.

BENETT, Ronan (2007), Zugzwang. London: Bloomsbury.

BERGMAN, Kerstin (2014), Swedish Crime Fiction: The Making of the Nordic Noir. Mimesis International.

BLACK, Benjamin (2013), Holy Orders. New York: Henry Holt and Company. (2006), Christine Falls. London: Picador.

BLACK, Ingrid (2011), «Escaping Irishness», in Declan Burke, Down These Green Streets: Irish Crime Writing in the 21st Century. Dublin: Liberties Press. 211-219. [Kindle-book]. 
BOURKE, Angela et alii (eds.) (2002), The Field Day Anthology of Irish Writing. Vols. 4 \& 5: Irish Women's Writing and Traditions. Cork: Cork University Press.

BURKE, Declan (2011), Down These Green Streets: Irish Crime Writing in the 21st Century. Dublin: Liberties Press [Kindle-book].

CARTER, Andrea (2018), Murder at Greysbridge. London: Hachette. Kindle.

CAHILL, Susan (2018), «Celtic Tiger Fiction», in Heather Ingman and Clíona Ó Gallchoir (eds.), A History of Irish Women's Literature. Cambridge: Cambridge University Press, 426-444.

CLIFF, Brian (2018), Irish Crime Fiction. London: Palgrave Macmillan.

CONNELLY, Michael (2011), «Forerword», in Declan Burke (ed.). Down These Green Streets: Irish Crime Writing in the 21st Century. Dublin: Liberties Press, 12-13. Kindle.

COUGHLAN, Claire (2011), «Paper Tiger: An Interview with Tana French», in Declan Burke (ed.), Down These Green Streets: Irish Crime Writing in the 21st Century. Dublin: Liberties Press, 335-344. Kindle.

CRAIGHTON, Kelly (2015), The Bones of It. Belfast: Incubator Editions. Kindle.

CROWLEY, Sinéad (2014), Can Anybody Help Me? London: Quercus. Kindle.

DEANE, Seamus et alii (1990), The Field Day Anthology of Irish Literature. Derry: Field Day Publications.

FRENCH, Tana (2016), The Trespasser. London: Hodder \& Stoughton. Kindle. (2014), The Secret Place. London: Hodder \& Stoughton. Kindle. (2012), Broken Harbour. London: Hodder \& Stoughton. Kindle. (2010), Faithful Place. London: Hodder \& Stoughton. Kindle. (2008), The Likeness. London: Hodder \& Stoughton. Kindle. (2007), In the Woods. London: Hodder \& Stoughton. Kindle.

HUNT, Arlene (2008), Undertow. Dublin: Hachette Books Ireland. Kindle.

INGMAN, Heather/ Ó Gallchoir, Clíona (eds.) (2018), A History of Irish Women's Literature. Cambridge: Cambridge University Press.

JOHNSEN, Rosemary Erickson (2014), «Crime Fiction’s Dublin: Reconstructing Reality in Novels by Dermot Bolger, Gene Kerrigan, and Tana French», in «Irish Crime Since 1921», Special Issue, Éire-Ireland 49, no. 1-2 (Spring-Summer 2014), 121-141.

KIELLY, Edward J./ Wooten, Robert David (2012), The Sister Fidelma Mysteries. Essays on the Historical Novels of Peter Tremayne. Jefferson and London: McFarland \& Company.

MAGENNIS, Caroline (2018), «Fiction from Northern Ireland, 1921-2015», in Heather Ingman and Clíona Ó Gallchoir (eds.), A History of Modern Irish Women's Fiction. Cambridge: Cambridge University Press, 365-382.

MANNION, Elizabeth (ed.) (2016), The Contemporary Irish Detective Novel. London: Palgrave Macmillan.

(2016), «Irish by blood and English by accident': Detective Constable Maeve Kerrigan», in The Contemporary Irish Detective Novel. London: Palgrave Macmillan, 121-134. 
McGOWAN, Claire (2013), The Lost. London: Headline. Kindle.

McDERMID, Val/ O’Donovan, Gerard (2011), «Val McDermid: why Irish crime fiction is all the rage», The Telegraph, $8^{\text {th }}$ March 2011: https://www.telegraph.co.uk/culture/tvandradio/8368248/Val-McDermid-why-Irish-crime-fiction-is-all-the-rage.html (Access: January 2019).

MEIER, William/ Ross, Ian Campbell (2014), «'Editors’ Introduction», in «Irish Crime Since 1921», ed. Meier and Ross, [special issue], Éire-Ireland 49, no. 1-2 (Spring-Summer 2014), 7-21.

MUNT, Sally Rowena (2005 [1994]), Murder by the Book? Feminism and the Crime Novel. Taylor and Francis. Kindle.

O'CONNOR, Niamh (2011), «The Executioners' Songs», in Declan Burke (ed.), Down These Green Streets: Irish Crime Writing in the 21st Century. Dublin: Liberties Press, 145-200. Kindle.

(2010), If I Never See you Again. Random House. Kindle.

PARETSKY, Sara (1982), Indemnity Only. London: Penguin Books.

PETERSON, Shirley (2016), «Voicing the Unspeakable: Tana French’s Dublin Murder Squad», in Elizabeth Mannion (ed.) The Contemporary Irish Detective Novel. London: Palgrave Macmillan, 107-120.

PEACH, Linden (2006), Masquerade, Crime and Fiction. Criminal Deceptions. London: Palgrave Macmillan.

RIGGS, Pádraigín/Vance, Norman (2005), «Irish Prose Fiction», in Joe Cleary and Claire Connolly (eds.), The Cambridge Companion to Modern Irish Culture. Cambridge: Cambridge University Press, 245-266.

ROSS, Ian Campbell (2011), «Introduction», in Declan Burke (ed.), Down These Green Streets: Irish Crime Writing in the 21st Century. Dublin: Liberties Pres, 14-35.

SPAIN, Jo (2015), With Our Blessing. London: Quercus. Kindle.

STASIO, Marilyn (2007), «Repeat Offenses». NYTimes.com. 20 May 2007. https://www.nytimes. com/2007/05/20/books/review/Crime-t.html (Access: January 2019).

TODOROV, Tzvetan (1981 [1978]), Os Géneros do discurso. Trad.: Ana Mafalda Leite. Lisboa: Edições 70.

WILSON, Robert McLiam (1998), Eureka Street. London: Vintage. 


\section{As deslocações da visão \\ ou a coscuvilhice do olhar alucinado: Quando o observador se move à distância}

Carlos J. F. Jorge

Universidade de Évora

O livro de Paula Hawkins The Girl on the Train (2015 - Fev.) traduzido, de imediato, para português, em Portugal (A Rapariga no Comboio - 2015 - Jun.), foi um sucesso editorial. O filme, acto contínuo, preparado para rodagem, tentando aproveitar o vórtice criado pelo acolhimento do livro, foi estreado em Portugal dois dias antes da sua projecção inaugural nos EUA. Apresentado pouco mais de ano e meio depois da publicação do livro, o filme não teve o mesmo acolhimento entusiástico. E, devemos dizê-lo desde já, em grande parte isso pode ter-se devido ao mecanismo narrativo, fundamentalmente diferente, que funcionou no filme, não ter podido apanhar o fundamental que constitui a estrutura temática, imaginária e ideológica que o livro apresenta.

Parece-nos que podemos aproveitar o exercício de algumas breves comparações entre as duas obras, em traços largos, para podermos aprofundar com mais segurança o funcionamento do livro, tendo em atenção a visão do mundo que ele constrói. Aquilo a que podemos chamar, simplificadamente, a adaptação do livro ao cinema, servirá, no desenvolvimento do nosso trabalho, como instrumento complementar, para apreciar o funcionamento da obra literária em causa, sem prejuízo do valor intrínseco da obra cinematográfica, que poderá merecer-nos algumas considerações específicas, mas que não pretenderemos avaliar de modo tão alargado como tentaremos fazer com a literária.

Esta utilização comparativa, não se pode reduzir, no entanto, a mero emprego instrumental da obra cinematográfica. Ela permite-nos, complementarmente, enquadrar de modo mais completo a narrativa literária em causa, no todo cultural em que se expandiu, para podermos apreciar melhor toda a dimensão criativa que a obra realizou, tendo em conta algumas dimensões da recepção, através do modo como o filme se apresenta enquanto leitura e processo hermenêutico, que tem como objecto o livro. 
Uma das características que se destacou, aos olhos de muitos leitores, autores, por sua vez, de textos de crítica literária e de crítica cinematográfica que, através do filme, acaba por se referir ao livro, é a sua estrutura narrativa tripartida. O livro tem, efectivamente, quase em exclusivo, três narradoras: Rachel, Megan e Anna. É claro que fica esquecida, por assim dizer, a actuação da autora, que parece totalmente ausente da diegese, ou seja, do universo construído pelos actos narrativos, a sua apreciação, avaliação e crítica. Porém, olhando mais atentamente, verificamos que a intervenção autoral é forte e ampla, dando, por assim dizer espaço e ocasião a que as narrativas aparentemente dominantes e exclusivas se subordinem e ordenem segundo o desígnio superior do autor, a que podemos chamar implícito ou implicado. ${ }^{1}$

Há mérito, sem dúvida, neste processo que, sem grande ousadia, podemos dizer nasceu da congeminação de um dos grandes romancistas ingleses, William Makepeace Thackeray, no frontispício do seu Vanity Fair que intitulou «Before the Curtain»: «As the manager of the Performance sits before the curtain on the boards and looks into the Fair, a feeling of profound melancholy comes over him in his survey of the bustling place». ${ }^{2}$

Esta é a alegoria introdutória, que Wayne Booth transforma em enunciado teórico, no seu livro, The Rhetoric of Fiction: «whether as stage manager, as puppeteer, or as an indifferent God, silently paring his fingernails». ${ }^{3}$ Esta perspectiva

\footnotetext{
${ }^{1} \mathrm{O}$ termo implicado tem tido a preferência de alguns estudiosos. Talvez pelo tema que, frequentemente, abordamos na análise e crítica literárias dos romances policiais, implicado tem-nos parecido sempre carregado pelo sema judicial e acusatório, típico do interrogatório policial em detrimento do sentido narratológico que pretendemos manter.

${ }^{2}$ Este frontispício não aparece em todas as edições, sobretudo nas de maior divulgação. Seguimos o texto da edição acessível em http://www.planetpdf.com/planetpdf/pdfs/free_ebooks/vanity_fair_nt.pdf pág. 2, consultada em 7 de Maio de 2019.

${ }^{3}$ Esta formulação é citada, aqui, segundo a edição de The Rhetoric of Fiction, de 1961, da The University of Chicago Press, p. 151. Mas o Autor apresentou, no mesmo ano, num artigo publicado com o nome «Distance and Point-of-View: An Essay in Classification» em Essays in Criticism, Volume XI, Issue 1, 1 January 1961, Pages 60-79, Oxford, consultável em https://doi.org/10.1093/eic/XI.1.60, uma versão muito semelhante do mesmo enunciado teórico que se tem mantido válido em todos os debate de aprofundamento da matéria em causa, mesmo que as perspectivas se revelem polémicas. A tradução francesa do artigo encontra-se na revista Poétique, n.. 4, Seuil, 1970.

Citando Booth, Aguiar e Silva na terceira edição da sua Teoria da Literatura, de 1973, p. 267, afirma o seguinte (enunciado que não manterá em edições posteriores): «Há romances em que o narrador não está concretamente representado, fundindo-se a sua função com a do autor implícito, esse 'segundo eu' do autor que está 'escondido nos bastidores, na qualidade de encenador, de titereiro, ou um deus indiferente limando silenciosamente as suas unhas'». Confundido com o narrador heterodiegético, da terminologia de Genette, o conceito deste não nos seria útil, no caso presente, porque, encarado deste modo, uma tal função estaria no mesmo patamar de enunciação que ocupam os narradores
} 
nal que introduz uma nota de demoníaco em cada uma das protagonistas, percebe-se, a partir de um determinado ponto da primeira parte do conjunto de narrativas, que os processos vivenciais de qualquer das intervenientes estão marcados por momentos catastróficos e traumáticos, que as arrastam para os extremos do arrebatamento.

Qualquer delas é atingida, num momento crucial de uma ou mais relações amorosas, pelo toque do mal, proveniente de um desencanto, de uma frustração ou mesmo de uma acção desgraçada, envolvendo pontos matriciais das relações afectivas: a morte do irmão, num desastre de mota, a morte de uma filha, em resultado do seu descuido maternal, e do uso das drogas, no caso de Megan, seguida pela fuga do companheiro, pai da criança; a incapacidade de engravidar de Rachel, seguida do abandono por parte do marido em situação adulterina, que a encaminha para o alcoolismo; e a instabilidade de Anna, na salvaguarda do seu lar, e na protecção da sua filha, bem como na salvaguarda do matrimónio, sob o domínio da má consciência por ter ido ocupar o espaço íntimo e doméstico da ex-esposa do marido, que foi abandonada por este, separação motivada pela sua intromissão adulterina.

Estes desaires passionais, na mundivivência, acabam por transtornar a própria mundividência das três personagens narradoras, que entram num processo de catábase, até à porta dos infernos ou mesmo da fixação, sem regresso, nas regiões demoníacas. Todo o contorno destes percursos e dos gestos fundamentais que os tornam irremissíveis, colocando-se num ponto vivencial sem retorno, de que as personagens têm uma visão mais ou menos lúcida, mais ou menos inconfessável, não são facilmente observáveis de fora. As narradoras só atingem o conhecimento de si próprias ou o lugar em que os problemas existenciais que as dominam e abalam se encontram, por acção da entidade autoral, essa manipuladora dos discursos efectuados pelas narradoras autodiegéticas.

As correntes de consciência que aparecem, só têm sentido verbalizadas pelo dispositivo de produção da instância autoral, como diria Dorrit Cohn, que, tornando-se implícita, manipulando oculta, ou revelando omniscientemente os pensamentos das personagens, consegue torná-los transparentes para os leitores. ${ }^{5}$

\footnotetext{
${ }^{5} \mathrm{Na}$ consideração de algumas matizes na apresentação da vida interior das personagens, sobretudo na relação que, no texto, surge entre a voz que conta e a perspectiva segundo a qual ela conta, entendida como vivência humana, parece-nos de particular interesse a tipologia de Dorritt Cohn (1981[1978]). Embora devedora, nos seus pontos de partida, a Genette, ela introduz, actualizando-as, as concepções dessas relações nos estudos narratológicos alemães e anglo-americanos. A questão,
} 
Trata-se, na formulação da autora alemã, neste caso, da apresentação de «monólogo relatado», ou seja, do «discurso mental de uma personagem» ou várias. No fundo, por efeito dessa manipulação, bem visível nas indicações temporais e atribuições nominais, aquilo que aparenta ser um discorrer normal das personagens, sua corrente discursiva espontânea, está mais perto do procedimento que Dorrit Cohn chama monólogo narrado ou narrativizado (narrated monologue). ${ }^{6}$ Uma das razões porque o filme se torna mais confuso, esquemático, e, até, infrutiferamente enigmático, é o facto de não se terem procurado processos próprios do olho ciclópico da objectiva, capazes se suprirem a ausência do discurso verbal. ${ }^{7}$

É claro que o discurso fundamental que aqui se nos apresenta, é o de Rachel, e por várias razões. Em primeiro lugar, é ela que introduz, pelo seu discorrer, a ideia de que os acontecimentos que se apresentam, resultam de um acto de visua-

tal como ela a coloca, não se reporta apenas a problemáticas linguísticas mas, também, com muita acuidade, às psicológicas, nomeadamente àquilo a que chama a «vida psíquica» no subtítulo da obra a que nos referimos. Segundo Cohn, essa «vida psíquica» emerge na literatura em duas variantes já de longa data reconhecidas como distintas: a narrativa na terceira pessoa e a narrativa na primeira pessoa (cf. Cohn 1981[1978]: 29). Para o caso que aqui nos importa, é a sua tipologia relativa à narrativa na terceira pessoa que essencialmente nos interessa. Devemos ainda registar que a proposta de Cohn não se ocupa da relação de todas as ocorrências a que podemos chamar voz, na narrativa. O seu campo restringe-se, como ela própria o acentua ao sumariar o seu trabalho, à relação da voz com a vida interior:

[...] Podemos distinguir três modos de representação da vida interior no contexto de uma narrativa na terceira pessoa; consagro a cada um deles um capítulo da minha primeira parte. Resumindo-os, temos: (1) a psico-narrativa, discurso do narrador sobre a vida interior da personagem; (2) monólogo relatado, discurso mental de uma personagem; (3) monólogo narrativizado, discurso mental de uma personagem assumido pelo discurso do narrador.(1981[1978]: 28-29)

Apresentado, assim, o quadro teórico que utilizaremos na observação dos textos que temos em vista, podemos avançar na nossa análise e no comentário crítico das análises já feitas que temos em consideração.

${ }^{6}$ «In sum, the narrated monologue is at once a more complex and a more flexible technique for rendering consciousness than the rival techniques. Both its dubious attribution of language to the figural mind, and its fusion of narratorial and figural language charge it with ambiguity, give it a quality of now-you-see-it, now-you-don't that exerts a special fascination» (1978: 107). E este monólogo assim entendido, sendo mais complexo e mais flexível por manter a incerteza quanto à atribuição do discurso, ou à personagem ou ao autor, abre um espaço de exploração aleatório, mas criativo ao crítico que o aborda e pretende, dele, tirar as máximas consequências hermenêuticas: «Even dry scholars wax poetical when they describe its effects» (Cohn 1978: 107), efeito que, reconhecemos, igualmente nos toca.

${ }^{7}$ Sabemos que isso não é fácil na adaptação de uma narrativa verbal deste tipo. Um fracasso semelhante teve, há décadas, Martin Ritt, que nem era um realizador «de serviço», sendo, por muitos críticos, considerado um verdadeiro autor, ao tentar adaptar The Sound and the Fury, obra suprema de Faulkner, como é consenso mais ou menos generalizado dos críticos e estudiosos da sua obra. 
lização objectiva, quase documental, embora se perceba, desde os primeiros momentos, que essa visualização, não obstante ter alguns contornos objectivos, se revela, a pouco e pouco, altamente perturbada, abusivamente intromissiva, ao ponto de ser o acto quase patologicamente escoptófilo. Esse voyeurismo, além de alimentar uma atitude imaginativa, perto do sonho ou mesmo do delírio, à personagem autodiegética de Rachel, é um devaneio que vem intensificar a sua vontade de espreitar, espiolhar, ao ponto de se ampliar alimentando-se de todas as fontes sensoriais a que acede.

Se, por um lado, o delírio de Rachel pode ser considerado meramente especulativo, deambulante e errático, em torno do sistema dinâmico central da sua perturbação emocional, cujas razões já foram aludidas acima, por outro ele torna-se um procedimento de investigação dos indícios que esta narradora vai captando ao longo das suas travessias e, sobretudo, dos quadros que sucessiva e repetidamente se vão apresentando através da janela do comboio.

O termo usado por Paula Hawkins para o processo de visionamento de Rachel é rubbernecking ${ }^{8}$ (cf. Hawkins 2018: 104; trad. port, 2017: 85), ou seja, torcer o pescoço para olhar, sob impulso de uma tara, um acontecimento chocante. Muitas vezes são os condutores que abrandam, para observarem melhor os acidentes cujo aparato os fascina, noutras, como é o caso com Rachel, é o semáforo vermelho (um quase instrumento do destino, ou fatalidade, a que voltaremos a referir-nos) que obriga o comboio a parar exactamente no ponto da linha férrea de onde melhor se avistam as traseiras das vivendas entre as quais se encontra o lar em que viveu com o marido. Tê-lo perdido e ver, nesse seu espaço íntimo, agora, imagens da existência do ex-cônjuge, da nova mulher, e da filha de ambos, ainda bebé, é a mais terrível imagem de desastre que a rapariga no comboio pode ter. $\mathrm{E}$ é nesse lugar outrora seu, e nos espaços circundantes, que o olhar de Rachel se fixa e a sua imaginação, intensificada pelo alcoolismo, labora.

\footnotetext{
${ }^{8}$ Literalmente, o termo significa esticar ou torcer o pescoço (como se ele fosse de borracha). Mas tem o sentido, por conotação cultural da vida moderna (no slang, talvez de origem londrina, já muito generalizado no falar popular das cidades onde se fala inglês), de ter um pescoço muito maleável, para olhar para o lado, e designa, depreciativamente, o olhar mórbido que algumas pessoas lançam, do interior dos veículos em movimento, sobre acontecimentos catastróficos, especialmente desastres de trânsito ocorridos nas vias que percorrem, ou em locais com os quais se cruzam os meios de transporte em que se deslocam. A versão portuguesa que usámos não traduz o termo na sua complexidade, limitando-se a usar o termo «tarada».

${ }^{9} \mathrm{O}$ termo usado pelo tradutor como equivalente a rubbernecker é tarada. Está parcialmente correcto, mas falta-lhe o sema fundamental: «mirone».
} 
Vê, na casa ao lado, um casal de belo aspecto físico, que considera a viverem uma intensa felicidade conjugal. Gosta tanto da imagem em torno da qual deixa prolongar-se a sua imaginação, que lhes atribui nomes: Jason e Jess. É a sua coscuvilhice, semi-imaginada (sabe, deles, coisas que não correspondem à realidade), que nasce o seu apego, quase mórbido, aos factos que observa ou que, posteriormente, sabe pelos jornais. Numa das ocasiões, vê a jovem, que julgava em idílico convívio com o marido, na mesma varanda em que aparecia com ele, abraçada a outro homem, talvez mais belo e fascinante do que o companheiro legítimo. De imediato labora, a partir de incertezas, uma triangulação culposa. Mas como fascinante coincidência, acontece que um dia lê nos jornais que a jovem que via do comboio foi dada como desaparecida.

É pelo facto de sobre ela ter fixado a sua curiosidade mórbida que a notícia a atinge. Mas não só. Uma atitude sua, anterior, da qual não se lembra mas que lhe provoca um pressentimento, introduz-lhe um traço mnésico enigmático. Sem saber porquê o seu discorrer consciente relaciona um mal-estar emocional, sem imagens ou designações concretas, com a data presumível do acontecimento e o local das vivendas onde outrora morara, como que uma remota inquietação ligada a factos que pressentia, mas não conseguia recordar efectivamente.

É em torno da sua bisbilhotice, da sua atracção mórbida pelo local e pelos vazios de consciência que o estado de quase constante embriaguez lhe provoca, que a sua investigação prossegue. São essas memórias erráticas, em torno local onde outrora residira, que a tornam insegura quanto às sequências temporais de acontecimentos que recorda apenas como imagens desconexas. Do ponto fundo da sua descida, inicia uma anábase que a elevará até à inteligibilidade dos cenários e das circunstâncias em que é revelado um crime. É como se o álcool das bebidas que toma, sobretudo vinho e gin tónico, lhe activassem as capacidades de comunhão com as regiões mais enigmáticas e ocultas das consciências, com as quais se cruza, levando-a a aproximar-se da verdade, numa espécie de «elo místico» com os outros e romper com a sua «condição de angústia» (cf. Durand 1984: 297-298). Realizar a descida segundo Bachelard (apud Durand 1984: 227), é «desaprender o medo» dado que a «imaginação da descida precisa de mais precauções do que a da subida [...] porque a descida corre o risco, permanentemente, de gerar confusão e transformar-se em queda» (ibidem).

No entanto, uma vez atingido o objecto da demanda, alcançado o espaço já sem continuidade, como acontece quando Rachel redescobre o universo onde projectava todos os seus sonhos de felicidade, ela deixa-se arrastar pela tentação 
de «retorno triunfal e definitivo» (idem: 320) próprio da vontade de ascensão. Os seus trabalhos de investigação, no terreno do real e na sua vida interior, poderiam ser vistos como uma maiêutica, com a qual consegue atingir as reminiscências que intuía como vazios e enigmas.

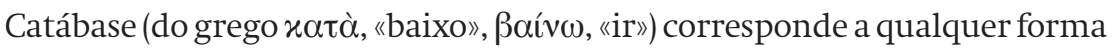
de penetração ou descida para um ponto central estabelecido como objectivo. Porém, na mitologia o termo é usado para se referir à ida ao mundo inferior (mundo dos mortos). Várias personagens na literatura, como Ulisses/Odisseu, Eneias, Aquiles, da épica antiga percorreram o declive para os infernos. Também Orfeu, o poeta mítico, segundo a apresentação que dele é feita por Ovídio nas Metamorfoses, aí foi, para tentar resgatar Eurídice. Mesmo Dante, entidade-poeta autodiegética, na obra Divina Comédia, é encaminhado, na descida às regiões subterrâneas, pela mão de outro poeta, ficcionado: Virgílio. Para Rachel essa descida aproxima-se muito do que Jung vê, na aproximação dos abismos, enquanto representação cultural da descida às regiões do inconsciente, fascinação que "aparece como um convite a explorar as profundidades da alma, ou libertar, nela, os fantasmas ou desfazer os enleios» (Chevalier/Gheerbrant 1982: $2^{10}$ ).

Quanto à ligação necessária entre a catábase e anábase, o poema de Dante é fulcral porque, tal como se desenvolveu no lastro mítico fundador da nossa cultura, no percurso catabático o herói descia, em geral, ao mundo dos mortos, com o propósito de os consultar, a fim de obter conhecimento. A verdadeira catábase deve ser seguida de uma anábase (ou o movimento de saída do mundo dos mortos), pois do contrário passa a tratar-se de morte, e não genuína catábase, como acontece com Megan. «A subida» no sentido que a esfera simbólica acima referida propõe é, em última instância, uma interiorização», valorização do que se adquiriu na «descida», que é, anteriormente, uma demanda e» dissipação no mundo exterior» (Chevalier/Gheerbrant 1982: 650"11).

No entanto no que se refere a Rachel, não menos nos pareceriam oportunas, quanto a esta questão, as intervenções de Baudelaire:

certaines boissons contiennent la faculté d'augmenter outre mesure la personnalité de l'être pensant, et de créer, pour ainsi dire, une troisième personne, opération mystique, où l'homme naturel et le vin, le dieu animal et le dieu végétal,

\footnotetext{
${ }^{10}$ Entrada: Abîme.

${ }^{11}$ Entrada: Montée.
} 
jouent le rôle du Père et du Fils dans la Trinité; ils engendrent un Saint-Esprit, qui est l'homme supérieur, lequel procède également des deux.

[algumas bebidas têm a faculdade de aumentar para lá das marcas a personalidade do ser pensando e criar, por assim dizer, uma terceira pessoa, operação mística, onde o homem natural e o vinho, o deus animal e o deus vegetal, assumem o papel do Pai e o Filho na Trindade; e engendram um Espírito Santo, que é o homem superior, que também procede de ambos.] (1972: 39) ${ }^{12}$

A capacidade de proceder ao duplo percurso para obter a verdade sobre a causa da morte, da mulher que vislumbrou do comboio e sobre a qual empreendeu um recorte narrativo imaginário ficcionalizado num modelo de vivência doméstica quotidiana, depende da sua utilização da bebida, repartida entre os efeitos inebriadores e reveladores, ora veneno disfórico, ora ambrosia, elixir da inteligibilidade e da conquista das reminiscências.

Por outro lado, a actuação de Rachel, redunda num acto de justiça, para o qual é como que arrastada pelas forças do destino e do acaso, em grande parte em resultado do seu deambular errático, sob o efeito do álcool. Movendo-se como justiceira e redentora, ela assemelha-se a Nemesis a deusa do panteão grego que personifica o destino, equilíbrio e vingança divina, traçada como fatalidade. Também aqui, Paula Hawkins se revela lídima herdeira da sua compatriota,

${ }^{12}$ «Le vin du solitaire

Le regard singulier d'une femme galante/Qui se glisse vers nous comme le rayon blanc/Que la lune onduleuse envoie au lac tremblant,/Quand elle y veut baigner sa beauté nonchalante;/ Le dernier sac d'écus dans les doigts d'un joueur;/Un baiser libertin de la maigre Adeline;/ Les sons d'une musique énervante et câline,/Semblable au cri lointain de l'humaine douleur,/Tout cela ne vaut pas, ô bouteille profonde,/Les baumes pénétrants que ta panse féconde/ Garde au coeur altéré du poète pieux;/Tu lui verses l'espoir, la jeunesse et la vie,/- Et l'orgueil, ce trésor de toute gueuserie,/Qui nous rend triomphants et semblables aux Dieux ! Les Feures du Mal (1972)

['O misterioso olhar de uma mulher galante/,Pousado sobre nós como um pálido raio/Que a lua envia ao lago em trêmulo desmaio,/Quando ali quer banhar sua beleza ondeante /A derradeira moeda à mão de um jogador;/Um beijo libertino da esguia Adelina;/Os sons ociosos de uma música ferina,/Que lembra ao longe a humana súplica da dor;/Isso tudo não vale, ó garrafa profunda,/O bálsamo que aflora em teu ventre e fecunda/O coração do poeta em júbilo ante os céus;/Tu lhe dás a esperança, a juventude, a vida/E o orgulho, essa riqueza aos pobres concedida,/Que os torna heroicos e mais próximos de Deus!' Tradução de Ivan Junqueira (Baudelaire 2006: 194-195)]».

Salvaguardando as diferenças de género, este poema bem podia ser a insígnia de Rachel, no final da sua penosa ascese. 
Agatha Christie, que plasmou no sistema ficcional da literatura policial de investigação, essa dimensão mítica do detective, do que busca resolver o mistério do crime, como um braço actuante da vontade de justiça dos deuses, dando o nome da deusa a um dos livros que tem como detective a solteirona metediça.

Resta acrescentar, para uma melhor compreensão deste discurso autodiegético de Rachel, revelador do seu percurso de busca ou demanda, o modo como funcionam, a estrutura-lo, ou mesmo a sustentá-lo, os outros discursos autodiegético e o procedimento de marcação, mise-en-scène e montagem da entidade autoral implícita.

Uma primeira observação que terá de ser feita, é a relativa ao sistema de montagem praticado pela indexação autoral através das didascálias, que comandam a ordem temporal das narrativas, apresentando os momentos do dia indicados dentro do registo, num patamar mais geral, dos dias, meses e anos em que os discursos ocorrem. Muitas vezes, um discurso de data anterior, sobretudo os de Megan, queé a personagem inicialmente percepcionada e idealizada por Rachel, é apresentado no desenvolvimento do discurso romanesco posteriormente, o que produz efeitos de analepses mais típicos do cinema do que do romance. $\mathrm{O}$ uso, em narrativa verbal, é menos comum, mas tem, também em Faulkner, de The Sound and the Fury, o seu antepassado ilustre (o discurso caótico de Benjy é muito posterior ao do seu irmão Quentin, segue imediatamente, 24 horas depois, o do seu irmão Jason, e só é procedido pelo do narrador autoral, altamente focalizado através uma serviçal negra de semblante e postura matriarcais).

É claro que isso dá um domínio autoral à sequencialidade que se torna mais poderoso e questionável do que no caso de se manifestar uma voz autoral evidente, plenamente omnisciente e extradiegética. A sequencialidade, na aparência, não é atribuível a nenhuma entidade discernível, mesmo uma que possa ser reconhecida como omnisciente. A distribuição das vozes, ao longo de uma ordem aparenta a acção uma vontade tão arbitrária, ocasional e irreprimível, como a que poderíamos atribuir ao destino ou a uma potestade imprevisível e desconhecida.

No entanto, o efeito semântico, ou seja, de produção de sentido, que dessa montagem resulta, é muito bem-vindo. Ao discursar caótico e, por vezes, enigmático ou elíptico de Rachel, vêm interpor-se discursos que, como que arrastados por uma suprema vontade de ordem, esclarecem algumas obscuridades e colmatam algumas lacunas. Mas nem todas e completamente, de uma vez. Essas vozes de Megan e de Anna apenas iluminam, ao sabor de um jogo de ocultação e desvelamento, algumas partes dos enigmas, dos «oráculos», das suspeitas e dos 
pressentimentos que atormentam Rachel. Por vezes funcionam como uma montagem alternada, revelando o que acontecia, ao mesmo tempo, a duas narradoras e às personagens referidas nos seus discursos. Outras, porém, funcionam como montagens paralelas, pondo em confronto, equivalência, contraste ou similitude, as personagens entre si, narradoras ou não.

A própria escolha de Rachel, nos seus modos e arremedos, disfarça, sobe a capa de uma casualidade e despreocupação, a construção de um desígnio que é, no fundo, a tecedura (e a tessitura, num jogo de diapasões) do enredo que vai sendo construído como urdidura de insondáveis instâncias a que apenas podemos dar nomes como acaso, acidente destino ou mesmo arbítrio. Mas, se a dinâmica das deslocações e as forças de atracção magnéticas que juntam e afastam personagens num mecanismo de diálogos mais ou menos discordantes, sinais e posturas de equívocos sentidos, podem parecer, confusa, a verdade é que ela se assemelha muito ao dispositivo dos tropismos de que fala Nathalie Sarraute, que quanto a este ponto nos pode fornecer um apoio:

São movimentos indefiníveis que deslizam rapidamente nos limites da nossa consciência; estão na origem dos nossos gestos, das nossas palavras, dos sentimentos que manifestamos, que acreditamos experimentar, e que são passíveis de definição. Pareciam-me e parecem-me, ainda, a fonte secreta da nossa existência. (1956: 8)

Esta característica básica fundamental, no discorrer que promove, é a linha condutora que levará Rachel à descoberta do criminoso e lhe dará, seguidamente, o ânimo fundamental para exercer a sua missão de Nemesis, mecanismo maiêutico que transparece com clareza exemplar no relato autodiegético de protagonista/detective, datado entre o domingo 4 de Agosto e quarta-feira 7 Agosto de 2013, (Hawkins, 2018: 236-2018) no qual se acumulam o máximo do efeito do discurso interior, segundo o modelo da corrente de consciência, os diálogos que sustenta com os interlocutores, um deles psiquiatra, e a análise dos sonhos que a assolam e que, tentando recordá-los, lhe acrescentam peças para a composição do puzzle que lhe virá a dar a imagem espantosa do acontecimento tal como se revela na resolução do mistério.

O facto de estarmos a lidar com uma narrativa de suspense, com um mistério que apenas se desvela em toda a sua dimensão no final da história nos últimos discursos das três narradoras, levou-nos à máxima cautela no comentário das motivações interesseiras, apreciação das acções psicopatológicas e mesmo 
na emissão de juízos ético-avaliativos que, de facto, constituem a dimensão configuracional da história ou fábula construída. Tratando-se de um tipo de thriller caracteristicamente integrável na categoria de whodunit, embora com alguns aspectos, apenas, de romance criminal (cf. Symons 1992: 201-208), ou seja, colocado na perspectiva das personagens fora-da-lei ou mesmo marginais, ${ }^{13}$ é conveniente respeitar, no acto crítico, o mistério principal que conduz à revelação do culpado ou dos culpados e ao desfecho da intriga elaborada.

Assim, antes de darmos por concluída a nossa análise, parece-nos de toda a pertinência deixar algumas palavras sobre a dimensão ético-avaliativa e ideológica da fábula, construída ao longo de todo o desenrolar da trama. E, para começar, convém sublinhar, com o que, em alguns pontos da nossa análise, já deixávamos transparecer, que a dinâmica conflitual estruturante de toda a acção assenta na valorização, questionamento e apreciação dos laços familiares, sobretudo maritais. Dois maridos de três esposas constituem estruturas passionais de latente apelo à violência, nomeadamente a doméstica. É nesse cadinho de desejos, ligações amorosas por vezes valorizadas mas, outras vezes, corrompidas ou desdenhadas, que a urdidura dos confrontos nasce e se desenvolve. No fundo, está sempre em causa a viabilidade da vida doméstica, a sua fragilidade e mesmo a sua exposição aos actos mais cruéis e destrutivos.

Nesse aspecto, este romance, para lá dos seus libelos policiais e de mistério, retoma filões mais antigos e prestigiosos da narrativa europeia, nomeadamente inglesa, colocando a imagem dos eixos e impulsos sociais do poder e do domínio nas suas fontes primordiais, desde que foram constituídas as complexas redes das sociedades humanas: os poderes parentais, o domínio do espaço doméstico e a tensão erótico-afectiva que fundam a distribuição e hierarquia no conjunto familiar, temáticas que, de um modo geral, desde o romance gótico

\footnotetext{
${ }^{13}$ Referimo-nos, obviamente, a uma variante de histórias envolvendo actos violentos condenáveis pelas leis e costumes, mas apresentados, em grande parte, segundo a focalização da mente criminosa. Um grande clássico poderia ser Crime e Castigo (em russo, cirílico: Преступле' ние и наказа'ние; em carateres romanos: Prestuplênie i nakazánie) de Fiódor Dostoiévski. A narrativa modelar que marcou a cultura ocidental mais actual, dentro do género criminal, poderia ser a série romanesca de Patricia Highsmith chamada The «Ripliad»: The Talented Mr. Ripley (1955)/O Talentoso Mr. Ripley (2013), Ripley Under Ground (1970)/Ripley Subterrâneo (2004-Br) Ripley's Game (1974)/O Amigo Americano (2016), The Boy Who Followed Ripley (1980)/O Rapaz Que Seguiu Ripley (2017) e Ripley Under Water (1991)/Ripley Debaixo de Água (2003); ou ainda, para lembrar a narrativa cinematográfica, Strangers on a Train (O Desconhecido do Norte - Expresso) de Alfred Hitchcock, de 1951 adaptação do primeiro romance da mesma Patricia Highsmith, de 1950, como mesmo nome, sendo o título da tradução portuguesa conforme ao que foi dado filme.
} 
e mesmo da narrativa romântica e realista, têm sido dominantes, pelo menos nas expressões mítico-fabulatórias da cultura ocidental.

\section{Bibliografia}

BAUDELAIRE, Charles (1972), Les paradis artificiels, Paris, LGF/Le Livre de Poche. (1972), Les Fleurs du Mal, Paris, Gallimard/Poésie. (2006), Poesia e Prosa, Rio de Janeiro, Nova Aguilar.

BOOTH, Wayne C. (1980), A Retórica da Ficção, Lisboa, Arcádia.

CHEVALIER, Jean/ Alain Gheerbrant (1982), Dictionnaire des symboles, Paris, Robert Laffont Édition.

COHN, Dorrit, (1978), Transparent Minds, Narrative Modes for Presenting Consciousness in Fiction, Princeton, New Jersey, Princeton University Press. (1981), La Transparence Intérieure. Modes de représentation de la vie psychique dans le roman, Paris, Seuil.

DURAND, Gilbert (1984), Les structures anthropologiques de l'imaginaire, Paris, Dunod/Bordas. HAWKINS, Paula (2018), The Girl on the Train, London, Black Swan (reedição). (2017), A Rapariga no Comboio, Lisboa, Topseller.

SARRAUTE, Nathalie (1964), L'ère du soupçon, Paris, Idées/NRF.

SILVA, V. M. de Aguiar e (1973), Teoria da Literatura, 3. ․ Edição, Almedina, Coimbra. SYMONS, Julian (1992), Bloody Murder, London, PAN Books. 


\section{«To Play a Fool»:}

\section{uma narrativa feminocêntrica por Laurie R. King}

Duarte Pinheiro

Universidade da Califórnia, Berkeley

Universidade Estadual de São José

«Reading mysteries is always a guilty pleasure, an act of negotiation with patriarchy» afirma Sharon A. Russell (apud Klein 1995: 43) no artigo «Gender and Voice in the Novels of Sarah Caudwell». Este ato de negociação com a patriarquia teve início em 1841, com Monsieur C. August Dupin, detetive criado por Edgan Allan Poe n'O Crime da Rua Morgue. Em 1878, Anna Katherine Green «became the first woman to write a detective novel and to create a female detective» (Amelia Buttherworth) [torna-se na primeira mulher a escrever um romance policial e a criar uma mulher detetive (Amelia Buttherworth)] (Lake 2006). No entanto, seguiram-se a Amelia Buttherworth, os canónicos Sherlock Homes (Sir Arthur Conan Doyle, Um Estudo em Vermelho, 1887), Padre Brown (G.K. Chesterton, A Cruz Azul, 1910), Hercule Poirot (Agatha Christie, A Primeira Investigação de Poirot [The Mysterious affair at Styles], 1920), Philip Marlowe (Raymond Chandler, The Big Sleep, 1939), George Smiley (John Le Carré, Call for Death, 1961), Adam Dalgliesh (P.D. James, Cover her Face, 1962), e mais recentemente, por exemplo, Hieronymous «Harry» Bosch (Michael Connelly, The Black Echo, 1992). Por conseguinte, de acordo com Kathleen Klein, «The predictable formula of detective fiction is based on a world whose sex/gender valuations reinforce male hegemony»(Klein 1995: 225). [A fórmula previsível da ficção policial baseia-se num mundo em que valores de género/sexo reforçam a hegemonia masculina]. Inspetores e detetives homens desde sempre abundaram nas narrativas policiais e mesmo durante a Idade de Ouro da ficção policial «Of the big five women writers of the Golden Age (Christie, Sayers, Tey, Marsh, and Allingham, only Agatha Christie created women detectives as the protagonists of her novels» (Klein 1995: 11). [Das cinco grandes escritoras da Idade de Ouro (Christie, Sayers, Tey, Marsh e Allingham), apenas Agatha Christie criou mulheres detetives como protagonistas]. Qual o espaço 
então da mulher detetive na história do romance policial? Que outras Amelia Buttherworth e Miss Marple foram protagonistas de narrativas policiais? A ficção policial foi sempre um mundo masculino, como observa Kathleen Klein, ou a tendência tem vindo a inverter-se nas últimas décadas? E se se confirmar esta conversão, até que ponto se pode rotular uma narrativa policial de «feminina»? A mulher detetive começa a ganhar maior protagonismo na década de 70 do século passado, precisamente num subgénero da ficção policial conotado com o universo masculino, o hard-boiled. Por universo masculino entenda-se não só a escolha de um homem como protagonista da narrativa, mas também uma série de comportamentos e valores masculinos validados pelo espaço sociocultural enquanto tais:

Since its beginnings, mystery fiction has valorized gendered texts. Its strong appeal to either rational solutions, painstankingly worked out through clues and logic, or physical action, traded in body blows and gun battles, stresses conventionally ascribed masculine virtues; women were assumed to be both less logical and weaker than men. The abstract appeal to justice in classical novels and the assumption of personal codes of action in the hard-boiled novels similarly aprove the lessons taught by the society as masculine. (Klein 1995: 11)

[Desde os seus primórdios, a ficção policial valorizou textos marcados por noções de género. A forte sedução por soluções racionais, diligentemente resultantes de pistas e lógica, ou por ação física como lutas ou confrontos armados, sublinha virtudes convencionalmente atribuídas aos homens; sendo as mulheres encaradas como menos lógicas e mais fracas do que os homens. A atração abstrata à justiça no romance clássico e a premissa de códigos individuais de ação no romance hard-boiled validam, de forma semelhante, os atributos designados pela sociedade como masculinos].

A autora responsável pela intensificação da escrita policial por parte de mulheres foi Sue Grafton, escritora estadunidense que, com a série alfabética de narrativas que tem Kinsey Millhone como investigadora, conferiu uma notoriedade à produção literária numa voz totalmente feminina. Na verdade, segundo Priscilla L. Walton e Manina Jones,

Successful in its own right, Grafton's both series participates in and is representative of a larger publishing phenomenon: the emergence of the female hard-boiled series detective. Since the late 1970s, this subgenre of the crime novel written by 
women and centering on the professional woman investigator, has virtually exploded onto the popular fiction market. (Walton/Jones 1999: 1)

[Os romances da série de Grafton, cada um deles com sucesso individual, participam e são paralelamente representativos de um fenómeno editorial mais alargado: o surgimento do romance hard-boiled feminino. Desde os fins dos anos setenta, este subgénero de narrativa policial produzida por mulheres e com protagonistas femininas, virtualmente explodiu no mercado da ficção narrativa].

Com efeito, a partir de A is for Alibi (1982) de Grafton, outras narrativas escritas por autoras assumiram protagonismo no seio da ficção policial. A mulher enquanto investigadora sai da sombra do detetive homem e veste papéis que desafiam o que era convencionalmente lido e aceite. O romance policial per se não se limita então ao mero enredo de uma investigação criminal, mas passa a abordar temas como a desigualdade de género, a exclusão social, a religião (...). Neste sentido, a década de 80 é um período rico na produção deste tipo de narrativas. Kate Delafield incorpora bem esta ideia, uma detetive da polícia de Los Angeles, lésbica, veterana do Vietnam, uma loba solitária criada pela américo-canadiana Katherine Forrest. Kate Delafield não é representativa do primeiro caso de amor lésbico numa narrativa policial, pois esse pertence, como identifica Anthony Slide, ${ }^{1}$ a Death of a Doll, de Hilda Lawrence; mas Delafield é representativa das narrativas policiais da década oitenta que passam ocupar um espaço dentro da ficção policial, a narrativa policial lésbica.

É neste âmbito que Kate Martinelli nasce em 1992. Na verdade, a série «Kate Martinelli Mysteries», de Laurie R. King, exemplificam na perfeição o conceito de narrativa feminocêntrica criado por Linda Yeager e aperfeiçoado por Katherine Klein. De acordo com Klein, "A feminocentric novel does not necessarily need a feminist detective but it cannot evade questions of gender - interwined with those of class, race, sexual preference, and social attitudes - if it is to succeed; it must, in Carolyn Heilbrun words, deconstruct... the structures of the patriarchy». [Para ter sucesso, um romance feminocêntrico não requer necessariamente uma detetive, mas não pode deixar de abordar questões de género, interrelacionadas com as de classe, raça, sexualidade e comportamentos sociais; tem de, nas palavras de Carolyn Heilbrun, desconstruir... as estruturas patriarcais] (Klein 1995: 11).

\footnotetext{
${ }^{1}$ Nas palavras de Anthony Slide «Many mystery writers from the first half of the 20th century were far from explicit in identifying their gay or lesbian characters. Without resorting to stereotypes it was possible to label a woman as 'lesbian' as with the 1947 novel Death of a Doll by Hilda Lawrence» (Slide 1993: 5).
} 
Laurie Richards King, nascida em 1952, em Oakland (Califórnia), é autora de 27 romances policiais. Licenciada em Religião Comparada pela Universidade de Berkeley, Califórnia, com a tese «The Holy Fool», obteve o grau de mestrado em Teologia em 1984, com a dissertação «Feminine Aspects of God», tendo recebido ainda um doutoramento honoris causa pela Church Divinity School of the Pacific (UC Berkeley) em 1997. Detentora de vários prémios literários, e mais reconhecida pela «The Mary Russel Series», o romance de estreia de King A Grave Talent (1993) tem, porém, como protagonista Kate Martinelli. Martinelli é personagem principal em cinco narrativas, mas é o segundo romance desta série - To Play the Fool -, publicado em 1995, o objeto de estudo deste artigo. Em concomitância, To Play the Fool é a narrativa mais autobiográfica de Laurie R. King e uma das que mais se adequa ao conceito enunciado por Klein.

To Play the Fool (Fazer-se de Louco), título inspirado na peça shakesperiana Noite de Reis, narra a investigação do assassinato de um mendigo, John Doe, ${ }^{2}$ na cidade de São Francisco. A narrativa abre com o crematório do cão desse mendigo, Teophilus. ${ }^{3}$ A cerimónia fúnebre tem lugar no Golden Gate Park e é conduzida por Brother Erasmus ${ }^{4}$ (Irmão Erasmo), um pregador; todos os mendigos próximos de John Doe assistem à mesma. São esses, à exceção do Irmão Erasmo, que três semanas mais tarde cremarão o cadáver de John Doe. O crime é investigado por Al Hawkin e Kate Martinelli, uma dupla da brigada de homicídios da polícia de São Francisco, formada aquando da investigação do assassinato de três crianças em A Grave Talent. No primeiro romance de Laurie King, Al Hawkin, prestes a conhecer Kate Martinelli e em conversa com um colega, dá voz a um estereótipo machista recorrente na polícia de São Francisco:

\footnotetext{
${ }^{2}$ John Doe e Jane Doe são nomes atribuídos pelas autoridades americanas a identidades desconhecidas. Além disso, os tribunais americanos também permitem o uso destes nomes para preservar a identidade das pessoas em determinados casos. O uso consentido legal de «John Doe» teve origem na Inglaterra durante o reinado de Eduardo III, no século XIV (Quinion 2003).

${ }^{3} \mathrm{O}$ cão Teophilus é uma possível referência bíblica. Teófilo - do Grego $\Theta \varepsilon \circ \phi i \lambda o \varsigma$, deriva de $\theta \varepsilon \circ \varsigma$ (theos) «deus» e $\phi \iota \lambda o \varsigma$ (philos) «amigo» - é a pessoa a quem o Evangelho São Lucas e os Atos dos Apóstolos são dedicados. A referência a este "Amigo de Deus», atribuída a um cão (o melhor amigo do homem», não parece ser inocente em To Play the Fool, dado que é a personagem da narrativa que mais reúne consenso na comunidade dos sem-abrigo de São Francisco.

${ }^{4}$ Brother Erasmus é uma clara referência a Erasmo de Roterdão (1466-1536) e à obra 0 Elogio da Loucura, como faz questão de notar a própria autora através da voz de Al Hawkin: «Erasmus was a philosopher, wasn't he? He wrote The Praise of the Folly. Seventeenth Century? Sixteeenth?» (King 2014: 13).
} 
publicou o seu primeiro romance A grave talent, Laurie R. King já tinha escrito porém duas narrativas, que tinham como protagonista Mary Russell, uma investigadora nascida em 1900. Kate Martinelli nasce assim da implausibilidade de Mary Russell investigar crimes correntes, mas é uma personagem verosímil, pela autenticidade da personagem em si. Kate não preenche qualquer estereótipo, quer social quer ficcional, afirmando-se como uma mulher forte, reservada, que expõe pouco a usa vida privada, e notabilizando-se por ser uma polícia competente, experiente e determinada. Kate Martinelli veste assim o protótipo da personagem feminocêntrica, distinta das demais pela plausibilidade a um mundo real:

In the cast of characters, representations of women should be replaced with a wide range of plausible women. The excuse of familiar stereotypes for formula fiction does not serve the needs of feminocentric detective novels. The partial, narrow, and restricted view of "woman» drawn from nostalgic myths and sentimental images which influenced the genre's creation of murderers, victims, and detectives is not suficient; real women are portraying authentic, lived experience are necessary. (Klein 1995: 228)

[No elenco de personagens, representações do feminino deveriam ser substituídas por uma panóplia de mulheres plausíveis. A utilização de estereótipos familiares enquanto fórmula ficcional não corresponde aos requisitos dos romances policiais feminocêntricos. A visão parcial, redutora e limitada da «mulher», desenvolvida por mitos nostálgicos e imagens sentimentais que influenciaram o género na criação de assassinos, vítimas e detetives, não é suficiente; são necessárias mulheres plausíveis que retratem autenticidade e experiências de vida].

Na verdade, e à semelhança de Kate, há outras mulheres plausíveis em To Play The Fool, que têm um desempenho fulcral na narrativa e desenrolar da história. Beatrice Jankowski ${ }^{5}$ é uma delas. Beatrice é uma sem-abrigo, idosa, que sobrevive nas ruas de São Francisco graças ao talento artístico; às sextas-feiras à noite frequenta um café na Haight Street e cobra aos transeuntes para fazer os seus retratos. Esta mulher artista está, porém, na lista de suspeitos que poten-

\footnotetext{
${ }^{5} \mathrm{O}$ apelido polaco «Jankowski» atribuído a Beatrice poderá ter tido origem no polémico padre Henryk Jankowski (1936-2010). Jankowski foi um dos principais apoiantes do movimento de Solidariedade de Lech Walesa em oposição ao governo comunista da década de 1980, em poder na Polónia. Instrumental para o fim do regime comunista na Polónia, a reputação de Jankowski viria ser manchada devido a acusações de pedofilia e declarações antissemitas (New York Times, 2010: A25).
} 
cialmente teriam assassinado John Doe. Essa lista contém ainda os nomes de outros sem-abrigo, tais como, Harry Radovich, Richard Delgado (apelidado de «Mouse»), Luis Ortiz, Wilhemena, Doc, Salvatore Benito. ${ }^{6}$ É pela voz de Beatrice que o principal suspeito é identificado, Brother Erasmus. Segundo Beatrice Jankowski, num diálogo inicial com Kate e Al, Brother Erasmus teria sido alvo de chantagem por parte de John Doe. Esta confissão leva a dupla a suspeitar de Brother Erasmus, cuja atividade profissional e comportamento têm grande destaque na narrativa. Será uma outra mulher, a Professora Eve Whitlaw, que revelará o passado de Brother Erasmus. Cabe ainda a esta investigadora e professora visitante da UC Berkeley a narração sobre o movimento dos Holy Fools (Loucos por Cristo), que afirma «for a true Fool, a Holy Fool, madness is always simulated. It is a tool, not a permanent state. (...) That's why a fool is so troubling; he's a mirror, and mirrors can be frightening». [Para o verdadeiro Louco, o Louco por Cristo, a loucura é sempre simulada. É um instrumento, não um estado permanente (...). É por isso que o Louco é tão problemático; ele é um espelho e os espelhos podem ser assustadores] (King 2014: 135). Eve Whitlaw confere cientificidade às ações do Brother Erasmus, que, qual São Francisco de Assis, se despoja de materialismos para se dedicar aos mais necessitados. Na verdade, a Professora Whitlaw é a voz do passado, pois é graças a ela que o leitor descobre a identidade de Brother Erasmus, David Sawyer. Colega de Whitlaw na universidade, David Sawyer sofre a perda da sua filha, que foi assassinada por uma das suas alunas. Como forma de penitência - pois sente-se culpado pela morte da filha - torna-se um louco por Cristo. A narrativa To Play a Fool gira em torno do principal suspeito e do movimento dos Loucos por Cristo, mas Eve Whitlaw levanta as dúvidas sobre o passado e inocência de Brother Erasmus. Quem terá matado John Doe?

Antes de respondermos a esta pergunta, centremo-nos numa outra personagem não menos importante para o desenrolar da história, Lee. Psicóloga de profissão, Lee é a principal interlocutora de Kate Martinelli. Se não é indesmentível que os diálogos de Kate com Al Hawkin desempenham uma importante função na história, também não é menos verdade que as conversas entre Kate e a parceira, Lee, são essenciais para que a investigação prossiga.É Lee, por exemplo, quem traça um perfil psicológico dos loucos por Cristo e, por conseguinte,

\footnotetext{
${ }^{6} \mathrm{~A}$ multiplicidade de apelidos demonstra bem a heterogeneidade étnico-racial da comunidade sem-abrigo da cidade de São Francisco.
} 
do principal suspeito - «It's a Jungian archetype, of course, a way of counteracting the tendency of social and religious groups to become concretized. The Trickster is a combination of subtle wisdom and profound stupidity, a person both divine and animalistic» [Claro, é um arquétipo junguiano, uma forma de combater a tendência de grupos sociais e religiosos de se consolidarem. O Trickster é uma combinação entre conhecimento súbtil e profunda estupidez, uma pessoa divina e, ao mesmo tempo, animalesca] (King 2014: 68). Lee é a outra face da moeda de Kate, aquela que mantém o equilíbrio emocional da detetive de São Francisco e raciocina conjuntamente para resolução do caso. Lee é, por conseguinte, outra voz narrativa essencial no desenrolar do romance. Kate, Lee, Eve Whitlaw e Beatrice Jankowski são personagens que representam vários grupos sociais e profissionais e, também, vozes narrativas centrais em To Play the Fool, que, em conjunto, criam uma heteroglossia feminina sobre diversos temas e reflexões filosóficas. Esta heteroglossia de vozes narrativas femininas é um elemento indispensável num romance feminocêntrico como identifica Katherine Klein:

In addition, if women's stories are to be authentically told, they must be spoken in women's voices. It is obvious that the male first-narrator cannot truthfully tell a woman's story, but neither can an implicitly phallocentric third-person narrative voice which cleaves to the generic formula. Although the first-person woman narrator provides one alternative, even more productive is what Joanne Frye calls "community». When not only the single voice of the narrator but also the single image of the heroic detective are diffused, the many voices of women in the novels - their heteroglossia, if you will - can emerge. In rejecting the monolithic world view of patriarchy and the narrative imperatives of the genre, this feminocentric detective fiction replace received attitudes with open-ended diversity. (Klein 1995: 228-229)

[Adicionalmente, se queremos que as histórias de mulheres sejam autenticamente narradas, estas têm de ser feitas por vozes femininas. É óbvio que um narrador autodiegético masculino não pode narrar verdadeiramente a história de uma mulher; o mesmo acontece com a voz de um narrador na terceira pessoa implicitamente falocêntrico, que permanece cativo à fórmula genérica. Embora uma narradora em primeira pessoa seja uma alternativa, mais produtiva é o que Joanne Frye apelida de «comunidade». Quando não só a voz da narradora mas também a imagem da detetive heroína se difundem nas muitas vozes femininas no romance, a heteroglossia, se assim lhe requemos chamar, emerge. Ao rejeitar a visão patriarcal monolítica e os imperativos narrativos do género, esta ficção policial feminocêntrica substitui parâmetros pré-concebidos por diversidade ilimitada.] 
Estas personagens encorajam os/as leitores/as a refletirem sobre o mundo que habitam. Se a personagem Brother Erasmus e a questão dos loucos por Cristo ocupam uma posição de destaque nesta história, também não é menos verdade que os sem-abrigo de Play the Fool são fonte e alvos de reflexão sobre temas como a desigualdade social, a pobreza, raça, sobrevivência. A cidade de São Francisco, nas palavras de David Fine e Paul Skenazy, «is city founded suddenly, destroyed just as suddenly - an instant city» [uma cidade fundada repentinamente e destruída de forma igual, uma cidade instantânea] (Fine/Skenazy 1995: 4) é um espaço paradoxalmente dividido entre riqueza e pobreza extremas. Numa população de 880.000 habitantes, 8011 são sem-abrigo, de acordo com os dados dos últimos censos veiculados na imprensa escrita, por exemplo, no San Francisco Chronicle (Fagan 2019). Apesar de ter sido escrito há mais de duas décadas, em 1995, To Play the Fool já alertava para este flagelo social e díspar na distribuição de riqueza. A história de vida de Beatrice Jankowski é um retrato verosímil da condição dos sem-abrigo. Beatrice, qual John Doe, é assassinada à paulada. A morte de Beatrice revela, porém, uma realidade mais cruel, a da idade. Beatrice é representativa de uma faixa etária muito fragilizada e vulnerável da sociedade, visto que frequentemente os recursos são insuficientes para suportar os custos inerentes ao processo de envelhecimento, o que leva muitos destes anciãos a recorrerem à mendicidade. Subjaz assim a esta morte uma ideia explícita de exclusão social e, ao mesmo tempo, de perenidade ou perpetuação de uma identidade socialmente inexistente, a da sem-abrigo.

«I hadn't realized how old she was», Kate said bleakly.

«She had false teeth», commented the morgue attendant. «Taking them out makes anyone look shriveled up. His her family going to want her shipped, do you know?» I don't know if she had a family».

«We'll hang on her for a while, then». (King 2014: 216-217)

[Não me tinha apercebido de quão avançada fosse a sua idade», afirmou desoladamente Kate.

Ela usava dentadura, comentou o empregado da morgue. Tirá-la faz qualquer um parecer encovado. Sabe se a família dela vai querer que nós translademos o corpo? Não sei se ela tinha família.

Então, mantemos aqui o cadáver por algum tempo.]

Neste âmbito, To Play the Fool é feminocêntrica, pois «Foregrounding gender leads to questioning patriarchist assumptions through creating an interrogative 
interessado não tanto no crime quanto na condição humana. É esta leitura do mundo, através de um corpo e voz femininos, que King, num ato de sobriedade ou de loucura, propõe em To Play the Fool, um romance feminocêntrico.

\section{Bibliografia}

ANCONA, Francesco Aristide (1986), Writing the Absence of the Father: undoing Oedipal structures in the contemporary American novel, Lanham, University Press of America.

FAGAN, Kevin (2019), «SF population swells by 17\% latest tally», <https://www.sfchronicle. com/bayarea/article/SF-homeless-population-swells-by-17-in-latest-13851897.php> (último acesso em 18/06/2019).

FINE, David/ Skenazy, Paul (1995), San Francisco in Fiction: essays in a regional literature, Albuquerque, University of New Mexico Press.

KING, Laurie R. (1993), A Grave Talent, Nova Iorque, St. Martin's Press. (2014), To Play the Fool, Nova Iorque, Picador.

KLEIN, Kathleen Gregory (1995), The Woman Detective: Gender and Genre, Urbana, University of Illinois Press.

(ed.) (1995), Women Times Three: Writers, Detectives, Readers, Ohio, Bowling Green State University Popular Press.

LAKE, Lorie L. (2005), «The Gay Detective Novel», <http://www.lorillake.com/lesbiandetective.html> (último acesso em 14/06/2019).

New York Times (2010), «Henryk Jankowski, Pro-Solidarity Priest, Dies at 73», p. A25. <https:// www.nytimes.com/2010/07/14/world/europe/14jankowski.html?_r=1> (último acesso em 26/06/2019).

QUINION, Michael (2003), «John Doe», <http://www.worldwidewords.org/qa/qa-joh2.htm> (último acesso em 26/06/2019).

SLIDE, Anthony (1993), Gay and Lesbian Characters and Themes in Mystery Novels, a critical guide to over 500 works in English, Jefferson, North Caroline, and London, McFarland \& Company, Inc., Publishers.

WALTON, Priscilla/ Jones, Manina (1999), Detective Agency, Women Rewriting the Hard-Boiled Tradition, Berkeley, Los Angeles, London, University of California Press. 


\section{Apêndice \\ Entrevista a Laurie R. King}

\section{Esta entrevista teve lugar em Santa Cruz, Califórnia, no dia 14 de Junho de 2019}

DP: Katarina Cecilia Martinelli. Why an italo-american detective for your first novel?

LRK: I had written 2 Russell's books before publishing Kate Martinelli. I decided to write something more serious. I wanted to write about a modern woman Rembrandt. I wanted to have this artist who is a woman. A woman cop with a woman artist is more challenging. Then, considering the setting of the story, San Francisco as a big city makes more sense than a small village.

DP: How would you define Kate Martinelli?

LRK: Besides the obvious, lesbian, woman, cop, I would say she is a private person, a Californian, and very solid. When Kate commits herself to something she goes through. I've been working in a new novel with Kate Martinelli, which is coming in the Fall; she changed a lot.

DP: In an interview to Judith Markowitz you stated «As a defining part of who Kate is, her being a lesbian is nearly as important as the fact that she is a woman. And yet, the books are not about a lesbian, but about a woman cop who, among other things, happens to be a lesbian (Markovitz, 2004: 52). Would you consider gender discrimination and sexual discrimination main themes of all your narratives?

LRK: Yes. However, my books are not political, but rather «this is stupid, this should be fixed». They are more «conscious». Kate Martinelli herself would be interested in social protest. She is closeted less, because she doesn't want the attention intruding in her life. For instance, Katherine Forrest novels were more «lesbian lesbianess». They were marketed to a specific reading public. On the other hand, Kate Martinelli is not limited or directed to a specific public. If you are speaking to a specific audience you are limiting the authority of the book. For instance, in the books of Walter Mosley there is an African-American detec- 
tive (Easy Rawlins) who denounces social injustice regarding African-Americans, but his books are not limited only to the African-American readers. They achieve a wider audience.

DP: Do you consider «Kate Martinelli Series» lesbian police procedurals?

LRK: When I first wrote A Grave Talent, it never occurred to me that it was a crime novel, a police procedural. It was marketed as crime. If you put into a shelf, sure. I called «A Woman Mystery». I don’t mind to be categorized as «Mystery», because I get the mainstream of popular fiction.

DP: Kate Martinelli narratives have mainly a $3^{\text {rd }}$ voice narrator. However, in To Play the Fool there are several narrative voices that play essential roles in the investigation. For instance, Lee. Are the narrative voices of To Play the Fool mainly feminine?

LRK: I never took a writing class. All of my writing is story-telling rather self-conscious crafted narrative. I used a technique that it is really clever. Story-telling feels right for the story. I think it is more common a book interested in women to be about women ties and women community, not in the sole women. Mary Russell is a very solitary voice. She is an unbalanced person. On the other hand, Kate has a sense of community. It tends to be a set of women's voices. It comes more easily when you do a $3^{\text {rd }}$ voice narration.

DP: There is a process of personal growth of Kate along the series. The relationship between her and Al grows as well. However, she becomes more independent. For instance, in «Night Work» she is the only investigator. Is that independence a result of her growth?

LRK: In the San Francisco Police Department, for the most part, you have a partner in your team. She (Kate) becomes «steadier in her feet». I probably wanted her to run the show rather than him. It was less interesting having him as a boss. $\mathrm{Al}$ is not threatened by competent people. In A Grave Talent she is not a very interesting person... she becomes more comfortable with herself in the other narratives. She becomes more likeable as a person. She becomes more a community person.

DP: Only on «With Child» there's a reference to Kate's father. The closest masculine figure to Kate is $\mathrm{Al}$; and when he tries to be paternalist to her, she rejects him. 
LRK: Al is the only heterosexual male character. It is an interesting question. In the novella that I am publishing this Fall, called «Beginnings», I talk about Kate's past. The mother was a horrible character and the father doesn't exist.

DP: Is To Play the Fool the most autobiographical novel that you have written? LRK: It is my most autobiographical novel, although all the novels have something autobiographical.

DP: Is To Play the Fool a thesis-novel?

LRK: Sometimes madness is a sign of sanity. Brother Erasmus reappears later in a short-story. He is an attempt to show how to construct a personality from scratch. Does he gain an identity? He chooses that lifestyle as penitence. His ego leads to the other deaths. His goal is not to have that ego anymore.

DP: What happened in the Raven Morningstar case?

LRK: I might write a short-story about it at some point. The good thing about «series» is that each book is very independent. You don't really need to read the book before. To Play the Fool was a very interesting book to write. 



\section{Perspectivas femininas no policial suíço: Verena Wyss, Sabina Altermatt e Petra Ivanov}

Gonçalo Vilas-Boas

Universidade do Porto - ILC*

«Não faça troça dos romances policiais - são hoje o único meio para propagar ideias razoáveis», dizia a doutora Magde Lemoyne, personagem do romance Der Tee der drei alten Damen de Friedrich Glauser (1896-1938). Em carta ao Dr. Friedrich Witz de 25.3.1937, Glauser escreve: «A acção de um policial cabe em página e meia. O resto é um enchimento. Tudo depende do que se faz com esse enchimento. O interesse não está na trama, na descoberta do assassino, mas nas pessoas e sobretudo nos meios, nas 'atmosferas', onde elas se movem» (vd. Ott 2005: 38). Estas duas citações do mestre suíço da literatura policial, ainda hoje um marco essencial da produção policial da Suíça alemã, representam o enquadramento escolhido para este ensaio. Assim, focarei essencialmente os aspectos sócio-críticos do «enchimento», das «atmosferas» dos romances policiais de três autoras suíças contemporâneas. Como veremos, essas atmosferas são elementos simultaneamente culturais e simbólicos, contribuindo para que o espaço textual seja uma construção interpretativa do espaço real, incluindo a atribuição duma carga simbólica. ${ }^{1}$ Por razões óbvias, não entrarei em muitos pormenores da acção de detecção ou do desenrolar do próprio crime, para não desvendar pormenores que são importantes no prazer detectivesco do leitor.

\footnotetext{
* Este artigo foi escrito dentro das actividades da linha de investigação Inter/Transculturalidades do Instituto de Literatura Comparada Margarida Losa, Unidade I\&D financiada por Fundos Nacionais através da FCT - Fundação para a Ciência e para a Tecnologia (UIDP/00500/2020). O artigo não segue o último Acordo Ortográfico. Quando não indicado as traduções são de minha autoria.

${ }^{1}$ Utilizo aqui estes termos no sentido Miriam Llamas Ubieto (2012), nomeadamente nos subcapítulos «Órdenes simbólicos y processos subjectivos: concepciones modernas de la cultura» (pp. 26-30) e «Práticas simbólicas textuales: entre nível colectivo y nível subjectivo» (pp. 61-67).
} 


\section{Enquadramento teórico}

O tempo e o espaço da acção, inseridos nos respectivos contextos individuais e colectivos, estão situados em espaços que simbolizam a topografia e o tempo histórico reais, porém, a acção é sempre fictícia, ainda que se possa aproveitar de informações reais, veiculadas, por exemplo, por meios de comunicação sociais. A realidade é encenada em ficções, cuja autenticidade reside nela própria. A escritora suíça Eveline Hasler escreve: «Autores e autoras são sismógrafos do presente. [...] Os escritores tentam captar e analisar o presente fugidio. Tornar transparente as correntes subterrâneas» (Hasler 2007: 81). A autora fala ainda de «ambiente-tempo», que é preciso ter em conta (idem: 84), percebendo as estruturas sociais do tempo referidas no romance. Os espaços nunca podem ser apresentados holisticamente, são construções dos perspectivadores, sejam eles narradores ou personagens. "A realidade é afirmada pelo autor, mas esta é-nos transmitida por um acto criativo, literário» (Ott 2007: 101), tratando-se, portanto, de cartografias individuais que apontam para cartografias colectivas. Daí a importância de saber quem são e quais as perspectivas sobre a sociedade de cada um, sabendo que qualquer visão individual depende não só de valores racionais, mas também emocionais, porque cada indivíduo, quer na ficção quer na realidade, constrói a sua imagem do mundo em que se integra, direta ou indiretamente. Para além disso os espaços estão sempre em movimento, sobretudo nas séries romanescas.

O policial é essencialmente um discurso analítico, tendo em conta a análise dos processos de detecção, mas também dos crimes em si e dos contextos individuais e colectivos (cf. Marsch 2005). Neste aspecto, as linhas pessoais afastam-se, de um ou outro modo, do discurso analítico. Formalmente assistimos, como nota Jochen Vogt, a uma combinação do thriller com o romance policial, como uma variante do romance de crítica social, podendo essa amalgama ser maior ou menor (Vogt 2005: 45).

O espaço participa de modos distintos se nos encontramos numa cidade gigantesca, como Chicago, ou na Zurique de menor dimensão, ou ainda numa localidade com poucas centenas de habitantes, onde, muitas vezes, os assassinos se aparentam com o leitor, ou seja, não são grandes gangsters ou criminosos organizados, antes cidadãos normais que, por qualquer motivo, «descarrilaram». Na literatura suíça é frequente a utilização de pequenos espaços, incluindo deslocações desses espaços para cidades mais próximas, mas também há histórias 
nas grandes cidades do país, como Zurique, Basileia, Berna ou Genebra. Grandes redes criminosas são raras no policial helvético. Porém, como diz Zeindler, «o mal esconde-se por detrás de pessoas normais» (Zeindler 2005: 137) e vem à superfície, sub-repticiamente, a qualquer momento e em qualquer espaço.

A criminalidade é vista no romance policial moderno como uma das problemáticas intrínsecas à sociedade, com as suas próprias dimensões psicológicas, sociais e politicas. A realidade representada parece-se com um labirinto, exactamente como os caminhos e descaminhos dos investigadores. Cada crime representa sempre uma quebra duma linha de continuidade que importa restabelecer, sendo que o policial hoje representa sobretudo a análise das causas que estão por detrás do crime.

O labiríntico gera a resignação: na ficção policial em geral, a maior parte dos casos é resolvida; contudo, as causas da criminalidade não são afastadas, continuando a existir no mundo extratextual representado na ficção. Muitas vezes, os criminosos são vistos também como vítimas, daí dar-se importância aos contextos sociais e psicológicos que estão por trás do crime a ser investigado. Nesse processo, não é apenas o assassino que é criminalizado, mas também a sociedade.

De qualquer forma, num texto ficcional, as marcas espaciais extratextuais não dependem só da estratégia textual, mas, também, da maneira como o autor vê o mundo, a sua ideologia, entre outros factores. São, assim, construções perspectivadas, o que pode ser importante para a compreensão dos valores que transportam. Quanto à estratégia de leitura, estas marcas servem, também, para conferir credibilidade à acção, servem, afinal, para criar uma ilusão de real. «O ponto de vista determina a tomada de partido emocional do observador ou, mais precisamente, do leitor» (Mettler 2007: 89).

Para além da história da detecção nos seus aspectos progressivos e regressivos, o policial pode centrar-se noutras linhas narrativas, nas das relações pessoais das figuras, femininas no nosso caso, que não surgem desligadas da trama, sobretudo porque trazem uma grande carga emocional, que pode influenciar o lado mais racional da deteç̧ão (cf. Marsch 2005: 168-169).

Estes elementos intertextuais contribuem para a constituição de campos de referência e possibilitam aproximar o leitor do mundo textual. O leitor pode facilmente participar como detective, como portador de justiça: uma vez que ele acompanha o curso dos acontecimentos de forma distanciada, a partir da sua cadeira, pode comparar os valores em jogo com os seus e tomar posição. 
Os policiais femininos começaram a ter importância na Suíça sobretudo a partir da década de 90 . Ott regista, na sua história do policial suíço de 1990 até 2004, cerca de 25 novos nomes de autoras. E o número vai aumentando.

\section{Três autoras contemporâneas}

Neste espaço serão analisadas obras de três escritoras suíças de policiais, publicados no nosso século. Interessar-me-ão sobretudo os contextos sociais e os modos como são construídos, os «ambientes», como dizia Glauser, mais do que a acção em si, que obedece a determinados esquemas, recebendo dos contextos a sua própria especificidade helvética. Para tal escolhi três autoras de duas gerações diferentes; trata-se de uma escolha pessoal, pois muitas outras autoras poderiam também ter sido objecto de escolha. A primeira, Verena Wyss, nascida em 1945, a segunda, Sabina Altermatt, nascida em 1966 e a terceira, Petra Ivanov, nascida em 1967.

Verena Wyss (1945-) estudou História e História do Direito. Começou a escrever policiais já em 1994, centrando-se em questões ligadas ao mau funcionamento da justiça e muito em especial ao papel da mulher numa sociedade conservadora essencialmente patriarcal. Não se trata de uma série, mas de romances independentes: como o próprio título indica, o romance Die Untersuchungsrichterin (1994) [A juiz de instrução] baseia-se nas investigações de uma juiz de instrução criminal, sobre um caso de pesquisas genéticas eticamente reprováveis. Questiona-se sobretudo a diferença entre direito e justiça. O segundo romance, Verdecktes Spiel (1997) [Jogo escondido] segue a perspectiva de cinco mulheres, independentes umas das outras, mas que estão ligadas testemunhalmente a um mesmo crime. As cinco mulheres procuram os respectivos lugares na sociedade e só começam a resistir quando são atacadas nos seus direitos. Vários temas do livro reportam-se ao mundo actual: a corrupção de certos meios de informação, da indústria e do meio militar. Estes temas também aparecem nos três romances mais recentes: Todesformel (2008) [Fórmulas mortais], Blutrunen (2010) [Runas de sangue] e Föhnfieber (2012) [Febre do Föhn], os dois últimos com Pamela Thoma, psicóloga de formação, como protagonista. Nestes, a autora prefere narrativas na terceira pessoa, ainda que cedendo a perspectiva principal a Pamela. Os comentários estão centrados nas perspectivas das figuras nos respectivos diálogos. São romances lentos, com interrupções da linha de detecção, para, 
durante várias páginas, haver uma concentração nos problemas da protagonista. Este facto causa uma maior empatia do leitor, pela universalidade de muitos dos seus problemas e pelo estabelecimento de uma ligação mais pessoal com a protagonista.

Wyss quer mostrar o que se passa atrás da fachada de alguma alta finança mafiosa e antidemocrática. A própria autora refere o seu interesse pelos meios de comunicação social, pela ética da responsabilidade, quer individual, quer colectiva, de onde os sentimentos não podem estar ausentes e que será motora da acção. A pluriperspectividade permite dar uma visão múltipla dos mesmos factos: as portadoras das perspectivas, cada uma com a sua biografia singular, acabam por se tornar vítimas por questionarem e se revoltarem.

Vejamos então os dois últimos romances da autora. Em Blutrunen a jovem Pamela Thoma deixa o seu emprego numa empresa de publicidade, em Zurique, por razões meramente pessoais e também pelo cansaço face à grande cidade. Aceita ir trabalhar como bibliotecária no castelo de Château de Salms, na Suíça de língua francesa, um sítio com contornos idílicos. Começam a aparecer sinais estranhos, como um cadáver no cemitério, seguindo-se mais alguns assassinatos de difícil compreensão. Na biblioteca, Pamela descobre documentos secretos do tempo do nacional-socialismo, que comprometem quer autoridades da época, quer alguns movimentos do presente, nomeadamente grupúsculos neo-nazis e rituais celtas, a que estão ligados alguns membros bem situados na esfera política do país. Por um mero acaso, o comissário encarregado deste caso é um velho amigo de Pamela, o que faz com que ela seja integrada na equipa de detecção.

O leitor segue sobretudo a perspectiva da bibliotecária, que não tem qualquer habilitação no domínio da detecção policial, mas que tem uma grande capacidade intuitiva e analítica, o que lhe permite estabelecer relações não óbvias. A autora cria um ambiente muito pessoal, o que nos abre as portas a muitos aspectos que nada têm a ver com a investigação, mas apenas com a evolução da protagonista.

O romance segue duas linhas narrativas: a dos arquivos nazis e a de um grupo de delinquentes que, num dia de escola, no passado, tinham violentado uma rapariga com síndroma de Down. As linhas vão convergindo, pois os então miúdos estão agora ligados a rituais celtas, que, por sua vez, estão ligados a grupos neonazis com os nomes de SWASTIKA e ODESSA, grupos rivais com diferentes objectivos. Estamos face a vinganças pessoais e à justiça privada. Abor- 
dam-se temas presentes na Suíça, como noutros países ocidentais, nomeadamente questões que têm a ver com a justiça e a corrupção em diferentes níveis até à polícia (cf. BB: 353, 357-360), mas também temas mais gerais como a luta contra o cancro, a crise das vacas loucas, o negócio com cadáveres, o peditório para crianças na América do Sul, o aumento da relevância da extrema-direita, o desemprego.

Robert, o dono do castelo, diz:

É simples e não é simples: Tizian Füssli [membro da polícia em Berna] trabalha para a organização de Vincent [Professor em Zurique e irmão de Robert], Finn Weidenhuber [também da polícia] para a Associação Celta. Künzli, membro da Segurança Nacional trabalha para Weidenhuber. (BB: 360)

Föhnfieber está igualmente escrito à volta de Pamela Thoma, mas desta vez ela está em Berna, a tomar conta da casa da amiga Emily, entretanto nos EUA em tratamento do cancro, mas também do cão e sobretudo do filho Francis. Ela quer levar este adolescente a um jogo de futebol, mas vêem-se envolvidos numa grande e complexa rede de acontecimentos, tendo ela própria escapado por pouco. O pai de Francis, morto num acidente, tinha sido o arquitecto do estádio de Berna.

A pouco e pouco a acção centra-se no estádio: parece haver discrepâncias entre o plano original do arquitecto e a sua realização. A acompanhar a acção surgem textos em itálico da responsabilidade daquele que está encarregado de levar a cabo um enorme atentado no estádio durante um jogo importante. Ao mesmo tempo, e seguindo a estratégia da autora, vão aparecendo temas que ligam a acção à realidade suíça, como o terrorismo, a globalização, a corrupção. Pamela sente que há algo no ar na capital: «Berna, há algo que não bate certo. Passados alguns dias Pamela sente isso nos ossos, não por causa do Föhn e do sofá Futon, onde dorme» (FF: 12$){ }^{5}$

O romance segue três linhas narrativas diferentes, cada uma com uma focalização própria. Na primeira, temos Pamela e os polícias que conhecemos do romance anterior. Na segunda, temos Jossy e os seus diários. Ela é filha de um casal ligado à construção do estádio, que não recua perante o assassínio, para que não sejam descobertas algumas falcatruas. O casal pede à filha que siga de

\footnotetext{
${ }^{5} \mathrm{O}$ Föhn é um vento que sopra nos Alpes e causa mal-estar em muitas pessoas. É frequente aparecer na literatura suíça.
} 
perto Francis, o filho do arquitecto, uma vez que, como hacker, talvez conseguisse chegar a informações importantes para os pais relativas aos planos da construção do estádio. Aparentemente há corredores no estádio que não constam do plano do arquitecto: «Deverá haver corredores, que estariam nas mãos de terroristas e a segurança nada sabe da sua existência. Qual a razão desse segredo?» (FF: 216). Finalmente, seguimos a linha do terrorista e da evolução da preparação do atentado. Esta linha aparece sempre em itálico. O terrorista denomina-se Pantera, é movido essencialmente pelo ódio cego: «Ele era mais do que mau, ele odiava. Quanto ele odiava!» (FF: 269). Sente um enorme desejo de destruição, um desejo de, nessa guerra santa, matar o maior número possível de pessoas, na operação designada por «Minotauro» (vd. FF: 11 e 177). A história do Minotauro surge também ligada a Pamela, pois o pai diz-lhe que os novos estádios são os novos palácios de Cnossos (FF: 177). O Minotauro é aquele que mata por missão, não por uma determinação própria. ${ }^{6}$

O modo de pensar dos terroristas está bem exemplificado na perspectiva de Pantera, que segue cegamente as ordens que recebe: «Em espera durante anos sem agir. Suor corre-lhe pelas costas abaixo. Matar era um direito do mais forte, isso chama-se sobreviver, chama-se sangue» (FF: 9). Mais tarde saberemos que Pantera é um funcionário da Secção Anti-Droga da polícia. O leitor será ainda informado que o material para o atentado foi trazido na mala diplomática de um estado árabe, não passando por isso por qualquer controlo alfandegário.

Paralelamente à apresentação dos planos terroristas e sua evolução, seguimos as actividades antiterroristas da polícia, sob a direcção de Tizian Füssli. A polícia utiliza os bons ofícios dum grupo de rockers, que utiliza métodos longe da legalidade, por isso inacessíveis à corporação. Pamela conhece um deles, aprendendo a arte de beber absinto, mas também da corrupção de alguns indivíduos na polícia antidroga.

No fim, tudo está preparado para o atentado. Mas uma falha técnica ocasional no sistema de transmissões impedirá que a bomba, accionada pelo exterior, rebente, num final tipo deus ex machina. O plano da Pantera não se concretizou por razões alheias às actividades das forças de detecção, nem por causa de algum erro seu na preparação do atentado.

\footnotetext{
${ }^{6} \mathrm{O}$ Minotauro aqui referido segue a linha tradicional mitológica, em que o monstro aparece como sendo símbolo do mal. No século XX os surrealistas e escritores como Julio Cortázar e Jorge Luis Borges, seguem uma linha mitocrítica, apresentando o monstro como uma figura positiva.
} 
Nestes dois romances apreendemos muito do mundo à nossa volta. Não se trata de uma problemática suíça, mas universal, exemplificada em meios suíços. Mais do que as histórias, interessa precisamente o "preenchimento» de que falava Glauser.

A segunda autora seleccionada é Sabina Altermatt(1966-), nascida na cidade de Chur, capital do cantão dos Grisões. Alguns dos seus últimos textos têm o cantão e as montanhas como cenário, a dar expressão ao seu amor-ódio às montanhas. Uma personagem do romance Bergwasser, uma engenheira alemã, diz que as montanhas são belas quando se está lá em cima, sem o lado opressivo que elas podem ter quando se vêem a partir de baixo. Altermatt começa a publicar em 2005, com dois policiais passados em Zurique: Verrat in Zürich-West (2005) [Traição em Zurique-Oeste], onde a jovem polícia Anita Sanchez tem que se mover entre a cidade e as montanhas, num caso que se move entre o próximo e o distante, e Nervengift (2006) [Veneno para os nervos], onde a inspectora Gertrude Gut, uma mãe que tem que gerir sozinha a educação da sua criança, e também investigar o caso de um cadáver feminino encontrado no fundo do lago de Zurique. A partir de 2008 começa a escrever policiais centrados no cantão dos Grisões: Alpenrauschen (2009) [Sussurro dos Alpes], Bergwasser (2014) [Água das montanhas] e Jagdgeflüster (2015) [Rumores da caça]. A autora não opta por séries com as mesmas figuras de detecção, cada romance tem as suas. Desse modo sente-se mais livre para criar figuras novas: nos seus romances surgem retratos de mulheres fortes e independentes, tendo de unir a detecção e a vida profissional aos problemas familiares, sempre a pensar o que representa ter filhos, um tema que percorre a vida das mulheres dos três romances em questão. São postas em meios profissionais usualmente dominados por homens, como os túneis, as florestas, a caça. O «colorido local» ${ }^{7}$ é claramente marcado pelos nomes dos sítios reais, mas também com os nomes grisões de muitas das personagens. Nos seus policiais, além da trama e da apresentação dos locais alpinos, com a beleza e com tudo o que eles escondem, a autora interessa-se muito pelo lado psicológico, não só das mulheres com os papéis principais, mas também de outras mulheres, e dos homens que com elas se cruzam, apesar de estes, como se queixam alguns leitores, terem só papéis menores.

\footnotetext{
${ }^{7}$ Vários críticos utilizam a expressão «Lokalkolorit» para se referirem à importância da apresentação realista dos locais.
} 
Serão analisados os três romances «alpinos» de Altermatt, por ordem da sua aparição, ainda que, neste caso, a ordem seja indiferente, uma vez que são obras isoladas, não integradas em nenhuma série. Comum aos três é o papel central de mulheres como protagonistas. A polícia tem um papel muito pouco relevante na pesquisa, que envolve sempre uma dimensão política, colectiva e individual. Altermatt opta por uma situação narrativa autoral, mas baseando a sua apresentação em muitas situações dialógicas, permitindo, desse modo, a coexistência de diferentes pontos de vista, com a apresentação directa das tensões e conflitos entre o/as protagonistas, sem a intervenção dos narradores.

Começarei com Alpenrauschen. A acção inicia-se com o atropelamento mortal, com fuga, de uma deputada zuriquense, Franziska Padrun, muito dada a questões ambientais. A deputada tinha sido muito activa na luta contra a construção na zona de Engadin de um gigantesco centro de congressos. A jornalista Flurina Filli, ela própria nascida na zona, é enviada para investigar o caso. A firma imobiliária AlpinaInvest é suspeita de estar por detrás da morte, pouco tempo antes de uma votação na junta a favor ou contra a construção. De facto, tudo aponta nesta direcção, apesar da empresa tentar «comprar» os votos, organizando uma grande festa/manifestação na aldeia, a terra natal de Flurina Filli e onde Franziska morava. Aos poucos vai-se descobrindo que a empresa é conhecida por várias tentativas de suborno dos habitantes das zonas onde quer investir, porque tem que vencer a resistência dos «lá de cima», os habitantes das montanhas, muito receosos com a arrogância dos «lá de baixo», os de Zurique. Trata-se de um velho tema da literatura que envolve os Alpes, desde Johanna Spyri e a sua Heidi, à «Heimatliteratur», a Thomas Mann, com A Montanha Mágica, ou a Annemarie Schwarzenbach, com Flucht nach oben, entre muitos outros. Altermatt retoma nestes romances a atitude dos habitantes dos Alpes grisões face aos citadinos, de quem suspeitam que se querem aproveitar deles. Mas os «lá de baixo» (os «Unterländer») foram precisamente os que mais se mobilizaram contra a empresa, enquanto os da montanha, só vendo os seus interesses estreitos, queriam o centro, pelos empregos que a iniciativa traria, ignorando a destruição que isso representaria para a localidade. «Quai d'eiran quists da la bassa», diz uma das habitantes em reto-romano (Altermatt 2009: 72). ${ }^{8}$ O romance é, pois, a his-

\footnotetext{
${ }^{8} \mathrm{O}$ reto-romano ou romanche é uma das quatro línguas oficiais da Suíça falada por pouco mais de 50.000 pessoas, quer como língua materna quer como língua segunda. É falda sobretudo no cantão dos Grisões e divide-se em cinco dialectos diferentes, ainda que haja tentativas de uma unificação ortográfica, chamada «Rumantsch Grishum».
} 
(Tiefenhauer 2015). As linhas narrativas vão avançando, concluindo-se, depois de várias peripécias, que a assassina tinha sido a mulher do morto, por este se recusar a ter filhos com ela, mas que o teria feito com outra mulher da aldeia. Ela agiu de modo bem premeditado, tentando incriminar Mario, usando a arma dele para os seus fins. O romance termina tal como começa, com uma referência a um urso, espécie também objecto de narrativas lendárias, mantendo a circularidade contrapontística da estrutura romanesca, enquadrando a acção no meio da natureza, mostrando, assim, que, por detrás do idílio, aparecem forças malignas, não da natureza, mas dos habitantes.

Os romances de Altermatt ganham um interesse acrescido pela montagem de várias linhas narrativas, desde a da detecção até à vida pessoal e passional de algumas figuras, além de desenhar protagonistas fortes ( Powerfrauen», como refere Pfeiffer), mulheres independentes, lutadoras, não as heroicizando, antes humanizando-as, com pontes fortes e fracos.

Passemos agora à terceira autora apresentada. Petra Ivanov (1967-) nasce em Zurique, passa alguns anos nos EUA; escreve policiais, contos, literatura para adolescentes. Trabalhou no HEKS, um serviço de apoio das igrejas evangélicas da Suíça, tendo percebido a importância das histórias para veicular eficazmente alguns conteúdos. Esta consciência levou-a a iniciar a publicação de romances policiais, para além de livros para adolescentes e contos. ${ }^{11}$ Os policiais da autora, para lá do entretenimento próprio do género, querem transmitir outros valores importantes para os leitores. A este propósito, a autora revela numa entrevista: «Num policial posso veicular informações de um modo emocionante, sem gestos instrutivos, sem balizas morais» (Koenig 2013: 8). Por isso, encontramos nos seus romances permanentemente temas actuais, como a destruição do ambiente, as adopções ilegais, o comércio de mulheres, a prostituição infantil, as diferentes formas do poder, a ganância do dinheiro, as questões ligadas ao asilo. Para além destes temas, Ivanov dá grande espaço às questões ligadas às relações humanas. Fá-lo com um grande rigor, de modo realista, mostrando o modo como a equipa da polícia funciona internamente, para além das reacções pessoais da família, como refere na mesma entrevista. Desse modo, o leitor segue os passos profissionais e privados dos protagonistas.

\footnotetext{
${ }^{11}$ Ver informações sobre a série Meyer e Palushi (três títulos entre 2011 e 2016)) e Angst e Haas (20072010) em www.petraivanov.ch.
} 
Com os seus livros pretende atingir um público a que não chegava com os seus textos jornalísticos. Refere, numa entrevista a Magnus Leibundgut, que este tipo de textos permite mergulhar nos abismos da alma humana. Diz, ainda, que, apesar de se tratar de romances ficcionais, os espaços e as referências históricas têm que corresponder à verdade, sob pena de todo o texto perder credibilidade (cf. Leibundgut 2018).

Já há oito livros com a dupla Regina Flint, procuradora em Zurique e Bruno Cavalli, polícia de origem americana, mais precisamente cherokee, agora ao serviço da polícia da cidade. O modo como se encontraram nos EUA é relatado no romance Erster Funke (2017) [Primeira faísca], informação sonegada aos leitores até este volume, publicado entre o sétimo e o oitavo volumes da série. Ivanov aproveita o romance para introduzir temas candentes nas relações helvético-americanas, nomeadamente os escândalos bancários e a ajuda de algumas instituições com sede na Suíça a ajudar cidadãos norte-americanos a fugir aos impostos. Existe uma ficcionalização da situação, mas é evidente que por trás de tudo está essa triste realidade. Neste romance falta aquilo em que Ivanov é muito boa: a apresentação dos «ambientes».

Ao longo da série vamos seguir a linha do relacionamento entre Regina Flint e Bruno Cavalli, que levará a uma relação complexa e ao nascimento da filha Lily. Seguimos a difícil relação, pois Cavalli é um homem que não gosta da prisão que representa a família, apreciando a liberdade, por vezes difícil de conciliar com a vida familiar. Ivanov interessa-se pelos procedimentos policiais do grupo em que Cavalli trabalha e onde a procuradora é presença constante. $\mathrm{O}$ leitor vai-se apercebendo de diversas situações em Zurique e do labirinto em que a justiça está envolvida num mundo já em si complexo. Este facto vai levar o grupo à Europa de Leste, à Roménia, à Geórgia, à Argentina. ${ }^{12}$

Aqui serão apresentados o primeiro e o último volume da série. ${ }^{13}$ Em Fremde Hände seguimos, durante umas 400 páginas, as investigações de Regina Flint e

\footnotetext{
${ }^{12}$ O primeiro volume Fremde Hände (2005) [Mãos estranhas] passa-se na zona de prostituição mais conhecida da cidade. Já o segundo centra-se à volta da emigração com um incêndio criminoso num asilo para refugiados (Tote Träume (2006) [Sonhos mortos]). A dupla investiga depois as redes da Máfia Russa (Kalte Schüsse (2007) [Tiros frios]), as redes na Geórgia (Stille Lügen (2010) [Mentiras silenciosas]) e na Argentina (Leere Gräber (2012) [Campas vazias]). Num dos títulos, a dupla trata com um crime passado nas próprias entidades policiais (Tiefe Narben (2012) [Cicatrizes profundas]). Heiße Eisen (2015) [Ferros quentes], passa-se nas altas esferas financeiras zuriquenses. Já em 2018 publica Alte Feinde [Velhos Inimigos].

${ }^{13}$ Petra Ivanov: Fremde Hände, referido no texto como FH. O último livro da série até agora, Alte Feinde, será referido como AF.
} 
Bruno Cavalli em Zurique, quer os seus trajectos profissionais como os ligações complexas entre as pessoas, especialmente entre os dois protagonistas.

A acção pode ser apresentada em poucas linhas: numa central de tratamento de lixos aparece um cadáver numa mala dum carro. Regina e Cavalli vão investigar na zona de prostituição na cidade, deparando com uma rede de tráfego de mulheres, sobretudo jovens moldavas e albanesas. Os traficantes não recuam nos meios que utilizam, sendo que o motivo é sempre económico. Até que surge um segundo assassínio que, aparentemente, nada tem a ver com dinheiro.

Simultaneamente Flint e Cavalli têm que lutar para não reacender uma relação entre eles, que ameaça desequilibrar os dois na profissão e na vida privada. Ivanov utiliza um narrador na terceira pessoa, com algum mais saber, o que lhe permite organizar coerentemente as diferentes linhas, que podem parecer algo labirínticas, por causa da sua frequente interrupção e com um razoável número de figuras, incluindo Aurora, uma jovem albanesa, testemunha do homicídio da primeira rapariga.${ }^{14}$ Há um «gabinete de perspectivas», como Janser escreve na sua recensão. A acção está bem situada em Zurique, como diversas marcas topológicas o testemunham: o círculo à volta do meio da prostituição na Langstrasse, a questão das aterragens de aviões pelo sul, dadas as restrições impostas pelas autoridades alemães nos voos sobre território alemão, os nomes das ruas, o célebre restaurante Die Krone, ${ }^{15}$ as linhas dos eléctricos e outros aspectos da vida diária zuriquense. A cidade é apresentada pelas diferentes figuras, cada uma apresentando uma cartografia própria, dependente dos interesses de cada uma. Mas não é só pela cartografia que a vida de Zurique é apresentada; ligados à investigação aparecem alguns problemas da cidade: o problema da droga, as máfias albanesas, a prostituição forçada, a sida, o tráfego de mulheres, os ilegais. ${ }^{16}$

\footnotetext{
${ }^{14}$ Aurora, uma jovem albanesa, é testemunha do homicídio da primeira rapariga. Uma rapariga diz à autora, quando ela se deslocou à Albânia para recolher informações fidedignas: "Quando vires um Mercedes preto, foges!» (FH S. 7).

${ }^{15}$ Este célebre restaurante de Zurique tem sido palco de alguns romances policiais, por exemplo, Justiça de Friedrich Dürrenmatt.

${ }^{16}$ No segundo romance da série, Tote Träume, a acção centra-se na problemática dos asilados e do racismo. O lar onde vivem muitos asilados é incendiado. Para determinar o tempo histórico exacto, refere-se a final do Campeonato Europeu de Futebol, a ser transmitido pela televisão entre a Grécia e Portugal, que está a ser visto por algumas figuras do romance.
} 
Na Europa meio milhão de mulheres por ano são forçadas à prostituição [...] Muitas mulheres são enganadas por profissionais com falsas promessas de trabalho ou casamento disfarçado para irem para a Europa, algumas foram mesmo compradas às famílias». (FH: 245)

Deste modo informações do mundo real aparecem ligadas ao mundo fictício, dando-lhe credibilidade.

A violência familiar, sobretudo a exercida por homens sobre as mulheres, é tematizada, tal como a questão dos lixos urbanos para que a acção principal esteja bem enquadrada nos problemas gerais da sociedade: por exemplo, o primeiro cadáver aparece numa lixeira.

O último romance da série tem o título Alte Feinde. A autora recupera muitos elementos dos romances anteriores da série, permitindo ao leitor obter informações complementares que tinham ficado pendentes, nomeadamente o desaparecimento de Cavalli nos EUA, mas também o casamento de Fahrni, da polícia zuriquense, com Paz, uma paraguaia, que ajuda Regina e a filha. Neste livro a acção vai concentrar-se sobretudo na América, na comunidade índia dos cherokees. Ao longo do texto o leitor vai-se apercebendo das relações entre autoridades suíças e o FBI, nem sempre muito transparentes. Regina demora a perceber o que Cavalli já percebera, mas os dois não podem comunicar, pelo que seguimos as duas linhas em separado, marcadas pela indicação das datas nos inícios dos capítulos, com menção dos locais: Zurique e diversas localidades norte-americanas. Trata-se de uma vingança pessoal, em que o alvo a abater é Cavalli. O criminoso vai abatendo as pessoas que estão relacionados com ele. Uma das vítimas é assassinada na Suíça com uma arma do século XIX, utlizada na Guerra Civil americana. Numa terceira linha narrativa o leitor segue o trajecto daquela arma, desde a guerra em que foi utilizada até aos dias de hoje. Seguimos muitos episódios daquele conflito, em que esteve envolvido um emigrante suíço, que se torna comandante num campo de prisioneiros, em condições miseráveis, o que levou à sua condenação à morte. No presente narrativo está em curso a reabilitação da figura. O suíço assassinado estava ligado a essa reabilitação, pelo que se julgou que o assassinato seria uma vingança por esse acto de reescrita da história.

Cavalli é atingido, e a sua preocupação é manter Regina, Lily e o filho de um casamento anterior, Chris, a salvo. No fim, as linhas convergem com a viagem de Regina aos EUA, o que leva ao reencontro dos dois e posteriormente à morte 
do assassino. Os espaços suíços e norte-americanos estão bem referenciados, mantendo-se uma representação da realidade, que tem sido apanágio de toda esta série. Esta remete também para o "policial de relacionamento», onde se acompanha de perto as relações familiares. Dado que Cavalli e Regina trabalham para as autoridades policiais e judiciais suíças, centradas em Zurique, é natural que o lado profissional e o familiar se cruzem intimamente.

A autora refere que os locais que apresenta são os que conhece, transmitindo, assim, ao leitor a sua Zurique e a imagem que ela e a figura constroem dessa cidade. Ivanov confessa mesmo a Salome Müller que os passeios de Regina em Zurique correspondem a pausas na acção, concentrando-se no lado pessoal (Müller 2018). Com estes romances ela quer abrir perspectivas dos leitores ao abordarem a realidade (cf. Leibundgut 2018).

Ivanov editou com Mitra Devi (1963-) algumas antologias de policiais suíços, nomeadamente os dois volumes de Mord in Switzerland, onde, como escrevem as editoras, não há nos contos nada de típico suíço, a não ser o espaço geográfico e social: as cidades, o campo aparentemente idílico, mas com o mal a prosperar, escondido por baixo da superfície; ou as vistas dos Alpes, magníficas, mas escondendo outras realidades. ${ }^{17}$ Assassinos ou vítimas: à volta deles tecem-se histórias de crimes, passados em muitos cantões diferentes, pelas mãos de autores e autoras, alguns deles com muito humor (cf. Petri/Ivanov 2016: 8). Devi, escritora, jornalista, cineasta e artista, escreveu uma série de thrillers à volta de uma iraniana que vive em Zurique, sem grandes meios. Exerce a profissão de detective particular, o que lhe permite trabalhar mesmo sem autorização de residência. Recentemente escreveu com Ivanov o romance Schockfrost (2017), que se passa sobretudo em meios psiquiátricos, envolvendo a psicóloga Sarah e a família, nomeadamente o seu filho Dave, vítima de excessos de confiança na Internet. Trata-se de um psicothriller escrito por duas das mais importantes autoras do policial suíço alemânico.

\footnotetext{
${ }^{17}$ Nestes dois volumes são apresentados 36 contos, dos quais 20 são escritos por mulheres, e 16 por homens, representando cantões das quatro línguas nacionais (o alemão, o francês, o italiano e o reto-romano): dos 26 cantões e meio cantões que constituem a Suíça, só não estão representados um cantão e um meio-cantão. Comparando com os dois volumes editados por Paul Ott, Tatort Schweiz (2005) e Tatort Schweiz 2 (2007), na Limmat Verlag de Zurique, vemos que dos 41 contos seleccionados, 17 são se autoria feminina. Paul Ott opta pela apresentação dos textos na língua original, sem recorrer a traduções para o alemão, como fazem Devi/Ivanov.
} 


\section{Em jeito de conclusão}

Estamos perante três modos diferentes de apresentar o trabalho da justiça, o seu enquadramento e a relação com o real. Embora a problematização perante a realidade social esteja presente nos romances das três autoras, em Wyss temos um maior grau de questionamento. Os romances das três autoras são mais lentos e um pouco menos violentos do que muitos outras autoras estrangeiras. Incluem a ligação com o trabalho, a família, os ambientes, sobretudo quando as acções se situam em terras pequenas, onde a dicotomia «lá-em-baixo vs. cá-em-cima» está presente, estando o lado criminoso não «lá-em-baixo», como tudo parece indicar, mas nos meios pequenos. As três autoras incorporam nos seus livros o espaço como uma dimensão semântica, utilizando-o como parte integrante do cenário, desde as cidades suíças às aldeias dos Grisões. Esta dimensão só é importante para os leitores que tenham qualquer tipo de relação com esses espaços. Os outros realizarão em menor escala essa carga semântica inerente, construindo a sua construção do espaço a partir das próprias vivências de outros espaços ficcionais ou reais. Ligado a este aspecto de apresentação da realidade simbolizada na realidade ficcional está o lado de entretenimento típico do género.

Neste texto foram apresentadas três autoras distintas, mas que não são, em si, representativas do policial suíço escrito por mulheres, enquadrando-se, no entanto, na tipologia de Ott. Fica o convite para a descoberta desse mundo que o policial representa.

\section{Bibliografia}

ALTERMATT, Sabina (2009), Alpenrausch, München/Zürich, Piper. (2014), Bergwasser, München/Berlin/Zürich, Piper. (2015), Jagdgeflüster, München/Berlin/Zürich, Piper.

DEVI, Mitra/Petra Ivanov (2013), Mord in Switzerland, Band 1 und 2, Schwellbrunn, Appenzeller Verlag.

HASLER, Eveline (2007), «Fakten und Fiktion. Auf der Spurensuche», in Edgar Marsch (Hg.), Im Fadenkreuz, Zürich, Chronos: 81-87.

IVANOV, Petra (2009), Fremde Hände, Reihe Flint/Cavalli, Zürich, Unionsverlag. (2018), Alte Feinde, Reihe Flint/Cavalli, Zürich, Unionsverlag.

JANSER, Daniela (2005), «Spurensuche im Sex-Milieu des Kreises 4». In Tages-Anzeiger, 29. März 2005. 
KOENIG, Käthi (2013), «Fakten, mit Mord und Totschlag aufbereitet. In: reformiert, Nr. 4.2, April 2013, S. 8.

LEIBUNDGUT, Magnus (2018), «Wie aus Fakten Fiktion entsteht», Zürichsee-Zeitung (31.8.2018).

MARSCH, Edgar (2007), «Erzählen nach Schema? Über analytisches Schreiben im Neuen Schweizer Kriminalroman», in Edgar Marsch (Hg.) (2007), Im Fadenkreuz. Der neuere Schweizer Kriminalroman, Zürich, Chronos, 163-184.

(Hg.) (2007), Im Fadenkreuz. Der neuere Schweizer Kriminalroman, Zürich, Chronos, 89-98.

(2013), «Erzählen als Suche und Untersuchung», in Devi/Ivanov, Mord in Switzerland, Band 1, Schwellbrunn, Appenzeller Verlag.

METTLER, Felix (2007), «Die Psychologie im Kriminalroman», in Edgar Marsch (Hg.) (2007), Im Fadenkreuz. Der neuere Schweizer Kriminalroman, Zürich, Chronos, 89-98.

MÜLLER, Salome (2018), «Es geschah am helllichten Tag», Tages-Anzeiger (26.09.2018).

OTT, Paul (2005), Mord im Alpenglühen. Der Schweizer Kriminalroman - Geschichte und Gegenwart, Wuppertal. (2007), «Wie viel Wirklichkeit erträgt der Kriminalroman», in Edgar Marsch (Hg.), Im Fadenkreuz. Der neuere Schweizer Kriminalroman, Zürich, Chronos, 99-110.

PFEIFFER, Viola (2014), «Sabina Altermatt: ,Ich nehme jeweils nur meine Katze mit‘», Die Südostschweiz (05.02.2014).

TIEFENAUER, Brigitte (2015), «Die etwas andere Jagdbilanz», in Die Südostschweiz, 01.10.2015).

VOGT, Jochen (2007), «Triumph des Thrillers? Wiederkehr des Bösen? Einige (nicht nur) erzähltechnische Beobachtungen zur neueren Entwicklung des Kriminalromans», in Edgar Marsch (Hg.), Im Fadenkreuz. Der neuere Schweizer Kriminalroman, Zürich, Chronos, 39-53.

UBIETO, Miriam Llamas (2012), Lecturas del contacto: Manifestaciones estéticas de la interculturalidade y la transculturalidad, Madrid, Arco/Libros.

WYSS, Verena (2008),Todesformel, Gmeiner, Messkirch. (2010) Blutrunen, Gmeiner, Messkirch. (2012), Föhnfieber, Gmeiner, Messkirch.

ZEINDLER, Peter (2005), «Flucht aus der Enge. Der Schweizer Kriminalroman», In: Sandro M. Morald (Hg.): Mord als kreativer Prozess. Zum Kriminalroman der Gegenwart in Deutschland, Österreich und der Schweiz, Heidelberg, pp. 135-143. 


\section{Uta-Maria Heim.}

\section{Uma breve apresentação de uma destemida escritora experimental}

Jochen Vogt

Universität Duisburg-Essen

Desde os primeiros anos da década de 1990, a escritora Uta-Maria Heim navegou entre fronteiras de géneros, mormente a ficção policial e o romance. A definição das fronteiras não é assim tão simples. Devemos ainda mencionar, para uma descrição completa e sem omissões, que Heim também trabalhou outros géneros literários, como a poesia (obra publicada em 1985), contos, livros infantis, artigos académicos e ainda reportagens. Não podemos deixar ainda de referir as dúzias de peças ou de adaptações de peças radiofónicas (e também de romances policiais), pelas quais a autora foi responsável desde 1990, como escritora freelancer. Desde 2006, tem trabalhado integralmente como produtora e editora na Südwestrundfunk, sediada em Baden-Baden, tendo já produzido um elevado número de peças radiofónicas e de áudio-contos.

Esta criatividade no recurso ao meio sonoro, aproveitando as suas potencialidades estilísticas, também é provavelmente a razão para o uso efetivo e deveras impressionante de muitos monólogos, diálogos e passagens polifónicas nos romances. A própria Heim salienta: «[A rádio] tem uma enorme influência. Na maior parte das vezes, começo pela palavra falada. Para mim, contar histórias é sempre um ato verbal». Foi deste modo que a autora chegou à literatura e à ficção policial:

Era e continua a ser um facto: eu gosto de contar histórias. Escrevo desde os três anos de idade. Pintava formas, de modo algo atabalhoado, num pedaço de papel, e imaginava que estava a expressar os meus pensamentos ali; pensava que qualquer pessoa que olhasse para aquelas formas conseguiria ler os meus pensamentos. Nunca me ocorrera que eu própria era incapaz de decifrar aquelas formas - isto é, que não sabia ler. Tornei-me uma ávida leitora logo na primeira classe. Quanto 
tinha febre e ficava de cama, escrevia episódios que davam continuidade aos meus livros preferidos: Astrid Lindgren, Otfried Preußler ou outros clássicos da literatura infantil. Não conseguia aceitar que estas histórias conhecessem um fim. Não tinha, contudo, qualquer desejo de me tornar na Astrid Lindgren ou no Otfried Preußler. Aos onze anos fiquei sem mais livros para ler. Já lera tudo aquilo que era para maiores de doze anos, em segredo, ainda que o pessoal da biblioteca da paróquia estivesse sempre de olho em mim. E a secção infantil só ia até aos doze anos. Que haveria de fazer? Foi então que encontrei, a um canto, uma história policial, de páginas já gastas. Era 0 comboio das 16h50, de Agatha Christie. Li-o e (ao contrário de toda a região ocidental na altura) achei-o eletrizante. Desde então, as histórias policiais fascinam-me.

Uta-Maria Heim não é apenas uma escritora prolífica e extremamente versátil; é também uma autora cheia de ambições literárias, como as suas obras mais recentes demonstram de forma particularmente clara e evidente. A variação entre géneros, especialmente entre a ficção policial e a literatura convencional, como qualquer exercício de equilíbrio traz consigo o risco de alguém tropeçar ou cair. Procurar uma subversão da vida literária terá, certamente, um preço, quer para a carreira da autora, quer para os seus textos.

Uta Maria-Heim nasceu em plena Floresta Negra, na pequena cidade de Schramberg, na zona de Württemberg. O sudoeste alemão continua a ser importante para a vida e obra da autora: é uma espécie de relação leal de amor-ódio. Durante os seus estudos universitários (literatura, linguística e sociologia em Friburgo e em Estugarda), Heim tornou-se jornalista do Die Tageszeitung, um jornal diário de esquerda moderada, em 1983. É crítica e autora no jornal liberal Stuttgarter Zeitung e também na estação radiofónica Süddeutsche Rundfunk, desde 1987. Trabalharia mais tarde com muitos outros jornais e estações de rádio. Entre 1993 e 2002, como o seu trabalho reflete, viveu em Hamburgo e em Berlim, mas são as cidades germânicas do Sul, sobretudo Estugarda, além das zonas da Floresta Negra, do vale do Rio Neckar e dos Alpes suábios, que têm sido localizações recorrentes para a ação dos seus romances policiais. A primeira pessoa a referir esta relação de amor-ódio pela região onde Heim cresceu veio de um crítico, amigo da autora. Mas, na verdade, este pareceu-lhe, na altura, um julgamento algo severo, do qual a autora rapidamente se distanciou. «Não é, de todo, verdade», escreveu. 
Adoro o meu lar, é lá que estão todas as coisas que sou capaz de interiorizar e de expressar. No meu romance Heimstadt muss sterben [A cidade natal tem que morrer] procurei demonstrar aquilo que quero dizer. Incomoda-me que escritores progressistas apenas falem das suas origens quando apenas retornam na condição de exilados. O nosso lar afeta-nos, a cada um de nós. Eu já escrevia sobre o meu lar muito antes de uma qualquer outra de esquerda ou qualquer outra feminista se ter sentido capaz de o fazer. Na verdade, a palavra é um sinal de alerta para os conservadores. Se lhes damos esse tema, mais vale emigrarmos.

Os primeiros romances de Heim tinham títulos pouco atrativos. São disso exemplos The Das Rattenprinzip (1991) [O princípio das ratazanas] ou Die Kakerlakenstadt (1993) [A cidade das baratas]. No início dos anos 90, estas obras foram publicadas na lendária «série negra» de livros de capa mole da editora Rowohlt, tendo sido amplamente elogiadas e tendo vencido, por duas vezes, o Deutscher Krimipreis (Prémio Alemão do Romance Policial). O burburinho em torno de Heim diminuiu então, apesar de a autora continuar a publicar novos romances quase todos os anos. Estes eram apenas parcialmente considerados romances policiais, tendo sido apresentados por diferentes editoras. Isto pode ser visto como um indicador da dificuldade que Heim teve para encontrar o seu lugar no meio literário. Agora que estes livros estão a aparecer com menor frequência, o conteúdo e sofisticação formal têm saído beneficiados.

Os romances policiais de Uta-Maria Heim - incluindo os dois supramencionados, e ainda outros, como Engelchens Ende (1999) [O fim dos anjinhos], Dreckskind (2006) [A criança do lixo], Wespennest (2009) [O ninho das vespas], e Der Sieg des Rattenprinzips (2009) [O princípio da vitória das ratazanas] - não constituem uma série propriamente dita. Poder-se-á, talvez, descrevê-los como uma mistura ou, como refere a teoria francesa (que Heim conhece e trata com alguns apartes irónicos), um «rizoma», no qual as histórias e os destinos de cada personagem vão sendo são acompanhados - mesmo que por longos períodos de tempo. Algumas figuras surgem por diversas vezes como uma espécie de comédie humaine de pequenos crimes na Suábia. As personagens ditas permanentes de Heim incluem o jornalista Udo Winterhalter, a sua namorada de longa data, Claudia Roth (não confundir com a atual Vice-Presidente do Parlamento Alemão!) e o pai desta, o «Karl vermelho», um velho comunista, conflituoso, com tendências anarquistas - personagem divertida, elemento cómico capaz de fazer o leitor rir. Também ficamos a conhecer os investigadores Anita Wolkenstein e Timo 
ria que apenas tende a premiar o incompreensível se este for «suficientemente intelectual e refinado».

Este estilo reflete-se no estilo de leitura altamente individualista, eclético, para não dizer caótico, da autora. Escreve a própria:

Durante um tempo fui fã de Elfriede Jelinek - durante o mestrado cheguei a discutir partes do seu trabalho - mas esta autora nunca teve uma influência permanente no meu trabalho. O único escritor cujos livros adoro e de quem me sinto próxima quando escrevo é Markus Werner. Gosto sempre de o citar e faço-o repetidamente. Gosto de ler as histórias policiais de Barbara Vine (também conhecida como Ruth Rendell), sempre na versão original em inglês. Fora isso, as minhas leituras são um pouco fruto do acaso. Inspiro-me em livrarias de livros em segunda mão, pelos livros que as pessoas deitam fora - esse é, na verdade, algo que faço por princípio. Gosto de explorar as pistas - não raras vezes ténues - que os outros autores deixam para trás, as suas vidas, os seus sucessos, os seus falhanços. Há autores e livros por aí de que ninguém se ouviu falar, mesmo que fossem conhecidos há uns anos. É como o meu pequeno projeto subversivo de arte - resgatar livros do esquecimento perene. Mas claro, às vezes deito-os mesmo fora.

Uma característica do estilo narrativo distinto e idiossincrático de Heim - particularmente nas suas obras mais recentes - permanece a combinação algo frouxa de cenas características dos vários tipos de romances: do romance policial ao thriller psicológico, passando ainda pelo thriller jurídico, pelo romance familiar e até pelo romance picaresco. Vemos este último género a ser usado num dos romances mais recentes de Heim: o satírico, grotesco, até, Heimstadt muss sterben (2016). Esta história ocorre numa pequena cidade semifictícia na região do Neckar, sob controlo de um gangue de traficantes de armas. Da sua forma peculiar, a autora usa também elementos paratextuais não-fictícios como prefácios ou epílogos, interliga associações contemporâneas a transportes de armas alemãs para o México, insere documentos históricos ou pseudo-históricos e usa ainda notas de rodapé explicativas, tais como as que se encontram em textos académicos. Tudo isto pode ser encontrado, com ênfases e combinações diferentes, em outros dois romances de relevo recentes.

Feierabend, (2011) [Depois do trabalho] é uma montagem de monólogos de três personagens femininas, que inicialmente parece ser uma «história de autoconhecimento» da literatura de mulheres dos anos 80. No epicentro do enredo está um problema entre mãe e filha. Um ladrão insignificante traz incerteza, 
numa primeira instância. Mas depois é a história familiar que conduz à verdadeira questão: o que aconteceu à Tia Brunhilde, uma criança com dificuldades de aprendizagem, sentenciada à morte em Grafeneck? Terá sido uma das vítimas dos assassinatos em massa em câmara de gás, ou ter-lhe-á alguém bem-intencionado permitido uma «morte às suas próprias mãos»? Este não é um caso de polícia, mas o leitor-detetive mais atento pode encontrar uma possível resposta.É a resposta certa? «Ninguém sabe», pode ler-se mais em mais do que uma ocasião ao longo do livro.

A importância - até mesmo o domínio - das personagens femininas neste e noutros romances leva-nos a algumas questões de género presentes na obra de Heim. Viramo-nos para o feminismo e para a influência que este exerce na escrita da autora. «O movimento feminista constituiu um ponto de viragem para mim», escreve Heim.

Tinha doze anos quando li Häutungen, de Verena Stefan. A seguir, li autoras como Anja Meulenbelt. Tornei-me numa feminista entusiasta. Apanhava boleias para festivais de mulheres, tive relações de amizade intensas com outras mulheres. No final da década de 1970 e no início dos anos 80 senti que as normas e convenções da geração dos meus pais (fui educada, desde a infância, com valores artísticos-Católicos e comunistas antifascistas) já estavam completamente ultrapassadas. Estávamos no meio de uma revolução cultural. Senti-me uma socialista, os meus companheiros eram membros de partidos e, mais tarde, intelectuais de esquerda. Em retrospetiva, sinto-me grata por poder ter encontrado um refúgio nesta revolta generalizada. Não foi sequer importante que essa revolta já estivesse a perder força, que já quase não fosse real.

Se nos questionarmos se Heim se sente confortável com o conceito coloquial e impreciso da «ficção policial de mulheres», a sua resposta é clara.

A descrição da escrita como «ficção policial de mulheres» só é útil se a definirmos claramente - e só faríamos uma coisa dessas se, em primeiro lugar, considerássemos interessante fazê-lo. Na literatura alemã começou com Doris Gercke, sendo hoje representada por nomes como Monika Geier e Merle Kröger. De modo geral, tem havido um enorme aumento de qualidade e de variedade deste género de escrita, mas eu não estou particularmente interessada nele. Quando publiquei o meu primeiro romance policial, Das Rattenprinzip, em 1991, não se tratava de «ficção policial de mulheres»: era um romance policial de uma jovem mulher que estava a escrever o que lhe apetecia. 
O melhor e mais ambicioso romance de Heim até à data tem uma citação de Hölderlin como título: Wem sonst als Dir (2013) [Quem senão a ti]. As personagens e os eventos da história são ainda mais opacos do que em Feierabend. Começa como uma história de um caso judicial e que depois nos leva às catacumbas das histórias e crónicas familiares alemãs. O já envelhecido Juiz K. vive atormentado por um «julgamento», tal como vivia o seu homónimo no romance mundialmente conhecido de Kafka. Há vinte anos, o juiz decretou a pena máxima ao jovem professor, Schöller, por alegadamente ter esfaqueado a sua própria mãe. Agora, K. enfrenta a angústia da dúvida: viaja até Tübingen, onde Hölderlin, poeta mentalmente instável com que Schöller se identificava, viveu e sofreu. E que fardo carrega Schöller! Será a sua mãe que trabalhara como cozinheira responsável pela prisão de um homem inocente? Depois Schöller escapa à prisão e à ala psiquiátrica e entra no infame centro de Grafeneck mas não fazia ideia do que ali se passava. A sua irmã voltou-se para o terrorismo de esquerda da década de 1970, e terá morrido após a queda do Muro de Berlim, nos últimos meses da RDA. «Ninguém sabe realmente a verdade» - uma vez mais, fica ao cargo do leitor perceber o que realmente aconteceu. As várias vozes, nem sempre marcadas de forma clara, tornam esta investigação tão intrigante quanto difícil. Trata-se de uma rede de referências e alusões intertextuais, quer no próprio enredo, com múltiplas referências a Hölderlin, quer ao longo do texto, onde além de Kafka, também é referido Paul Celan. O leitor pode apreciar o quão deliberadamente a autora desafia e até transcende a fronteira entre a literatura do género e a chamada alta literatura.

No processo de escolha das suas formas e expressões literárias, Heim trata os géneros literários convencionais e os valores a estes associados com alguma ironia, por vezes com certo desdém. A sua escrita verga os géneros literários; isso demonstra liberdade artística e destemor, embora a coloque em risco de perder algum equilíbrio. Podemos verificá-lo ao ler os seus livros mais recentes, Heimstadt muss sterben (que mencionámos acima) e ainda Toskanische Beichte (2017) [Confissão na Toscânia] e Toskanisches Feuer (2018) [Fogo na Toscânia]. Os dois últimos são os primeiros volumes de uma série de enigmas com uma boa dose de comédia, em que um padre católico da zona do Lago de Constança conduz investigações em casa e no estrangeiro. Estes livros levantam, mais uma vez, a questão do lugar a que pertence Uta-Maria Heim na cena literária e, mais particularmente, no mundo da ficção policial - ramo cada vez mais dominado por considerações de índole financeira. O que leva Heim a continuar as suas experiências com 
tipos díspares de romances, temas e estilos e, sobretudo, com tão variados efeitos? Porque o faz a autora, especialmente quando tal experimentação pode custar-lhe sucessos e lucros futuros? Uma vez mais, Uta-Maria Heim é clara na resposta:

«Não sei fazê-lo de outro modo», responde. «Acima de tudo, escrevo histórias sobre outros mundos, sobre contra-mundos, por assim dizer. Não é possível fazer isto com técnicas de escrita já criadas. Não é uma questão de querer ser original. Sempre que escrevo, o texto automaticamente torna-se difícil, sempre e de diferentes maneiras. Isso significa que é preciso encontrar a estratégia certa se se quiser vender livros - mas eu não estou interessada em estratégias.

No início do meu último policial, Toskanische Beichte, coloco uma citação que encontrei no folheto Aos nossos amigos do Comité Invisível. «Temos de dar aos mais banais detalhes do dia-a-dia da vida comunitária a mesma atenção que damos à revolução». Essa frase foi uma feliz descoberta minha, e deixou-me extasiada. Se aprendermos a viver dessa forma, cada encontro que tenhamos na vida, por muito sombrio que possa ser, irá sempre demonstrar a sua faceta mais verdadeira.

Tradução de Cristina Villas-Boas 



\section{Batya Gur e os mistérios dos humanos}

Maria João Falcão

Comecei a ler Batya Gur no final dos anos noventa, em Israel, onde vivi cinco anos, e conheci bem a realidade de que fala. Interessou-me porque descobri uma criadora de mundos e de personagens quase «reais», de tão vívidas e humanas. De facto, nos livros da autora, mais importante do que a intriga policial é a criação de ambientes e de personagens tão autênticas que quase parecem «pessoas». Ambientes e submundos fechados sobre si próprios e tão verosímeis quanto as inimizades e os conflitos que neles se geram. É a sociedade e os seus diversos «mundos» paralelos - a que chamou, pelo isolamento em que vivem, de «insulares» - que Batya Gur analisa.

Outro aspecto das suas obras que me fascinou foi o interesse pela análise psicológica que demonstra. A começar pelo seu herói, o inspector Michael Ohayon, judeu sefardita, aparentemente duro, mas «doce e sensível por dentro», cuja preocupação não é julgar ou condenar, mas sim compreender, à maneira do Comissário Maigret, de Georges Simenon.

Batya Gur nasceu em Telavive em 1 de Setembro de 1947, um ano antes da criação do estado de Israel. Batya Mann é filha de pais judeus alemães, sobreviventes da Shoah. O apelido Gur vem-lhe do segundo marido. Habitou nos arredores de Telavive, em Ramat Gan. Exerceu a profissão de professora de Literatura Hebraica no ensino secundário e na Universidade e foi colaboradora do prestigioso jornal Haaretz, onde fazia crítica literária, tendo escrito diversos artigos e ensaios políticos sobre a cidade de Jerusalém, ou os colonatos ao Sul de Israel temas escaldantes ainda hoje.

Morre cedo com um cancro, em 19 de Maio de 2005, deixando escritos apenas seis livros. Uma perda não só para a literatura policial como também para a cultura em geral. Batya Gur falava com conhecimento profundo da rea- 
lidade de um país complexo, com situações paradoxais, como sublinhou Ari Shavit no subtítulo do seu livro My Promised Land: The Triumph and Tragedy of Israel. ${ }^{1}$ E penso agora: o que teria continuado a escrever - e a contar e a fazer - Batya Gur se não tivesse morrido com 57 anos? Batya Gur situava-se politicamente na esquerda do Partido Trabalhista de Israel - e sempre defendeu um Estado aberto onde fosse possível (con)viverem dois povos, através de negociações que conduzissem à paz entre eles, num diálogo procurado com os vizinhos inimigos.

Só, tarde, com 39 anos, decidiu escrever romances policiais. Quando começou, tinha já uma bagagem intelectual e cultural raras. As suas obras não se esgotam na intriga policial e nos mistérios que cria, mas abrem-se a questões complexas de ordem histórica e existencial, como a situação de Israel no mapa político do Médio Oriente ou os problemas universais do ser humano e os paradoxos da vida.

Mais do que os assuntos que escolhe, são as personagens e os ambientes que a singularizam. Os romances focam realidades e grupos diferentes relativamente autónomos na sociedade em que se inserem, sejam eles o Círculo de Psicanalistas, o Campus Universitário, a Orquestra Sinfónica de Jerusalém e os músicos que a compõem, o «kibbutz» e os seus habitantes, a comunidade étnica dos iemenitas em Jerusalém ou ainda o mundo da televisão do Estado e das intrigas e lobbies dos «media».

Os livros de Batya Gur reflectem sobre os equilíbrios instáveis, as frustrações passadas, os ódios e ressentimentos, as invejas - as razões humanas ligadas às pequenas coisas aparentemente insignificantes que se sofrem e deixam marcas ou que dificilmente se ultrapassam. Todas aquelas coisas que, num átimo, podem despoletar, na mente frágil de um doente ou de um psicopata, mas também em qualquer ser humano comum, um impulso mortífero. E que vão conduzir à destruição de outro ser humano.

Tudo isso prendeu os leitores. Quando a escritora morreu, perceberam que se tinha calado uma voz invulgar e que tinham acabado para sempre os livros do humano «inspector Michael Ohayon»; muitos sentiram-se abandonados - à imagem do que sentiram os leitores de leitores de Conan Doyle, quando este resolveu «matar» a criatura Sherlock Holmes. Nós, fiéis leitores, sabíamos que era o final de um mundo «especial» a que nos tínhamos habituado. Um mundo rico

\footnotetext{
${ }^{1}$ Ari Shavit nasceu em 1957, em Rehovot. Jornalista, comentador na televisão pública israelita, ensaísta e editorialista do mais importante jornal diário de Israel, Haaretz (jornal de inclinação liberal, de esquerda). Li a obra na tradução italiana, La mia terra promessa (Sperling \& Kupfer), 2013.
} 
de experiências, com vivências e gentes desconhecidas do nosso quotidiano, que, depois de tantas leituras, já faziam parte da nossa mundividência. Batya Gur e Michael Ohayon tinham-se tornado numa companhia certa, fiel, que em cada romance nos arrastava com eles, na pesquisa das causas psicológicas e humanas deste ou daquele crime hediondo.

A obra de Batya Gur está traduzida na íntegra em vários países. Em Espanha, por exemplo, a editora é sempre a mesma, a «Siruela». A escritora era muito apreciada nesse país e foi convidada, frequentemente, para fazer conferências e participar na Semana del Negro, em Gijón, em 2003. Em França, estão traduzidos todos os livros em várias colecções desde a clássica Gallimard às edições da Poche ou Folio. Em língua inglesa, foi igualmente traduzida em Nova Iorque, Londres, Toronto e Sydney pela editora Harper Collins. Está publicada em muitas outras línguas. Em Portugal, encontramos apenas a tradução de The Saturday Morning Murder (1988), na Relógio d’Água, com o título O Assassínio de Sábado de Manhã: um Caso Psicanalítico.

O primeiro livro de Batya Gur intitula-se O Assassínio no Sábado de Manhã: um Caso Psicanalítico (The Saturday Morning Murder, 1988). O romance teve sucesso imediato entre o público israelita. Baseia-se em figuras reais transformadas em personagens «de papel», de ficção. Foi logo adaptado para uma série de seis episódios, na televisão israelita, com grande êxito. A intriga parece simples. Numa manhã, silenciosa e tranquila, ocorre um acontecimento estranho: Eva Neidorf, psicanalista e professora muito respeitada, é encontrada morta na sede da Sociedade Psicanalítica de Jerusalém. $\mathrm{O}$ «clube» dos Psicanalistas é um mundo de judeus «seculares», que seguem as teorias de Freud e de outros psicanalistas judeus. Uma comunidade científica fechada ao mundo, com regras éticas rígidas. Nessa manhã de «shabatt», «em que o sol de Março brilhava e os passarinhos cantavam (...) Shlomo Gold, entusiasmado com a perspectiva de se encontrar com Eva Neidorf, sai cedo de casa em Beit Hakerem para ir arranjar o salão onde se realizaria a conferência» (Gur 2002: 9). Shlomo Gold é psicanalista também e, durante quatro anos, fizera psicanálise com Eva Neidorf e ouvira todas as suas conferências com entusiasmo e emoção. Ao chegar ao Instituto, descobre a professora, que parecia adormecida no cadeirão detrás da secretária, com a cabeça apoiada no braço. Mas Eva Neidorf fora morta com um tiro na cabeça. Nessa tarde mesmo, a professora deveria proferir uma Conferência com o título «Alguns Aspectos dos Problemas Éticos e Legais do Tratamento Analítico», na Psicanálise. A conferência era aguardada com grande curiosidade, entusiasmo, mas também 
Recorde-se, em traços largos, o que foram os kibbutzim. O kibbutz ou «ajuntamento» agrícola (o equivalente à palavra em hebraico) foi criado pelos judeus askhenazi, vindos da Europa do Norte e da Rússia, chegados à Palestina, imbuídos dos ideais socialistas do «sionismo». Para eles, era fundamental manter viva a cultura trazida de tão longe. Faziam parte do chamado «Movimento Bilu», cujo objectivo era a criação de ajuntamentos agrícolas de judeus e que defendia a ida dos judeus para a Terra de Israel. Foram os primeiros judeus a chegar à Palestina Otomana, em 1882, vindos de Kharkiv. Anos depois, em Abril de 1903, acontece um pogrom, na capital da Moldávia, no qual são mortos cerca de cinquenta judeus e feridos várias dezenas. É sentida a urgência de arranjar uma terra para esses judeus condenados a morrer. Theodore Hertzl, um dos teóricos do movimento sionista, decide comprar a propriedade que a família Sarsouk possuía na Palestina e transferir os sobreviventes para ali. Vêm escorraçados da Europa, com uma vontade inabalável de construir um país para si próprios, onde possam viver em segurança. Conta Ari Shavit no livro acima citado, o que se passa no primeiro kibbutz, o de Degania:

Eram jovens - órfãos de «pogroms» na Polónia e na Ucrânia - e, com eles, criam-se as novas estruturas, as novas tecnologias e os novos estudos. Deixaram para trás a Europa e tudo: pais, famílias destruídas que vieram fixar-se num local inóspito e duro, onde tinham a esperança de criar um sítio de paz para todos os judeus perseguidos de terra em terra, pelo mundo. Não traziam mais nada. Apenas, a juventude e a esperança. (...) Eram idealistas tolstoianos chegados à Palestina otomana à procura da salvação, nacional ou individual, adoptando um socialismo humano e amigável para o ambiente circunstante. (Shavit 2013: 24-26)

Em 1921, surge o moderno Kibbutz de Ein Harod. Escreve Shavit:

Antes e depois do Holocausto, começam a aparecer os fugitivos da Polónia, Rússia, Alemanha, Áustria e, no final da Guerra, vieram os sobreviventes dos campos. (...) Eram esses os ideais dos jovens chegados ali, sem nada, sem futuro, sem família, os que não têm lugar na Europa a que julgavam pertencer. O Sionismo começara a entusiasmar os mais jovens que procuraram a terra prometida onde a «sentiam» mais perto. (ibidem)

O sonho sionista era o da criação de comunidades agrícolas, numa mistura de ideais revolucionários entre «socialismo»e «sionismo». Procura realizar uma 
forma de socialismo justo, igualitário. O kibbutz foi essa unidade agrícola comunitária, com regras definidas e tarefas atribuídas, destinado a «criar» uma família para os «órfãos» - e para todos os refugiados e fugitivos. Pretendiam alimentar a sua população com os produtos cultivados e criar alguma riqueza, através dos trabalhos variados da comunidade, como modo de subsistência.

Assim, na Palestina (anteriormente pertencente ao Império Otomano e agora sob o Mandato Britânico desde 1920), esses jovens, agricultores e construtores improvisados, desbravaram e cavaram as terras, áridas e pedregosas, para plantarem o essencial da comida que iam comer, as árvores dos frutos que iriam comer. Os kibbutzeiros, como lhes chama o meu amigo Inácio Steinhardt, ${ }^{4}$ fizeram o impossível naquela terra agreste e dura. Sobre as actividades desenvolvidas no Kibbutz, escreve Shavit:

(...) plantaram laranjais e mais laranjais, cruzaram estirpes de laranjeiras diversas. Instalaram enfermarias e sentiram-se felizes por ajudar os vizinhos árabes das aldeias próximas, cujos filhos morriam de malária, disenteria e cujos campos pouco produziam. (...) Os jovens deram os seus ensinamentos, e foram bem recebidos de início. Criaram benefícios para árabes e judeus, com uma agricultura de processos modernos. (Shavit 2013: 23-24)

E lembro uma passagem do livro de Amos Oz, saído em 2002, Une histoire d'amour et de ténèbres, que li na tradução francesa. Amos Oz, depois do suicídio da mãe, foi com 15 anos para o kibbutz Hulda, autorizado pelo pai, onde viveu uns anos e onde terminou os estudos secundários. Diz-nos Oz:

Ao cair da noite, pegava num livro na casa Hertzl, o centro cultural que ficava no extremo do kibbutz. Havia uma sala de leitura onde se encontravam todas as noites alguns velhos celibatários que folheavam os jornais diários e os semanários e se lançavam em discussões épicas. (...) Instalava-me ali a ler até à meia-noite quando os olhos começavam a fechar-se sozinhos. Era ali que tinha recomeçado a escrever, longe dos lugares indiscretos. (Oz 2002: 778; minha tradução)

Hoje restam muito poucos kibbutz, e a ideia inicial comunitária, perdeu-se. Esvaziaram-se de gente nova. Lá fora, nas cidades modernas do resto do país,

\footnotetext{
${ }^{4}$ Nascido em Lisboa, Inácio Steinhardt é filho de pais polacos e vive em Israel há muitos anos.
} 
havia outros modos de vida, outras facilidades que os atraíam. A verdade é que tudo mudara - como tudo muda - com o passar do tempo.

No romance de Batya Gur, Murder on a Kibbutz: a communal case, vemos como a função de «utilidade comunal» se desvanecera - muitos dos kibbutzim foram privatizados. Nos lugares onde dantes cresciam abrunheiros e macieiras, cresce agora, em monocultura», a planta de um «cactus» destinado à indústria de cremes e produtos de beleza, que muitos consideram a «degradação» da missão do kibbutz e da acção original do sionismo, feita de idealismo e altruísmo, sem desejo de ganho.

Por outro lado, tinham aparecido os que pretendiam fazer alterações no estatuto e nos hábitos dos residentes do kibbutz. Era gente de fora, não residentes, que vinham trabalhar nos campos. Seriam essas mudanças mal aceites? Ou seria outra coisa que corria mal? A verdade é que algo vai provocar a morte da secretária do kibbutz, a jovem e bela Osnat Harel, assassinada sem motivo aparente, uma vez que era apreciada por todos.

Anos depois, Batya Gur surge com outro romance completamente diferente, num cenário inesperado. Intitula-se Murder Duet: a musical case ${ }^{5}$ e é datado de 1999-2000. Uma intriga policial dramática que se move no mundo da música, o dos componentes da Orquestra Sinfónica de Jerusalém. Num curto espaço de tempo, acontecem dois crimes brutais: dois violinistas da orquestra, pai e filho, são assassinados.

Tinham passado dois anos desde a última aparição de Michael Ohayon, que durante esse tempo estivera ausente da sua unidade policial, a estudar Direito. Era agora Inspector-Chefe. O romance abre com uma imagem de harmonia e de beleza: «Tão perfeito era o silêncio antes de a música rebentar pela sala, tanta a calma, que parecia ter-se sentido a respiração profunda de alguém antes da primeira nota e logo erguesse a batuta e impusesse silêncio completo no mundo». (Gur 2004: 2; minha tradução). O romance começa com o «nosso» inspector, sentado na poltrona da sala de estar a ler enquanto ouve a abertura da Primeira Sinfonia de Brahms, tocada pela Filarmónica de Berlim e dirigida pelo maestro italiano Carlo Maria Giulini. A autora revela os seus conhecimentos sobre a música clássica - com pormenorização de músicos e tipos de música - o que poderia afastar os leitores menos interessados na música clássica. No entanto,

\footnotetext{
${ }^{5}$ O livro Murder Duet: a musical case (datado originariamente de 1999-2000), editado por Harper Collins Publishers.
} 
as suas explicações não são gratuitas; elas são facilmente compreensíveis e interessantes e articulam-se com algumas histórias divertidas sobre assuntos musicais, como por exemplo a descoberta de Vivaldi, por Michael.

No decorrer da acção, vai aparecer a figura simpática e misteriosa de Nita van Gelden, violoncelista e vizinha de Michael, que muito esconde de si e da dramática história familiar dos Van Gelden, músicos de origem holandesa. É Nita van Gelden que conta, por exemplo, como Dvorák, discípulo de Brahms, tivera por ele toda a vida uma enorme admiração. Brahms está a morrer com um cancro no fígado e Dvorak, homem muito religioso, vai visitá-lo. Ao sair do quarto, comovido, diz: «Uma alma tão nobre, como é possível não acreditar em nada?»

Ohayon pergunta: «O que é que não está certo?» e Nita responde: «Que Brahms não tinha nenhuma relação com Deus. Claro que tinha, só que não era o Deus de Dvorák» (idem: 29-30).

Toda a acção vai prosseguir sob o «signo da música»: da música barroca em especial: Vivaldi, Cimarosa e outros mestres; do Maestro Carlo Maria Giulini, italiano, a Daniel Barenboim, israelita; de Leonard Bernstein a Glen Gould tudo (ou quase tudo) é possível encontrar aqui sobre música clássica.

Em Murder Duet: a musical case é também abordado o tema da literatura policial e dos autores e detectives famosos. Assim, referem-se Edgar Allan Poe, Sherlock Holmes e o Comissário Maigret, e fala-se da solidão dos que se dedicam a perseguir o crime - porque estes detectives nunca poderiam ter tido uma vida normal. Diz Michael: «Um detective não pode realmente dar-se ao luxo de casar e se o fizer vai ter muitas complicações. Nem pode ter filhos, tal como verificamos desde Sherlock Holmes e Edgar Allan Poe» (idem: 245; minha tradução). Ela perguntou, sem ironia alguma: «Talvez te lembres apenas da solidão do detective nas histórias? No fundo, a ficção é outra coisa... mas essa ideia... sim reparei nisso. Até o Comissário Maigret. Tenho a certeza de que gostas dele, do Maigret de Simenon» (idem: 246; minha tradução).

E o diálogo continua, agora tendo como tema o casal Maigret, numa articulação da ficção com o discurso crítico sobre o género policial.

Logo no início do livro, há um acontecimento que leva Ohayon a fingir «viver» com Nita, como se mantivessem uma relação. Tudo isto por causa do aparecimento de um bebé, uma menina, misteriosamente abandonado à porta de Michael, num caixote de cartão. Ele decidiu recolher a criança até descobrir quem era a mãe e por que razão a deixara à sua porta, interrompendo, ainda por cima, a audição da Sinfonia de Brahms: «Quando pusera o CD no aparelho e car- 
regou no botão, por um instante teve a sensação de ouvir um grito muito fraco» (idem: 3). Nita era mãe de uma criança pequena e oferece-se para tomar conta da bebé e ajudá-lo a reorganizar a confusão que resultou daquela decisão de Ohayon. Chamado para investigar a morte dos músicos, Michael Ohayon descobre que as vítimas eram o pai e o irmão de Nita que ela nunca referira. O que leva as relações entre os dois vizinhos a esfriarem um pouco.

Violoncelista ela. Violinistas eles. Todo um universo de música - da magnífica música clássica - aliado agora a uma morte cruel. É com violência inaudita que o irmão de Nita, Gabriel Van Gelden, é assassinado, garroteado nos bastidores, durante o concerto, com uma das cordas do próprio violino. Entram também em cena personagens menores, mas que conseguem ter sempre uma presença - e nunca são «clichés» ou estereótipos. Trata-se de mais uma história triste e humana, como são as histórias de Batya Gur em que se sente bater o coração do «sabra», com humanidade e compaixão.

Michael Ohayon, apesar de parecer distante muitas vezes, tem um coração compassivo. A escritora diz que ele era sabra, nome dado, metaforicamente, aos israelitas nascidos em Israel. Tal como o fruto do «cactus», o sabra (figo da Índia ou figo de Barbarie), assim são os israelitas: «cheio de picos por fora e doce por dentro».

O livro que se segue em data intitula-se Bethlehem Road Murder: a Michael Ohayon mystery 6 e é publicado em 2004. Refere-se a acontecimentos mais recentes, passados a seguir à segunda «Intifada». As lutas entre judeus e árabes, feitas de incompreensões e ressentimentos, vêm dos tempos da criação do Estado de Israel, em 1948. E a situação de Israel é ainda hoje uma situação paradoxal.

Volto ao livro de Ari Shavit:

Desde que tenho memória, recordo o medo. Um medo existencial. O Israel em que cresci, o da metade dos anos 60, era um país vital, exuberante, cheio de esperança, mas eu tinha a constante sensação de que, para além das belas casas e dos jardins bem tratados da alta burguesia da minha cidade natal, se agitava um oceano ameaçador. Receava que esse oceano um dia transbordasse e nos submergisse todos. (Shavit 2013: 10)

\footnotetext{
${ }^{6}$ Bethlehem Road Murder: a Michael Ohayon mystery sai em Israel em 1999, mas no estrangeiro é publicado em 2004, pela Harper Collins Publishers.
} 
E adiante continua a explicar essa sensação de «vulnerabilidade» de Israel, naquela «remota província otomana» (idem: 10). Temos a sensação de que Batya Gur decidira referir-se mais directamente à situação do país e revelar uma preocupação política - como se pretendesse ter maior vontade de intervenção. E ter a coragem necessária para afrontar certos problemas políticos e mostrar-se crítica. O facto de Batya Gur ter escolhido um herói sefardita tem um significado importante e revela uma atitude inesperada e audaciosa. Como refere o artigo em Le monde, a criatura que ela sentia como seu duplo é - ao contrário dela judia askhenazita - "um judeu sefardita de origem marroquina». ${ }^{7}$

Segundo afirma Ziva Avran, professora de Literatura Hebraica, na Universidade de Lille, «escolher um herói sefardita era, para ela, um meio de valorizar essa população, durante muito tempo ignorada pelas classes dirigentes. Sabia revelar as fracturas da sociedade, mas sentia-se sempre nela o amor que tinha pelo seu país». ${ }^{8}$ Mas este livro, sem lugar para maniqueísmos, fala igualmente dos eternos conflitos entre os judeus, devido às suas origens muito variadas: os askhenazi (em português asquenazitas) judeus vindos da Alemanha e do norte da França no século XVII; depois, outros chegados da Europa de leste e da Rússia - fugidos ou expulsos durante o nazismo e os sefaradim (sefarditas, em português) vindos da Península Ibérica, durante as perseguições da Inquisição. E, finalmente, os orientais, mizrahim, do Iemen, do Iraque, do Oriente. As diferenças políticas, a variedade étnica, a convivência próxima com os árabes tornam Jerusalém um «melting pot» onde tudo ferve intensamente - e que Batya Gur retrata com muita sensibilidade e humanismo.

No romance Bethlehem Road Murder: a Michael Ohayon mystery, a vítima é uma jovem iemenita, Zahara Bashari, assassinada no terraço de um prédio em reconstrução, na encruzilhada do caminho para Belém, à saída de Jerusalém. Encontram-na, desfigurada, sem mala de mão nem qualquer documento, e identificá-la torna-se tarefa difícil. Vestida como se fosse para uma festa, com roupas e sapatos de marca, bem maquilhada, de cabelos pintados e bem arranjados - tem o rosto completamente desfeito por um instrumento contundente, possivelmente uma pedra das muitas que existiam naqueles prédios.

\footnotetext{
${ }^{7}$ As origens dos judeus são muito variadas: sefarditas, asquenazitas, orientais (mizrahi). Neste caso, refere-se ao grande êxodo de judeus de Marrocos, em 1969, onde se tinham estabelecido desde os tempos da Inquisição e onde se sentiam seguros. Mas o receio, depois de alguns ataques contra a comunidade, provocou uma fuga em massa para Israel.

${ }^{8}$ Cf. Le Monde, 23 Maio, 2005 (minha tradução). Ziva Avran é professora de Literatura Hebraica no Departamento Hebraico da Universidade de Lille III.
} 
O conflito surge entre a comunidade étnica dos iemenitas - que estão a preparar uma festa na Sinagoga «à maneira tradicional iemenita» - e a dos askhenazi que não aceitam que, no coração da Cidade Santa, possa existir uma comemoração dos judeus orientais. O que revela, segundo os iemenitas, discriminação e falta de respeito em relação à sua cultura. O assassínio «desloca-se» da periferia, para o centro de Jerusalém, porque era onde a jovem Zahara Bashari vivia e onde estava a organizar essa festa. O irmão, Netanel Bashari, só começa à sua procura dois dias depois do desaparecimento. Não se preocupara antes e explicava: «com a Zahara e a sua mania da independência, nunca sabemos por onde anda». Ao saber da sua morte, fica em choque. Quando Ohayon o interroga, a única coisa que consegue dizer é: «Não posso acreditar... Zahara era a criatura mais cheia de vida que eu conheço!» E continuava a repetir: «Não havia ninguém com tanta vida como ela» (idem: 123-124; minha tradução). Na mesma rua vivia Nessia, uma adolescente que admirava Zahara. Sempre que lhe era possível, punha-se à janela a espreitá-la, por detrás das cortinas. Desejava tanto ser como ela! Observa-a, vê quando sai e quando entra, as companhias, os carros em que entra. O que sabe dela um dia vai pôr-lhe a vida em perigo.

Ao longo da narração, vêm à superfície as relações turvas entre os palestinos que vivem na Cisjordânia e os judeus. Nota-se no modo como os palestinos são tratados por alguns agentes da Polícia, em que a presunção de culpa parece formada desde o início. Ohayon encontra-se em desacordo com as práticas «selectivas» do inspector Danny Bality ou do sargento Eli Bashar e, por vezes, há conflitos e discussões. Entre as pessoas presentes na descoberta do corpo de Zahara encontram-se a jornalista Orly Sushan e Ada, antiga namorada de Michael, que protestam contra essa atitude.

A escritora consegue um equilíbrio extraordinário ao falar destes assuntos melindrosos. Aborda de modo claro os assuntos complicados e controversos da sociedade israelita. Fala dos casos graves que se escondem nos mundos fechados ou comunitários - dentro de uma classe social ou filosófica ou literária, ou musical, ou religiosa. Grupos com características muito diversas, que vivem isolados, ensimesmados, os «insulares».

O último livro de Batya Gur, Murder in Jerusalem: a Michael Ohayon mystery (2006), é publicado postumamente. O título algo banalizado «Crime em directo» foi escolhido por algumas traduções - mas importa sublinhar que, no original, demarca um território e destaca o protagonista. Como é seu costume, a autora alia a intriga policial à análise psicológica. A acção passa-se na sede da Televisão 
talvez uma das mais complicadas que tivera, muito melindrosa devido às personalidades públicas que estão implicadas.

A conclusão do livro é bastante crítica para certos responsáveis políticos e deixa Michael Ohayon num dilema que não quer resolver. Possivelmente esse dilema teria sido «aprofundado» - e concluído - no romance que Batya Gur viesse a escrever. O que diria ela do que resta, em Israel, do sonho «sionista»? Para onde vai Israel? Ela teria tido uma palavra a dizer. Pela via da ficção policial, deu a conhecer e divulgou pelo mundo fora muitos dos problemas de Israel. Uma forma de intervenção que fez com dignidade e com imparcialidade. Porque o que lhe interessava verdadeiramente era a natureza humana, quer nos seus conflitos quer na sua ânsia de beleza quer na capacidade de generosidade. Nas suas contradições, em suma.

\section{Bibliografia}

GUR, Batya (1994), Murder on a kibutz: a communal case, HarperCollins Publishers. (1999), Murder Duet: a musical case, HarperCollins Publishers. (2002), o Assassínio de Sábado de Manhã: um Caso Psicanalítico, editora Relógio d’Água, tradução de Fernanda O’Brien (The Saturday Morning Murder, 1992). (2004), The Literary Murder: a critical case (1993), HarperCollins Publishers. (2004), Betlehem Road Murder: a Michael Ohayon mystery, HarperCollins Publishers. (2006), Murder in Jerusalem: a Michael Ohayon mystery (póstumo), HarperCollins Paperbacks.

MALKA, Victor (1991), Les Juifs Sépharades, Presses Universitaires de France, col. Que sais-je?. OZ, Amos (1994), Israel, Palestine and Peace, ed. Vintage. (2004), Une histoire d'amour et de ténèbres, Gallimard, Folio.

SHAVIT, Ari (2013), La mia terra promessa, Sperling\&Kupfer (My Promised Land, Mapping Specialists Ltd).

\section{Links}

https://www.larioja.com/culturas/201408/17/batya-agatha-christie-israel-20140817002221-v.html https://www.haaretz.com/1.4844189 https://www.lemonde.fr/disparitions/article/2005/05/23/batya-gour-ecrivaine-israelienne_652941_3382.html 


\section{Patrícia Melo e a reconfiguração do policial brasileiro}

Mariana Cepeda

É possível observar o crescimento do número de obras policiais de autoria de mulheres nas últimas três décadas no Brasil. ${ }^{1}$ Contudo, as escritoras estão presentes nesse gênero literário desde 1944, embora Patrícia Galvão, a primeira escritora brasileira a se aventurar pelas narrativas policiais, tenha usado um pseudônimo masculino e estrangeiro (King Shelter). Em junho de 1949, quase 30 anos após a publicação em capítulos da narrativa 0 mistério, considerada a primeira ficção policial brasileira, Dinah Silveira de Queiroz se tornou a primeira mulher a assinar abertamente uma novela policial. Denominada 0 homem das 3 cicatrizes, a narrativa foi escrita por Queiroz e mais nove escritores e também foi lançada em capítulos, no jornal A Manhã. ${ }^{2}$

Desde então, outras mulheres participaram da construção do gênero policial no Brasil, como Lúcia Machado de Almeida e Maria Alice Barroso, nas décadas de 1950 e 60, e Sonia Coutinho e Elvira Vigna, a partir do fim dos anos 1980. É na década de 1990 que se observa um boom de obras policiais no país e um crescimento exponencial de mulheres no gênero, dentre as quais se destaca a escritora paulista Patrícia Melo.

Melo é autora de onze obras literárias e de uma série de roteiros para teatro, televisão e cinema. Publicou entre 1994 e 2017 um livro de contos, Escrevendo no escuro (2011), e dez romances, nomeadamente, Acqua toffana (1994), 0 matador (1995), Elogio da mentira (1998), Inferno (2000), Valsa negra (2003), o mundo per-

\footnotetext{
${ }^{1} \mathrm{Na}$ dissertação de mestrado, Fogo-fátuo? Mulheres detetives na ficção policial brasileira (2017), apresentei com mais detalhes a participação das mulheres na literatura policial do Brasil como autoras, e principalmente como personagens. O presente artigo apresenta algumas discussões também feitas na referida dissertação. Disponível em: https://repositorio-aberto.up.pt/handle/10216/109345

${ }^{2}$ Para uma cronologia da literatura policial brasileira, com títulos publicados até janeiro de 2005, ver Reimão (2005: 51-62).
} 
dido (2006), Jonas, o copromanta (2008), Ladrão de cadáveres (2010), Fogo-fátuo (2014) e Gog Magog (2017).

A maior parte das suas obras também foi lançada no mercado português pela Campo das Letras e pela Quetzal Editores. Apenas o seu livro de contos e os seus dois romances mais recentes ainda aguardam publicação em Portugal. Além disso, várias de suas obras já foram traduzidas e lançadas em outros países europeus, como França, Alemanha, Itália, Espanha, Holanda, Grécia, Finlândia e Inglaterra. Seu trabalho como escritora tem sido reconhecido não apenas no Brasil, onde ela ganhou o Prêmio Jabuti, em 2001, por Inferno, como também internacionalmente, tendo recebido prêmios na Europa, como o francês Deux Océans e o alemão Deutscher Krimi.

As narrativas de Patrícia Melo têm componentes que, segundo afirma Karl Eric Schøllhammer, em Ficção brasileira contemporânea (2009), destacam-se no Brasil em diversas ficções a partir da década de 1960, em grande parte graças a Rubem Fonseca e à sua prosa brutalista: ${ }^{3}$ a violência social no submundo dos centros urbanos brasileiros, perpetrada por sujeitos marginalizados, mas em grande parte relacionada com figuras de classes sociais mais altas. Assim como Fonseca, Patrícia Melo explora esse universo por meio de uma linguagem direta e coloquial, que constrói um «realismo cruel» (Schøllhammer 2009: 27).

Ao mesmo tempo, Melo é herdeira e intensificadora do hibridismo literário que, como afirma Schøllhammer, se destacou na prosa da década de 1980 , como resultado da interação entre vários meios de comunicação - principalmente os visuais - e a literatura. A escrita de Melo, que Schøllhammer chama de roteirizada, pois próxima à forma narrativa do cinema, com cortes, flashes e um ritmo acelerado, explora a intensificação desses elementos especialmente nos dois romances com protagonistas de classe social baixa que se tornam assassinos, ressaltando o ambiente caótico e de constante violência em que vivem. Isso pode-se verificar, por exemplo, no trecho de Inferno em que o protagonista Reizinho, uma espécie de flâneur da periferia, ${ }^{4}$ caminha pela favela onde mora, na cidade do Rio de Janeiro.

\footnotetext{
${ }^{3}$ Alfredo Bosi é quem começa a usar esse termo, em sua obra História concisa da literatura brasileira, na qual insere Rubem Fonseca na linha do «brutalismo ianque» (Bosi 2015: 466).

${ }^{4}$ O flâneur, segundo a leitura que Walter Benjamin faz de Charles Baudelaire em «A Paris do Segundo Império» (1938), é um indivíduo que percorre a cidade, sem rumo, e busca observar e conhecer o espaço urbano e os desconhecidos que por ele transitam (1938: 69).
} 
Durante a caminhada morro acima, domésticas sorriem para ele, passam, crianças, gente indo para o trabalho, oi Reizinho, pedreiros, cumprimentam, crianças, cachorros, eletricistas, oi, acenam as mãos, latem, cadelas, babás e digitadores, cachorros, encanadores, gigolôs, porteiros, ladrões de carros, crianças, sorriem, moças nas janelas, manobristas, assaltantes, costureiras, sorriem, traficantes de armas, o local é tumultuado, crianças, lamentos, é barulhento, confuso, entulhado, sujo e colorido. (Melo 2003: 10)

As personagens flâneurs de Melo, bem como as de Rubem Fonseca, devem muito ao escritor brasileiro João do Rio, autor-flâneur que, no início do século XX, percorreu e descreveu as ruas do Rio de Janeiro, apontando o que ficou à margem do progresso; aquilo que Marta Passos Pinheiro, no artigo «A alma encantadora das ruas: o cronista-flâneur no avesso da cidade» (2012), denomina o «Rio subterrâneo», «o avesso da cidade» (2012: 67). No entanto, também o detetive das ficções policiais costuma ser visto como um flâneur, uma figura marginal, mas atenta e perspicaz, que observa a vida urbana - a qual, devido ao seu aspecto ameaçador, está «na origem da história de detetive», como afirma Walter Benjamin (1938: 69). ${ }^{5}$

\section{A herança policial e a herança fonsequiana}

Rubem Fonseca costuma ser classificado como um autor de literatura policial, embora em poucos romances ele, de fato, se aproxime das técnicas mais clássicas desse gênero (Reimão 2005: 43). Por outro lado, é clara a importância do policial hard-boiled para as obras fonsequianas, que geralmente têm como foco a realidade marginal e os criminosos dos grandes centros urbanos, mas também «a dimensão mais sombria e cínica da alta sociedade» (Schøllhammer 2009: 27). O policial hard-boiled - policial americano ou policial noir, como ficou conhecido em português (Reimão 2005: 11) -, retoma a brutalidade da ficção criminal de

\footnotetext{
${ }^{5}$ Além do êxodo rural brasileiro, a partir de meados do século XX, o qual, em cinquenta anos, transformou um Brasil rural em um país que concentra quase $80 \%$ da sua população em áreas urbanas, outras mudanças a partir dos anos 1960 também contribuíram para que a literatura policial se consolidasse no país, por meio das obras de Rubem Fonseca (Schøllhammer 2009: 22). De acordo com Tânia Pellegrini, a introdução do Brasil no circuito do capitalismo avançado, a industrialização crescente, o crescimento e a deterioração dos grandes centros urbanos e o aumento do crime fizeram com que a violência se tornasse a protagonista da ficção brasileira urbana a partir da década de 60 , ao lado das críticas à ditadura militar (Pellegrini 2004: 19).
} 
muitas autoras e autores no Brasil também o são. ${ }^{10}$ A relação de Patrícia Melo com Fonseca vai além da influência que a literatura desse ficcionista teve sobre a dela, já que ele promoveu pessoalmente o trabalho da autora. Além disso, os dois trabalharam juntos em alguns projetos e Fonseca foi responsável pela adaptação de 0 matador para o cinema. No entanto, segundo Ostrom, Melo faz uso de uma estratégia que pode ser observada desde o início do gênero policial: ao mesmo tempo que homenageia Fonseca, bem como outros nomes do policial, ela marca as suas próprias diferenças e, em alguns casos, deixa críticas aos seus antecessores. Para Ostrom, é quando mais se aproxima de Fonseca, apropriando-se de suas narrativas e personagens, que Melo acentua mais fortemente a sua diferença em relação a esse pai literário, desvelando ainda questões problemáticas de gênero e classe que não ganharam enfoque nas obras de Fonseca.

Em 0 matador, a influência fonsequiana fica bastante clara no trabalho de Patrícia Melo. Ela usa até mesmo uma personagem do autor, o dentista Dr. Carvalho, do conto «O cobrador». Katherine Ann Ostrom afirma que a narrativa de 0 matador pode ser vista como uma reescrita e uma expansão do conto de Fonseca (Ostrom 2011: 118). Ao contrário de «O cobrador», no entanto, Patrícia Melo mostra como a desigualdade social, somada a discursos normativos que envolvem gênero, sexualidade, raça e classe social, contribuem para o percurso de crescente violência do protagonista. ${ }^{11}$

Como afirma Pere Comellas, no artigo «Rubem Fonseca e o policial noir» (2014), os contos de Fonseca costumam adentrar o submundo carioca a partir dos marginalizados, enquanto nos romances do autor a voz costuma ser de homens de classe média e não mais a dos despossuídos, mesmo que estes não sejam deixados de fora (2014: 61). Ainda que minorias estejam presentes nos romances de Rubem Fonseca e seus protagonistas muitas vezes se posicionem contra diferentes formas de discriminação, o homem branco, hetero e de classe média permanece não apenas como o herói da narrativa, mas também como a voz que orquestra e explica os seus eventos. Como nota Ostrom, personagens como o investigador Mandrake e o escritor Gustavo Flávio, de Bufo \& Spallanzani, permanecem a «single voice taking control of a complicated narrative» (2011: 55).

\footnotetext{
${ }^{10}$ Patrícia Melo presta homenagem a Rubem Fonseca em vários romances, comoJonas, o Copromanta e Elogio da mentira. Este último é, inclusive, dedicado ao escritor.

${ }^{11}$ É principalmente sobre questões de gênero e de classe social que as narrativas de Melo constroem suas críticas sociais. Embora a raça seja um elemento que perpassa em algumas das suas obras e críticas ao racismo no Brasil, essa questão não recebe a mesma atenção que as outras duas. Em relação à orientação sexual das personagens, ver a nota 21 deste artigo.
} 
A maior parte das obras de Patrícia Melo também tem como eixo a vivência de personagens homens, brancos, heteros e de classe média. Apenas em 0 matador e Inferno, a narrativa se desenvolve em torno de personagens de classe baixa. Embora o primeiro romance de Melo, Acqua toffana, conte com duas personagens principais: uma mulher, na primeira metade da narrativa, e um homem na segunda; quase todas as suas obras subsequentes trazem protagonistas homens. A exceção é Fogo-fátuo, romance do qual trataremos mais adiante. No entanto, como veremos, os protagonistas homens de Melo são muito diferentes dos detetives de Fonseca e dos heróis do policial hard-boiled. Elena Losada Soler nota também que as representações femininas de Melo são «más facetadas - y tratadas com más piedad - que los personajes femeninos de Rubem Fonseca» (Losada Soler 2014: 22). Embora geralmente secundárias, as personagens mulheres são muito relevantes para as narrativas de Patrícia Melo e, frequentemente, fazem um contraponto importante ao anti-herói, o que discutiremos com mais detalhes no último tópico deste artigo. A maior parte dos criminosos de Melo também ganha voz e conhecemos o seu mundo interior, ao longo do romance. Especialmente nas obras protagonizadas por jovens de classe baixa, essas personagens são apresentadas de forma complexa e, em alguns momentos, é possível criar empatia e até uma identificação com esses criminosos.

\section{O monstro que vive em nós - e na sociedade}

Os criminosos de Melo não são «bons bandidos», bandidos sociais ou malandros, mas tampouco são psicopatas sem remorso ou vilões sub-humanos apresentados em esquemas maniqueístas que retiram a culpa da sociedade. ${ }^{12} \mathrm{Com}$ a exceção dos criminosos de Acqua toffana e Fogo-fátuo - curiosamente as obras que apresentam protagonistas mulheres -, nas quais de fato pouco vemos dos assassinos para além da sua monstruosidade, os criminosos de Melo são apresentados de forma complexa.

Em obras como Elogio da mentira, Ladrão de cadáveres e Gog Magog, Melo parece defender a tese de que todos, de qualquer gênero, raça e classe social, somos criminosos em potencial e de que ninguém está completamente imune ao crime,

\footnotetext{
${ }^{12}$ Sobre os «malandros» na literatura brasileira, ver Schøllhammer (2001). Em relação à demonização do criminoso e à forma como ele é apresentado em diversas narrativas como bode expiatório que absolve a sociedade da sua cumplicidade no crime, ver Plain (2001).
} 
seja como algoz, seja como vítima. No início da narrativa de Ladrão de cadáveres, o protagonista e narrador acredita que se encontra a salvo do caos do qual escuta falar na rádio, caos que o tranquiliza por estar distante dele. «Ouço tudo com a sensação boa de que não sou alvo de nada, estou fora das estatísticas, não sou rico, não sou preto nem muçulmano, é isso que penso, estou salvo (...)», afirma (Melo 2010: 3). Porém, ao tentar salvar a vida de um homem, o protagonista envereda pelo caminho da ilegalidade, tornando-se cada vez mais imerso no submundo do crime. A narrativa evidencia, assim, que a maldade já nasce connosco, «como um vírus inativo, que apenas espera o momento de aflorar» (idem: 9). No entanto, a partir dos discursos dos protagonistas criminosos de Melo, vislumbramos elementos que parecem instigar o afloramento desse vírus, dentre os quais se destacam o caos urbano, a sensação de não-pertença e de impotência dos indivíduos, bem como a necessidade de se conformarem à masculinidade hegemônica, sobre a qual falaremos mais adiante.

Em Gog Magog, a propensão à violência parece se intensificar no ambiente urbano, onde as relações humanas e a capacidade de empatia se enfraquecem, assim como a noção de pertencimento a uma comunidade. O vizinho do morador urbano se torna mero objeto produtor de poluição sonora. O protagonista e narrador da obra, um professor de biologia que acaba assassinando o vizinho, defende-se afirmando que não via a sua vítima como um ser humano e que os barulhos constantes provocados pelo outro foram responsáveis por uma reação meramente biológica, um ódio «fabricado por enzimas», que o levava a vê-lo como mero «emissor de ruídos variados (...). Sem conteúdo» (Melo 2017: 111). Na vida do protagonista, as pessoas perdem a sua condição de sujeito, o que é expresso pela forma como ele nomeia aqueles que considera os seus antagonistas: senhor Ípsilon; Dr. Odiável; «o negro» (idem: 109).

Porém, a narrativa também explora outros fatores sociais que contribuem para a decadência do protagonista, um professor que enfrenta vários problemas na carreira: o baixo salário como funcionário da rede pública, o desrespeito e as agressões de estudantes e até mesmo a crescente dificuldade de ensinar ciência a alunos que preferem acreditar em líderes religiosos. Por trás disso, o descaso do governo em relação às escolas públicas, levando os professores a iniciar uma greve. Sem qualquer autoridade perante os seus alunos, o protagonista se sente diminuído também em casa, onde a enteada precisa ajudar a pagar as contas. Além disso, o seu casamento não vai bem e ele frequentemente escuta ofensas da esposa, que acaba trocando-o por outro homem. 
objetivos urgentes: Reizinho quer parar de usar drogas e escapar do caminho trilhado por seu pai alcóolatra; Máiquel quer tratar sua dor de dente e, para isso, aceita assassinar um homem a pedido do dentista. Em seguida, a carreira no crime se torna uma maneira de ambos se afirmarem em suas comunidades, de se sentirem menos impotentes e de ascenderem socialmente. Reizinho, por exemplo, não quer ser nem como o pai, nem como a mãe, uma mulher honesta e trabalhadora, mas que é explorada e humilhada pela patroa. Na favela onde mora, a sua referência - tanto de sucesso, como de masculinidade - é o traficante Miltão.

Em 0 matador, o Dr. Carvalho é um homem da classe média que se torna uma espécie de mentor - e explorador - do protagonista Máiquel, que se transforma em assassino de aluguel. Ao serviço da segurança e dos objetivos econômicos de Carvalho e seus amigos, Máiquel coloca em prática, com as próprias mãos, os ideais de justiça e de pena de morte defendidos por uma parcela da classe média, representada pelo dentista e seu grupo. ${ }^{14}$ Apresentada em primeira pessoa e no passado, a narrativa de 0 matador traz reflexões de um protagonista ciente dos seus erros e da sua ignorância ao aceitar a proposta de Dr. Carvalho, o dono de sapatos engraxados e elegantes que Máiquel tanto desejava. A namorada do jovem, Érica, alerta-o, ao longo da narrativa, das intenções do dentista e dos perigos que o matador da periferia corre, comparando-o a pilotos-suicidas. «Eles querem que você faça o inimigo explodir, só que você vai ter que explodir junto (...)», afirma ela (Melo 1995: 88).

Máiquel e Reizinho são construídos tanto como criminosos, quanto como vítimas da injustiça social, já que poucas oportunidades são oferecidas a esses jovens de periferia para que escapem do mundo da criminalidade. No entanto, dentre as críticas sociais que perpassam as narrativas de Melo e a forma como a autora constrói suas personagens, destaca-se principalmente a desconstrução das normas da masculinidade hegemônica e a desaprovação do machismo e da misoginia na sociedade brasileira. ${ }^{15}$

\footnotetext{
${ }^{14}$ Segundo Carlos Alberto Faraco, em «O matador de Patrícia Melo: uma abordagem bakhtiniana» (1998), a linguagem social de Dr. Carvalho se estrutura em torno de alguns enunciados básicos, como «a violência está cada vez pior» (Melo 1995: 30), «essa história de direitos humanos é uma piada» (ibid.), «o problema desses meninos é que a polícia prende e a justiça solta» (idem: 92). O dentista também nega que a violência seja consequência da pobreza e, em vez disso, defende explicações biológicas. ${ }^{15}$ Construída, reconstruída e legitimada pelo senso comum, pela cultura de massa, por instituições sociais, como a Igreja, e até mesmo por discursos de diferentes campos do conhecimento, como a sociobiologia, a masculinidade hegemônica é, segundo afirma a autora R. W. Connell, apresentada
} 


\section{Desconstruindo a masculinidade hegemônica}

A crítica à masculinidade hegemônica, ao machismo, à misoginia e à violência contra as mulheres são pontos centrais de muitas das obras de Patrícia Melo, dentre as quais podemos destacar Acqua toffana, 0 matador, Inferno e Fogo-fátuo. Como afirma Katherine Ann Ostrom, «Melo shows men’s and women's lives are ruined by the pressure on men to prove themselves at every turn, through violence, domination, and control of women» (2011: 80). Cláudia Castanheira, ao analisar 0 matador, também afirma que a ficção de Melo apresenta personagens masculinas desajustadas e extremamente machistas. Segundo a autora, «Patrícia Melo abusa do sistema de dominação masculina para desqualificá-lo» (2010: 248).

A desconstrução da autoridade do protagonista homem e da masculinidade hegemônica contribui para que a autora subverta um gênero frequentemente considerado conservador e falocêntrico e que, no Brasil, é fortemente marcado por um autor homem: Rubem Fonseca. ${ }^{16}$ A restauração da ordem e do status-quo, o individualismo e o enaltecimento de comportamentos e valores culturalmente associados ao masculino, ao lado da estereotipificação e objetificação de figuras femininas, são elementos que se destacam ao longo da história da ficção policial e podem ser encontrados em muitas obras canônicas do gênero.

Contudo, como afirmam Priscilla Walton e Manina Jones, no artigo «Sim ou não? A problemática da narrativa de detecção feminina» (2012), o gênero literário serve como «lugar relacional, convencional e contraditório» (2012:132), cuja consolidação, mas também reconstrução, dependem da crítica, do cânone e dos leitores - e, podemos adicionar, das editoras e do mercado. Walton e Jones defendem que as escritoras feministas que se apropriam da literatura policial operam por dentro da estrutura patriarcal da sociedade ocidental, ao mesmo tempo que operam contra ela, enquanto expõem as normas e convenções dos discursos dos quais se apoderam. Na obra Murder by the Book? (1994), Sally Munt

como fixa, como uma «masculinidade verdadeira» que expressa a essência do homem e do corpo masculino (Connell 2005: 45-6). Tal masculinidade é associada a certos valores e comportamentos, como a agressividade, o desejo sexual incontrolável, a heterossexualidade, a dominância, a competitividade, etc.

${ }^{16}$ Em relação aos elementos conservadores na ficção policial, ver Porter (1981). Para um debate aprofundado sobre o caráter falocêntrico desse gênero literário, ver Munt (1994). Uma autora que defende que o policial é um gênero «masculino»e, portanto, inadequado para uma literatura feminista é Klein (1988). 
afirma que, desde o surgimento do policial, as mulheres se infiltraram nessa literatura e «feminilizaram» a sua forma por meio de uma série de estratégias, como o humor, a paródia e a desestabilização da autoridade masculina (Munt 1994: 5). Estratégias que estão muito presentes nas obras de Patrícia Melo.

É de forma irônica que Melo ataca a autoridade e a virilidade dos seus protagonistas, como na passagem de 0 matador para a qual Losada Soler chama atenção: «(...) Ezequiel continuava vivo, meus braços doíam, espetei a lança de madeira no coração do estuprador, eu já tinha visto esta cena na televisão, a mocinha matando vampiro (...)» (Melo 1995: 48-9). Melo desestabiliza, nesse trecho, duas oposições que a literatura policial - mas não apenas ela - tem explorado fortemente: herói/criminoso e homem herói/mulher indefesa. ${ }^{17}$ Máiquel parece se afirmar como um herói, que derrota o monstro, o estuprador. No entanto, ele próprio também cometeu um estupro, o que evidencia que a sua posição varia entre o herói que ele acredita ser e o monstro que a sociedade virá a crer que ele é. Em segundo lugar, Máiquel se compara a uma «mocinha» e não a um herói, embora, ao longo de toda a narrativa, ele busque constantemente se afirmar por meio das suas relações sexuais e dos seus crimes como um homem enquadrado nas normas da masculinidade hegemônica. Como nota Losada Soler, ele é um criminoso com aspirações a «macho alfa», enquanto, ao mesmo tempo, tem uma mocinha como modelo (Losada Soler 2014: 18).

Nas obras de Melo, as personagens masculinas estão constantemente em busca de se adequar ao ideal da masculinidade hegemônica, mas frequentemente falham. Em alguns casos, a narrativa zomba da ilusão dessas personagens, bem como das suas tentativas falhadas. Em 0 matador, por exemplo, Érica interrompe as fantasias de onipotência do protagonista de forma abrupta, quando ele a observa nua no banho. Se Máiquel a princípio está sobre uma escada, ou seja, em um patamar superior, e o seu olhar ativo objetifica o corpo nu e vulnerável de Érica, por outro lado, quando ela o derruba da escada, não apenas a fantasia voyeurística do protagonista é interrompida, mas ele também é jogado no chão e colocado em um nível inferior. É justamente enquanto Máiquel pensa na supe-

\footnotetext{
${ }^{17}$ É importante ressaltar que a ambivalência da oposição criminoso/herói ou, mais especificamente, criminoso/detetive já está presente, ainda que de forma sutil, em muitos detetives de narrativas canônicas do gênero policial. Lee Horsley nota que um lado sombrio ameaça a identidade de vários detetives mais tradicionais, pois, para restaurar a ordem, eles precisam «entrar na mente perturbada do criminoso» (Horsley 2009: 28). Holmes pode ser visto, de acordo com a autora, como uma figura pela qual se explora «a variety of subversive identities - the different facets of contemporary anxiety and the variety of selves that can be contained within the modern individual» (idem: 31).
} 
rioridade masculina que Érica e a narrativa desconstroem bruscamente, e com humor, a masculinidade hegemônica que ele defende, como é possível ver no seguinte trecho: «o homem é forte, o homem conquista, o homem cria, o homem constrói, e de repente, craft, Érica puxou a escada, filho da puta, eu caí (...)» (Melo 1995: 76).

Em muitas narrativas de Melo, a busca incessante por se adequar à norma é o que leva os homens em direção ao crime e/ou à autodestruição. Como debatido anteriormente, a sensação de impotência dos protagonistas de 0 matador, Inferno e Gog Magog, bem como a ilusão de onipotência derivada do objeto fálico da arma de fogo com a qual entram em contato, são elementos vitais da decadência dessas personagens ao longo da narrativa. A sensação de dominância e virilidade que eles tiram tanto do assassinato, transformando o outro num objeto inerte, quanto da objetificação de mulheres, está relacionada à norma de masculinidade a qual desejam se conformar.

Em Fogo-fátuo, a inadequação do ator Fábbio à masculinidade hegemônica, expressa principalmente pela sua impotência sexual, leva ao deterioramento do seu casamento e à sua própria morte. Sempre que briga com a esposa, Cayanne, Fábbio a lembra de seu passado como garota de programa, chamando-a de "puta» (Melo 2014: 38), de forma a restaurar a inferiorização e objetificação da mulher, podendo voltar a ser, assim, um sujeito ativo frente ao corpo passivo da ex-prostituta. Ao se envolverem em uma relação sexual com um garoto de programa que os fotografa em momentos íntimos, o casal passa a ser chantageado e Fábbio decide se submeter ao chantagista, pois tem medo do que os outros podem pensar ao descobrirem que ele não se conforma ao espectro sexual visto como «natural»e «normal» pela sociedade. ${ }^{18}$ Por fim, ele novamente se recusa a procurar a polícia quando descobre que o criminoso da narrativa, Djavan, estava envolvido com uma rede de pedofilia, pois o outro ameaça revelar fotos que mostram Fábbio sendo violentado sexualmente. É essa ameaça dupla à sua masculinidade - pois as fotos o revelam não apenas em condição de vítima, mas de vítima sexual de outro homem - que faz com que Fábbio

\footnotetext{
${ }^{18}$ O espectro sexual «normal», segundo Gayle Rubin (1999), é definido a partir de diversos discursos - religiosos, médicos, políticos ou do senso comum - que constroem uma hierarquia sexual, a partir da qual apenas uma pequena porção das experiências humanas é considerada natural e «boa», enquanto é considerado anormal e «mau» o sexo caracterizado por um ou mais dos seguintes aspectos: fora do casamento, casual, não-procriativo, comercial, desacompanhado ou em grupo, homossexual, entre gerações distintas, em público, envolvendo pornografia ou objetos, sadomasoquista (Gayle 1999: 152).
} 
Érica, de 0 matador, por outro lado, usa tanto a sensualidade quanto a inteligência e a atividade para conquistar Máiquel e fazer com que ele lhe proporcione uma condição melhor de vida. Por outro lado, abandona-o quando considera que precisa fazê-lo. Além disso, ela pode ser vista como uma autoridade na narrativa, como a personagem que desvenda a história por trás dos crimes de Máiquel: ela apresenta os verdadeiros criminosos e os reais motivos que guiam os assassinatos cometidos pelo matador, que se torna uma mera arma nas mãos de Dr. Carvalho. Ainda que não seja a narradora, a voz de Érica permanece relevante mesmo quando ela já abandonou o protagonista, como detentora de uma verdade que Máiquel passou a aceitar. No final da narrativa, arrependido de suas ações, o narrador resume a sua situação imaginando o que Érica diria: «você se deu mal porque ficou aí, dando sopa para aqueles caras» (Melo 1995: 202).

A agência de personagens femininas parece se consolidar quando elas se livram, de forma deliberada e ativa, de um relacionamento amoroso heterossexual e/ou quando passam a usar armas semelhantes às dos homens e a se comportar como eles, evidenciando o machismo das estruturas de poder. A incorporação de comportamentos culturalmente associados ao universo masculino, como a agência individual e a agressividade, por heroínas mulheres é algo frequente na literatura policial das últimas décadas. Assim como as Amazonas, essas personagens absorvem características masculinas e deixam de necessitar de homens, pois, como afirma Sally Munt, tomam para si as suas capacidades e valores, para ganhar espaço e agência em uma sociedade patriarcal (1994: 41). Em personagens de grande sucesso na literatura policial internacional, como V. I. Warshawski, detetive criada pela autora norte-americana Sara Paretsky, e Lisbeth Salander, uma das protagonistas da trilogia do sueco Stieg Larsson, nota-se a importância da adoção de comportamentos socialmente masculinos - como a violência, a ação individual e o uso de armas - para o sucesso dessas detetives em suas empreitadas. Salander não apenas se mostra uma mulher viril por meio desses comportamentos, como a narrativa explicita a relação da detetive com o mito das Amazonas. Como nota Maria de Lurdes Sampaio, no artigo «Millennium Trilogy: An eye for an eye and the utopia of order in modern waste lands» (2011), Salander «has no breasts (in the first novel), she rides a bike (the closest replica of a horse in an urban setting), and she carries a taser to protect herself (both a 'sword' and phallic symbol)»(Sampaio 2011: 77). Além disso, no terceiro livro da trilogia de Larsson, Luftslottet som sprängdes (2007)/ The Girl Who Kicked the Hornets' Nest (2010), são inseridas informações sobre as Amazonas ao longo da narrativa. 
Embora Hans Bertens e Theo D’haen afirmem, na obra Contemporary American Crime Fiction (2001), que pode ser contraprodutivo para autoras feministas masculinizar as suas protagonistas, já que o empoderamento feminino passa justamente por desconstruir a conexão entre poder e masculinidade (2001:14-15), no caso das narrativas de Melo é possível afirmar que a autora evidencia a existência dessa conexão, ao mesmo tempo que a critica. Em Inferno, a personagem Marta é uma espécie de mulher fatal que se torna chefe do tráfico na favela fictícia da narrativa. Devido a isso, ela não apenas toma para si valores culturalmente considerados masculinos, como a autoridade, e abandona comportamentos tradicionalmente femininos que ela própria apresentava no início da narrativa, como vaidade e sensualidade, mas também passa a se travestir de homem e se referir a si mesma como «um cara» (Melo 2000: 335). Ela faz isso, como fica claro na narrativa, para amenizar a discriminação pelo fato de ser mulher. Dessa forma, Melo não somente expõe a importância que é dada aos valores e comportamentos associados ao universo masculino na hierarquia do tráfico - e a associação entre a violência e a brutalidade do submundo urbano e a masculinidade hegemônica -, mas também desvela o caráter performativo do gênero. Como afirma Judith Butler, na obra Problemas de gênero: feminismo e subversão da identidade (1990), a identidade de gênero se constrói pelo processo citacional e reiterativo da performatividade de gênero, que é, por sua vez, a repetição de convenções e a reiteração de um conjunto de normas cuja «citacionalidade» se torna dissimulada no processo. Para Butler, performances que ela vê como parodísticas, como as de drags, travestis e butches, operam, no lugar da coerência de gênero regida pela heterossexualidade, a desnaturalização de sexo e gênero, revelando implicitamente, ao imitar o gênero, «a estrutura imitativa do próprio gênero - assim como a sua contingência» (1990: 196). ${ }^{21}$

A maioria das personagens mulheres de Melo ganham complexidade e nuances que nos permitem identificar-nos com elas ou, ao menos, vê-las com

\footnotetext{
${ }^{21}$ Questões envolvendo a orientação sexual de personagens, assim como a discriminação contra sujeitos queer, não são abordadas de forma profunda, como acontece com o machismo e a misoginia. Contudo, Melo mostra como a constante tentativa das suas personagens homens de se adequarem à masculinidade hegemônica passa não apenas pela violência, pelo individualismo e pelo machismo, mas também pela repetição frequente de discursos e termos LGBTfóbicos, quase sempre homofóbicos. Termos como «veado» e «bicha» são mais constantes nas narrativas que se passam na periferia de cidades grandes, Inferno e 0 matador; mas também estão presentes em outras obras, dentre as quais se destaca Fogo-fátuo. Melo revela, assim, como tanto o submundo dos centros urbanos, quanto as instituições da lei e da ordem são dominados pelos ideais da masculinidade hegemônica e pela discriminação contra mulheres e indivíduos queer (mas especialmente homens gays).
} 
piedade. Elas também quebram com estereótipos que, em um primeiro momento, podem suscitar. A princípio, a narrativa de Fogo-fátuo, por exemplo, parece apresentar arquétipos femininos claros: Azucena, a mulher guerreira; Cayanne, a mulher fatal; Olga, a mãe e mulher cativa, que é também vítima. No entanto, Azucena se mostra tanto guerreira, quanto vulnerável. Ela é mãe e mulher fatal, detetive e vítima, sujeito e objeto. Cayanne, por sua vez, é inocente do assassinato do marido e, no seu relacionamento com ele, era mais vítima do que algoz. A sua construção como personagem alterna entre a condição de vítima e agente, entre a objetificação e a posição de sujeito. Quanto à Olga, descobrimos que ela não é mãe biológica da vítima e que tem atitudes violentas que não se adequam à figura da mãe bondosa e doce que, segundo Booker-Mesana, é a antítese da mulher fatal.

Em Fogo-fátuo, Patrícia Melo finalmente apresenta uma personagem mulher que protagoniza a narrativa e é a sua heroína. Se em Acqua toffana há uma espécie de detetive amadora - já que a protagonista da primeira parte da obra narra a um policial a forma como investigou o marido e descobriu que ele era um serial killer de mulheres -, essa detetive não tem qualquer autoridade e o seu relato não é levado a sério pela autoridade masculina do agente da polícia. Já em Fogo-fátuo, a voz da protagonista, a coordenadora do Setor de Perícias da Central Paulista de Homicídios, Azucena Gobbi, tem mais relevância e autoridade, mas também encontra resistência e machismo dentro da corporação policial.

A protagonista de Fogo-fátuo se assemelha, em muitos pontos, aos detetives - e às detetives que surgem a partir dos anos 1970 - do policial hard-boiled norte-americano. Como Phillip Marlowe, de Raymond Chandler, ela é uma heroína «sem medo e ainda com aura» (Chandler 1944: 74), que percorre as ruas sombrias do crime urbano e está suscetível a ser afetada por ele, mas que não abre mão de seu código deontológico profissional. Mantendo uma certa agência individual dentro da instituição policial, devido ao machismo e à corrupção de colegas, Azucena assume de forma crescente ao longo da narrativa qualidades e comportamentos associados culturalmente ao universo masculino. Ela se afasta da maternidade, corta os cabelos, estabelece encontros sexuais casuais com um homem objetificado, que ela chama de «pênis descartável», e resolve invadir a casa do suspeito do caso investigado por ela - estabelecendo, assim, uma agência individual e desobedecendo aos procedimentos legais da polícia (Melo 2014: 207). Contudo, em vez de ser bem-sucedida, como um tradicional investigador privado do hard-boiled, Azucena é violentada sexualmente pelo criminoso e perde 
a sua agência e condição de mulher viril não apenas diante dele, mas também dos colegas, que veem as fotos do abuso e passam a olhá-la com pena, tratando-a como «uma viúva recebendo os pêsames» (idem: 132).

Desiludida com os valores e papéis femininos, que não conseguiu conciliar completamente com sua profissão, mas crítica da postura masculina, além de ciente da falibilidade da mesma, Azucena se encontra ainda como sujeito dividido, pois não se reconhece nas imagens do seu abuso sexual. Como foi dopada pelo criminoso, não se lembra de nada e apenas se enxerga objetificada e abusada nas fotos que o violador tirou do abuso. Perdida num entre-lugar, pois não «Mulher», nem «Homem», não detetive-herói, nem vítima, a autoconstrução e reconstrução de Azucena parece apontar para um futuro, uma redescoberta a ser feita, que combina com o fato de Patrícia Melo ter anunciado mais duas obras a serem protagonizadas pela personagem e nas quais, segundo a autora, a narrativa de Azucena se tornará cada vez mais feminista. (Melo apud Silva \& França 2016: 254).

Da narrativa de 1994, Acqua toffana, para a de 2014, Fogo-fátuo, muitas coisas parecem continuar iguais. Embora Azucena desfrute de certa autoridade dentro da instituição policial e a sua voz tenha muito mais relevância que a da protagonista de Acqua toffana, ela ainda sofre discriminação por ser mulher e é marginalizada em diversas situações. Azucena é deixada de fora de uma das investigações mais importantes da central em que trabalha, o que ela percebe como machismo, "como se ela fosse incapaz e precisasse ser protegida» (Melo 2014: 235). Ao questionar um colega sobre a sua exclusão do caso, ele confirma a sua percepção, ao responder: «Porra, mocinha, você ia ficar banguela. Eles iam fazer uma cirurgia expressa nesse seu narigão» (idem: 235). Embora Azucena seja uma policial competente e tenha investigado por conta própria algumas das pistas relacionadas ao referido caso, ela não é vista pelos colegas homens como uma agente, como eles, mas como uma mocinha.

Ao mesmo tempo, em Fogo-fátuo também ocorrem crimes muito semelhantes aos que acontecem em Acqua toffana - o estupro e assassinato em série de mulheres, que têm os seios mutilados pelo serial killer. Se na primeira narrativa de Melo a versão da protagonista sobre esses crimes contra mulheres não é ouvida, em Fogo-fátuo as mulheres também são silenciadas. Azucena é a única a dar a devida importância aos crimes, mas não é ouvida pelo detetive responsável pelo caso, que não se esforça para resolvê-lo rapidamente. Já as vítimas, recebem pouca atenção não apenas da polícia, mas também da mídia, que prefere dar enfoque ao assassinato de um ator famoso. 
Como já mencionado, a própria Azucena sofre violência sexual, no final da narrativa. Embora outros detetives do policial hard-boiled sejam frequentemente atingidos pela desordem do ambiente urbano violento e, muitas vezes, sofram no corpo essa violência, o estupro de Azucena demarca uma condição específica, a vulnerabilidade a uma violência sofrida quase que exclusivamente por mulheres e na qual a condição feminina de opressão e objetificação na sociedade patriarcal é levada ao extremo. ${ }^{22}$ A violência sexual é, de certa forma, uma tentativa de reinserção da mulher na posição inferior de binômios hierárquicos - como alma/corpo, sujeito/objeto ${ }^{23}$ - e no papel sexual/reprodutivo ao qual ela é limitada pelo patriarcado. Como defende a própria Patrícia Melo, em entrevista, «o estupro, na história, é a forma como a nossa sociedade machista tenta colocar Azucena no 'seu lugar de mulher'» (apud Silva \& França 2016: 254).

Em 0 matador, a violência sexual contra uma mulher é explorada a partir do ponto de vista do protagonista homem, Máiquel. Na passagem em que ele estupra a namorada Cledir, fica clara a associação entre humilhação, poder e violência sexual. Se a narrativa de forma geral mostra a forma como a sensação de impotência, a humilhação e o ódio levam o protagonista ao papel de matador, algo semelhante se observa na sua transição para estuprador. Quando Cledir chega em sua casa e descobre que ele possui um porco, Máiquel sente-se humilhado, porque, segundo ele, «as pessoas não têm porcos em casa» (Melo 1995: 28). Isso desestabiliza o protagonista, pois seu percurso se trata justamente de uma busca por ser um indivíduo considerado «normal» ou «neutro»: um homem branco, hetero e de classe média, como Dr. Carvalho e seus amigos. Seus sapatos velhos são a marca da sua inferioridade diante dos homens de sapatos novos e engraxados, e é justamente o sapato de Máiquel que o porco estraga - o que Cledir nota e comenta. Quando a namorada se despe e se oferece a ele, o protagonista admira o seu corpo, mas recusa a relação sexual. A sua reação provavelmente resulta não apenas de se sentir humilhado pelo sapato e pela presença

\footnotetext{
${ }^{22}$ Como afirma Klein, o próprio uso em inglês do termo «male rape» - no lugar de apenas «rape» quando a vítima se trata de um homem, indica o quão anômalo é este crime quando não cometido contra mulheres (Klein 1995: cap. 12, local 3781-3782, para. 21).

${ }^{23}$ A distinção ontológica entre alma e corpo, que se iniciou na filosofia de Platão e foi reforçada ao longo da tradição filosófica ocidental, especialmente por Descartes, levou a associações culturais entre alma e masculinidade e entre corpo e feminilidade, sustentando «relações de subordinação e hierarquia políticas e psíquicas» (Butler 1990: 32). Outros binômios hierárquicos derivam desse primeiro, como sujeito/objeto, cultura/natureza, atividade/passividade, público/privado e racionalidade/irracionalidade.
} 
do porco, mas também por ter sido retirado da posição de sujeito ativo, diante da atividade de Cledir. É somente quando Máiquel a rejeita e ela começa a chorar, que ele passa a se sentir novamente em uma posição superior e, então, começa a desejá-la. Quando ela tenta fugir dele e chora ainda mais, isso alimenta o desejo de Máiquel, que se sente novamente o sujeito ativo diante da mulher objetificada, o conquistador que afirma seu poder e posse por meio do domínio de um território. $^{24}$

Embora muitas personagens de Melo sejam, acima de tudo, vítimas, como é o caso de Alzira e Carolaine, de Inferno, e Cledir, de 0 matador, podemos conhecê-las ao longo da narrativa e nos sensibilizarmos com sua situação, bem como condenarmos as condições sociais que as colocaram na posição em que se encontram. Embora outras vítimas das narrativas de Melo, como as mulheres assassinadas de Acqua toffana e Fogo-fátuo, sejam corpos mudos e sem identidade, objetificados por criminosos e suscetíveis à fetichização do leitor, elas servem também como uma crítica à violência contra as mulheres, à misoginia e, principalmente, à invisibilidade dessas vítimas.

Na favela de Inferno, as mulheres parecem ter poucas opções de ascensão social e de escapar da situação de dupla vulnerabilidade em que se encontram. Embora Alzira invista em aulas de computação para a filha, Carolaine, com a esperança de que ela escape às precariedades da favela por meio da educação, como nota Losada Soler, a menina não se mostra excepcional o suficiente para «escapar a la presión del medio» (2014: 23). Carolaine não é suficientemente inteligente e ativa para resistir às promessas de amor de homens mais velhos que tiram proveito da sua ingenuidade. Apaixonada por novelas e iludida pelo ideal de amor romântico, a menina se envolve com vários homens, engravida três vezes e, em todas elas, acaba criando o filho sozinha. Assim como Cledir, de 0 matador, Carolaine é um contraponto à figura da mulher autônoma e capaz de se libertar dos mecanismos de opressão patriarcal que sobre ela recaem, um

\footnotetext{
${ }^{24}$ No artigo $« \mathrm{O}$ contraponto do erotismo na literatura de autoria feminina de Luci Collin e Patrícia Melo» (2009), Daniele Santos associa a ação de Máiquel àquela do colonizador - que explora e conquista um território desconhecido -, enquanto a mulher se reduz a um corpo colonizado, objetificado, «materialização da dominação, (...) locus do exercício do poder» (2009: 64). Na descrição das relações sexuais de Máiquel e da violência sexual contra Cledir, observa-se uma associação entre o homem e a figura do colonizador, enquanto a mulher perde a sua condição de sujeito - ela é mero território ou animal irracional a ser domado. Ao mesmo tempo, reforça-se a violência dessas relações, ao associá-las a guerras e invasões, como se observa nos seguintes trechos: «Arlete a égua (...) eu, o cavaleiro, minha tropa de cavalos (...)» (Melo 1995: 09-10); «[m]ulheres gostam de tropas, cavalos, lanças, coisas que invadem e conquistam» (idem: 36$)$.
} 


\section{Bibliografia}

BENJAMIN, Walter (1938), «A Paris do Segundo Império», in Kothe, Flávio R. (org.) (1985), Walter Benjamin, São Paulo, Ática, pp. 43-122.

BERTENS, Hans/ D’haen, Theo (2001), Contemporary American Crime Fiction, Basingstoke, Palgrave.

BOOKER-MESANA, Corinne (2000), «Carmen», in Brunel, Pierre, Dicionário de mitos literários, trad. Carlos Sussekind et al., 3. a ed., Rio, Ed. José Olympio, pp. 146-150.

BOSI, Alfredo (2015), História Concisa da Literatura Brasileira, 50. e. ed., São Paulo, Cultrix.

BOYER, Régis (2000), «Mulheres viris», in Brunel, Pierre, Dicionário de mitos literários, trad. Carlos Sussekind et al., 3.ㄹ ed., Rio, Ed. José Olympio, pp. 744-746.

BUTLER, Judith (2013), Problemas de gênero: feminismo e subversão da identidade, trad. Renato Aguiar, 6. Ed., Rio de Janeiro, Civilização Brasileira [1990].

CARDOSO, Abílio Hernandez (2001), «Subjectividade, desejo e morte no 'film noir' americano», in Sampaio, Maria de Lurdes/Vilas-Boas, Gonçalo (orgs.), Crime, Detecção e Castigo: estudos sobre literatura policial, Porto, Granito, Editores e Livreiros, pp. 107-118.

CASTANHEIRA, Cláudia (2010), «Marcas da violência e jogos do poder no romance urbano de Patrícia Melo», Estudos de Literatura Brasileira Contemporânea, 36, julho-dezembro, pp. 241-250.

CAWELTI, John G. (1977), Adventure, Mystery, and Romance. Formula Stories as Art and Popular Culture, Chicago and London, The University of Chicago Press.

CEPEDA, Mariana (2017), Fogo-fátuo? Mulheres detetives na ficção policial brasileira (Dissertação de mestrado), Porto, Universidade do Porto. Disponível em: https://repositorio-aberto. up.pt/handle/10216/109345

CHANDLER, Raymond (1944), "A arte simples do assassínio», trad. Carlos Leite, in Sampaio, Maria de Lurdes/ Vilas-Boas, Gonçalo (orgs.) (2012), Ficção Policial: Antologia de Ensaios Teórico-Críticos, Porto, Instituto de Literatura Comparada Margarida Losa e Edições Afrontamento, pp. 59-74.

COMELLAS, Pere (2014), «Rubem Fonseca e o policial noir», Abriu: estudos de textualidade do Brasil, Galicia e Portugal, 3, pp. 51-69.

CONNELL, R. W. (2005), Masculinities, Berkeley, University of California Press.

CUDDON, J.A. (1998), «Crime Fiction», in The Penguin Dictionary of Literary Terms and Literary Theory, 4. ${ }^{\mathrm{a}}$ ed., London, Penguin Books, pp. 192-195.

DUNANT, Sarah (2000), «Body Language: a Study of Death and Gender in Crime Fiction», in Chernaik, Warren/ Swales, Martin/Vilain, Robert (eds.), The Art of Detective Fiction, New York, Palgrave Macmillan, pp. 10-20.

FARACO, Carlos Alberto (1998), «O matador de Patrícia Melo: uma abordagem bakhtiniana», Itinerários, Araraquara, 12.

HORSLEY, Lee (2009), Twentieth-Century Crime Fiction, New York, Oxford University Press. KLEIN, Kathleen Gregory (1995), «Habeas Corpus: Feminism and Detective Fiction», in 
Irons, Glenwood (ed.), Feminism in Women's Detective Fiction, Toronto, University of Toronto Press. [Edição do Kindle]. Disponível em: <https://www.amazon.com/>. (1995), «Introduction», in The Woman Detective: Gender \& Genre. Chicago, University of Illinois Press, pp. 1- 14 [1988].

LARSSON, Stieg (2010), The girl who kicked the hornet's nest (Millennium III), trad. Reg Keeland, London, Quercus Publishing.

LOSADA SOLER, Elena (2014), «Patrícia Melo. "Novela de favela” y novela criminal. Género(s)», Abriu, n. 3, pp. 9-27.

MACEDO, Ana Gabriela/ Amaral, Ana Luísa (orgs.) (2005), Dicionário da Crítica Feminista, Porto, Edições Afrontamento.

MELO, Patrícia (2010), Acqua toffana, Rio de Janeiro, Rocco [1994]. (1995), 0 matador, São Paulo, Companhia das Letras. (2010), Elogio da mentira, Rio de Janeiro, Rocco [1998]. (2003), Inferno, São Paulo, Planeta de Agostini [2000]. (2009), Valsa negra, São Paulo, Companhia das Letras [2003]. (2010), Mundo perdido, Rio de Janeiro, Rocco [2006]. (2008), Jonas, o copromanta, São Paulo, Companhia das Letras. (2010), Ladrão de cadáveres, Rio de Janeiro, Rocco. (2014), Fogo-fátuo, Rio de Janeiro, Rocco. (2017), Gog Magog, Rio de Janeiro, Rocco.

MEYERS, Diana Tietjens (1998), «Agency», in Jaggar, Alison M./ Young, Iris Marion (eds.), A Companion to Feminist Philosophy, Oxford, Blackwell Publishing, pp. 372-382.

MONTEIRO, Karla (2014), “"Romance policial é um papo sério”, afirma Patrícia Melo», Folha de S. Paulo [online]. 20 de dezembro. Disponível em: <https://www1.folha.uol. com.br/ilustrada/2014/12/1564996-romance-policial-e-um-papo-serio-afirma-patricia-melo.shtml>. Último acesso em: 09 de dezembro de 2018.

MUNT, Sally R. (1994), Murder by the Book?, London, Routledge.

OSTROM, Katherine Ann (2011), Literatura policial: gender, genre, and appropriation in Argentine and Brazilian hard-boiled crime fiction (Tese de doutoramento não publicada), Minneapolis, Universidade de Minnesota. Disponível em:<http://hdl.handle.net/11299/ 109824>. Último acesso em: 10 de dezembro de 2018.

PELLEGRINI, Tânia (2005), «Clear enigma: Brazilian crime fiction and urban violence», Centre for Brazilian Studies, University of Oxford, Working Paper number CBS 69-05. (2004), «No fio da navalha: literatura e violência no Brasil de hoje», Estudos de Literatura Brasileira Contemporânea, Brasília, 24, pp. 15-34.

PINHEIRO, Marta Passos (2012), «A alma encantadora das ruas: o cronista-flâneur no avesso da cidade», Revista Araticum, 5, 1, pp. 67-74.

PLAIN, Gill (2001), Twentieth-Century Crime Fiction: Gender, Sexuality and the Body, Edinburgh, Edinburgh University Press. 
PORTER, Dennis (1981), The Pursuit of crime: Art and Ideology in Detective Fiction, New Haven, Yale.

PRECIADO, Beatriz [Paul B.] (2011), «Multidões queer: notas para uma política dos anormais», Estudos feministas, v. 19, n. 1, jan./apr., trad. Cleiton Zóia Münchow e Viviane Teixeira Silveiras, pp. 11-20.

REIMÃO, Sandra (2005), Literatura Policial Brasileira. Rio de Janeiro, Jorge Zahar Ed. (2014), «Literatura policial brasileira: dificuldades e especificidades», Miscelânea, v. 16, jul.-dez., pp. 15-33.

RUBIN, Gayle (1999), «Thinking Sex: Notes for a Radical Theory of the Politics of Sexuality», in Parker, Richard/ Aggleton, Peter (ed.), Culture, Society and Sexuality: A Reader, New York, Routledge, pp. 143-178.

RZEPKA, Charles J. (2010), «Introduction: What is Crime Fiction?», in Rzepka, Charles J./ Horsley, Lee (eds), A Companion to Crime Fiction, Chichester, Wiley-Blackwell, pp. 1-9.

SAMPAIO, Maria de Lurdes (2007), «Cartografia para Problemas Terminológicos e Conceptuais», in História Crítica do Género Policial em Portugal (1870-1970): Transferências e Transfusões. (Tese de doutoramento), Porto, Ed. de Autora, pp. 27-52. (2011), «Millennium Trilogy: Eye for eye and the utopia of order in modern waste lands», Cross-Cultural Communication, vol. 7, n. 2, pp. 73-81. Disponível em: <http:// www.cscanada.net/index.php/ccc/article/view/j.ccc.1923670020110702.008/1784>. Último acesso em: 30 de dezembro de 2018.

SANTOS, Daniele (2009), «O contraponto do erotismo na literatura de autoria feminina de Luci Collin e Patrícia Melo», Cadernos do IL, Porto Alegre, 39, dezembro, pp. 59-70.

SCHØLLHAMMER, Karl Eric (2001), «From the Malandro (Rogue) to the Traficante (Drug Trafficker) - two constellations of violence in Brazilian culture», Diálogos Latinoamericanos, 4, 37-46. (2009), Ficção brasileira contemporânea, Rio de Janeiro, Civilização Brasileira.

SILVA, Pedro Puro Sasse da/ França, Júlio (2016), «Entrevista com Patrícia Melo», Revista Abusões, n.3,v.3, ano 2.Disponível em:<htp://dx.doi.org/10.12957/abusoes.2016.26220>. Último acesso em: 09 de dezembro de 2018.

SIMPSON, Philip (2010), «Noir and the Psycho Thriller», in Rzepka, Charles J./ Horsley, Lee (eds), A Companion to Crime Fiction, Chichester, Wiley-Blackwell, pp. 187-197.

TODOROV, Tzvetan (2006), «Tipologia do Romance Policial». in As Estruturas Narrativas, trad. Leyla Perrone-Moisés, 4. ㄹ ed., São Paulo, Perspectiva, p. 93-104 [1966].

WALTON, Priscilla/ Jones, Manina (2012), «Sim ou não? A problemática da narrativa de deteç̧ão feminina», trad. Marta Mascarenhas, in Sampaio, Maria de Lurdes/Vilas-Boas, Gonçalo (orgs.), Ficção Policial: Antologia de Ensaios Teórico-Críticos, Porto, Instituto de Literatura Comparada Margarida Losa e Edições Afrontamento, pp. 135-168. WOOLF, Virginia (1931), «Professions for Women», in Barrett, Michèle (ed.) (1996), Virginia Woolf on Women and Writing, Reading, Cox and Wyman, pp. 57-63. 


\section{Détection, Damage, and Resistance: On Sara Gran's Claire DeWitt's novels}

Paulo de Medeiros

University of Warwick

There's a nail in the door

And there's glass on the lawn

Tacks on the floor

And the TV is on

And I always sleep with my guns when you're gone

Shivaree, Goodnight Moon

Imagine, if you will, Nancy Drew meets Harry Potter, except only much, much darker and without any of the reassuring self-indulgent pieties so abundant in many detective novels, and one might have a feel for what Sara Gran's s Claire DeWitt series is about. From the beginning, with Claire DeWitt and the City of the Dead (2011) to the most recent, and third volume, The Infinite Blacktop (2018), Sara Gran has consistently portrayed a scathing view of American society that even though not completely bereft of hope, comes very close to it. Neither nostalgia nor simple utopian wishes for some sort of salvation, material or spiritual, ever gloss over the levels of devastation in collective as well as personal terms that characterize the books' universe. If there is anything that sustains Claire and enables her to survive in the direst circumstances, be it at the hands of her enemies or her own self-destructive fits, it is an implacable drive towards knowing the truth, remembering, and witnessing, supported by an unassailable belief in the power of detection.

Although Sara Gran also has published three other novels and there will be shared questions across them all, it is arguably in the Claire DeWitt series that Gran has more starkly moved towards pushing the rules of the genre and even subvert them. And while all three novels abound in metanarrative moments 
denoting a high level of reflection on the very condition of detective fiction today, they also are relentlessly grounded on the social conditions that the text at once represents and registers, embraces and exposes. There is a certain melancholy that never, ever, allows itself to fall into nostalgia, as the past and memory are crucial to all three novels; but there is also a sense of deep damage and hurt and a certain rage.

A rage that can be seen both in Claire's increasing self-destructiveness and her unfailing instinct to survive and seek a clear ethical path to her life, no matter how much she may stumble on all the broken ruins that for the most part have come to constitute both the physical as well as the moral landscape she, and we all with her, inhabit. In a recent interview when asked «What draws you to people with damaged histories?» Sara Gran did not hesitate to answer: «I don't think I've ever met anyone without some damage in their history» (Mystery People, 2018). It almost seems as if Gran was taking her cue from Theodor Adorno who subtitled his aphoristic and fragmentary book Minima Moralia, as Reflections on a Damaged Life and who, right in the dedication to Max Horkheimer, declared: «He who wishes to know the truth about life in its immediacy must scrutinize its estranged form, the objective powers that determine individual existence even in its most hidden recesses» (Adorno 1978: 15). This kind of aphoristic acuity is also liberally sprinkled throughout Gran's novels, as for instance in the «citations» from Détection, the book written by the master detective, Silette, which binds Claire with a select group of detectives as a kind of inheritance. But the sharp social critique is actually much more an effect of the narrative totality than what could appear to be a simple device or gimmick, in the phantasmatic figure of the past master. One goes with the other of course, yet they should not be confused, for doing so would merely veil the way the novels directly engage with the present even as they must always, repeatedly, return to the past.

There are all kinds of elements that bring the three books together, none more important, perhaps, than Détection, the book written by Jacques Silette, «the great French detective», from which Claire DeWitt liberally quotes as the book serves as a special kind of inheritance - both a method for her work and a kind of ethical guide for the various abysses she routinely confronts. Unless that is, one would think of the notion of absence, either in abstract terms, or rather in very concrete ones, as «embodied» in the various missing girls, whom Claire does not cease to look for. And perhaps Claire herself is one such missing girl; and absence in any case is also that which can be said to characterize Silette, 
who was dead before Claire found out about him when she «found» his book, and whose own daughter also went missing. But more on that later. Detection, of course, is central to crime fiction. One could say, with Foucault, that it is the emphasis on rational deducing that distinguished modern crime fiction from its various preceding forms such as the broadsides covering crime. As Foucault argues, modern literature of crime - in an earlier phase at any rate - replaces older narrative forms by radically changing the terms of engagement, displacing the role of violence and with it our view of the «criminal»: «We are far removed indeed from those accounts of the life and misdeeds of the criminal in which he admitted his crimes, and which recounted in detail the tortures of his execution: we have moved from the exposition of the facts or the confession to the slow process of discovery; from the execution to the investigation; from the physical confrontation to the intellectual struggle between criminal and investigator» (Foucault 1995: 69). By now of course, much has also changed so that the inversion observed by Foucault, whereby crime fiction would annul the possibility of viewing the criminal as a hero in the fashion of a Robin Hood, has returned, at least in part, or moved beyond any possibility of actually ever distinguishing between the "criminal» and the «hero», not just because the criminals to a great extent now occupy the very centre of power but because there are no longer any heroes.

Detective fiction is inevitably concerned with social issues and as such it relates, perhaps even more explicitly so than other kinds of fiction, with politics. As tempting as it might be to hold a neat separation line between detective novels, which would be on the left, and thrillers, which would tend to be on the right, as Val McDermid recently opined (McDermid 2015), that should be seen as a red herring. There is nothing intrinsic to the various modalities of crime fiction that would make them fall neatly along political lines. Having said that though, there could be a tendency for detective novels in general to offer some form of societal critique. The question immediately arising then has more to do with whether or not such a tendency is not after all yet another way for the system - both the patriarchal regime as well as the capitalist order intrinsic to western modernity - to co-opt what otherwise would be a genuine form of resistance, so as to better reinscribe prevalent norms. Nonetheless, in the case of Gran's detective fiction, one cannot but sense that the narratives deploy a full-fledged and even relentless critique of the status quo, started in The City of the Dead, deepened in Bohemian Highway (2013), and further explored in the recent The Infinite 
truth at any cost, whatever the truth may turn out to be, and especially the truth about one self. Binding it all, memory and loss and the sense of an imminent catastrophe. This is how Gran opens up The City of the Dead:

«IT'S MY UNCLE,» the man said on the phone. «He's lost. We lost him in the storm». «Lost?» I said. «You mean, he drowned?»

«No,» the man said, distressed. «Lost. I mean, yeah, he probably drowned. Probably dead. I haven’t heard from him or anything. I can’t imagine how he could still be alive».

«So what's the mystery?» I said.

A crow flew overhead as we talked. I was in Northern California, near Santa Rosa. I sat at a picnic table by a clump of redwoods. A blue jay squawked nearby. Crows used to be bad omens, but now they were so common that it was hard to say. Omens change. Signs shifts. Nothing is permanent. (Gran 2011:1)

On the one hand one could think that Gran simply starts her novel directly, with curt and brief dialogue, providing no answer (as yet) even to the nature of the mystery, just an assignation, a case, that Claire DeWitt will take but only after having a strange dream in the night, in which Silette appears to her on a house roof to escape, like her, the flooding waters: «I woke up coughing, spitting water out of my mouth. That morning I talked to my doctor about the dream. Then I called the man back. I took the case» (idem: 2). On the other hand, the short first chapter, with its sequence of a mysterious call about someone being lost, followed by Silette's equally mysterious advice, the irreality of it all, accentuated by how Claire wakes up spitting water and the seemingly rational decision to seek medical advice, could be seen as programmatic for the entire project represented so far in all three novels: there is the fundamental question of loss, the overriding presence of the dead in the figure of Silette, his uncomfortable emphasis on truth, the need to act morally, and bear witness: «Remember: you are the only hope for those that come after you» (ibidem). As should be clear we are already miles away from those characteristics Mandel pointed to as defining for the bourgeois novel. There is no reification of death, no formalized crime detection - actually quite its opposite: «'No one will save you’, Silette said from his rooftop. 'No one will come. You are alone in your search; no friend, no lover, no God from above will come to your aid. Your mysteries are yours alone’» (ibidem). Fredric Jameson’s remarks on Gabriel García Márquez' Hundred Years of Solitude, its seemingly «supernatural» events, and the infelici- 
ties of the label «magical realism» could be equally applied to Gran's novels: «No magic, no metaphor: just a bit of grit caught in transcendence, a materialist sublime (...)» (Jameson 2017). The water coming out of Claire's mouth that could be read as stressing the limits of verisimilitude, turns out to be just that bit of grit, and the nightmare that produces it is as real as it gets, the catastrophic flooding of New Orleans in the aftermath of Hurricane Katrina in August 2005.

City of the Dead highlights New Orleans, and the disaster that befell it, which exposed the almost total abandonment of its mostly poor and black population - the most recent US Census figures show that in 2018, even after a sharp decline in its black population since 2005, the percentage of Afro-American residents still was almost double that of white ones ( $59.7 \%$ vs. $34 \%$ ), while one quarter of the population still lived in poverty (United States Census Bureau, 2018). The catastrophe has been the subject of many novels, films, theatre plays, songs, and other representations. Gran's novel is not the only detective novel to feature the disaster prominently. Yet, its emphasis on exposing the truth and the fundamental importance of the truth, throughout all three novels, lends it an urgency that goes clearly beyond the topical as it turns on the very system that makes for such «unreal» reality. Or, to quote the well-know song «Minority Report», from Jay-Z: «Buses are on the way to take those people from New Orleans to Houston / They lyin' / People are dying at the convention center / Their government has failed them / George Bush doesn’t care about black people» (Jay-Z 2006). The first novel, however, already introduces many key components of Gran's writing strategies that the other two will repeatedly go on to develop. Certainly, some of this might be due to the very nature of running a series, in which readers are gratified by the repetition of what they recognize from previous instalments, and which simultaneously serves to introduce and bind new readers into the specific universe being deployed. Nonetheless in some cases more is at stake. That dream of drowning, for instance, resurfaces at the beginning of the second novel, The Bohemian Highway, only in darker tones as Claire not only dreams of standing atop a roof whilst surrounded by dark waters, she also dreams of watching her friend die: «I watched Lydia drown. / 'Help!' she screamed. (...) / But I didn't help. Instead I lit a cigarette and watched her drown. Then I put on a pair of thick black-rimmed glasses and watched her drown more closely» (Gran 2013: 7). And again, it is Silette's words that come to Claire in her dream, «'The client already knows the solution to his mystery, (...) But he doesn't want to know. He 
doesn't hire a detective to solve his mystery. He hires a detective to prove that his mystery can't be solved. This applies equally, of course, to the detective herself» (Gran 2013: 7). But does it? Silette's lines reappear again at the conclusion of The Infinite Blacktop just before Claire comes to the realization that happiness, what there might be of it in reality is not somewhere always in the far distance, but in the here and now. And Gran adds: «Silette also wrote, 'The road to the truth is crooked and disreputable. But the detective's devotion must be absolutely plumb straight, as sure as fast as American highway'»(Gran 2018: 290). Basically, Silette presents Claire - and readers - with a seeming paradox. On the one hand, the unmitigated critical outlook of the detective makes her question not only the motives of her client but her own as well, in a move that could be seen as doubly negative at best, even if not quite cynical. Yet, on the other hand, in order to be the kind of detective that SIlette advocates and Claire embodies, devotion to the truth must be absolute, so that the unrelenting questioning and self-questioning are presented as positive, rather than as just another form of negativity.

Silette's comments, and Gran's vision through them, are not at odds with each other at all. Rather than seeing them as somehow paradoxical one should see them as complementary - one following the other in a logic of detection that is really not so much geared towards producing evidence recognizable in a court of law, but at getting at the core of a rotten system and exposing its hidden, and not so hidden secrets. Writing on Raymond Chandler in The Detections of Totality Fredric Jameson has pointed to something similar, though not quite the same, at work in The Big Sleep: «But Chandler's picture of America has an intellectual content as well: it is the converse, the darker concrete reality, of an abstract intellectual illusion about the United States» (Jameson 2016: e26). This would also apply without further ado to Gran's writing. Jameson continues: «A kind of reverence attaches to the abstract, a disabused cynicism to the concrete. As in certain types of mental obsession and dissociation, Americans are able to observe local injustice, racism, corruption, educational incompetence with a practiced eye, while they continue to entertain boundless optimism as to the greatness of the country, taken as a whole» (idem: e27). And this too could apply to Silette's opinions. However, Claire does not align herself to such a vision. Although she certainly observes injustice, racism, and the profound inequality that marks American society or any capitalist society in general, her optimism - if one can call it that, at the conclusion of The Infinite Blacktop is nei- 
ther boundless nor tied to the supposed greatness of the country. Rather, it is anchored on finding a personal connection.

In that, as in many other respects, Claire DeWitt is not at all a kind of female inheritor of Phillipe Marlowe. Or she is, but only in the sense that as much as she may be tough as Marlowe was, she also turns him - and the whole masculinity pushed to the limits bit, the underlying misogyny of the genre in its initial phase - on its head. This, for instance, is how Rachel Watson, while pointing out how Fredric Jameson manages to avoid dealing with how women are reified by Chandler, has put it: «A reader less familiar with Chandler might get the mistaken impression that his fictional universe is not, in fact, obsessed with women: identifying them, capturing them, bedding them, controlling them, beating them, selling them, photographing them, avoiding them, instrumentalizing them, manipulating them, assessing them, pacifying them, observing them, missing them» (Watson 2018: 809). Should there be any doubts about the distance between Gran and Chadler on this, one would only have to contrast two small passages from Chandler's and Gran's work. Take the callous, pretended casualness in The Long Good-Bye, sometimes quoted as an advertisement for the book as a whole (for instance on the back cover of The Big Sleep): «Alcohol is like love', he said. The first kiss is magic, the second is intimate, the third is routine. After that you just take the girl's clothes off». One could almost imagine Gran having that or any other passage like it, of which there are plenty in Chandler, in mind when she wrote the following scene: Claire is on a night out with her friend Lydia whom she has introduced to Paul and the two are falling in love right in front of her eyes: «Watching people fall in love is like watching two trains rush toward each other at top speed, with no way to stop them» (Gran 2013: 6). Then she sees someone else she knows, Oliver, «a solid, mediocre PI who specialized in things like credit card fraud and embezzlement, the dull and damp shores of greed» (idem: 7). Oliver clearly has set his eyes on Lydia and this is how Claire deflates his gaze: «Oliver got that achingly sad look men sometimes get when they want a woman they can't have» (ibidem). Both Gran and Chandler endow their detectives with a rational, detached outlook, and a quick ability to draw on language to their advantage. Yet, there is no bravado in Claire's observations, no debasing or reifying of love, even as she presents it as something out of control. And whereas Chandler indulges in the cheap titillation of his audience with the sort of brutish reference to casual sex under the influence that one imagines might have passed for an affirmation of virility in the 1930s, 
As Maureen T. Reddy notes, «Race is ubiquitous and powerful in American crime fiction, as central in the genre as it is in American society; however, in fiction as in life, race matters are frequently denied, displaced, or otherwise so thoroughly disguised that many readers overlook them» (Reddy 2003:135). Claire not only is aware of racism, she also notes how she usually, if unwittingly, benefits from it: «In most cities I wouldn’t have worried about it much - we white ladies are pretty safe if we stick to our own neighborhoods, the beneficiaries of generations of racism whether we want it or not. But in New Orleans, I was pretty sure that even a white lady getting murdered didn't merit much attention from the cops» (Gran 2011: 90). And if «disaster capitalism», «slow violence», and the "color of disaster», all function on the basis of invisibility and forgetting, one of Claire DeWitt's, key concerns, an ontological imperative even, is the necessity to remember and the struggle against any kind of invisibility and erasure through forgetting. In City of the Dead Gran very specifically registers and renders witness to the devastation and how it endures, while directly linking the unending damage to the combined effects of race and poverty. One of the characters Claire meets, and who will become a key part of the various novels even if often absent himself, is Andray, an African American adolescent who in many regards is the embodiment of damage itself, an orphan of sorts, who has been through the various state institutions. Claire first comes across him by chance and then finds him out as her primary suspect as she is sifting through various files: «Andray's mother was the county and his father was the state. (...) As I was jogging the pages into a rectangle and sticking them into a folder I saw a picture of Andray Fairview and dropped the papers. It was the boy who'd peed on my truck. Suicide Boy» (Gran 2011: 44). Yet, instead of proving him to be the hardened murderer he seemed set up to be, Claire takes to him and will make him her assistant and, in a way, follower, just as she had been Constance Darling's charge and Constance was Silette's. As Silette wrote, «There are no coincidences», only «mysteries that haven't been solved» (idem: 44). And one of those is the fact that Andray has his own copy of Détection, «the U.K. paperback, [with on its cover] a black bird in flight» (idem: 62).

Damage is overwhelmingly material but also personal, highly visible but also hidden and running deep within people. Perhaps no other work quite captures this as the photographs taken by Mario Tamas directly after the Hurricane, and subsequently in the years since as he kept returning to the city, documenting both its resilience as well as the appalling way in which, as already remarked, 
for all purposes and intents the people who suffered the most were simply written off and forgotten. Indeed, it is perhaps not so much the spectacular images of the utter destruction of the city - think of streets both completely flooded and with the buildings still engulfed in flames - but the quieter ones - such as that of the little 18 month year old girl asleep on a torn old mattress completely covered in black mould in her parent's leaking FEMA (Federal Emergency Management Agency) trailer - that best capture the kind of damage Gran registered (Tama 2010). Andray was damaged even before being born, as his mother was a heroin addict. Claire pours through his file and adds all forms of damage, from the early abandonment to state institutions, the sexual abuse in foster homes, the continuous arrests, down even to the very lack of government training programs designed to make their charges more amenable to society's bourgeois, capitalist norms, «be obedient to a boss and a wife instead of a pimp or a gang leader» (Gran 2011: 63). It is not just the fact that Andray owns a copy of Détection that draws Claire to him. Even though their backgrounds are quite different, there are secret and not so secret affinities that bind them. The one secret connection which will be revealed as Claire manages to find the truth about Andray's possible involvement in Vic's disappearance that she had been initially hired to solve, is that Andray had been drawn to Détection while visiting at Constance Darling's house - Constance who had been Sillette's disciple and whose became Claire's mentor. Entering the house's library, one of the few memories Claire herself cherishes, Andray, much like Claire, had felt the book's calling. The open connection though is at least equally important and that is their experience of witnessing the death of people they knew, and especially death by drowning. As Claire and Andray sit in her truck, Andray mentions seeing the floating corpses after the flood, that just would not go away and asks Claire if she had ever seen any. Claire answers yes as she is reminded of the girl whose body she had found once, and who looked just like her missing friend Tracy, with whom she had initially discovered a copy of Silette's book in the usually locked up south wing of her parent’s old Brooklyn house: «'Yeah', I said. I remembered the girl in the bay. She'd drowned trying to go home. Trying to swim. She froze instead. It's an ugly way to die» (Gran 2011: 94). There is a deeply personal side to the question of drowning that is linked to Tracy's disappearance. But there is much more to it, as Claire notes: «Some people, I saw, had drowned right away. And some people were drowning in slow motion, drowning a little bit at a time, and would be drowning for years. And some people, like Mick, had always 
been drowning. They just hadn't known what to call it until now» (idem: 77). In a way it is as if drowning becomes a kind of original trauma that keeps not only being remembered, but also re-enacted, throughout the novels as it assumes collective proportions. As such it both echoes the specific catastrophe and, not unlike Nixon's notion of slow violence, goes beyond it.

More importantly though, is the way in which Gran deals with the whole question of memory, legacy, and inheritance. Memory, forgetting and remembering, are always present in one way or another in all three novels, from the very beginning of the first one to the conclusion of the last, that both goes back to the original trauma, Tracy's disappearance, and signifies a return, or at least the possibility of a return - even if at the very moment of ending Claire and Claude are still on that infinite blacktop, driving «down the long dark road toward home» (Gran 2018: 290). «Remember, remember» is the self-directed imperative that keeps being voiced throughout the Infinite Blacktop, the one novel of the three in which the process of remembering and trying to piece together loose scraps of memory to hold on to a sense of self, indeed to survive, is most intense. Claire must make an effort to remember what happened to her as she barely survives the various attempts at killing her and she also must try to remember her childhood and early adolescence to try to understand what she has never been able to deal with, Tracy's disappearance on the one hand, but also the absolute lack of interest the world has towards all of those other girls and women whose violent deaths are as if erased, their pain not just forgotten but not even acknowledged. Even if there is always a certain rage in the two preceding novels, the last does not hold back:

I knew the girl in the water. She was a year younger than me. (...) We laid it out for the NYPD detective (...) we realized it would be many, many dawns before anyone cared about the girl in the canal. It would be until the earth wilted, until time stopped, until the sun burned itself into a handful of dust, until Judgment Day came and we were raised from our coffins and canals and black-alleys and bedrooms, until we were called up to heaven and then maybe, someone would care about the fucking girl in the canal. (idem: 11-12)

This kind of rage comes from a deep sense of grief that is not limited to any one kind of injustice or cruelty but directed at a system that depends on profound inequality and the denial of even the most basic safeguards of humanity as it relegates large swaths of the population to abject conditions indiscrimi- 
nately: «The lines of undesirability were easily blurred, as I knew all too well. Start off as just poor and it was pretty easy to get to homeless and addict. Start off addicted and it was a short walk to poor» (idem: 188). Early crime fiction, such as that of Raymond Chandler had already clearly registered what might be seen as the apex of modern capitalism in the early part of the twentieth century; after all Marlowe could «always hear the sound of money» (Chandler 2011: 80-81). Far from simply registering the conditions of life in late capitalism, however, Gran refuses any kind of resignation, cynical or otherwise, and incorporation into that system. There is no appeal to utopia, no holding on to the promise of a less cruel future, and certainly no nostalgia for any kind of better past that never was - Claire's past for the most part is a haunted and haunting landscape and perhaps that is why she had to leave her native Brooklyn: «I hated Brooklyn-hated its filthy streets, its dying trees, its rows of colorless brownstones, its attached houses that suffocated you, and most of all hated the rich yuppies who were taking it over neighborhood by neighborhood, murdering what little was good»(Gran 2011: 191). As Claire goes on to explain, «It used to be a miserable, poor place where people talked to each other. Now it was a miserable, expensive place where people ignored anyone outside their clan. (...) I didn't leave home. Home left me, block by block» (idem: 191). Besides the various traumas Claire experienced, foremost the drowning of the girl who was trying to escape a life of constant abuse at home, and Tracy's unexplainable disappearance, what Claire also reacts against is precisely the very system that not only displaces those who are most vulnerable, but does so insidiously, slowly, but surely, all in the name of individualism and sheer greed. In the twenty-first century, in spite of, or even because of, some real progress having made after World War II and the Civil Rights Movement, the conditions of late capital and neoliberalism have only aggravated the intrinsic inequality and racism that never ceased being constitutive of Western societies. By now, of course, even that might already be a chapter of recent history. There is a new escalation in the threats to any form of collectivity, and even to the norms of liberal, bourgeois, democracy, as Wendy Brown has argued when considering that today's 'intensifying nihilism (...) challenges truth and transforms traditional morality into weapons of political battle' (Brown 2019: 7). Resisting against this rise in nihilism, Gran posits Claire's obsession with knowing the truth, however unsavory and painful it might be, as she takes solace in Salette's Détection: «Because this, for better or worse, is exactly where the truth lies - at the intersection of the 
forgotten and the ignored, in the neighborhood of all we have tried to forget» (Gran 2011: 241).

Silette would appear to occupy a hallowed place in the imaginary of the Claire DeWitt books, as Claire keeps drawing on his book, Détection, for inspiration and guidance. And yet, Silette himself, for all his maxims, could not prevent his daughter from disappearing and could not find her. Loss affects him, one might say, as deeply as it affects Claire and others throughout the three novels. Silette and his Détection fulfill a number of roles. He is at once the patriarchal figure, the one who makes the rules for how to become a proper detective, and he is duly revered by Claire as the origin of the world she chose, the vocation she could not but follow. At the same time of course, he is not only dead but did not manage to solve the one mystery that mattered the most to him - that of his daughter's disappearance, which also occasioned yet another disappearance: «Twenty-odd years after he wrote Détection, in his last interview, Silette was asked his own question: What had disappeared when his daughter vanished? 'My happiness', he answered. Silette never spoke publicly again» (Gran 2011: 19). As such, Silette is both the exemplary model of how to operate as a detective and its most obvious failure as loss gives rise to more loss. So much for any simple legacy. Furthermore, Silette, whom she never met, is certainly not the only marking figure for Claire. The other, we must keep in mind, is Constance Darling, Silette's immediate disciple and more. As Claire explains: «I'd moved to New Orleans in 1994 to work for Constance Darling, the detective. She was a former student of Silette's; student, friend, collaborator, lover. I left New Orleans when she was murdered nearly three years later» (idem: 18). It is not quite possible to say whether Constance is more or less influential for Claire than Silette's book; but it is Constance, whom Claire misses. Whereas Constance provides a more direct model as her direct teacher, it is still the figure of Silette that haunts her. In a significant study of the genre, Twentieth-Century Crime Fiction: Gender, Sexuality and the Body, Gill Plain drew on Julia Kristeva's notion of the abject and applied it. For Plain, «[c]rime fiction in general, and detective fiction in particular, is about confronting and taming the monstrous. It is a literature of containment, a narrative that 'makes safe» (Plain 2001: 3). However different the ideological presuppositions of Plain and Mandel might have been, they seem to coincide in this view of detective fiction as serving to reinforce the very order it would appear to question, if not downright subvert. To a certain extent of course that might still apply to the work of Sara Gran. For all the corruption, 
inequality, treachery, and treason that Claire exposes, for all the violence she witnesses and barely escapes from, in the end it seems she is fine, isn't she, even driving down the highway again, not alone but next to Claude, having found some happiness, however temporary, and basking in the revelation of that evidence: «I felt light, and like maybe beauty was possible, even - especially - under the bright light of the truth» (Gran 2018: 290). Yet, perhaps we should take a page from Claire's - or is it Silette's - book and ask ourselves that fateful question, whether the client, as well as the detective, which is to say the critic as well, does not already know «the solution to his mystery» only hiring «a detective to prove that his mystery can't be solved» (idem: 290). Because perhaps Gran's fiction plays the game so well as to lead us to believe that after all it is just yet another way for containing the lies, the systemic violence, our own abandonment and the consummate loss of any kind of truth in our late capitalist societies. Or does it manage to still leave us unsettled, any prospect at appeasement, at letting ourselves be cuddled by our own false consciousness masquerading for critical sharpness, as temporary as Claire's well-deserved moments of happiness at the end? Self-critique though, is as relentless a drive in Claire DeWitt's universe, as we can also read in Détection: «The detective who thinks she’s found the truth is as wrong as the detective who never managed to look for it at all» (idem: 32). Inasmuch as it functions as an antidote to the rising nihilism, the obsession with truth, far from being an intellectual panacea, is its most forceful form of resistance.

\section{Works Cited}

ADORNO, Theodor W. (1978), Minima Moralia: Reflections on a Damaged Life, London, Verso. BROWN, Wendy (2019), In the Ruins of Neoliberalism: The Rise of Antidemocratic Politics in the West, New York, Columbia University Press.

CHANDLER, Raymond [1939] (2011), The Big Sleep, London, Penguin.

DYSON, Michael Eric (2006), Come Hell or High Water: Hurricane Katrina and the Color of Disaster, New York, Basic Civitas.

FOUCAULT, Michel (1995), Discipline and Punish: The Birth of the Prison, Second ed. Alan Sheridan, Transl. New York, Vintage.

GRAN, Sara (2011), Claire DeWitt and the City of the Dead, Boston and New York, Houghton Mifflin Harcourt. 
(2013), Claire DeWitt and the Bohemian Highway, Boston and New York, Houghton Mifflin Harcourt.

(2018), The Infinite Blacktop, New York, Atria Books, London, Faber and Faber.

JAMESON, Fredric (2016), Raymond Chandler: The Detections of Totality, London, Verso. (2017), «No Magic, No Metaphor», London Book Review 39.12. 15 June, 21-32. https:// www.lrb.co.uk/the-paper/v39/n12/fredric-jameson/no-magic-no-metaphor. Accessed 8 March 2020.

JAY-Z (2006), «Minority Report», Kingdom Come, Roc-a-Fella and Def Jam.

KLEIN, Naomi (2007), The Shock Doctrine: The Rise of Disaster Capitalism, New York, Metropolitan Books.

LÖWY, Michael (2007), «The Current of Critical Irrealism: 'A Moonlit Enchanted Light'». Adventures in Realism, Ed. Matthew Beaumont, Oxford, Wiley, pp. 193-206.

MANDEL, Ernest (1984), Delightful Murder: A Social History of the Crime Story, Minneapolis, University of Minnesota Press.

McDERMID, Val (2015), «Why Crime Fiction Is Leftwing and Thrillers Are Rightwing», Guardian. 1 April. https://www.theguardian.com/books/booksblog/2015/apr/01/whycrime-fiction-is-leftwing-and-thrillers-are-rightwing. Accessed 8 March 2020.

MUNT, Sally R. (1994), Murder by the Book? Feminism and the Crime Novel, London and New York, Routledge.

NIXON, Rob (2011), Slow Violence and the Environmentalism of the Poor, Cambridge, Mass., Harvard University Press.

PLAIN, Gill (2001), Twentieth-Century Crime Fiction: Gender, Sexuality and the Body, Edinburgh, Edinburgh University Press.

REDDY, Maureen T. (2003), «Race and American Crime Fiction», The Cambridge Companion to Crime Fiction, ed. Martin Priestman, Cambridge, Cambridge University Press, 135-147.

SHIVAREE (1999), «Goodnight Moon», I Oughtta Give You A Shot In The Head For Making Me Live In This Dump, Odeon Records and Capitol Records.

TAMA, Mario (2010), Coming Back: New Orleans Resurgent, New York, Umbrage.

United States Census Bureau, «Quick Facts, New Orleans City, Population estimates, July 1, 2018, (V2018)». https://www.census.gov/quickfacts/fact/table/ neworleanscitylouisiana/PST045218\#PST045218. Accessed 8 March 2020.

WATSON, Rachel (2018), «Frederic Jameson's Raymond Chandler: The Detections of Totality (2016)», Critical Inquiry, 44.4, 809-811. 


\section{Notas biobliográficas sobre os/as colaboradores/as}

Adriana BEBIANO é Professora Auxiliar da Faculdade de Letras da Universidade de Coimbra, diretora do Doutoramento em Estudos Feministas e Presidente do Conselho Científico do Centro de Estudos Socais da Universidade de Coimbra. Leciona em Literatura Inglesa, Estudos Artísticos e Estudos Feministas e tem publicado sobre ficção contemporânea de autoria feminina, estudos irlandeses e teoria feminista. Destacam-se os artigos «Speak Truth to Power: Representation and Discipline in Feminist Studies» (Lisboa, 2018); «Meninas, senhoras e galdérias: representações das mulheres em língua portuguesa» (Coimbra, 2017); «Engendering the Nation: Irish Women and Nationalism», (S. Paulo: 2011); e «Mad, Bad, and Dangerous to know: The Stories of Chicago May and Eliza Lynch» (Frankfurt: 2011). Com Maria Irene Ramalho, organizou o número 89 da Revista Crítica de Ciências Sociais, «Estudos Feministas e Cidadania Plena» (2009), e publicou, em 2018, "A Revista Crítica de Ciências Sociais e o Feminismo (1978-2017)», no número especial comemorativo dos 40 anos da $R C C S$.

Carlos Jorge Figueiredo JORGE é Professor Emérito da Universidade de Évora; jubilado em 2014 como Professor Associado com Agregação na Universidade de Évora, onde ensinou Literatura Comparada e Teoria da Literatura. Últimos livros publicados: Moradas, aparições e Intrigas, 2017, Apenas Livros, Lisboa; 2012 - Plágio - Propriedade e Apropriação em Eça, Zola e Outros..., Apenas Livros, Lisboa; 2011 - Histórias, Imagens e Letras - Literatura e Cinema numa Perspectiva Comparatista, Apenas Livros, Lisboa. Grande parte da bibliografia produzida encontra-se no site ACADEMIA.EDU, em https://uevora.academia.edu/CarlosJorgeFigueiredoJorge

Duarte PINHEIRO é, desde 2015, docente do Camões, Instituto da Cooperação e da Língua I.P. no Departamento de Espanhol e Português da Universidade da Califórnia, Berkeley; e ainda diretor do programa de Português na Universidade Estadual de São José, desde 2016. Doutorado pela Universidade Fernando Pessoa com a dissertação Além-sombras: Ana Teresa Pereira, a sua investigação revela particular interesse pela ficção policial e poesia contemporânea de expressão portuguesa. Vive em Sacramento, Califórnia. 
Elena LOSADA SOLER (Barcelona 1958) é Professora de Literatura Portuguesa na Universidade de Barcelona onde se doutorou em 1986 com uma tese sobre a recepção em Espanha da obra de Eça de Queirós. A sua área de investigação principal é a literatura portuguesa do século XIX e nesse âmbito publicou textos sobre Antero de Quental, Eça de Queirós, Camilo Castelo Branco e Cesário Verde. Fez parte da equipa dirigida pelo Prof. Carlos Reis para a elaboração da edição crítica da obra de Eça de Queirós. Neste projeto publicou a edição crítica d'A Ilustre Casa de Ramires e Textos de Imprensa V. Revista Moderna. Trabalha também na área dos estudos de género e a literatura de mulher, na literatura espanhola e nas literaturas lusófonas, especialmente sobre a escritora brasileira Clarice Lispector, grande parte da obra da qual traduziu para espanhol. Desde 2011, a sua pesquisa tem-se centrado na ficção criminal escrita por mulheres e foi investigadora principal de dois projetos com financiamento oficial: «Mujeres y novela criminal en España (1975-2010): autoras, figuras de poder, víctimas y criminales (MUNCE)» (FEM201122870, 2012-2014), e «Víctimas y agresoras. Representaciones de la violencia en la narrativa criminal escrita por mujeres (VANACEM)» (FEM2014-55057-P, 2015-2018).

Gonçalo VILAS-BOAS é professor catedrático jubilado, na área de literatura de expressão alemã na Faculdade de Letras da Universidade do Porto. Foi Coordenador Científico do Instituto de Literatura Comparada Margarida Losa. Escreveu vários artigos sobre autores de língua alemã, como Robert Walser, Franz Kafka, Annemarie Schwarzenbach, Max Frisch, Friedrich Dürrenmatt, Patrick Süskind, Erika e Klaus Mann, Hugo Loetscher, Christian Kracht, Lukas Bärfuss, Peter Stamm, Antje Rávic Strubel. As suas áreas de investigação têm sido a literatura suíça de expressão alemã desde 1900, o labirinto minóico, a literatura de viagens a partir de 1900 centrando-se no Irão e o Médio Oriente em textos europeus escritos em diferentes línguas. Tem também trabalhado sobre o romance policial de língua alemã. Tem, igualmente, estudado o teatro sueco, sobretudo August Strindberg. Publicou, entre outros, vários livros com textos de e sobre Annemarie Schwarzenbach. Organizou uma antologia do conto suíço (Histórias de Encontros e desencontros, Porto, Edições Afrontamento, 1991) e outra do conto nórdico (A Luz que Vem do Norte, Porto, Edições Afrontamento, 2004). Editou o livro Literatura Alemã III, da Universidade Aberta. Mais recentemente publicou Viagens pela Literatura Suíça. Ensaios.

Jochen VOGT doutorou-se em 1968 na Universidade de Bochum. Desde 1973 foi docente na Universidade de Essen, na área da literatura alemã. Especializou-se em literatura alemã e europeia do século XX, assim como em questões de narratologia e de teoria da literatura e também em didáctica. Dentro dos estudos literários investigou, entre outras vertentes o romance criminal como género literário. De entre as suas numerosas publicações destacam-se Aspekte erzählender Prosa, Der Kriminalroman. Poetik. Theorie. Gesschichte, Medien Morde. Krimis intermedial, Knapp vorbei, Erinnerung, Schuld und Neubeginn: deutsche Literatur im Schatten von Weltkrieg und Holocaust. 
Kirsten REIMERS ist é leitora na editora Campus, mas trabalha também para outras editoras, organizando seminários, conferências e escrevendo recensões. É responsável pela página na internet Krimidetektor, seguindo de perto a produção mundial de literatura policial, sobretudo a publicada em língua alemã. Desde 2019, pertence ao júri do Deutschen Krimi Preis.

Maria de Lurdes Morgado SAMPAIO é Professora Auxiliar da Faculdade de Letras da Universidade do Porto e investigadora do Instituto de Literatura Comparada Margarida Losa. Mestrado em Estudos Anglo-Americanos (Univ. Coimbra) e doutoramento em Literatura na UP. A sua atividade crítica tem contemplado autores vários desde José Marmelo e Silva a José Craveirinha (em comunicações orais não publicadas) a muitos outros na base de ensaios publicados em revistas nacionais e internacionais (Ezra Pound, Eça de Queirós, Fernando Pessoa, José Cardoso Pires, Julieta Monginho, Regina Guimarães, Mia Couto, etc.). Tem privilegiado as relações entre «cânone» e «não-cânone» no sistema literário português, as margens, a censura, a tradução e relações interculturais. Publicações seleccionadas: Aventuras Literárias de Eça de Queirós e Ramalho Ortigão (2005), «Ezra Pound and Fernando Pessoa with T.S. Eliot in-between», in Portuguese Modernisms (2011); co-autora, com Patricia Odber de Baubeta e Margarida Vale de Gato: The Anthology in Portugal: Literature, Translation and the Margins (2014); co-editora, com Gonçalo Vilas Boas, de Ficção Policial: antologia de ensaios teórico-críticos (2013) e com Marinela Freitas, Ana Luísa Amaral e Alexandra Moreira, Legados e Heranças: Políticas (Inter)Sexuais Hoje. Edições Afrontamento/ILCML, 2019. Colaborou na edição anotada de Novas Cartas Portuguesas (Dom Quixote, 2010).

Maria João FALCÃO nasceu em Portalegre. É licenciada em Filologia Românica, pela Universidade Clássica de Lisboa. Foi professora do ensino secundário. Viveu em Roma e trabalhou, como leitora convidada, no Departamento de Línguas Estrangeiras da Universidade de Roma, La Sapienza, como assistente da Professora Luciana Stegagno-Picchio. Além de Itália, viveu em São Tomé e Príncipe, Israel e Marrocos. Nos anos 80, publicou alguns contos na revista Peregrinação e, nos anos 90, na revista cultural Batê Mom, em São Tomé e Príncipe. Em 2006, ainda em São Tomé, sai o livro de contos, Ilhas na Bruma - obra editado pela UNEAS (União dos Escritores e Artistas São-tomenses) com o apoio da Fundação Gulbenkian. Em 2009, publicou, em edição de autor, dois livros de contos: Recordações da Tha, sobre São Tomé, e Histórias da casa Amarela, recordações da infância. Em Janeiro de 2019, publicou o livro de contos autobiográfico, Os figos de Setembro e outras histórias, edições RG. Tem várias obras inéditas, inclusive dois romances policiais, e outro livro de contos sobre a Ilha de São Tomé, a sair brevemente. Desde Abril de 2014, tem um blogue cultural-literário que se chama «O Falcão de Jade».

Mariana CEPEDA é graduada em Comunicação Social, pela Universidade Federal de Minas Gerais, pós-graduada em Projetos Editoriais Impressos e Multimídia, pelo Centro Universitário UNA, e é mestre em Estudos Literários, Culturais e Interartes (MELCI), pela Universidade do Porto. Em sua dissertação de mestrado, Fogo-fátuo? Mulheres detetives na ficção 
policial brasileira (2017), estudou a participação das mulheres na literatura policial no Brasil, como autoras e personagens, com destaque para as obras Os seios de Pandora (1998), de Sonia Coutinho, No fio da noite (2001), de Ana Teresa Jardim, e Fogo-fátuo (2014), de Patrícia Melo. Publicou os artigos «O céu de Suely: expressão corporal, performatividade de gênero e mulheres possíveis» (2016) e «De olhos bem abertos: uma leitura do livro e do filme ‘A Costa dos Murmúrios' em diálogo com os Estudos Feministas» (2016). Atualmente, atua como tradutora e redatora.

Paulo de MEDEIROS é professor catedrático de Literatura Comparada na Universidade de Warwick, Reino Unido. Estudou nas universidades de Lisboa, Freiburg e Massachusetts (Boston e Amherst). De 1998 a 2013 foi professor catedrático na Universidade de Utrecht, Holanda, onde dirigiu o Departamento de Estudos Portugueses, tendo sido professor convidado em várias universidades em Portugal, Inglaterra, Brasil, e Estados Unidos. Em 2011-2012 foi Keeley Fellow em Wadham College, Oxford, e é também honorary fellow do Instituto de Investigação em Línguas Modernas da Universidade de Londres. Presidiu à American Portuguese Studies Association em 2013 e 2014. Tem publicado variadamente sobre teoria literária, autores de língua portuguesa, pós-colonialismo, fotografia e cinema. Em 2013 publicou Pessoa's Geometry of the Abyss: Modernity and the Book of Disquiet (Oxford: Legenda).

Sara KÄRRHOLM é docente na Universidade de Lund em Estudos de Media e Culturas Digitais. Nos seus diferentes projectos combinou várias questões ligadas às estéticas literárias, ao valor literário e o modo como a literatura interage com a sociedade em geral. Entre outras coisas tem investigado as questões de género e como este é influenciado pelas normas da sociedade. O foco principal tem sido o romance policial, mas também tem estudado a literatura infanto-juvenil e outros géneros literários populares. Investiga também como é que os géneros feminino e masculino agem no mercado livreiro e como são promovidos nos diferentes canais de marketing tradicionais ou digitais. A sua investigação tem sempre em conta o campo interdisciplinar dos estudos culturais. Tem também pesquisado a história dos media e das políticas de publicação. Tem publicado inúmeros artigos em revistas e livros, quer na Suécia quer no estrangeiro. Actualmente está integrada nos projectos: «Brott lönar sig. Kriminallitteraturförfattaren som föregångare på den svenska bokmarknaden ", "Cultures of Consumption», «Digital Cultures Research Node», «Forskningsnoden för studier i analog kultur», tendo estado ligado a vários outros projectos, entretanto acabados.

Virginia SPYRATOU estudou Língua e Literatura alemãs, com foco nos séculos XIX e XX na Universidade Nacional Capodistriana de Atenas. Estudou também teoria literária feminina, estudos de género, literatura e cinema. Doutorou-se em 2007. Desde 2006, é professora do ensino secundário na Grécia. 




Em Cherchez les femmes: estudos de literatura policial, o género foi durante décadas dominado por autores masculinos, pois o ofício de detetive não era considerado apto para as mulheres (....). As mulheres não tinham grande espaço fora do lar e não foram muitas as que, ao longo do século XX, conquistaram lugares importantes. Com a evolução dos direitos das mulheres, a situação foi-se modificando lentamente. Note-se que o público, masculino e feminino, tinha continuado a dar preferência aos heróis masculinos. Mas foi sobretudo a partir dos anos 80 do século XX que as mulheres conquistaram lugares de relevância na deteção, primeiro, como private eye, depois, integradas em diferentes corpos da polícia, sendo, por vezes, investidas de papéis de chefia no grupo. Este facto representou uma quebra no domínio da perspetiva masculina, surgindo diferentes subgéneros e combinatórias diversificadas. (...) Nos ensaios reunidos neste volume pretende-se olhar para a história de algumas literaturas 'de crime' (ou «policiais») e para algumas escritoras de diferentes países e zonas linguísticas, mas também de escritores onde a figuração das mulheres seja relevante. 